\title{
SEISMIC ANALYSIS OF REINFORCED CONCRETE BUILDINGS IN THE 1931 HAWKE'S BAY EARTHQUAKE
}

by

Geert van de Vorstenbosch

\author{
A thesis \\ submitted to the Victoria University of Wellington \\ in partial fulfilment of the \\ requirements for the degree of \\ Master of Building Science
}

Victoria University of Wellington

2000 


\section{Abstract}

This thesis examines current earthquake engineering theory and practice regarding Earthquake Risk Buildings to determine if the seismic performance of reinforced concrete buildings is currently underestimated. The types of structural systems investigated are:

- Reinforced Concrete Structural Walls

- Unreinforced Brick Masonry (URM) Infill Frames

- Reinforced Concrete Moment Resisting Frames

Buildings with the above systems that survived the February 31931 Hawke's Bay earthquake and are still in existence are the set of buildings studied. As much structural information as possible was found for a total of 25 buildings which are analysed in two orthogonal directions. The calculated probable shear and bending strength of each structural member (at ground floor) is compared with the actual estimated seismic shear force and bending moment applied during the earthquake. The restoring moments of structural walls are compared to the calculated overturning moments. The results are expressed as ratios of the above forces and moments of each member.

The thesis shows that current theory expects most buildings to fail during both the 1931 Hawke's Bay earthquake and the Code design earthquake but most performed very well with no structural damage. The thesis examines the possible causes of underestimation of seismic performance by current earthquake engineering theory and practice, and makes recommendations for refining and improving practice. Recommendations are also made for further research to establish a simple assessment method for analysing other similar buildings based on the plan area of reinforced concrete structural elements alone. 


\section{Acknowledgements}

I would like to express my heartfelt appreciation to my Supervisor, Andrew Charleson (Senior Lecturer, School of Architecture, Victoria University of Wellington), for his constant moral, personal and professional support for the duration of this thesis. His continued input and insight has given rise to much valuable information. As my mentor, Andrew has always fed his enthusiasm for earthquake engineering through me into this report. Thanks Andrew.

I give a special mention of thanks to my External Supervisor, David Dowrick (Senior Research Engineer, Institute of Geological and Nuclear Sciences), who has researched the effects of the 1931 Hawke's Bay earthquake extensively. David originally gave me the topic (and a job) for this thesis and provided me with the necessary resources initially to collect much of the building data. His many contacts around the country have proved to be very helpful indeed. His previous research on the 1931 Hawke's Bay earthquake has provided this thesis with much of the background reading material and analysis data. Thanks David.

My thanks go out to everyone else who has contributed to this task. This includes my friends, close and abroad, my family for always believing in me, and especially Susan for sticking with me through all of this. You have all made me a better person.

Special thanks go out to my dearest friend Russell for proofreading this thesis.

Finally, thanks to all the other contributors: building owners, building occupiers, Staff at the School of Architecture and the other Postgraduates there, and staff at Hastings District Council and Napier City Council for helping me complete this...you know who you are. 


\section{Contents}

Abstract

Acknowledgements

Contents

List of Illustrations

Chapter 1 - Introduction

Introduction

The Earthquake

The Buildings

The Structural Systems

Chapter 2 - Literature Review

Introduction

Site Soil Classes

Building Data

Earthquake Risk Buildings

Recorded Damage To Buildings 8

Infill Frame Wall Performance

Infill Panel Failure Modes

Approximate Assessment Procedure

Chapter 3 - Methodology

Introduction

Building Selection Criteria

Fieldwork 
Research Method

Pilot Analysis

Phase 1 Peak Structural Response

Phase 2 Calculations of Forces on Members

Phase 3 Calculations of Probable Member Strength

Phase 4 Comparison of Probable Member Strength

Phase 5 Assessment Method for Other Buildings

Chapter 4 - Pilot Analysis Results

Building Descriptions

Results

Conclusions

Chapter 5 - Final Analysis: Building Descriptions and Results

Methodist Church Hall

Hawke's Bay County Council

Public Trust Office (Napier)

Murdoch (JH) Bakery

Dalgety \& Co

Ancient Order of Foresters

Union Hotel

Harston's Concert Hall

Bennett Building

Parker Chambers

Williams Buildings (I)

Williams Buildings (II)

Richardson \& Co

Howe Bros

West (JS) \& Co

Poppelwells

Dominion Buildings

Public Trust Office (Hastings)

Rainbow, Hobbs and Nesbitt 
Hawke's Bay Jockey Club Racecourse -Steward Stand

Hawke's Bay Farmer's Co-Operative

Webber's Buildings

Villa d'Este

Chapter 6 - Analysis of Results

Introduction

Structural Walls and Infill Walls

Overturning of Walls

Shear Strength of Walls

Rocking of Walls as a Mechanism to Prevent Shear Failure

Infill Panel Shear Strength

Moment Resisting Frames

Shear and Bending Strength

Approximate Assessment Procedure

Chapter 7 - Conclusions and Recommendations

Introduction

Damage to Buildings

Reinforced Concrete Walls

URM Infill Frame Walls

Moment Resisting Frames

Approximate Assessment Procedure

Recommendations

Appendix A - Response Spectra of Ground Classes A, B, and C 116

Appendix B - Results Table

Appendix C - Summary Table of Damage Records and Vertical Reinforced

Concrete Structure 


\section{List of Illustrations}

Figure 1 Map showing location of Hastings and Napier and the rupture plane for $M_{s} 7.83$

February 1931, Hawke's Bay Earthquake (Source: Dowrick, 1998 (a))

Figure 2 Napier Hospital Nurses Home before (left) and after (right) (Source: Alexander Turnbull Library)

Figure 3 Map of Napier showing Ground Classes A, B, and C (Dowrick et al, 1995)

Figure 4 Response Spectrum of February 3 1931Earthquake, Napier, Ground Class B

Figure 5 Variables for Wall Restoring Moment, $M_{\text {restoring }}$

Figure 6 Length of return for walls

Figure 7 Cumulative Frequency Chart for Ratios of Overturning to Restoring Moment of Walls,

for the Estimated Seismic Load

Figure 8 Cumulative Frequency Chart for Ratios of Overturning to Restoring Moment of Walls,

for the Code Load

Figure 9 Cumulative Frequency Chart for Ratios of Applied Shear Force to Calculated Shear

Strength of Walls, for the Estimated Seismic Load

Figure 10 Cumulative Frequency Chart for Ratios of Applied Shear Force to Calculated Shear

Strength of Walls, for the Code Load

Figure 11 Overturning Ratios / Shear Ratios for Walls, for the Estimated Seismic Load

Figure 12 Cumulative frequency chart for Ratios of Applied Shear Force to Calculated Shear

Strength and Applied Bending Moment to Calculated Bending Strength of Moment

Resisting Frames, for the Estimated Seismic Load

Figure 13 Cumulative frequency chart for Ratios of Applied Shear Force to Calculated Shear

Strength and Applied Bending Moment to Calculated Bending Strength of Moment

Resisting Frames, for the Code Load

Figure 14 Occurrences of Different Structural Footprints for Infill Frames, Open Frames and

Walls

Figure 15 Response Spectrum of February 31931 Earthquake, Napier, Ground Class A (after

McVerry et al, 2000)

Figure 16 Response Spectrum of February 31931 Earthquake, Napier, Ground Class B (after

McVerry et al, 2000)

Figure 17 Response Spectrum of February 31931 Earthquake, Napier, Ground Class C (after

McVerry et al, 2000)

Figure 18 Response Spectrum of February 31931 Earthquake, Hastings, Ground Class C (after

McVerry et al, 2000) 


\section{Introduction}

\section{Introduction}

Towns and cities in New Zealand include a large number of pre-1940 buildings in their building stock. There are several reasons for this. During the latter half of the $19^{\text {th }}$ century many communities appeared on New Zealand's landscape and during the first thirty years of the $20^{\text {th }}$ Century many of them thrived due to economic growth. Along with that growth came a change in the types of buildings that were constructed. Though many buildings were originally built in timber, they were subsequently upgraded to brick and concrete. The weak economy of post-World War Two New Zealand forced some owners to abandon their businesses. New Zealand also prides itself in the preservation of many of its older buildings. The end result is a large stock of pre-1940 buildings of reinforced concrete and brick.

This thesis investigates the possibility that current earthquake engineering practice concerning these classes of structures may underestimate their ability to withstand high intensity earthquakes, and therefore require such buildings meet higher than necessary earthquake standards. The excellent seismic performance of such buildings during the 1931 Hawke's Bay earthquake suggests that some low-rise non-domestic reinforced concrete buildings may not require upgrading.

The earthquake that struck the Hawke's Bay region in 1931 devastated many commercial buildings. Many were constructed of unreinforced brick masonry but most of those left standing consisted of reinforced concrete structural wall, reinforced concrete frame with brick infill, reinforced concrete moment resisting frame or timber construction.

The thesis compares the structural performance of 25 buildings, which survived the earthquake without any significant recorded structural damage, with current design standards. It investigates whether the required seismic performance of these types of buildings is in fact too conservative. Perhaps these types of buildings do not require structural upgrading. The research identifies possible factors that are relevant. 


\section{The Earthquake}

The Hawke's Bay, New Zealand earthquake occurred at 10.42am (Local Time) on February $3^{\text {rd }}, 1931$ with a surface-wave magnitude of $M_{s}=7.8$. The fault rupture was predominantly thrust with a rupture surface adjacent to both Napier and Hastings, the two largest towns in Hawke's Bay, extending from about $30 \mathrm{~km}$ depth to within $5 \mathrm{~km}$ of the surface.

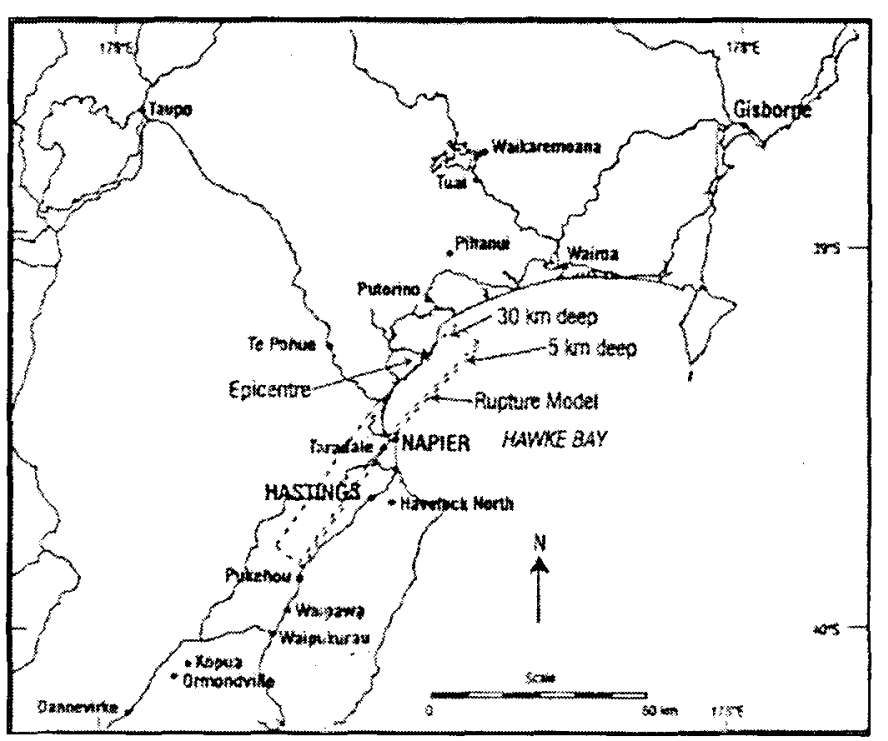

Figure 1 Map showing location of Hastings and Napier and the rupture plane for $M_{s} 7.83$ February 1931 , Hawke's Bay Earthquake (Source: Dowrick, 1998 (a))

\section{The Buildings}

Of all the reinforced concrete buildings that survived the earthquake, some 100 buildings, only a few suffered minor structural damage and only one, the Napier Hospital Nurses' Home, collapsed (see Figure 2). The construction of this building is not representative of the construction period prior to the earthquake as there were large arches at ground floor, creating a soft storey, and necessary reinforcing was omitted in many of the structural elements. The remainder suffered little or no structural damage and of the initial survivors, 25 are in existence today. 


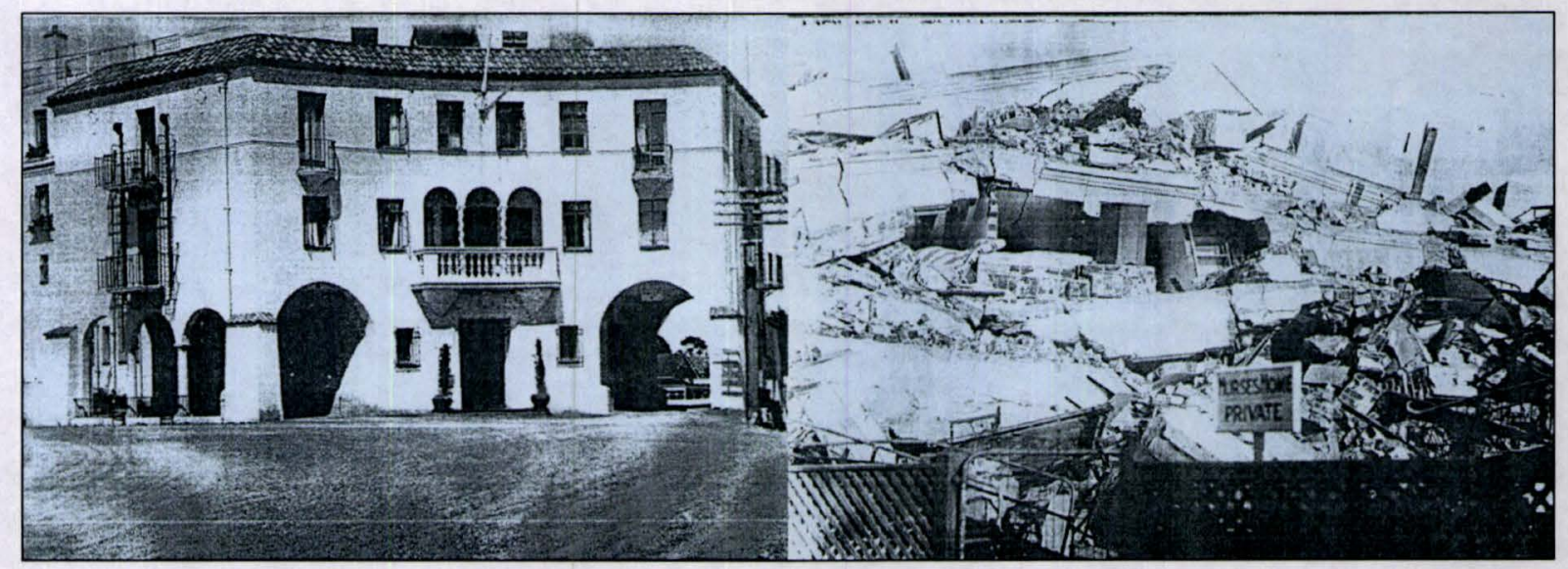

Figure 2 Napier Hospital Nurses Home before (left) and after (right) (Source: Alexander Turnbull Library)

The following is a list of the buildings and their addresses ${ }^{1}$ used in this study:

\section{Napier}

Methodist Church Hall, 3A Clive Square

Gilberd \& Co, 47 Kennedy Road

Hawke's Bay County Council Offices, 6-10 Browning Street

Public Trust Office, 42 Tennyson Street

Murdoch (J H), Bakery, 14A Dalton Street

Dalgety \& Co, 33-35 Dickens Street

Ancient Order of Foresters, 50 Dickens Street

Ringland Bros., 11 Hastings Street

Union Hotel, 7 Waghorne Street, Port Ahuriri

Harston's Concert Hall, 13-17 Hastings Street

Bennett Building, 61-63 Hastings Street

Parker Chambers, 32 Hastings Street

Williams Buildings, 100-110 Hastings Street

Williams Buildings, 236-238 Hastings Street

Richardson \& Co. Ltd., 21 Bridge Street, Port Ahuriri

Howe Bros., 7 Hastings Street

West (JS) \& Co, 84 Emerson Street 


\section{Hastings}

Poppelwells, 119-129 Russell Street North

Dominion Buildings, 116-120 Queen Street East

Public Trust Office, 201 Karamu Road North

Rainbow, Hobbs \& Nesbitt, 126 Queen Street

Hawke's Bay Jockey Club, Steward Stand, 601 Market Street North

Hawke's Bay Farmer's Co-Operative, 120-124 Market Street North

Webber's Buildings, 117 Russell Street North

Villa d'Este, 331-333 Heretaunga Street West

\section{The Structural Systems}

The buildings listed above have one or two of the following primary lateral load resisting structural systems:

1. Reinforced Concrete Structural Wall

2. Unreinforced Brick Masonry Infill Frame

3. Reinforced Concrete Moment Resisting Frame

Each building is analysed in both orthogonal directions. The transverse direction is normally parallel to the adjoining street and the longitudinal direction is perpendicular to it (though there are exceptions). Some buildings are classed as 'corner buildings' as they have two stiff facades and two relatively flexible facades, and are normally found on street corners. 


\section{Literature Review}

\section{Introduction}

This chapter examines the available literature and other resources, i.e., drawings, people; establishes the Methodology; and quantifies the main variables:

- Ground Class of soil sites - what different site soils are there?

- Building data - what data is needed for the analyses?

- Earthquake Risk Buildings - what constitutes an ERB?

- Building damage - What records of damage are there globally and for specific buildings?

- Infill wall performance - what other research of theoretical and real behaviour exists?

- Infill panel failure modes - what failure modes are there?

- Approximate Assessment Procedure - what are the precedents for assessment of these buildings?

\section{Site Soil Ground Classes}

The following is an extract from a paper on damage ratios to houses and microzoning effects for this earthquake (Dowrick et al, 1995). It describes the ground classes used in this study:

Ground Class

A

Rock

B Dense sands and fine-medium gravels of the sand spits. These materials are classed as 'firm ground'. The top 5-10 $\mathrm{m}$ at least, is likely to comprise very

Firm dense sands and gravels deposited in a high-energy beach environment. Experience with similar materials indicates that they will exhibit SPT $\mathrm{N}^{2}$ values $\geq 50$, and are unlikely to show ground damage due to high intensity shaking.

C Reclaimed swamp and lagoon areas. These are classed as 'soft ground' and are likely to vary both laterally and with depth, and to consist predominantly

Soft of poorly consolidated, saturated, fine grained soils (muds) and organic material with peat horizons to moderate depths (possibly up to $30 \mathrm{~m}$ or more). 
Figure 3 shows the three ground classes where they occur in Napier. The buildings in Hastings are all assumed to be located on Ground Class C.

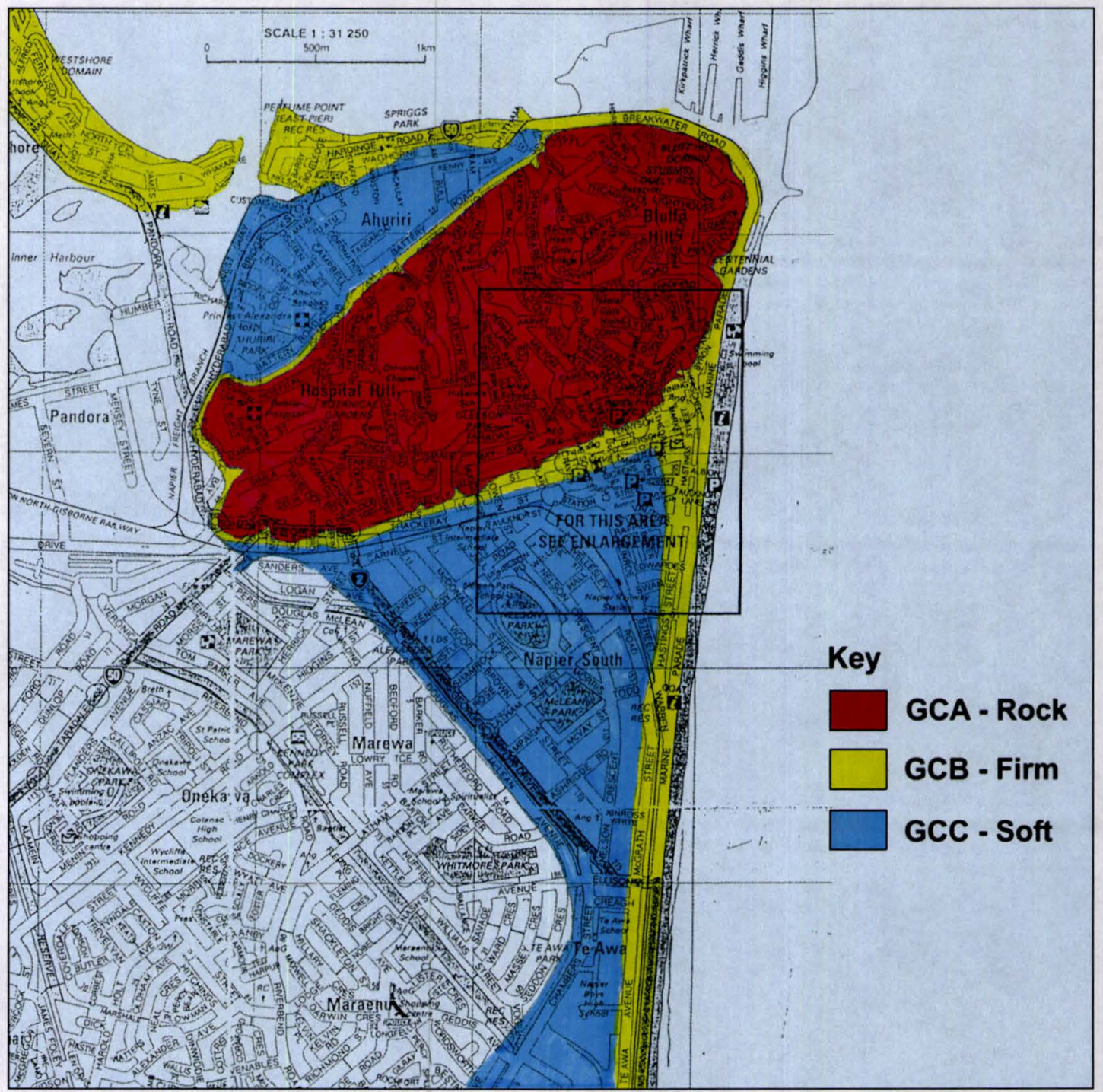

Figure 3 Map of Napier showing Ground Classes A, B, and C (Dowrick et al, 1995)

\section{Building Data}

Previous studies by Dowrick (1995-1998) and others on the damage to domestic buildings and general information, including fatalities, from the 1931 earthquake have provided the following information:

- Predicted fault rupture and peak ground accelerations from attenuation models (McVerry et al, 2000);

- Soil classifications of affected areas (including areas where the buildings under study are located);

- Maps providing information about commercial buildings (including damage due to the 
earthquake and post-quake fire);

- Photographs providing evidence of damage done to the buildings under study and their structural systems (detail and aerial photographs);

- Building drawings;

- Many human sources of information.

These sources provide information for most of the buildings under study including the structural system(s) of each building and records of damage.

\section{Earthquake Risk Buildings}

The study of reinforced concrete Earthquake Risk Buildings (ERBs) or High Risk Buildings (HRBs) has existed for at least two decades. The focus of these studies in New Zealand to date has been wide ranging. Park (1981) reviews code developments for earthquake resistant design of concrete structures. A working group from the New Zealand National Society for Earthquake Engineering reports on the assessment and improvement of the structural performance of ERBs (NZNSEE, 1996) and another group reports on a parametric study of benefit-cost ratios for ERBs (NZNSEE, 1997). Some of these reports are referred to in this thesis.

A study by Sritharan and Dowrick (1995) was conducted for selected buildings that were subjected to moderate seismic loading during the Magnitude 6.3 and 6.4, May 1990 Weber, New Zealand, earthquakes. There was one building studied that is of interest here being similar to some buildings from this study. It is a two-storey Moment Resisting Frame (MRF) with unreinforced brick masonry infill panels. The MRF with infill panels was modelled using dynamic time-history analysis and the results showed that, as expected, the building was significantly stiffer as a result of the infill panels when compared to an open MRF. The stresses and deformations of the building were reduced due to the infill panels.

This thesis responds to these previous studies by suggesting that the pre-code low-rise, nondomestic, reinforced concrete buildings in this study, are not ERBs, but in fact perform to a 
higher standard than either the current loading standard of New Zealand (NZS 4203:1992) or the Green Book ${ }^{3}$ suggest.

The Green Book (NZNSEE, 1996 p.49) states 'Analysis of existing moment resisting frames typical of early reinforced concrete building structures, and observations of damage caused in recent earthquakes, have indicated that the major problem areas are:

- Inadequate ductility and shear strength of potential plastic hinge regions of beams and columns due to insufficient transverse reinforcement.

- Inadequate anchorage of transverse reinforcement due to poor anchorage details.

- Inadequate shear strength of beam-column joints due to insufficient transverse reinforcement.

- Inadequate anchorage of longitudinal reinforcement due to poor anchorage details.

- Inadequate strength of footings and/or piles and their connections.

- Uncertain behaviour of the structure as a result of the presence of non-structural elements, typically infill walls, which can significantly alter the structural behaviour of the frame.

\section{Recorded Damage To Buildings}

The damage to buildings in this study, recorded by various sources, varies from "no damage" to "moderate" to "reinforced concrete part OK but brick part collapsed". It is apparent that the damage levels, on the whole, were low for the buildings in the data set.

Some sources describe the performance of reinforced concrete structures with high regard, e.g. "...where properly designed and constructed, [reinforced concrete] behaved admirably" (Mitchell, 1931). This article also describes several different structural systems and how each fared, e.g. “...(a) The mushroom head columns, flat slab, drop panelled construction survived the earthquake almost without a flaw; (b) Plain beam and column construction is exemplified in the Public Trust Office, Hastings, ... and Dalgety's, Napier, [both] of which and numerous others, were practically unharmed."

Another article (Brodie \& Harris, 1933) describing damage to buildings, states "Most of the damage...occurred in columns, and particularly ground floor columns", “...in only one

3 "The Assessment and Improvement of the Structural Performance of Earthquake Risk Buildings" (NZNSEE, 1996) 
instance was there any evidence of beam or girder failure" and "Where integral reinforcedconcrete walls had been used very little trouble occurred, but brick partition walls...were damaged."

An article, printed in the Daily Telegraph, Napier in July 1931, lists those buildings in Napier and Hastings damaged by earthquake and fire, earthquake alone and, for Hastings, a categorisation of level of damage. The following are excerpts from the article that highlights those buildings used in this study:

Napier

- "Buildings in Napier...destroyed by the holocaust (fire) in the wake of the 'quake: Howe's booksellers shop;...Ringland Bros., outfitters;...Harston's music warehouse;...Parker's Chambers;...Hawke's Bay County Council offices;...The new Napier Post Office; Bennett's Building;... West and Co., auctioneers,"

- "The more prominent buildings destroyed by fire at Port Ahuriri include...Richardsons, Ltd."

- "Some of the larger Napier buildings which withstood the earthquake are those of the Public Trust; Forester's Hall; Dalgety's;...Methodist Church [Hall]"

\section{Hastings}

- "Destruction by Earthquake and Fire[:] Webber's buildings and offices"

- "60 to 90 Per Cent. Destroyed[:] Villa Deste, flats and shops"

- "Slight to Semi-Destruction [:] racecourse grandstand"

Many of the damage records presented here are too generalised to determine precisely what damage occurred to each building. The Alexander Turnbull Library holds a large collection of photos of scenes in Napier and Hastings during and after the earthquake occurred. Many of these photos are presented in one album complete with captions and much of the recorded damage used in this study was obtained from those photos, either by the author or by Dowrick (1995-1998).

\section{Infill Frame Wall Performance}

Many studies have investigated the seismic performance of masonry infill frames and walls. For example, Murty and Jain (2000) describe favourable results of unreinforced masonry 
infill walls. They report on experimental tests of reinforced (with reinforcing bars laid horizontally in every third course of bricks) and unreinforced infill frames, and open frames of similar dimensions to those analysed in this study. Their results are summarised below:

- The average initial stiffness of an infilled frame is about 4.3 times that of a bare frame when the masonry infill is unreinforced.

- On average, unreinforced masonry infill frames have about $70 \%$ higher strength than bare frames.

- The deformability of infill frames under cyclic loading is comparable to bare frames, where infill frames sustained three cycles of $40 \mathrm{~mm}$ displacement. The yield displacement of infill frames is much smaller than that of bare frames, and hence, infill frames have considerably larger ductility, with the average being about 4 times higher than that of bare frames.

- The average energy dissipation of unreinforced infill frames is about $22 \%$ higher than that of reinforced infill frames. A comparison with the bare frame was not possible since the bare frame failed in the first $25 \mathrm{~mm}$ cycle.

- The average drop in stiffness is about $22 \%$ in the first repeat cycle and about an additional $6 \%$ in the second repeat cycle.

\section{Infill Panel Failure Modes}

Possible failure modes of infill frames are reported on by Lafeunte et al (2000):

- Non-linear behaviour of the tested walls was typically initiated by diagonal cracking of the infill combined with horizontal failure of the bed mortar joints. Infill wall failure was dominated by the shear capacity of the adjacent reinforced concrete columns. Both at the top and bottom of columns, shear cracking was noticed, followed by spalling of the cover concrete at the bottom of the columns and by severe degradation of the concrete sections, leading to a final dowel action resistant mechanism developed by the longitudinal reinforcement.

- Separations between the infill and columns were noticed but no separation was observed between the infill and top beam.

- Sliding shear failures of mortar bed joints as well as diagonal stepped cracking in the infill panel occurred, producing large local forces on frame members. Mostly in all cases, as a result of the early shear failure of the columns, the dowel mechanism described above was observed. This effect, with the friction action of mortar bed joint failure, produced a ductile response with substantial energy dissipation. The lateral strength of 
axially loaded infill walls increased between $60-80 \%$ compared to walls with no vertical load.

From these test results the following failure modes for infill frames need to be analysed:

- Diagonal tension failure;

- Compression strut failure;

- Sliding shear failure of the infill;

- Sliding shear failure of the column tops adjacent to the infill panel.

\section{Approximate Assessment Procedure}

There are several references that show the percentage of vertical structure area in plan to the gross ground floor area is a suitable yardstick to measure structural integrity. Atimtany and Tuna (1998) recommend the "area of infill shear walls [for repairing damaged masonry structures] should be at least $1 \%$ of the total gross floor area." The buildings referred to in the article are of a similar scale to those used in this study.

\section{FEMA ${ }^{4}-155$ Rapid Visual Screening of Buildings for Potential Seismic Hazards: Supporting} Documentation (ATC-21-1) - This is the base document for the Rapid Evaluation Method described in Section 4.2 of the Green Book. It reviews many Rapid Screening Procedures (RSPs) and determines an ideal RSP. Some aspects of the ideal RSP that are relevant to this study are:

- “...all building groups should at least receive an initial limited-sample test screening." As there are several structural types within the group of buildings of this study, a limitedsample is not appropriate. Therefore, every building is analysed;

- "Quantitative assessment eliminates personal bias upon evaluation. A nonabitrary ranking system should be used based on physical parameters."

Given the age of some of the buildings in the building set, it is vital that as much quantitative data and physical parameters are used to eliminate both bias and increase accuracy of results;

- "...the earthquake loading should be defined explicitly, preferably in physically based units such as acceleration." 
Again, the age of the buildings and the earthquake, necessitate the need for a quantifiable earthquake load to maximise accuracy and usefulness of the results;

- "Sufficient building-specific data should be recorded..."

As much data from on-site visits should be gleaned as access to the buildings is limited;

- "Age should be recorded. If this is not possible an estimate within a decade or two, from the architectural or constructional style, should be given."

Many of the original drawings and documentation for buildings in this study were lost either through the fires that spread over both Hastings and Napier or through council oversight. The approximate age can provide clues as to the likely construction details. Construction details can also be used from other buildings of a similar construction period;

- "Site aspects such as potential pounding between buildings, adjacent potentially hazardous building[s], and corner buildings...need to be quantified."

As the analysis of the buildings in this study is limited by time, various simplifying assumptions are made, including the effects of neighbouring structures.

The Approximate Assessment Procedure is described in Phase 5 of the Methodology in this thesis. 


\section{Methodology}

\section{Introduction}

This chapter outlines the methodology and the building selection criteria used in this study. The methodology reflects findings from the Literature Review including the approach of the Green Book methodology.

\section{Building Selection Criteria}

These criteria are used to select the buildings in this study. The building survived the 1931 Hawke's Bay earthquake is still in existence today.

- The building is 'low-rise' but not single storeyed, i.e. 2-4 storeys;

- The building has significant vertical (and horizontal) structure made of reinforced concrete;

- The building is classed as either 'commercial' or 'industrial'. 'Residential' buildings, i.e. housing, is omitted.

\section{Fieldwork}

The fieldwork carried out by the author to establish data for the buildings in this study is as follows:

- Three visits to Hastings and Napier with an initial list of probable buildings. During all visits each building was examined to determine if there was any vertical reinforced concrete structure and what was the structural system. Where no drawings of the building were available, measurements of the building and its structural system were made. Photographs of facades were also taken.

- Hastings District Council, Napier City Council, Art Deco Trust, Natusch Architects and the Hawke's Bay Museum were approached to examine their records of construction drawings, photographs and related information.

- Several informal interviews were held with older members of both communities and relatives of building owners for further information. 


\section{Research Method}

The research reported in this thesis is divided into 5 phases:

Phase 1: Determine the peak structural response of the buildings for the $M_{s} 7.8,1931$ Hawke's Bay earthquake.

Phase 2: Determine the actual loads exerted on the buildings in both orthogonal directions and calculate the forces (seismic plus gravity) in each principal structural member using equivalent static elastic analysis.

Phase 3: Calculate the probable strength of the principal structural members in the buildings using the Green Book.

Phase 4: Compare the probable strengths found in Phase 3 with the forces determined in Phase 2.

Phase 5: Develop a simplified method of estimating the seismic capacities of similar buildings.

\section{Pilot Analysis}

Two buildings were initially analysed to identify any unknown 'obstacles' that might require further data input, further research, or even further analysis. In essence, this was a pilot for the main research.

The pilot analysis checked the research methodology, and refinements were made to the procedure before the full analysis of the remaining buildings was carried out. It also identified all the necessary physical measurements of the buildings required in order to analyse them accurately. The results from the pilot study are presented in Chapter 4.

\section{Phase 1 Peak Structural Response}

The peak structural response is determined using a theoretical attenuation model (McVerry et al, 2000) that gives the median Peak Ground Acceleration (PGA) for the three different soil classifications ${ }^{5}$ and for both cities (refer Table 3-1) given their site to fault rupture plane distances. Another model by Abercrombie (McVerry et al, 2000) indicates that these predictions are well within the range of values given by other data and modern attenuation relationships. 
Table 3-1 Peak Ground Accelerations for Ground Classes A, B, and C, 1931 Hawke's Bay earthquake (after McVerry et al, 2000)

\begin{tabular}{|c|c|c|}
\hline Napier, Ground Class & Distance $\mathbf{( k m})$ & PGA $\mathbf{( g )}$ \\
\hline A & 3.5 & 0.60 \\
\hline B & 3.5 & 0.82 \\
\hline C & 3.5 & 0.48 \\
\hline Hastings, Ground Class & Distance (km) & PGA (g) \\
\hline C & 6.0 & 0.45 \\
\hline
\end{tabular}

Peak structural responses are determined from the PGAs (Refer Figure 4). The value of the seismic coefficient used to calculate the actual earthquake load on each building is determined as follows:

Seismic coefficient for a specified soil class for the 1931 Hawke's Bay earthquake $=$ (Seismic Coefficient of NZS4203: 1992, $T_{1}=0$ and $\left.\mu=1\right) \times(P G A$ of 1931 HB Earthquake) (PGA of NZS4203: 1992 at $T_{1}=0$ and $\mu=1$ )

For example, Figure 4 shows the response spectra for site subsoil category (b) from NZS4203: 1992 (firm soil). The value of the acceleration for the plateau between $T_{1}=0$ and $T_{1}=0.45$ seconds is calculated using the above equation: $(0.8 \times 0.82) / 0.42=1.56$

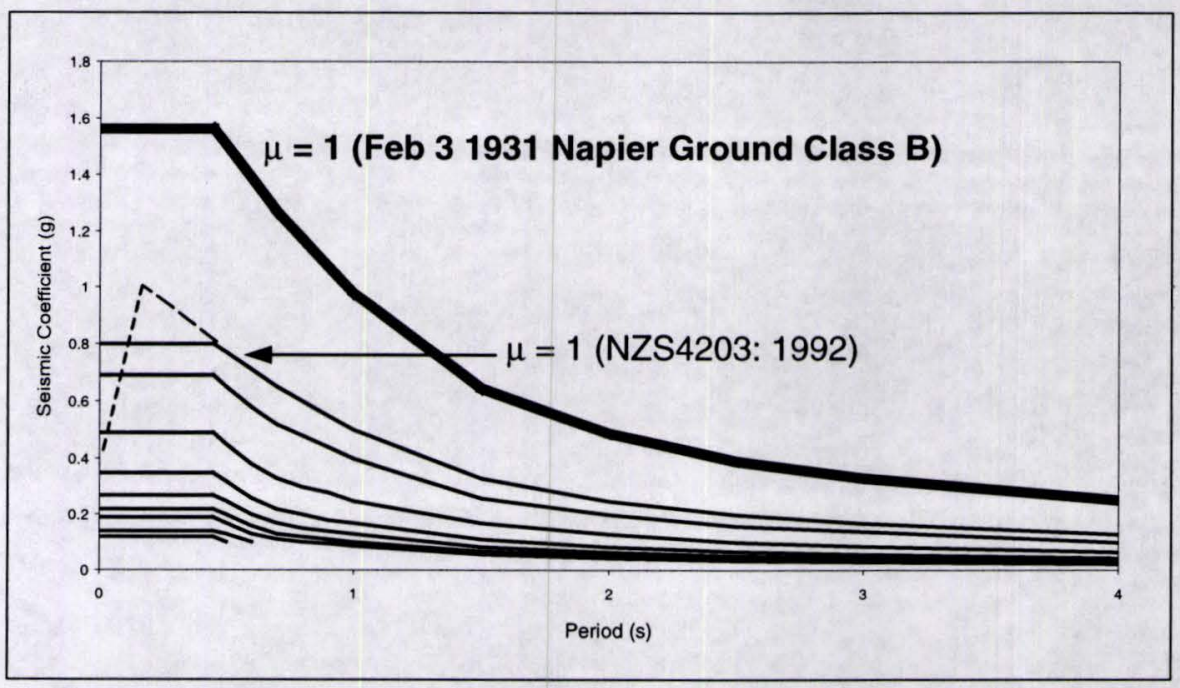

Figure 4 Response Spectrum of February 3 1931Earthquake, Napier, Ground Class B $^{6}$

6 Response spectra for all Ground Classes are found in Appendix A 


\section{Phase 2 Calculations of Forces on Members}

\section{Procedure:}

- The loads exerted on each building in both orthogonal directions are determined as per NZS4203: 1992 except that C, the lateral force coefficient, is not used but replaced by the seismic coefficient whose derivation is explained above.

- Determine the seismic coefficient, $\mathrm{C}_{\mathrm{h}}$, for each building. Assume the natural period of vibration is less than 0.45 seconds (determined after performing detailed analyses on two buildings) and assuming $\mu=1$ in the first instance ${ }^{\text {. }}$

- Determine the seismic weight, $\mathrm{W}_{\mathrm{t}}$, of the building.

- Distinguish structure from non-structure, a 'structural skeleton' drawing identifies primary and secondary structural elements.

- Table 3-2 lists all the materials and their densities used in all buildings.

Table 3-2 Densities and weights of materials and typical construction types.

\begin{tabular}{|l|c|}
\hline Material & $\mathbf{k N ~ m}^{-3}$ \\
\hline Timber - Radiata Pine & 5.4 \\
\hline Iron & 76.0 \\
\hline Mild Steel & 79.0 \\
\hline Brickwork - commons & 19.6 \\
\hline Reinforced Concrete & 23.5 \\
\hline Construction & $\mathbf{k N ~ m}^{-2}$ \\
\hline Windows & 0.22 \\
\hline Timber Stud Partition Wall & 0.20 \\
\hline Corrugated Steel (18, 20 gauge) & $0.12,0.17$ \\
\hline
\end{tabular}

- Calculate the horizontal seismic shear force, $\mathrm{V}=\mathrm{C}_{\mathrm{h}} \mathrm{W}_{\mathrm{t}}$

- Determine the lateral force at each floor level, $\mathrm{F}_{\mathrm{i}}=0.92 \mathrm{~V}\left(\mathrm{~W}_{\mathrm{i}} \mathrm{H}_{\mathrm{i}}\right) /\left(\Sigma \mathrm{W}_{\mathrm{i}} \mathrm{H}_{\mathrm{i}}\right)$

Where $\mathrm{W}_{\mathrm{i}}$ and $\mathrm{H}_{\mathrm{i}}$ are the seismic weights and height from ground of floor level $i$ respectively.

- Perform an elastic analysis using Microstran ${ }^{\odot}$, a structural engineering computer package. The following steps are taken to perform each analysis:

$7 \mu=1$ on the basis that little structural damage was reported for most buildings and so are all assumed to respond elastically. 
- Create the geometry of the structure using the 'structural skeleton' drawing for each building (drawn from available sets of drawings and other sources).

- Define material properties such as density, cross sectional dimensions, Young's modulus. Input the (rigid or pinned) supports at the base of the structure.

- Gravity and seismic loads are applied separately to each member as appropriate.

- Perform an elastic analysis for the load combination, Gravity + Seismic.

\section{Phase 3 Calculations of Probable Member Strength}

This phase uses relevant sections from the Green Book. Assumptions made in the analysis that are common to all buildings are as follows:

- Reinforcing steel, assumed to be plain round bars, has a tensile yield stress of $280 \mathrm{MPa}$, at a yield strain of 0.0014 (Dowrick, D.J. \& Brunsdon, D., 1999, pers. comm.);

- Masonry infill mortar is assumed to have a compression strength, $\mathrm{f}_{\mathrm{m}}^{\prime}$, of $12 \mathrm{MPa}$, a modulus of elasticity of $18000 \mathrm{MPa}$, and a direct tensile strength, $\mathrm{f}_{\mathrm{tm}}$, of $0.4 \mathrm{MPa}$ (Sahlin, 1971);

- Concrete is assumed to have a compression strength, $\mathrm{f}^{\prime}$, of $21 \mathrm{MPa}$ (based upon a $25 \%$ increase from 28-day strength of 16.6MPa (Barnard, D., 1999, pers. comm.)) and a modulus of elasticity of $21000 \mathrm{MPa}$;

- For all wall analyses, an ultimate soil pressure on foundations of $300 \mathrm{kPa}$ is assumed (Charleson, A.W., 1999, pers. comm.);

- Masonry panels are assumed to have no steel reinforcing.

\section{Moment Resisting Frames}

Step 1: Determine whether the frames contain infill panels; if the answer is yes then proceed to Step 2; if the answer is no then proceed to Step 4. Equations 3-8(c) are from the Green Book. Equations 9-11(c) are from Charleson (1999, pers. comm.).

Step 2: Decide on the failure mode of the infill panels from the following three potential modes:

a. Sliding shear failure along horizontal mortar courses

$$
\mathrm{V}_{\mathrm{s}}=\varphi\left[\left(0.03 \mathrm{n} \mathrm{f}_{\mathrm{m}}^{\prime}\right) /(1-0.3 \mathrm{~h} / l)\right] l \mathrm{t}
$$


where $\mathrm{f}^{\prime}{ }_{\mathrm{m}}$ is the compression strength of the infill panels of thickness $\mathrm{t}$, height $\mathrm{h}$, and $\mathbf{n}$ is the number of bays of approximately equal length $l$ in the frame. $\mathrm{n}$ is assumed to be unity, and the wall strength is calculated as the sum of individual panel strengths. $\varphi$ is the strength reduction factor, assumed to be 0.7 for unreinforced masonry. ${ }^{8}$

b. Compression failure of a diagonal strut

$$
\mathrm{V}_{\mathrm{c}}=\varphi \mathrm{R}_{\mathrm{c}} \cos \theta
$$

where the diagonal compression failure force,

$$
\mathrm{R}_{\mathrm{c}}=2 / 3 \mathrm{Ztf^{ \prime }}{ }_{\mathrm{m}} \sec \theta
$$

where the contact length between panel and column,

$$
z=\pi / 2\left[\left(4 E_{c} I_{g} h\right) /\left(E_{m} t \sin 2 \theta\right)\right]^{0.25}
$$

where $E_{c}$ and $E_{m}$ are the moduli of elasticity of frame and infill; $I_{g}$ is the concrete column moment of inertia; and $\theta$ is the angle between the diagonal strut and the horizontal.

c. Diagonal tension cracking

$$
V_{D}=\varphi \pi / 2 t d_{m} f_{t m} \cos \theta
$$

where $d_{m}$ is the diagonal length of the panel, and $f_{t m}$ is the direct tensile strength of the masonry infill (given from a ratio of tensile to compressive strength of 1:30 (Sahlin,1971)).

Step 3: Check the sliding shear capacity of the top of the column adjacent to the infill panel:

$$
V=\varphi \mu_{\mathrm{f}}\left(\left(\mathrm{A}_{\mathrm{v}} \mathrm{f}_{\mathrm{y}}\right)+\mathrm{N}^{*}{ }_{\text {nett }}\right)
$$

where the friction coefficient of the column, $\mu_{\mathrm{f}}=1.4 \lambda(\lambda=1.0)$

8 This value has been derived by using NZS4230: 1990, Code of practice for the design of masonry structures, as a guide. 
$\mathrm{N}^{*}{ }_{\text {nett }}=\mathrm{N}^{*}-\mathrm{T}$, where $\mathrm{T}$ is the vertical component of the compression strut (any tension caused by the overturning moment), and $\varphi$, the strength reduction factor, is 0.85 for concrete.

Step 4: Calculate the probable shear strength of the beams

$$
V_{p}=\varphi\left(k \sqrt{f^{\prime}}{ }_{c} b_{w} d+A_{v} f_{y t} d / s\right)
$$

where $\mathrm{k}=0.2, \mathrm{f}_{\mathrm{yt}}$ is the probable yield strength of the shear reinforcement, $\mathrm{A}_{\mathrm{v}}$ is the area of transverse shear reinforcement at spacing $s, d=$ effective depth of the beam, $b_{w}$ is the width of beam web, and $\mathrm{f}^{\prime}{ }_{\mathrm{c}}$ is the probable concrete compressive strength (assumed to be $21 \mathrm{MPa}$ (3000psi) which is an increase of $25 \%$ from the 28 -day strength of $16.6 \mathrm{MPa}(2400 \mathrm{psi})$ ).

Calculate the probable shear strength of columns

$$
\mathrm{V}_{\mathrm{p}}=\varphi\left(0.85\left(\mathrm{~V}_{\mathrm{c}}+\mathrm{V}_{\mathrm{s}}+\mathrm{V}_{\mathrm{n}}\right)\right)
$$

Where shear resisted by the concrete mechanisms,

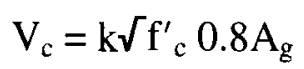

where $\mathrm{k}=0.29$ and $\mathrm{A}_{\mathrm{g}}=$ gross area of the column; and

Shear resisted by the shear reinforcement assuming a critical diagonal tension crack of $30^{\circ}$ to the longitudinal axis of the column,

$$
V_{s}=\left(A_{v} f_{y t} d^{\prime \prime} / s\right) \cot 30^{\circ} \text { (for rectangular hoops) }
$$

where $A_{v}$ is the total area of hoops and cross ties in the direction of the shear force at spacing, $\mathrm{s}$ and $\mathrm{d}^{\prime \prime}$ is the depth of the concrete core of the column measured in the direction of the shear force for rectangular hoops; 
And shear resisted as a result of the axial compressive load $\mathrm{N}^{*}$ on the column,

$$
\mathrm{V}_{\mathrm{n}}=\mathrm{N}^{*} \tan \alpha
$$

where for a cantilever column $\alpha$ is the angle between the longitudinal axis of the column and the straight line between the centroid of the column at the top and the centroid of the concrete compression force of the column section at the base, and for a column in double curvature $\alpha$ is the angle between the longitudinal axis of the column and the straight line between centroids of the concrete compressive forces of the column section at the top and the bottom of the column.

Step 5: Calculate the probable bending strength of beams and columns:

$$
\mathrm{M}_{\text {probable }}=\varphi \mathrm{A}_{\mathrm{s}} \mathrm{f}_{\mathrm{y}}(\mathrm{d}-\mathrm{a} / 2) \text { where }
$$

$$
a=\left(A_{s} f_{y}\right) /\left(0.85 f_{c} b\right)
$$

\section{Structural Walls}

Step 1: Calculate the wall restoring-moment (refer Figure 5),

$$
\mathrm{M}_{\text {restoring }}=\mathrm{W}_{\mathrm{w}} \mathrm{x} \mathrm{d}
$$

Determine $\mathrm{W}_{\mathrm{w}}=$ seismic weight of wall + weight of foundations

Determine length of foundation on which soil pressure acts,

$\mathrm{a}=\mathrm{W}_{\mathrm{w}} /\left(\mathrm{P}_{\text {soil }} \times \mathrm{b}\right)$

where $b$ is the width of the foundation and $P_{\text {soil }}$ is the soil pressure (assume $300 \mathrm{kPa}$ )

Determine $\mathrm{d}$, the lever arm for the compression load $\mathrm{W}_{\mathrm{w}}$,

$d=L_{w} / 2-a / 2$

Determine the wall shear capacity, $V_{i}=V_{c p}+V_{s}$

where

$$
\begin{aligned}
& V_{c p}=\left(5-\mu_{s d}\right)\left(V f^{\prime}{ }_{c}+N^{*} / A_{g}\right) / 16 b d_{e f f} \\
& \mathrm{~V}_{\mathrm{s}}=\mathrm{A}_{\mathrm{v}} \mathrm{f}_{\mathrm{y}}(\mathrm{d} / \mathrm{s})
\end{aligned}
$$

for moderate ductility demands $\left(\mu_{\mathrm{sd}}<3\right)$. In this study, $\mu=1$ is assumed. 


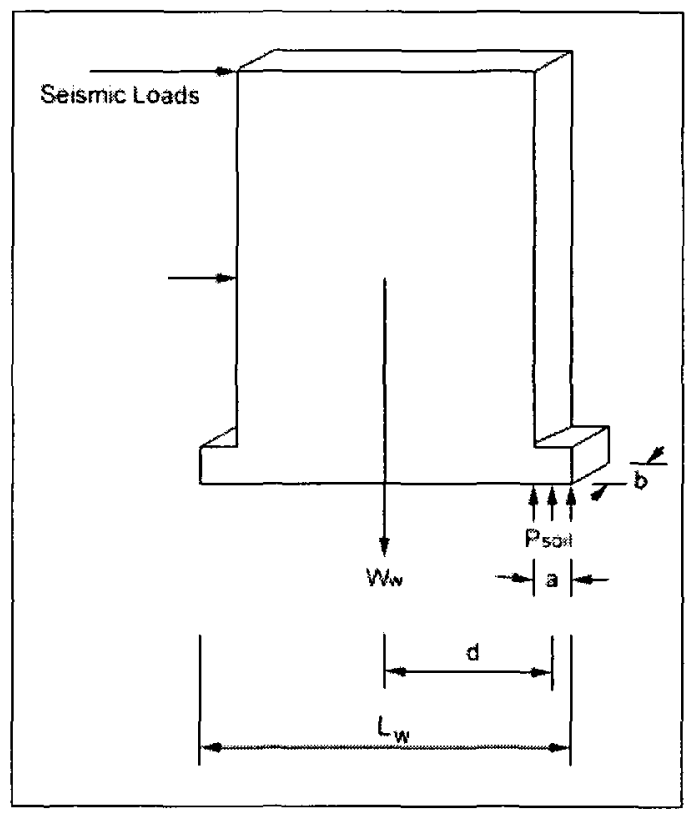

Figure 5 Variables for Wall Restoring Moment, $M_{\text {restoring }}$

\section{Phase 4 Comparisons of Results}

The final step is to compare the actual maximum shear forces and bending moments experienced in the building, obtained via the computer model (Phase 2), with the calculated probable shear and bending strengths (Phase 3) and express them as ratios.

This phase also collates all the ratios for the ground floor members and walls into a single table for all the buildings under study (see Appendix B). Included in this table are the number of storeys, the gross floor areas and the Results Reliability Ratings (RRR), as determined by the grading system described below. The RRR grade allows for the uncertainties that have emerged (see Global Uncertainties) throughout the modelling and analysis of each structure.

The ratios and percentages from the buildings under study that have a RRR of $A$ or $B$ are graphed. Those with a RRR of $\mathrm{C}$ are not considered as the uncertainties contained within the ratios are large and hence the ratios are not reliable. (An exception is the overturning moment to restoring moment ratios, as these ratios are largely independent of RRR rating.) Each structural type is examined separately, further broken down into the orthogonal directions, transverse and longitudinal. 


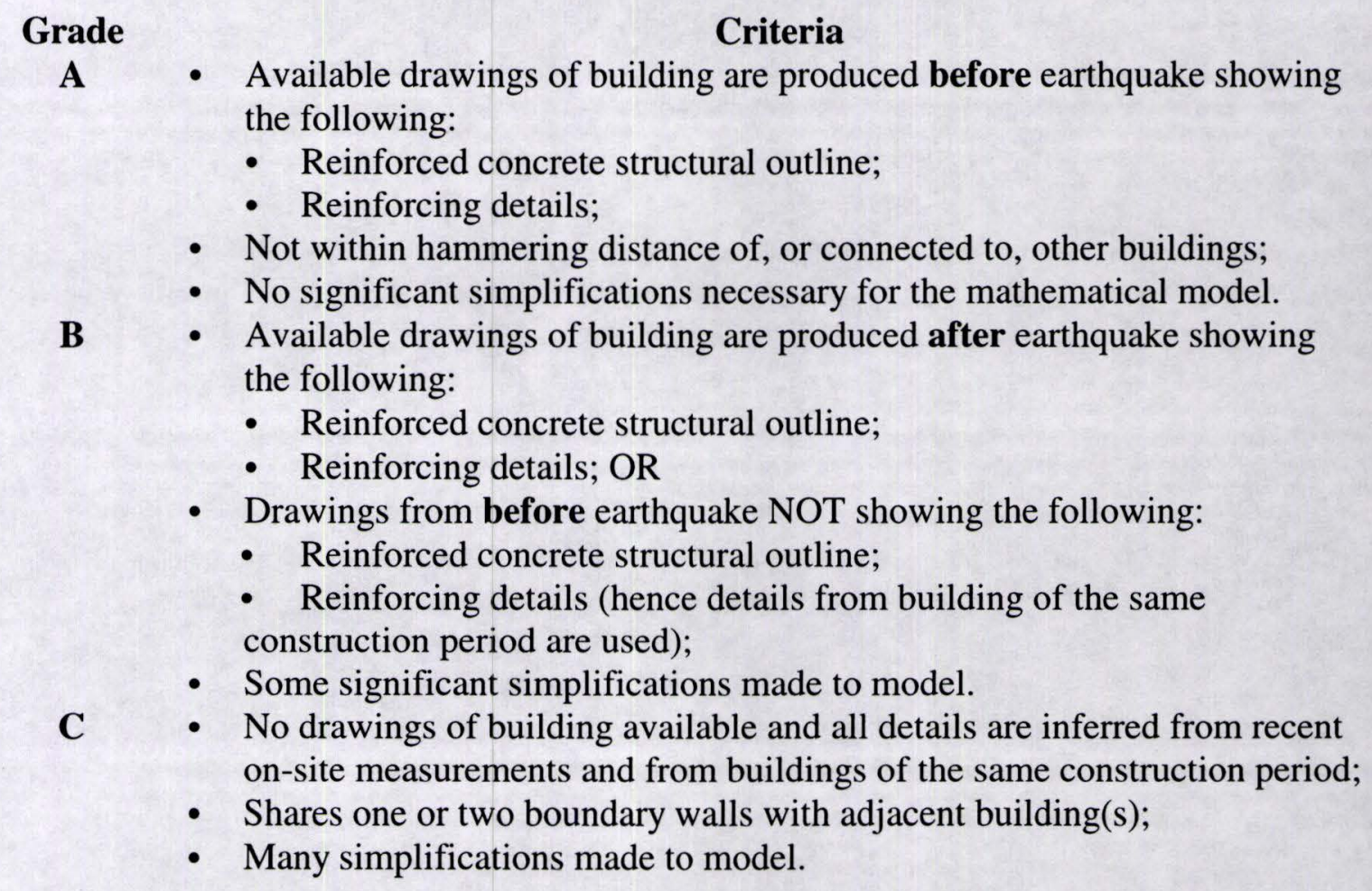

\section{Global Assumptions}

The following assumptions are made in modelling the buildings of this study:

- All beam-column joints have rigid offsets. This models the beam-column joint rigidity and gives results at the ends of members rather than at the centrelines.

- All column-base supports are rigid.

- All infill panels included are modelled as pin-jointed diagonal compression struts.

- The foundations of structural walls, as appropriate, are I or U-shaped to take into account the returns of foundations at their ends. The length of wall return used to determine the restoring moment of the wall is found as follows (see Figure 6):

- For reinforced concrete walls, the length of the return wall is equal to the footing width directly under the wall plus a length of footing under the return wall is equal to half the wall height.

- For unreinforced brick masonry infill walls, the length of the return wall is equal to the footing width directly under the wall plus a length of footing under the return wall equal to one quarter the height of the wall. 


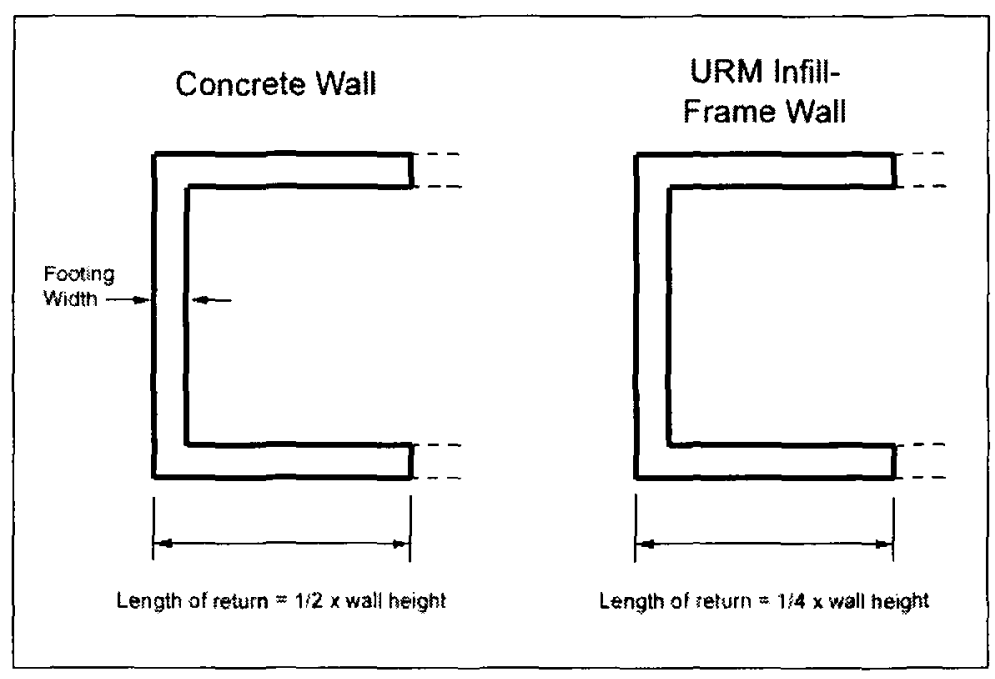

Figure 6 Length of return for walls

- Where a moment resisting frame beam is integrated with a reinforced concrete floor or roof, the flange width is less than or equal to one quarter the span length of the beam; the effective overhanging slab width is less than or equal to eight times the slab thickness or half the clear distance to the next parallel beam.

- Where reinforcing details are not available for a given building, the reinforcing used in the Gilberd \& Co. building is assumed (see Chapter 4). This building was built in 1929, a date close to the construction dates of most buildings. The reinforcing details given are for columns, beams and walls, providing both bar diameter and spacing. These details correlate closely with reinforcing in other buildings in this study. Details from other centres, such as Wellington and Wairoa ${ }^{9}$, confirm these details follow the trends of the construction period of the buildings in this study.

- A stiff reinforced concrete floor or roof diaphragm is modelled by using very stiff, pinjointed, steel beams with a cross-sectional area of $1 \mathrm{~m}^{2}$. The beams are pin-jointed so that only axial loads are transferred.

9 Wellington City Council Archives and Dowrick (pers. comm.), 1999, respectively. 


\section{Phase 5 Approximate Assessment Procedure}

This phase intends to develop a method of seismic performance evaluation that is similar to the Rapid Evaluation Procedure (REP) explained in the Green Book. The REP uses the gross floor area of a building to limit risk exposure.

The proposed method is based upon the area of vertical reinforced concrete structure at ground floor, expressed as a percentage of the gross ground floor area. The percentages are used to determine the minimum structural footprint required to avoid structural damage during a similar earthquake in a similar situation. 


\section{Pilot Analysis Results}

\section{Introduction}

This chapter presents the results from the Pilot Analysis. Building descriptions are given, along with structural skeleton drawings, and conclusions are drawn from the results. Only results for principal members are discussed.

\section{Building Descriptions}

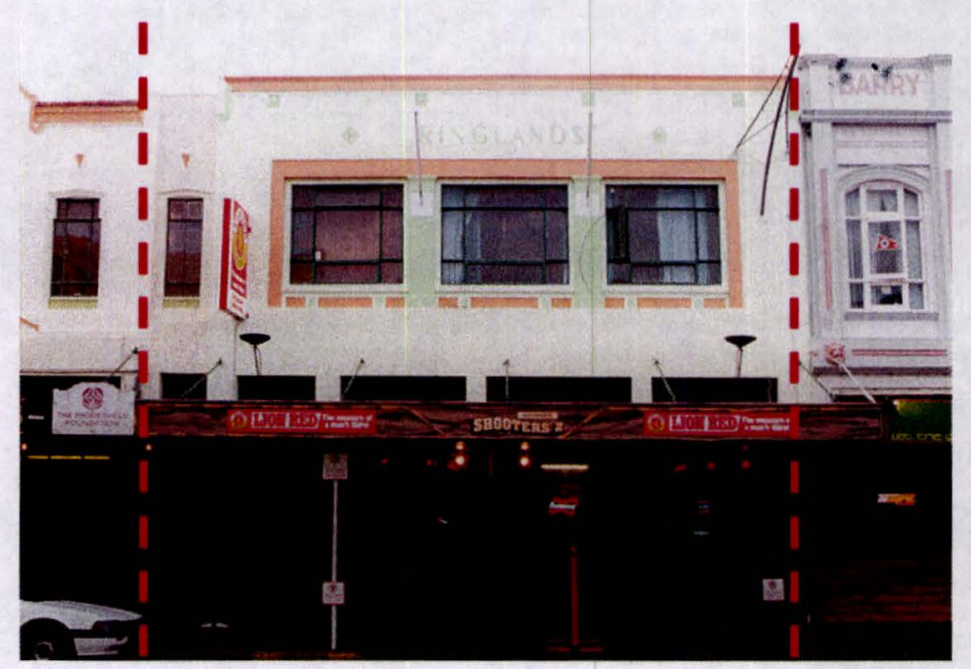

Building Name: Ringland Bros

Address: 11 Hastings St, Napier

Date of construction: $\mathrm{c} 1930$

Primary lateral load resisting structural systems:

Transverse - One reinforced concrete frame with unreinforced brick masonry infill panels.

Longitudinal - One reinforced concrete wall and one reinforced concrete frame with unreinforced brick masonry infill panels.

Construction: The roof is reinforced concrete for the two-storey portion and timber framed with corrugated steel for single storey portion. Intermediate floor is also reinforced concrete.

Recorded notes on damage: Walls intact after fire; brick badly cracked (Dowrick, 1998).

Assumptions made in modelling:

- Influence of adjacent buildings is not considered even though some structural members are shared;

- Half of the single storey (rear) portion of structure is not modelled and not included in 
seismic weight calculations as the diaphragm attached to it at level 1 is a timber framed roof (too flexible).

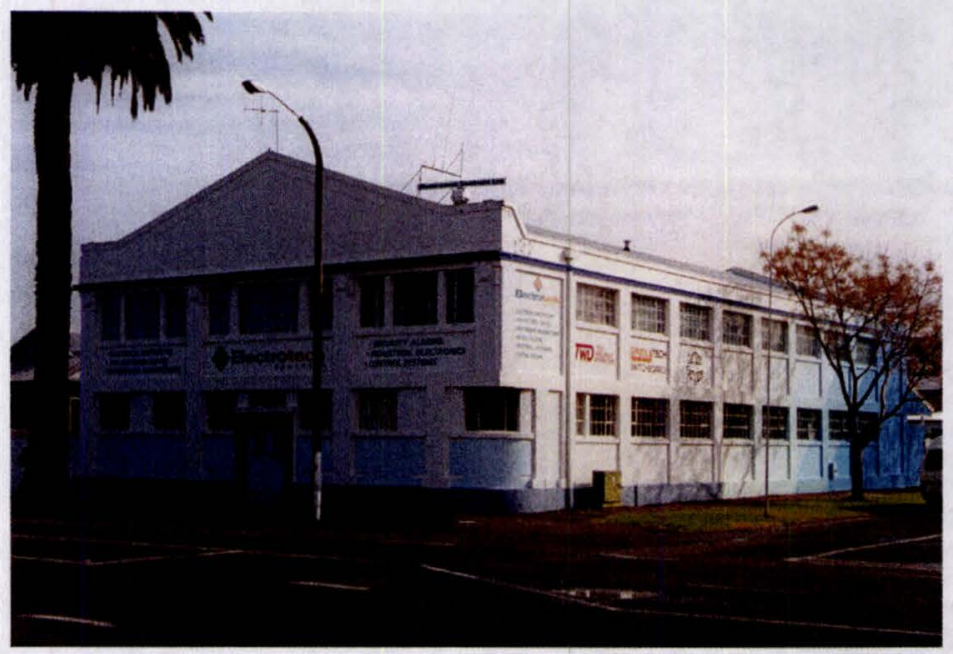

Building Name: Gilberd \& Co

Address: 47 Kennedy Rd, Napier

Date of construction: 1927

\section{Primary lateral load resisting structural systems:}

Transverse - Two reinforced concrete frames with reinforced concrete spandrels and two internal single storey reinforced concrete walls.

Longitudinal - Two reinforced concrete frames with reinforced concrete spandrels. Construction: The intermediate floor is of timber supported by steel joists and steel columns. The roof is of lightweight construction (timber and corrugated steel sheeting).

Recorded notes on damage: No visible damage (Dowrick notes, 1998).

Assumptions made in modelling:

- All spandrels are of reinforced concrete and influence frame actions. Spandrels are modelled as beams;

- The transverse facade has a gable end of $125 \mathrm{~mm}$ reinforced concrete, $125 \mathrm{~mm}$ thickness. The gable is modelled as beams of increasing depth. All beams and columns have appropriate rigid offsets from the joints;

- The longitudinal facade is modelled as a frame where end bays behave as walls;

- The internal reinforced concrete walls at ground floor level are modelled and are connected in the model to the remaining structure via very stiff pin-jointed members tied at level 1. 


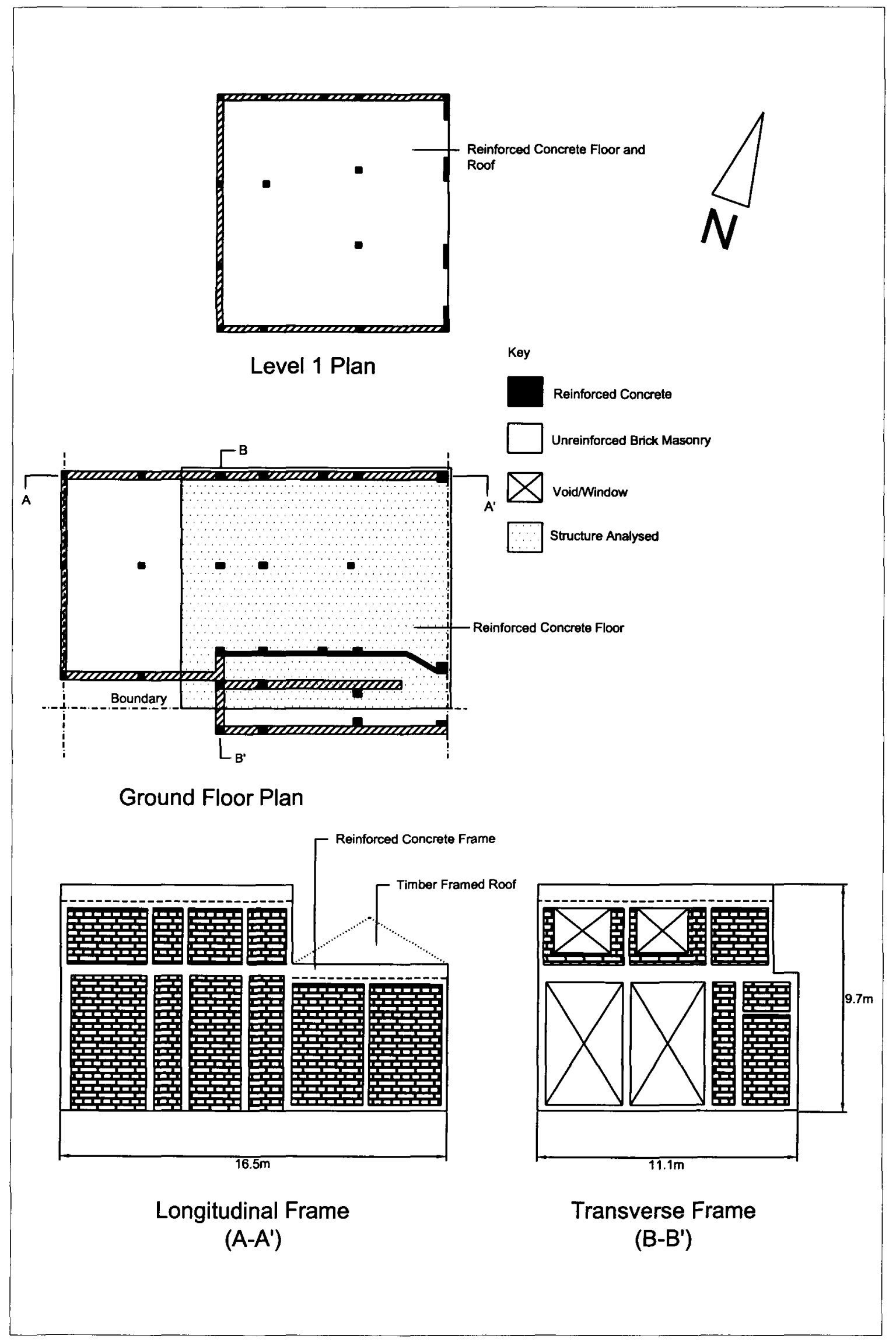

Ringland Bros. 


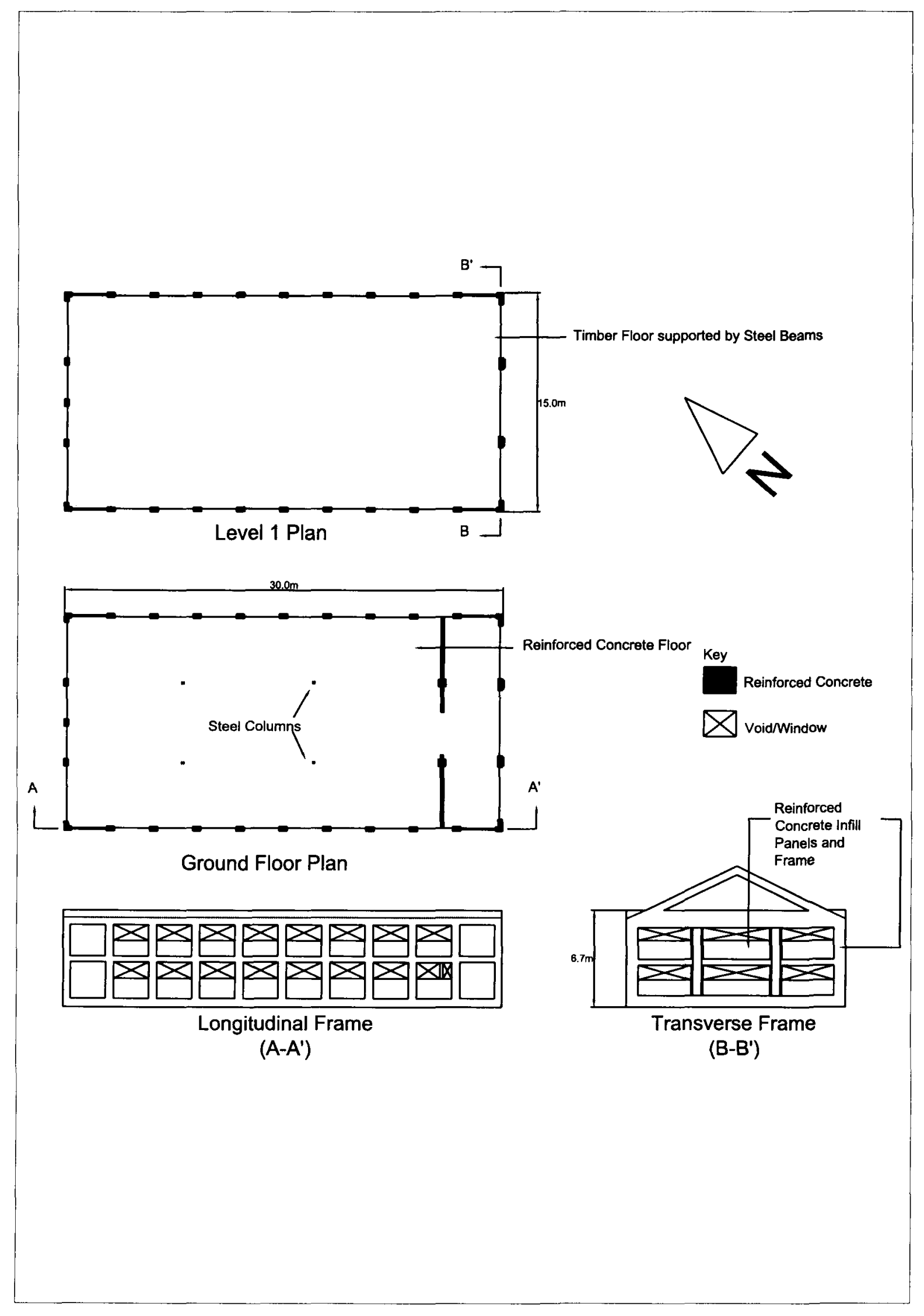

Gilberd \& Co. 


\section{Results}

\section{$\underline{\text { Ringland Bros }}$}

\section{$\underline{\text { Seismic Loads }}$}

The variables for the seismic load calculation are summarised in the table below.

Table 4-1-1 Summary of Seismic Load Variables for Ringland Bros building (Transverse and Longitudinal)

\begin{tabular}{|l|l|l|l|}
\hline $\boldsymbol{\mu}$ & $\mathbf{C}$ & $\mathbf{W}_{\mathbf{t}}(\mathbf{k N})$ & $\mathbf{V}(\mathbf{k N})$ \\
\hline 1 & 1.56 & 1885 & 2941 \\
\hline
\end{tabular}

\section{$\underline{\text { Results }}$}

Table 4-1-2 Summary of results of transverse frame for Ringland Bros building

\begin{tabular}{|c|c|c|c|c|c|c|c|c|c|c|c|}
\hline \multirow[b]{2}{*}{$\begin{array}{l}\text { Member } \\
\text { Type }\end{array}$} & \multirow[b]{2}{*}{ 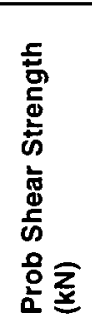 } & \multirow[b]{2}{*}{ 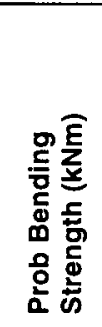 } & \multirow[b]{2}{*}{ 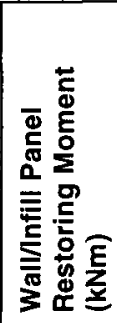 } & \multicolumn{4}{|c|}{ Strength of Infill Panels } & \multirow[b]{2}{*}{ 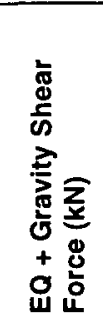 } & \multirow[b]{2}{*}{ 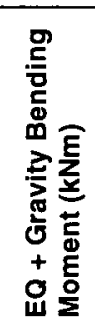 } & \multirow[b]{2}{*}{ 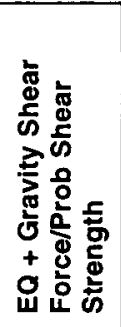 } & \multirow[b]{2}{*}{ 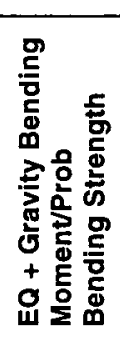 } \\
\hline & & & & 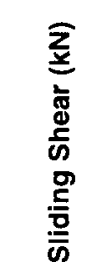 & 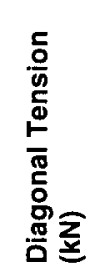 & 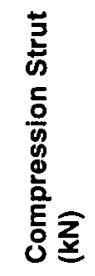 & 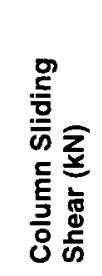 & & & & \\
\hline $\begin{array}{l}\text { Column, } \\
\text { ground }\end{array}$ & 136 & 136 & & & & & & 36 & 109 & 0.26 & 0.80 \\
\hline $\begin{array}{l}\text { Infill wall, } \\
\text { ground- } \\
\text { level } 1\end{array}$ & & & 822 & 989 & 1080 & 6206 & 11529 & 2940 & 19100 & 2.97 & 23.24 \\
\hline $\begin{array}{l}\text { Beam, } \\
\text { level } 1\end{array}$ & 96 & 136 & & & & & & 110 & 163 & 1.15 & 1.20 \\
\hline $\begin{array}{l}\text { Column, } \\
\text { level } 1\end{array}$ & 7 & $\begin{array}{l}78 \\
78\end{array}$ & & & & & & 90 & 124 & 1.25 & 1.59 \\
\hline Beam, roof & 103 & 139 & & & & & & 314 & 882 & 3.05 & 6.35 \\
\hline
\end{tabular}

Table 4-1-3 Summary of results of longitudinal wall and infill frame for Ringland Bros building

\begin{tabular}{|c|c|c|c|c|c|c|c|c|c|c|}
\hline \multirow[b]{2}{*}{$\begin{array}{l}\text { Member } \\
\text { Type }\end{array}$} & \multirow[b]{2}{*}{ 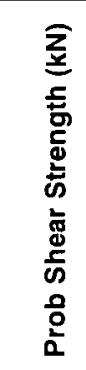 } & \multirow[b]{2}{*}{ 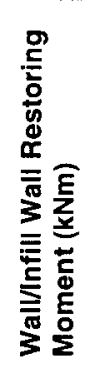 } & \multicolumn{4}{|c|}{ Strength of Infill Panels } & \multirow[b]{2}{*}{ 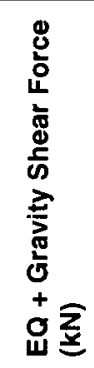 } & \multirow[b]{2}{*}{ 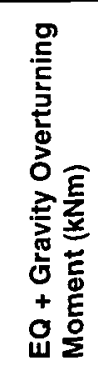 } & \multirow[b]{2}{*}{ 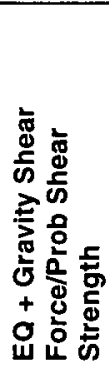 } & \multirow[b]{2}{*}{ 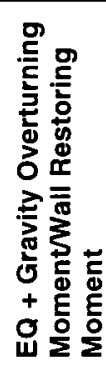 } \\
\hline & & & 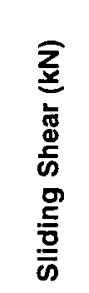 & 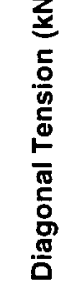 & 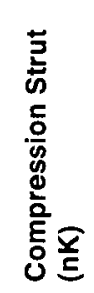 & 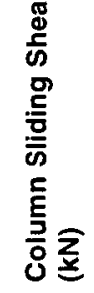 & & & & \\
\hline $\begin{array}{l}\text { Wall, } \\
\text { ground }\end{array}$ & 3170 & 3900 & & & & & 2180 & 12600 & 0.69 & 3.23 \\
\hline $\begin{array}{l}\text { Infill wall, } \\
\text { ground- } \\
\text { level } 1\end{array}$ & & 2268 & 12246 & 5572 & 21990 & 6329 & 761 & 9540 & 0.14 & 4.21 \\
\hline
\end{tabular}

\section{$\underline{\text { Discussion }}$}

Transverse: This frame, stiffened by unreinforced masonry infill panels, resists most of the seismic load applied. Table 4-1-2 suggests the infill wall should have rocked on its 
foundations before failing in shear (through sliding shear failure of the infill panel). The unusually high ratio is due to the high slenderness ratio of the infill wall and the small floor weight supported by the wall, reducing the restoring moment. There are no records of damage to support this outcome.

\section{Results Reliability Rating: B}

Longitudinal: The results suggest the reinforced concrete wall at ground floor may have rocked on its foundations. The infill frames in this direction did not resist much of the lateral load. The results reflect this; shear forces in the infill panels did not exceed the probable shear strength. Again there are no records of damage to support these outcomes.

\section{Results Reliability Rating: B}

\section{Gilberd \& Co}

\section{$\underline{\text { Seismic Loads }}$}

The variables for the seismic loads calculation are summarised in the table below.

Table 4-2-1 Summary of Seismic Load Variables for Gilberd \& Co. building (Transverse and Longitudinal)

\begin{tabular}{|l|l|l|l|}
\hline $\boldsymbol{\mu}$ & $\mathbf{C}$ & $\mathbf{W}_{\mathbf{t}}(\mathbf{k N})$ & $\mathbf{V}(\mathbf{k N})$ \\
\hline 1 & 1.14 & 3527 & 4021 \\
\hline
\end{tabular}

\section{$\underline{\text { Results }}$}

Table 4-2-2 Summary of results of transverse frame for Gilberd \& Co. building

\begin{tabular}{|c|c|c|c|c|c|c|c|c|c|}
\hline $\begin{array}{l}\text { Member } \\
\text { Type }\end{array}$ & 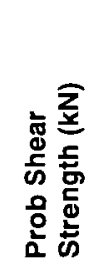 & 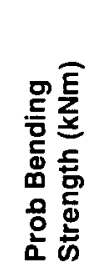 & 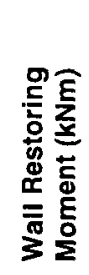 & 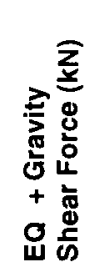 & 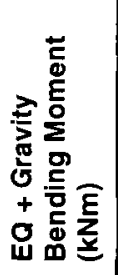 & 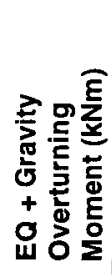 & 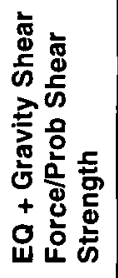 & 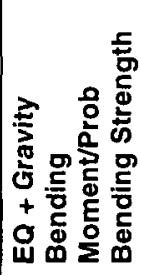 & 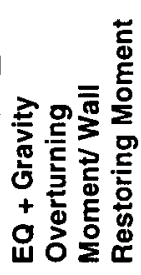 \\
\hline $\begin{array}{l}\text { Column, } \\
\text { ground }\end{array}$ & 109 & 163 & & 143 & 150 & & 1.31 & 0.92 & \\
\hline $\begin{array}{l}\text { Beam, } \\
\text { level } 1\end{array}$ & 241 & 378 & & 82 & 166 & & 0.34 & 0.44 & \\
\hline $\begin{array}{l}\text { Column, } \\
\text { level } 1\end{array}$ & 84 & 163 & & 253 & 212 & & 3.01 & 1.30 & \\
\hline Beam, roof & 602 & 736 & & 97 & 185 & & 0.16 & 0.25 & \\
\hline $\begin{array}{l}\text { Structural } \\
\text { walls, } \\
\text { ground }\end{array}$ & 1669 & & 232 & 1610 & & 4730 & 0.96 & & 20.39 \\
\hline
\end{tabular}


Table 4-2-3 Summary of results of longitudinal frame and walls for Gilberd \& Co building

\begin{tabular}{|c|c|c|c|c|c|c|c|c|c|}
\hline $\begin{array}{l}\text { Member } \\
\text { Type }\end{array}$ & 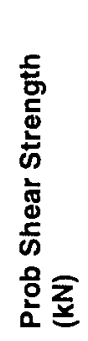 & 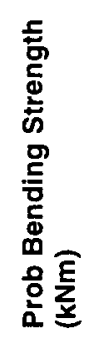 & 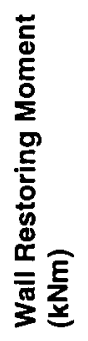 & 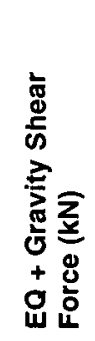 & 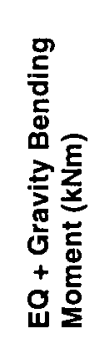 & 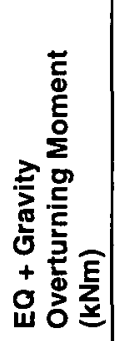 & 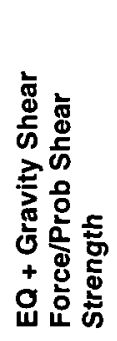 & 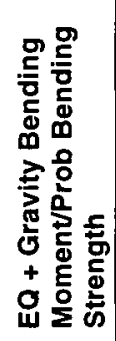 & 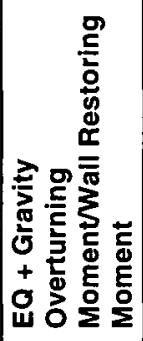 \\
\hline $\begin{array}{l}\text { Column, } \\
\text { ground }\end{array}$ & 225 & 288 & & 170 & 99 & & 0.76 & 0.34 & \\
\hline Beam, level 1 & 295 & 511 & & 127 & 165 & & 0.43 & 0.32 & \\
\hline $\begin{array}{l}\text { Column, } \\
\text { level } 1\end{array}$ & 214 & 288 & & 76 & 62 & & 0.36 & 0.22 & \\
\hline Beam, roof & 108 & 80 & & 25 & 21 & & 0.23 & 0.26 & \\
\hline $\begin{array}{l}\text { Structural } \\
\text { wall, end bay }\end{array}$ & 904 & & 133 & 255 & & 662 & 0.28 & & 4.98 \\
\hline
\end{tabular}

\section{$\underline{\text { Discussion }}$}

Transverse: The structural walls resisted most of the seismic loads at level 1 through overturning. The overturning moments of both walls exceeded the probable restoring moments indicating that the walls may have rocked. There are no records to verify this outcome. The ratios for the structural walls are unusually high because there is little floor weight supported by them, significantly reducing the restoring moments. The columns at Level 1 may have suffered some shear cracking though again there is no recorded evidence to support this.

\section{Results Reliability Rating: A}

Longitudinal: Table 4-2-3 indicates that the majority of the seismic load was resisted by the walls at each end bay that are stabilised by reinforced concrete spandrels. The overturning ratio of the end-bay walls would be reduced if the restoring moments and shear from and shear from the deep spandrels were accounted for.

\section{Results Reliability Rating: B}




\section{Conclusions}

The pilot analysis indicates the Gilberd \& Co building performed better in the transverse direction than predictions of wall overturning suggest. The lack of detailed recorded damage prevents any firm conclusions being drawn but there are no signs of the building having been damaged. The longitudinal primary lateral load resisting structure performed within the probable strength calculations, except for the end bays, acting as structural walls, rocking on their foundations.

The Ringland Bros building highlights some missing criteria in the Green Book, namely the sliding shear capacity of columns adjacent to infill panels (which were not critical), and restoring/overturning moments for infill-frames acting as walls.

The good actual seismic performance of these buildings overall indicates that the Green Book may be conservative, with some exceptions.

The findings from the pilot analysis suggest that some reinforced concrete frames and walls may have a greater capacity than current theory suggests, providing a basis for continuing the remaining analysis. 


\section{Final Analysis: Building Descriptions and Results}

\section{Building Description}

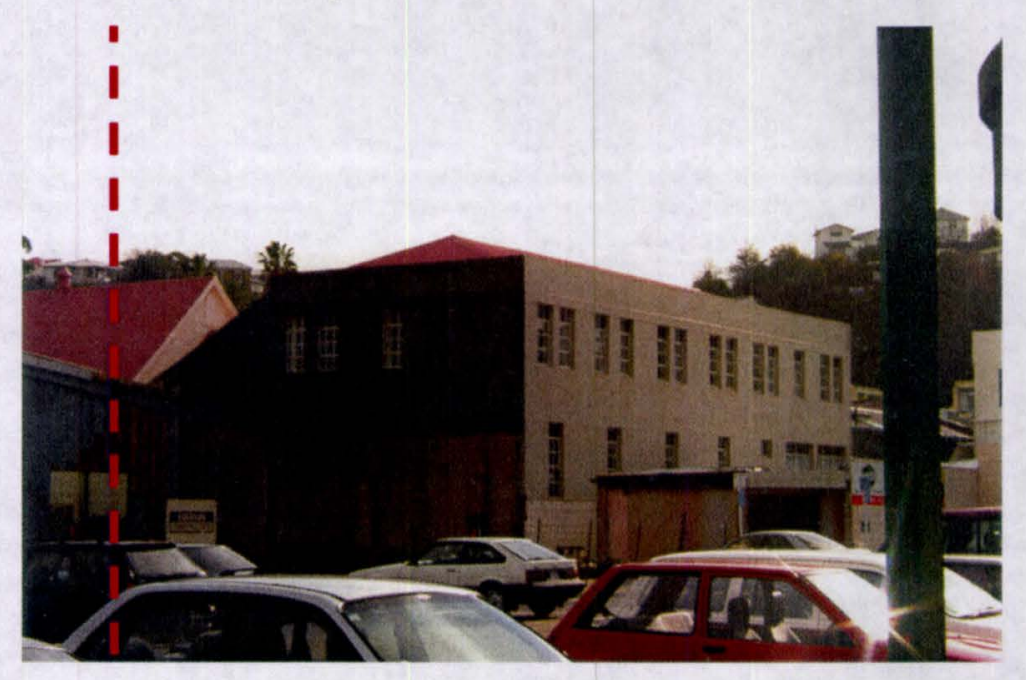

Building Name: Methodist Church Hall

Address: 3a Clive Square East, Napier

Date of Construction: 1929

\section{Primary lateral load resisting structural systems:}

Transverse - One reinforced concrete frame with unreinforced brick masonry (double skin cavity) infill panels.

Longitudinal - One reinforced concrete frame with unreinforced brick masonry (double skin cavity) infill panels.

Construction: A timber floor and roof with RSJ joists supporting the level 1 floor. The north wall is a brick party wall shared with a neighbouring property with two $0.305 \mathrm{~m} \times 0.305 \mathrm{~m}$ reinforced concrete columns at each end (part of the frames in the longitudinal direction).

Recorded notes on damage: Parapet down, (concrete) end walls unsafe, brick walls unsafe (Dowrick, 1998).

\section{Assumptions made in modelling:}

- Wall of staircase enclosure at South-west corner of building is modelled as an extra frame, though only a horizontal ring beam exists;

- The 3 bays of the Western longitudinal moment resisting frame that are almost fully glazed are very flexible compared to the bays with infill panels and thus do not contribute significantly (see Appendix B). 


\section{Results}

\section{$\underline{\text { Seismic Loads }}$}

The variables for the seismic load calculation are summarised in the table below.

Table 5-1-1 Summary of Seismic Load Variables for Methodist Church Hall building (Transverse and Longitudinal)

\begin{tabular}{|l|l|l|l|}
\hline $\boldsymbol{\mu}$ & $\mathbf{C}$ & $\mathbf{W}_{\mathbf{t}}(\mathbf{k N})$ & $\mathbf{V}(\mathbf{k N})$ \\
\hline 1 & 1.14 & 2669 & 3043 \\
\hline
\end{tabular}

\section{$\underline{\text { Results }}$}

Table 5-1-2 Summary of results of transverse frame for Methodist Church Hall building

\begin{tabular}{|c|c|c|c|c|c|c|c|c|c|}
\hline \multirow[b]{2}{*}{ Member Type } & \multirow[b]{2}{*}{ 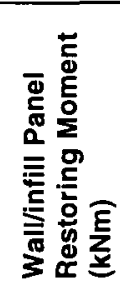 } & \multicolumn{4}{|c|}{ Strength of Infill Panels } & \multirow[b]{2}{*}{ 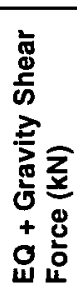 } & \multirow[b]{2}{*}{ 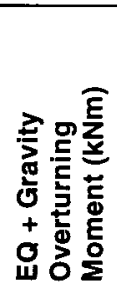 } & \multirow[b]{2}{*}{ 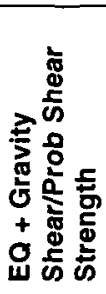 } & \multirow[b]{2}{*}{ 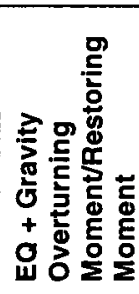 } \\
\hline & & 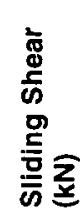 & 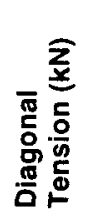 & 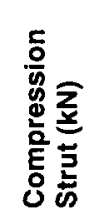 & 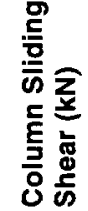 & & & & \\
\hline Infill wall, ground-level 1 & 9413 & 2089 & 1862 & 11945 & 2406 & 1430 & 20800 & 0.77 & 2.21 \\
\hline
\end{tabular}

Table 5-1-3 Summary of results of longitudinal frame for Methodist Church Hall building

\begin{tabular}{|c|c|c|c|c|c|c|c|c|c|c|c|c|c|}
\hline \multirow[b]{2}{*}{$\begin{array}{l}\text { Member } \\
\text { Type }\end{array}$} & \multirow[b]{2}{*}{ 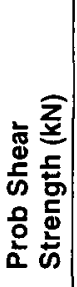 } & \multirow[b]{2}{*}{ 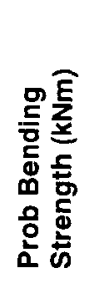 } & \multirow[b]{2}{*}{ 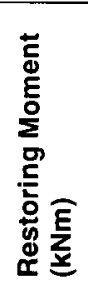 } & \multicolumn{4}{|c|}{ Strength of Infill Panels } & \multirow[b]{2}{*}{ 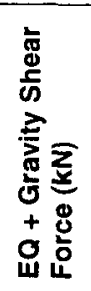 } & \multirow[b]{2}{*}{ 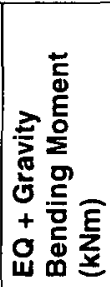 } & \multirow[b]{2}{*}{ 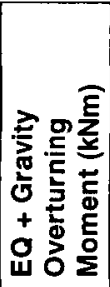 } & \multirow[b]{2}{*}{ 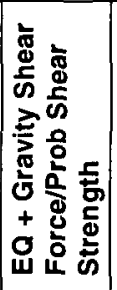 } & \multirow[b]{2}{*}{ 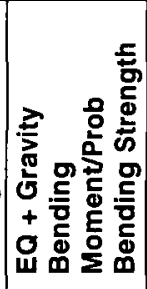 } & \multirow[b]{2}{*}{ 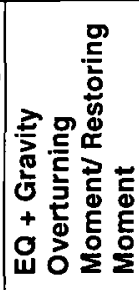 } \\
\hline & & & & 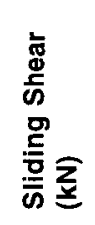 & 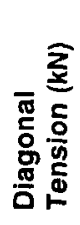 & 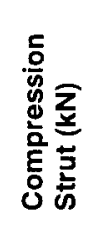 & 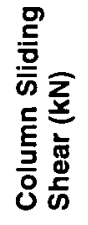 & & & & & & \\
\hline $\begin{array}{l}\text { Infill wa } \\
\text { ground }\end{array}$ & & & 4013 & 14957 & 788 & 11300 & 7168 & 2850 & & $\begin{array}{l}2080 \\
0\end{array}$ & 3.62 & & 5.18 \\
\hline $\begin{array}{l}\text { Column, } \\
\text { level } 1\end{array}$ & \begin{tabular}{|l|}
93 \\
\end{tabular} & 122 & & & & & & 221 & 226 & & 2.38 & 1.85 & \\
\hline $\begin{array}{l}\text { Beam, } \\
\text { roof }\end{array}$ & 83 & 89 & & & & & & 94 & 127 & & 1.13 & 1.43 & \\
\hline
\end{tabular}

\section{$\underline{\text { Discussion }}$}

Transverse: The wall in this direction should have rocked on its foundations. The recorded damage for this building might suggest that some damage occurred due to rocking.

\section{Results Reliability Rating: B}

Longitudinal: The wall at ground floor should have rocked and the results suggest failure of infill panels via Diagonal Tension Failure. The beams at level 1 should have failed in shear. The recorded damage does not identify these failure modes.

\section{Results Reliability Rating: B}




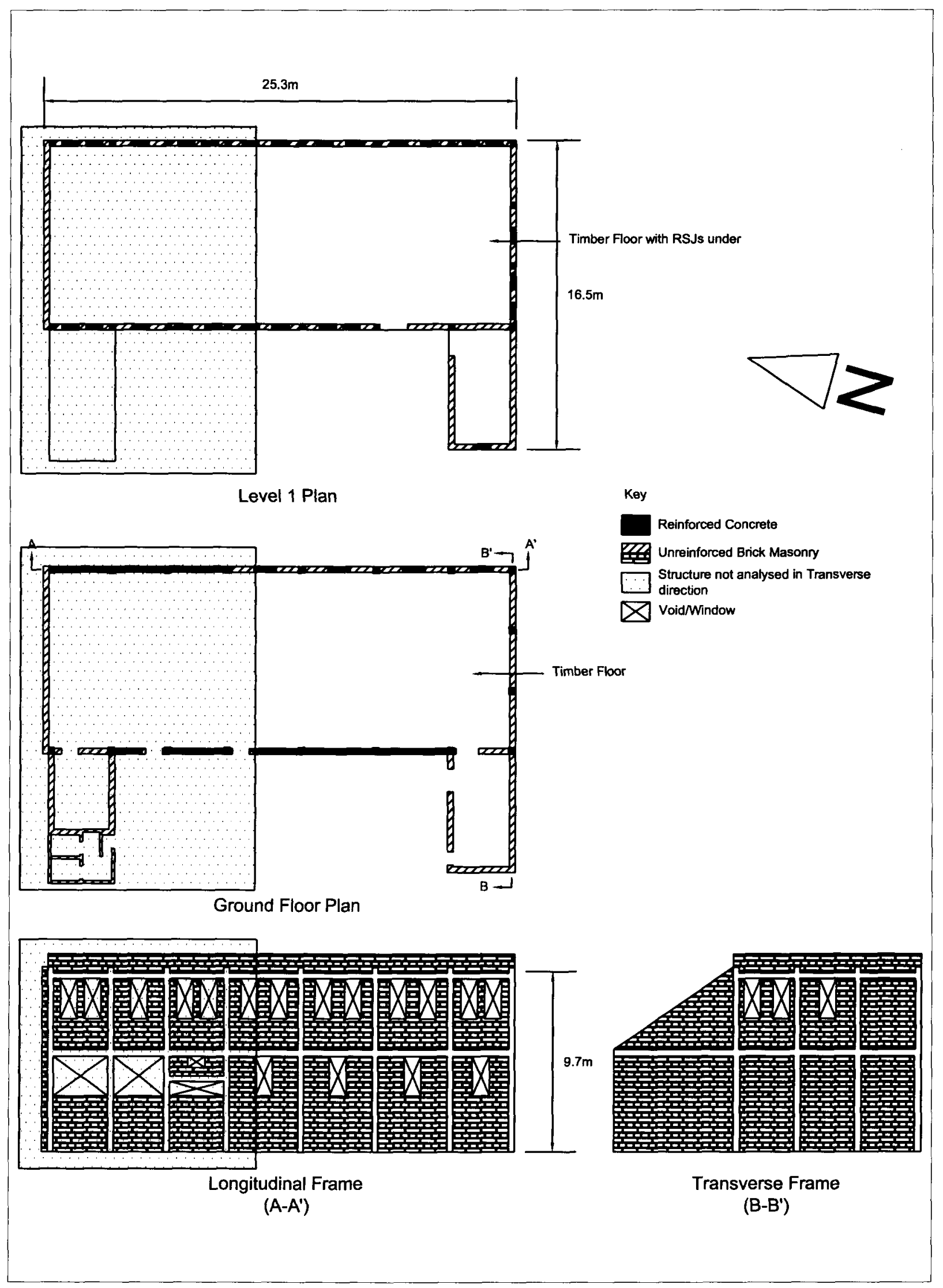

\section{Methodist Church Hall}




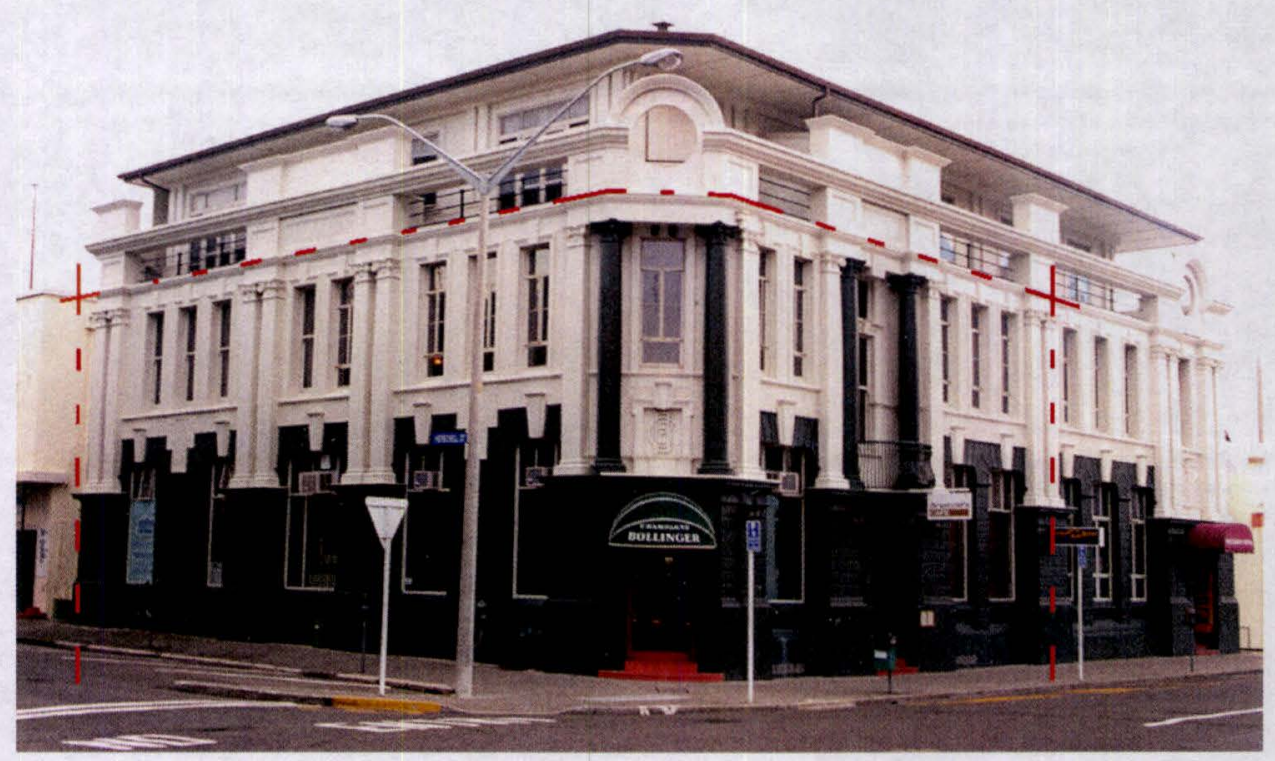

Building Name: Hawke's Bay County Council

Address: 6-10 Browning Street, Napier

Date of Construction: 1909

\section{Primary lateral load resisting structural systems:}

Transverse - Four reinforced concrete structural walls, two to level 1 only, two to roof level; spanning about one third the width of the building.

Longitudinal - Two full-length reinforced concrete structural walls, and one half-length reinforced concrete structural wall, all full height of the building.

Construction: Reinforced concrete floor and roof diaphragms with reinforced concrete moment resisting frames on both street facades (clad in unreinforced brick masonry).

Recorded notes on damage: 2 parapets gone after fire (Alexander Turnbull Library Photo \#G483381/2).

\section{Assumptions made in modelling:}

- Structural walls in both directions are assumed to resist most of the seismic load;

- The eccentric location of structural walls in the longitudinal direction leads to torsion effects, not accounted for in this study. 


\section{Results}

\section{$\underline{\text { Seismic Loads }}$}

The variables for the seismic load calculation are summarised in the table below.

Table 5-2-1 Summary of Seismic Load Variables for HB County Council building (Transverse and Longitudinal)

\begin{tabular}{|l|l|l|l|}
\hline $\boldsymbol{\mu}$ & $\mathbf{C}$ & $\mathbf{W}_{\mathbf{t}}(\mathbf{k N})$ & $\mathbf{V}(\mathbf{k N})$ \\
\hline 1 & 1.56 & 7250 & 11310 \\
\hline
\end{tabular}

\section{Results}

Table 5-2-2 Summary of results of transverse walls for HB County Council building

\begin{tabular}{|c|c|c|c|c|c|c|}
\hline Member Type & 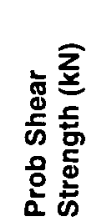 & 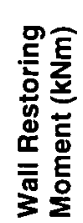 & 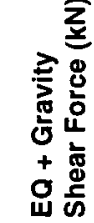 & 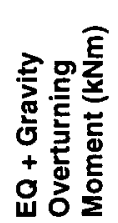 & 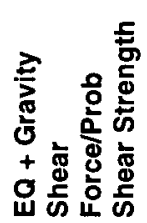 & 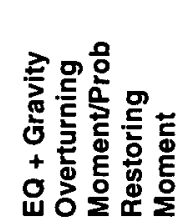 \\
\hline Structural wall, ground & 1390 & 960 & 1230 & 5690 & 0.88 & 5.93 \\
\hline Structural wall, ground-roof & 1390 & 1050 & 3580 & 25200 & 2.58 & 24.00 \\
\hline
\end{tabular}

Table 5-2-3 Summary of results of longitudinal wall for HB County Council building

\begin{tabular}{|c|c|c|c|c|c|c|}
\hline $\begin{array}{l}\text { Member } \\
\text { Type }\end{array}$ & 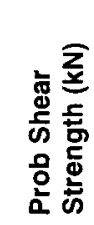 & 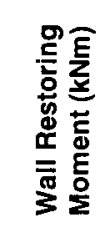 & 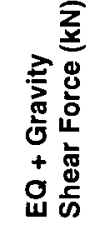 & 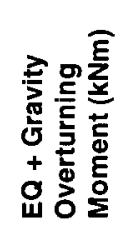 & 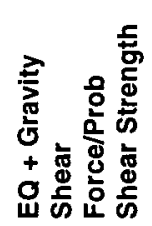 & 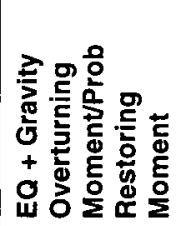 \\
\hline $\begin{array}{l}\text { Structural } \\
\text { wall, } \\
\text { ground- } \\
\text { roof }\end{array}$ & 5530 & 7830 & 3850 & 24900 & 0.70 & 3.18 \\
\hline
\end{tabular}

\section{Discussion}

Transverse: All structural walls in this direction should have rocked on their foundations. Though the records of damage suggest little structural damage occurred, the walls may still have rocked without observation.

\section{Results Reliability Rating: B}

Longitudinal: The structural wall that resists the seismic load in this direction should have rocked on its foundations. Again the records of damage suggest little structural damage occurred, though the walls may still have rocked without observation.

\section{Results Reliability Rating: B}




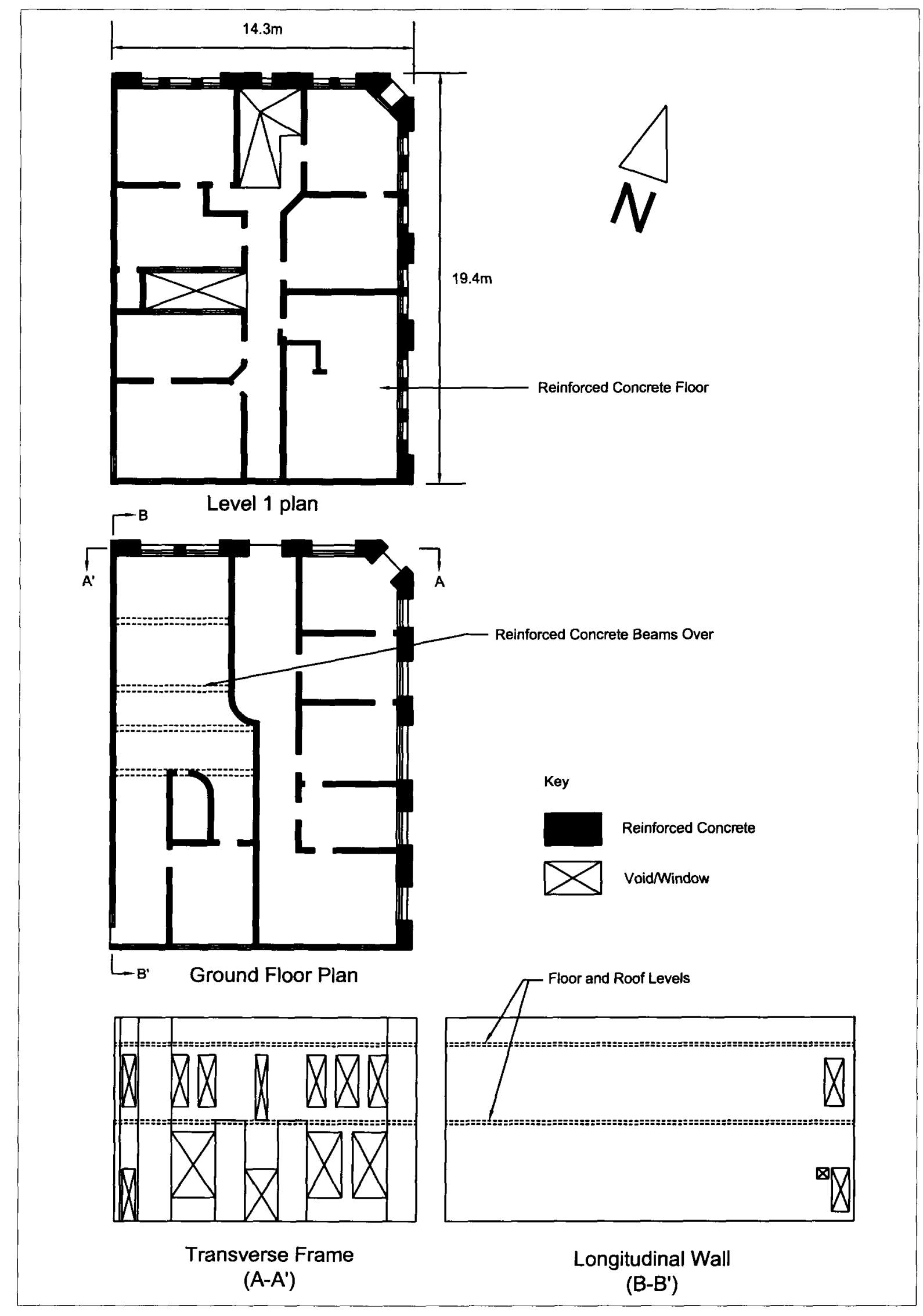

\section{Hawke's Bay County}




\section{Building Description}

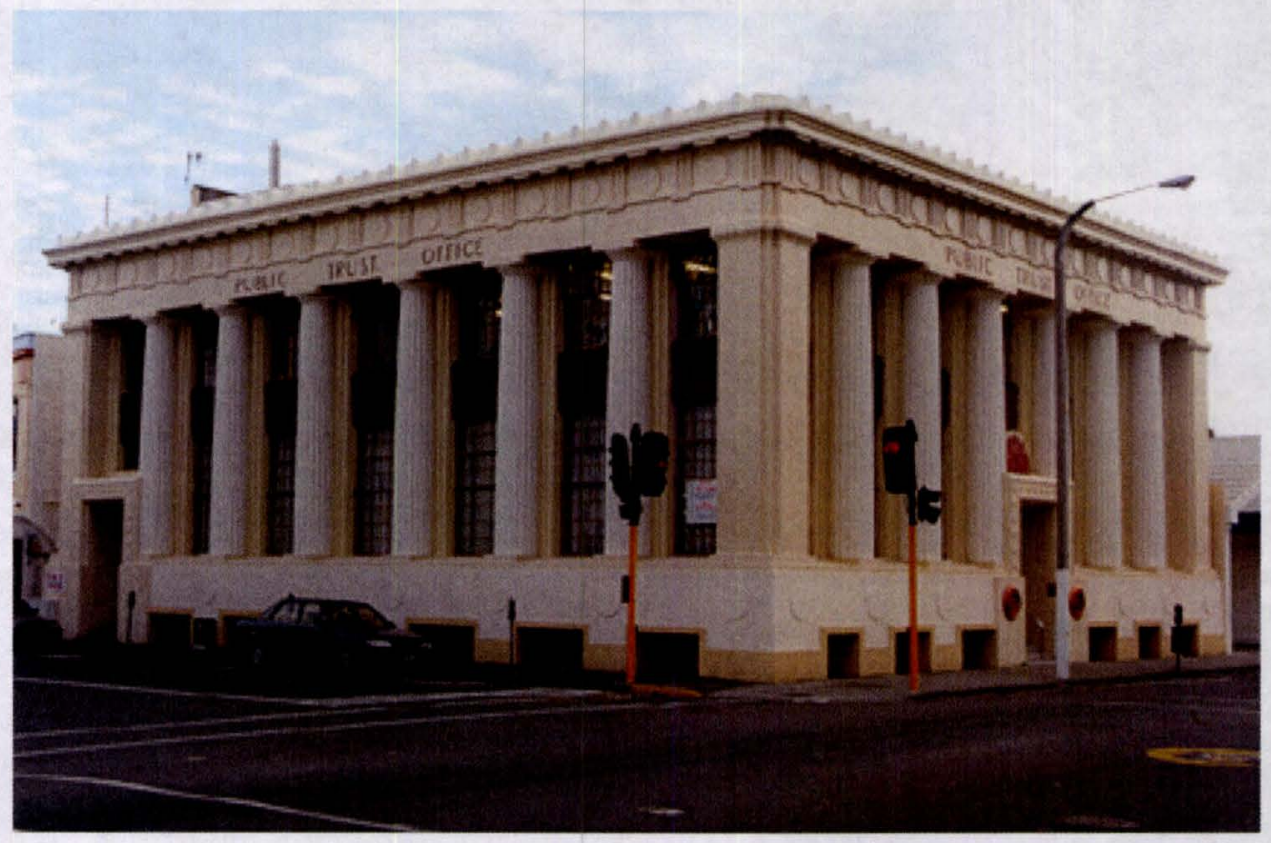

Building Name: Public Trust Office

Address: 42 Tennyson Street, Napier

Date of Construction: 1922

\section{Primary lateral load resisting structural systems:}

Transverse - One external reinforced concrete wall, full height of building, full width of building; one external two-storey reinforced concrete moment resisting frame.

Longitudinal - Two external reinforced concrete walls, full height of building over $60 \%$ wall length; one external two-storey reinforced concrete moment resisting frame.

Construction: Reinforced concrete floors and roof. Two reinforced concrete structural walls on West and South facades and reinforced concrete moment resisting frames on East and North facades.

Recorded notes on damage: Moderate. Badly cracked and unsafe. Cracks in the pillars on both street facades at first floor level (Dowrick, 1998). Large shear cracks in structural walls (Alexander Turnbull Library photos \#N37, \#N58). Damage to beams at roof level and exterior columns at both levels (inferred from Reinstatement drawings).

\section{Assumptions made in modelling:}

- The structural walls resist approximately $90 \%$ of the loads in both directions. The reinforced concrete moment resisting frames on the North and East facades resist the remainder but are not modelled; 
- Internal reinforced concrete walls are not allowed for, as these are structurally less significant than the external walls. (It should be noted that the location of the two external walls in the building might have led to some large torsion effects, not accounted for in this study.)

\section{Results}

\section{$\underline{\text { Seismic Loads }}$}

The variables for the seismic load calculation are summarised in the table below.

Table 5-3-1 Summary of Seismic Load Variables for Public Trust Office (Napier) building (Transverse and Longitudinal)

\begin{tabular}{|l|l|l|l|}
\hline $\boldsymbol{\mu}$ & $\mathbf{C}$ & $\mathbf{W}_{\mathbf{t}}(\mathbf{k N})$ & $\mathbf{V}(\mathbf{k N})$ \\
\hline 1 & 1.56 & 11100 & 17316 \\
\hline
\end{tabular}

\section{$\underline{\text { Results }}$}

Table 5-3-2 Summary of results of transverse wall for Public Trust Office (Napier) building

\begin{tabular}{|c|c|c|c|c|c|c|}
\hline Member Type & 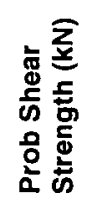 & 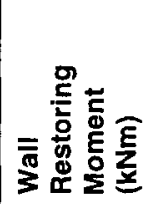 & 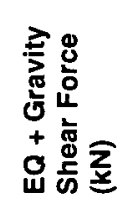 & 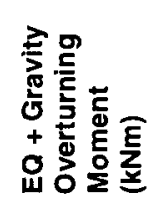 & 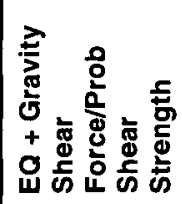 & 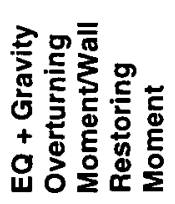 \\
\hline Structural wall, ground-level 1 & 7770 & 21841 & 14800 & $\overline{96300}$ & 1.90 & 4.41 \\
\hline
\end{tabular}

Table 5-3-3 Summary of results of longitudinal wall for Public Trust Office (Napier) building

\begin{tabular}{|c|c|c|c|c|c|c|}
\hline Member Type & 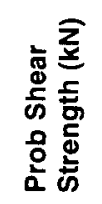 & 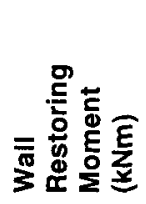 & 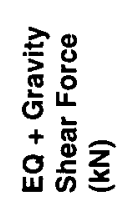 & 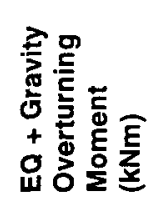 & 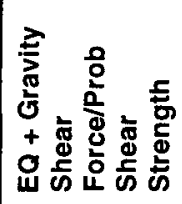 & 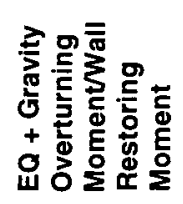 \\
\hline Structural wall, ground-levei 1 & 8898 & 33453 & 14800 & 96300 & 1.66 & 2.88 \\
\hline
\end{tabular}

\section{$\underline{\text { Discussion }}$}

Transverse: The structural wall on the South facade should have rocked. Some shear failure should have occurred. The damage records show this wall suffered shear failure.

\section{Results Reliability Rating: B}

Longitudinal: The structural wall on the West facade should have rocked. Some shear failure should have occurred. The damage records show this wall suffered shear failure.

\section{Results Reliability Rating: B}




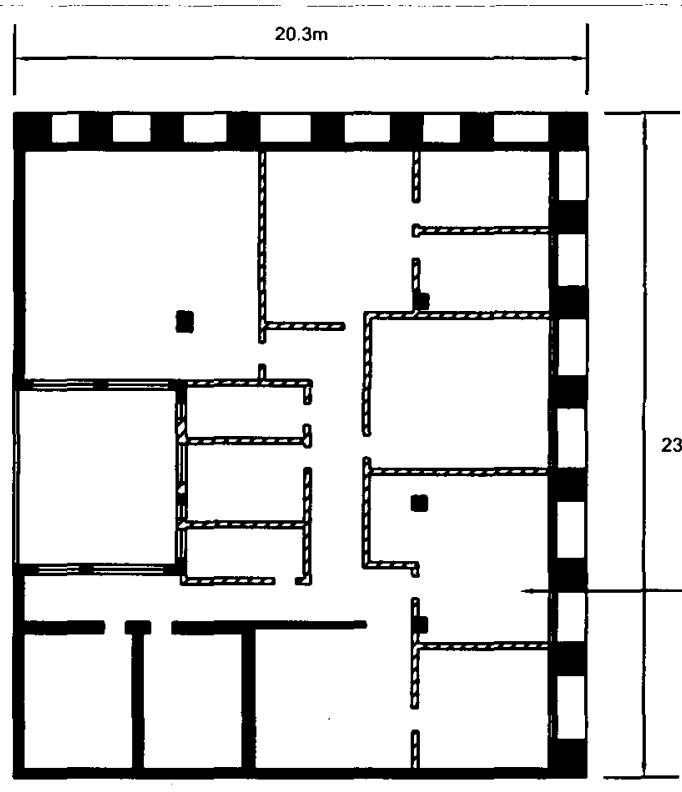

Reinforced Concrete Floor

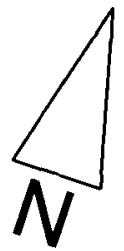

Level 1 Plan
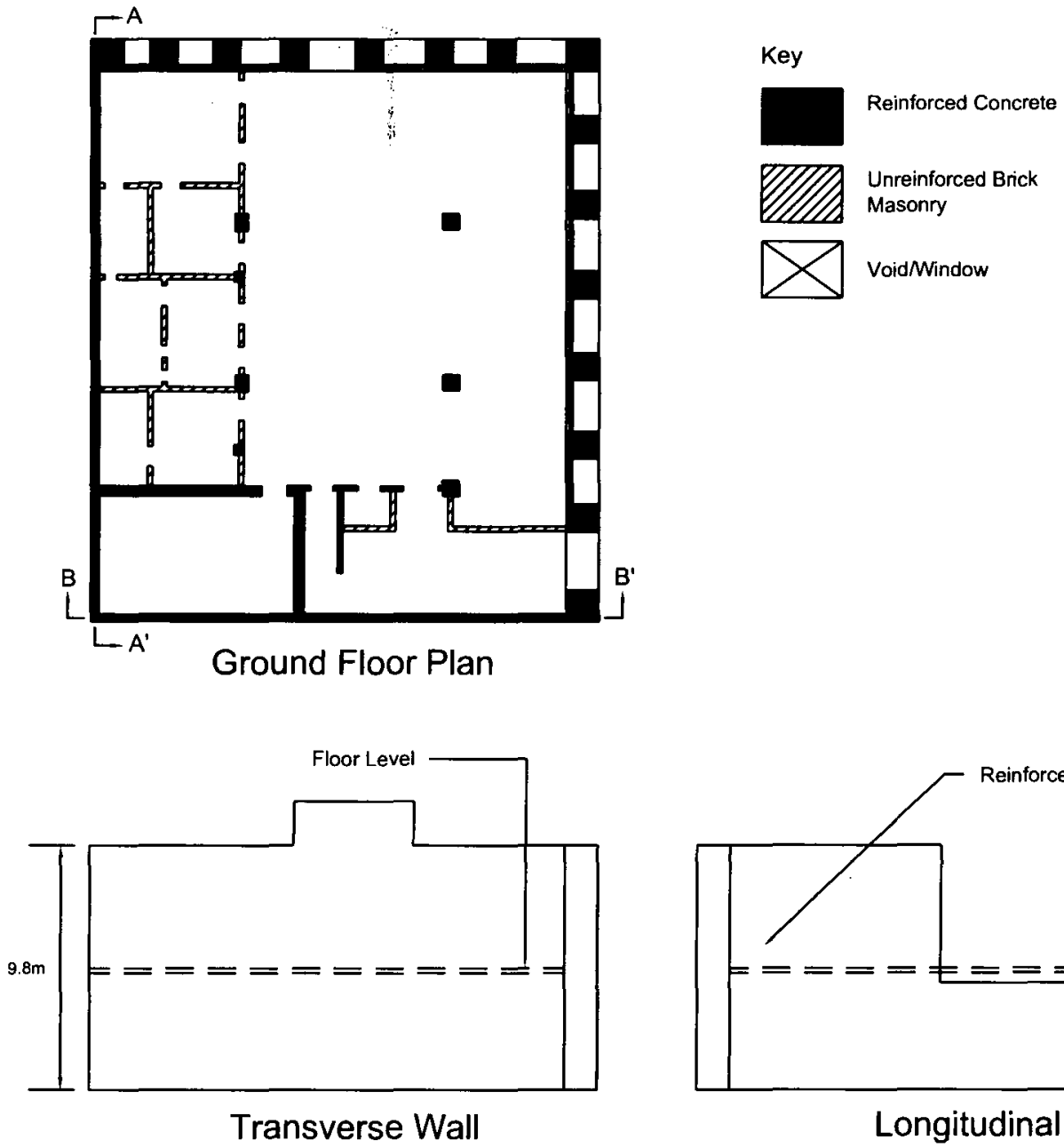

(B-B')

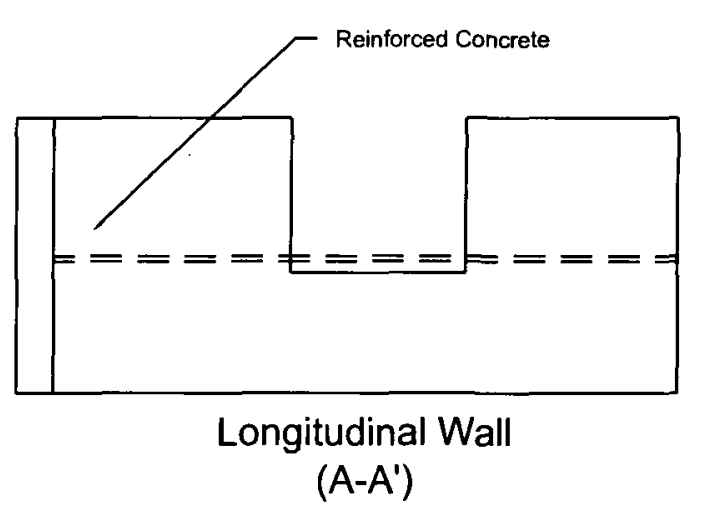

Public Trust Office (Napier) 


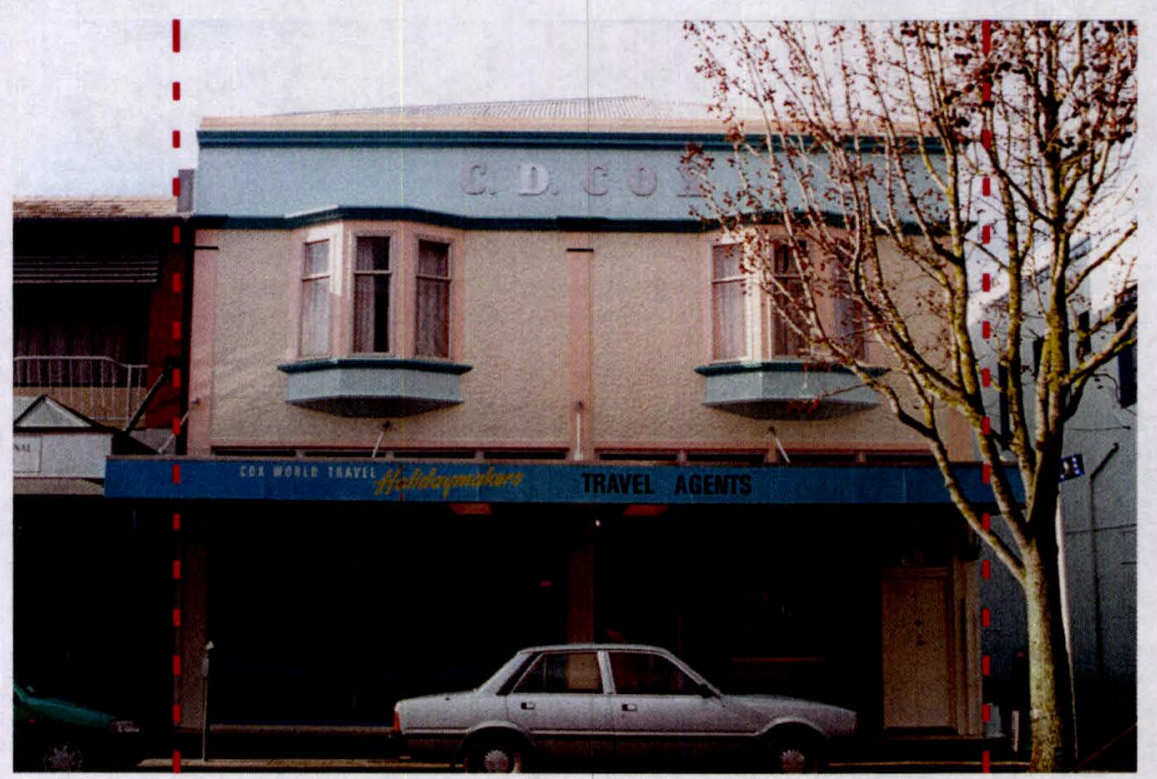

Building Name: Murdoch (JH) Bakery

Address: 14 Dalton Street, Napier

Date of Construction: 1925

\section{Primary lateral load resisting structural systems:}

Transverse - Six reinforced concrete structural walls.

Longitudinal - Four reinforced concrete structural walls.

Construction: Reinforced concrete floor and roof diaphragms with a second lightweight timber and corrugated steel roof.

Recorded notes on damage: Floor and wall cracked (Dowrick, 1998).

\section{Assumptions made in modelling:}

- The three moment resisting frames at ground floor are not modelled as they resist negligible seismic force compared to the structural walls.

\section{Results}

\section{$\underline{\text { Seismic Loads }}$}

The variables for the seismic load calculation are summarised in the table below.

Table 5-4-1 Summary of Seismic Load Variables for Murdoch Bakery building (Transverse and Longitudinal)

\begin{tabular}{|l|l|l|l|}
\hline $\boldsymbol{\mu}$ & $\mathbf{C}$ & $\mathbf{W}_{\mathbf{t}}(\mathbf{k N})$ & $\mathbf{V}(\mathbf{k N})$ \\
\hline 1 & 1.14 & 3777 & 4306 \\
\hline
\end{tabular}


$\underline{\text { Results }}$

Table 5-4-2 Summary of results of transverse walls for Murdoch Bakery building

\begin{tabular}{|c|c|c|c|c|c|c|}
\hline $\begin{array}{l}\text { Member } \\
\text { Type }\end{array}$ & 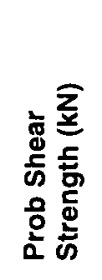 & 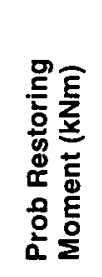 & 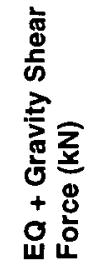 & 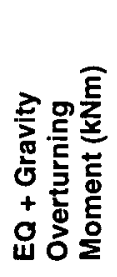 & 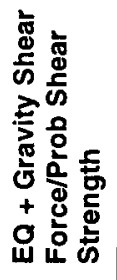 & 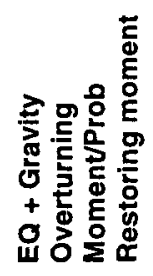 \\
\hline $\begin{array}{l}\text { Structural } \\
\text { wall, ground- } \\
\text { roof }\end{array}$ & 4510 & 3180 & 2170 & 12500 & 0.48 & 3.93 \\
\hline
\end{tabular}

Table 5-4-3 Summary of results of longitudinal walls for Murdoch Bakery building

\begin{tabular}{|c|c|c|c|c|c|c|}
\hline $\begin{array}{l}\text { Member } \\
\text { Type }\end{array}$ & 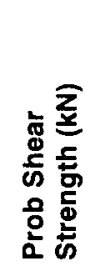 & 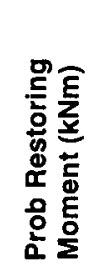 & 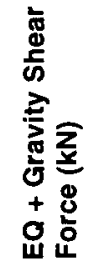 & 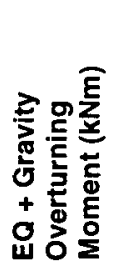 & 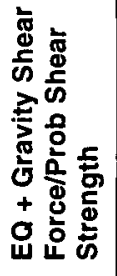 & 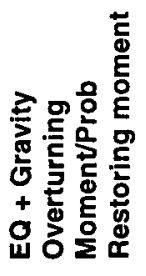 \\
\hline $\begin{array}{l}\text { Structural } \\
\text { wall, ground- } \\
\text { roof }\end{array}$ & 3080 & 3220 & 3500 & 22000 & 1.14 & 6.83 \\
\hline
\end{tabular}

\section{$\underline{\text { Discussion }}$}

Transverse: Some of the structural walls should have rocked on their foundations. This may have occurred without observation. There was apparently little structural damage in this direction.

\section{Results Reliability Rating: B}

Longitudinal: Most of the structural walls should have rocked on their foundations. Again this may have occurred without observation and without causing structural damage.

\section{Results Reliability Rating: B}




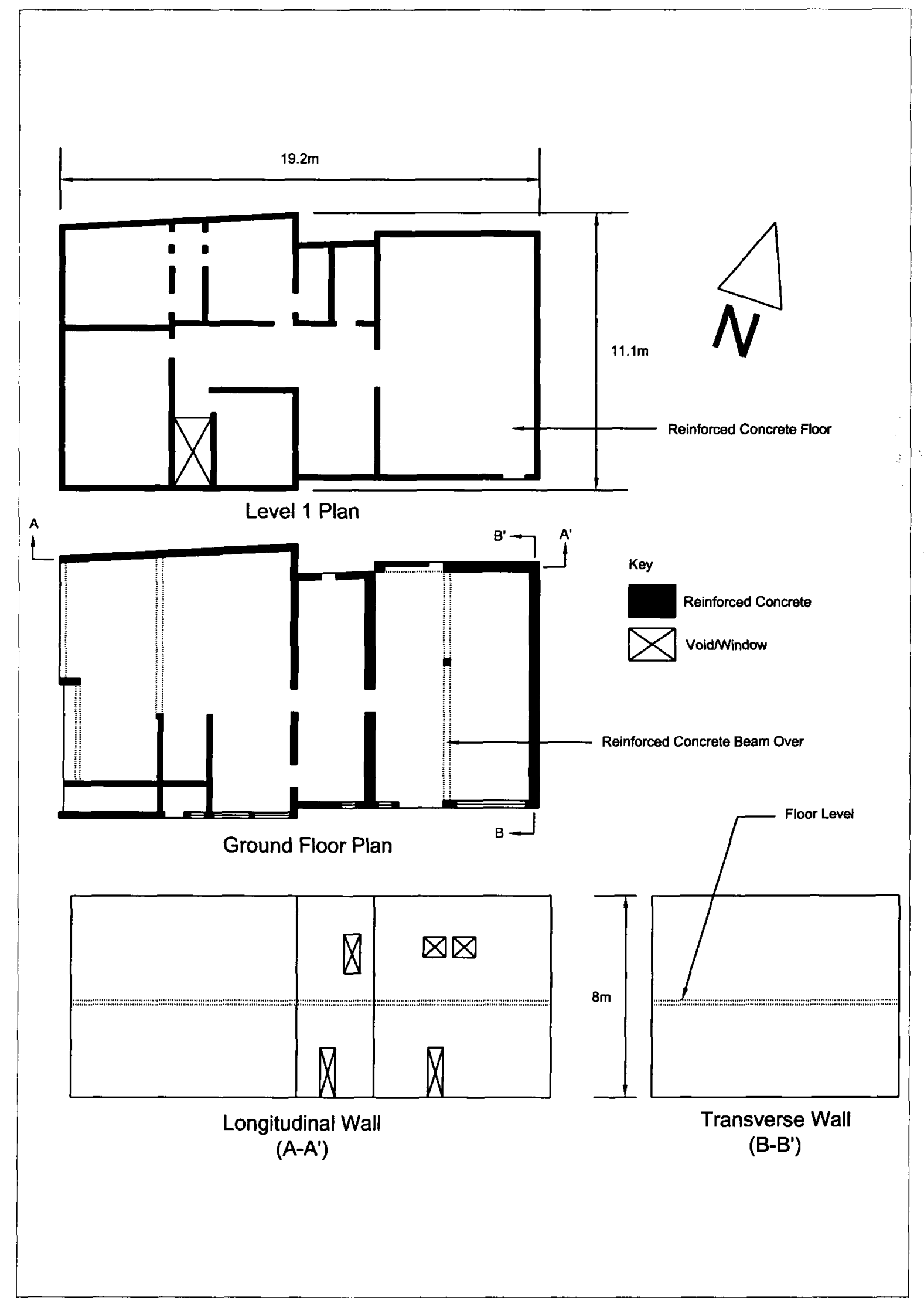

Murdoch (JH) Bakery 


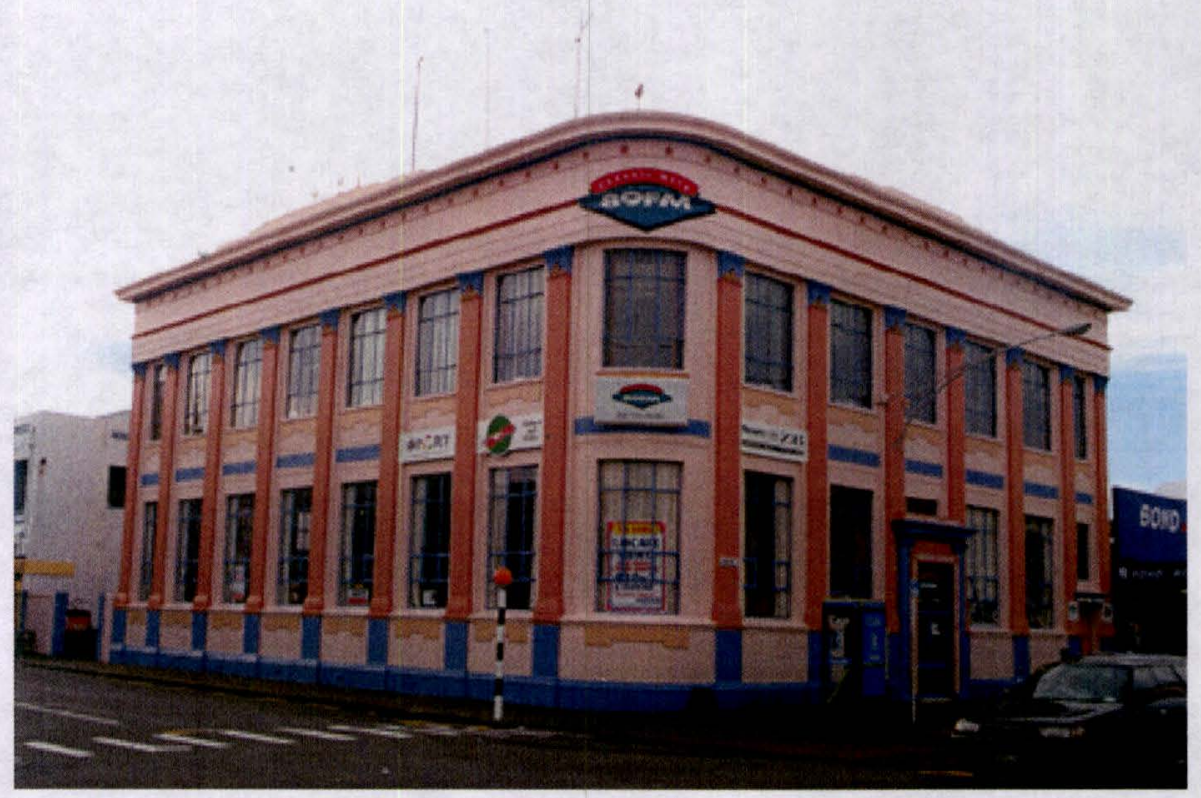

Building Name: Dalgety \& Co.

Address: 33-35 Dickens Street, Napier

Date of Construction: 1926

\section{Primary lateral load resisting structural systems:}

Transverse - Five reinforced concrete moment-resisting frames of which two are far stiffer. Longitudinal - One reinforced concrete structural wall.

Construction: Reinforced concrete floors and roof with two-way moment resisting frames and a structural wall to East facade. The North (rear) facade is a reinforced concrete wall with many penetrations.

Recorded notes on damage: Small cracks in finishing plaster (Dowrick, 1998); small chipping of concrete/plaster above main door (Alexander Turnbull Library photo \#N1).

\section{Assumptions made in modelling:}

- The North facade is assumed to act as a moment resisting frame;

- The footing width of the structural wall on East facade, not known, is assumed to be of similar proportions as the footings for walls in the Gilberd \& Co building;

- The moment resisting frames on the North and South facades are assumed to resist all of the seismic loading transversely. The frame on the North (rear) facades, created by the many penetrations in the wall, is assumed to have the same properties as the South (street) facade; 
- It should be noted that the location of the external wall and the stiff frame on the North facade in the building might have led to some large torsion effects, not accounted for in this study.

\section{Results}

\section{Seismic Loads}

The variables for the seismic load calculation are summarised in the table below.

Table 5-5-1 Summary of Seismic Load Variables for Dalgety \& Co. building (Transverse and Longitudinal)

\begin{tabular}{|l|l|l|l|}
\hline $\boldsymbol{\mu}$ & $\mathbf{C}$ & $\mathbf{W}_{\mathbf{t}}(\mathbf{k N})$ & $\mathbf{V}(\mathbf{k N})$ \\
\hline 1 & 1.14 & 10290 & 11731 \\
\hline
\end{tabular}

\section{$\underline{\text { Results }}$}

Table 5-5-2 Summary of results of transverse frame for Dalgety \& Co. building

\begin{tabular}{|c|c|c|c|c|c|c|}
\hline Member Type & 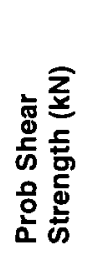 & 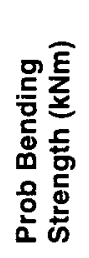 & 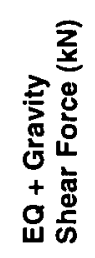 & 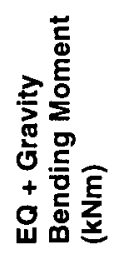 & 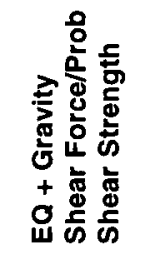 & 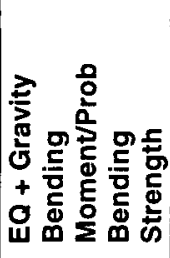 \\
\hline Column, ground & 622 & 467 & 1030 & 2580 & 1.66 & 5.52 \\
\hline Beam, level 1 & 645 & 564 & 1740 & 1550 & 2.70 & 2.75 \\
\hline Column, level 1 & 585 & 467 & 881 & 1440 & 1.51 & 3.08 \\
\hline Beam, roof & 645 & 371 & 715 & 368 & 1.11 & 0.99 \\
\hline
\end{tabular}

Table 5-5-3 Summary of results of longitudinal wall for Dalgety \& Co. building

\begin{tabular}{|c|c|c|c|c|c|c|}
\hline Member Type & 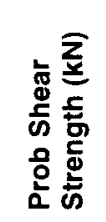 & 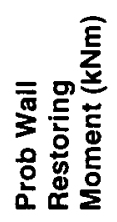 & 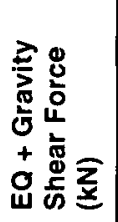 & 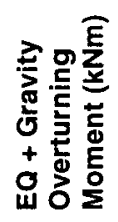 & 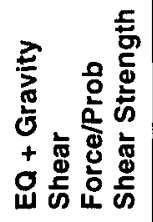 & 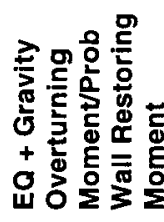 \\
\hline Structural wall, ground-roof & 19300 & 42900 & 13700 & 109250 & 0.71 & 2.55 \\
\hline
\end{tabular}

\section{Discussion}

Transverse: All beams and columns should have suffered some cracking due to yielding of reinforcement. The damage records show only superficial damage occurred.

\section{Results Reliability Rating: B}

Longitudinal: The wall should have rocked on its foundations. The records show only superficial damage.

\section{Results Reliability Rating: B}




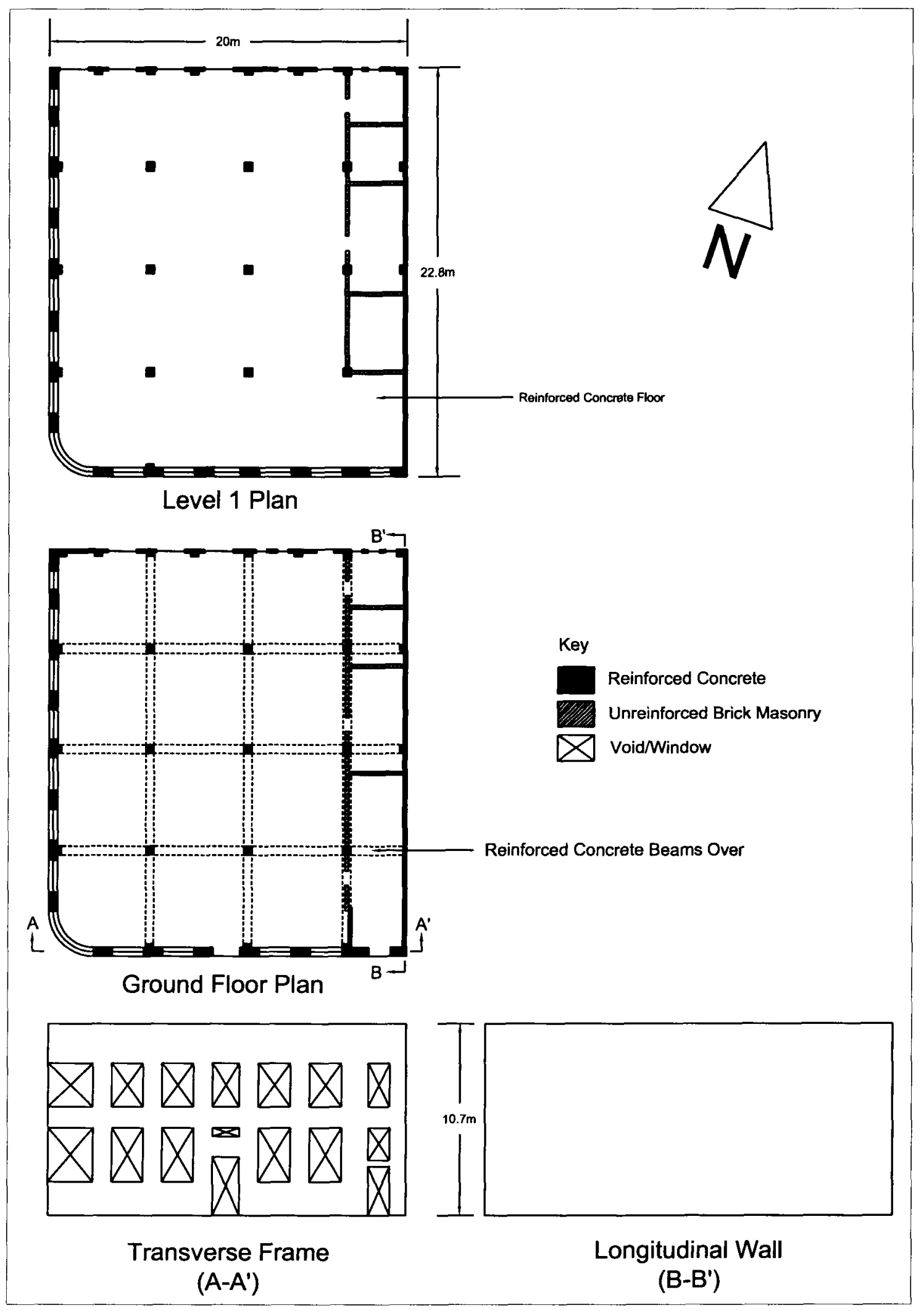

\section{Dalgety \& Co.}




\section{Building Description}

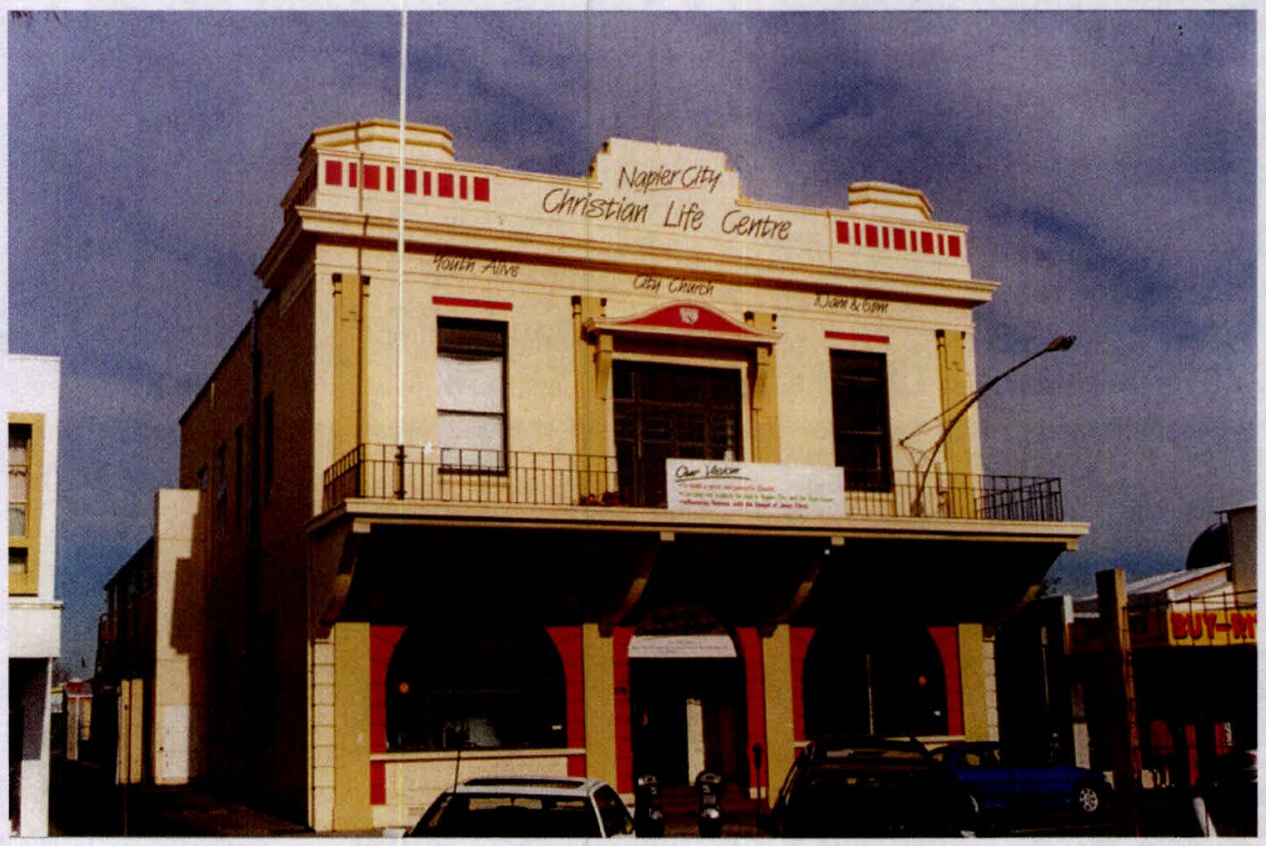

Building Name: Ancient Order of Foresters

Address: 50 Dickens Street

Date of Construction: $\mathrm{c} 1930$

\section{Primary lateral load resisting structural systems:}

Transverse - Seven reinforced concrete structural walls, four of which are at ground floor only.

Longitudinal - Two reinforced concrete structural walls and several deep column members of two reinforced concrete moment resisting frames.

Construction: Reinforced concrete floor and roof. Level 1 only extends $18 \mathrm{~m}$ from the street facade. The roof of the rear portion of the building is also of concrete.

Recorded notes on damage: No structural damage. No signs of damage (Alexander Turnbull Library photo \#48481/2)

\section{Assumptions made in modelling:}

- The seismic force in the longitudinal direction is applied to both structural walls and the moment resisting frames;

- The largest structural wall resists all the seismic force in the transverse direction (see Appendix B). The wall is assumed to be straight to simplify the model.

- The deeper column members of the two moment resisting frames in the longitudinal direction, located at the Dickens Street ends, are modelled as walls as they resist a significant amount of seismic load. 


\section{Results}

\section{$\underline{\text { Seismic Loads }}$}

The variables for the seismic load calculation are summarised in the table below.

Table 5-6-1 Summary of Seismic Load Variables for Ancient Order of Foresters building (Transverse and Longitudinal)

\begin{tabular}{|l|l|l|l|}
\hline $\boldsymbol{\mu}$ & $\mathbf{C}$ & $\mathbf{W}_{\mathbf{t}}(\mathbf{k N})$ & $\mathbf{V}(\mathbf{k N})$ \\
\hline 1 & 1.14 & 6082 & 6933 \\
\hline
\end{tabular}

$\underline{\text { Results }}$

Table 5-6-2 Summary of results of transverse walls for Ancient Order of Foresters building

\begin{tabular}{|c|c|c|c|c|c|c|}
\hline $\begin{array}{l}\text { Member } \\
\text { Type }\end{array}$ & 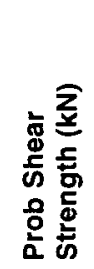 & 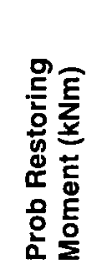 & 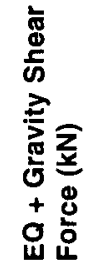 & 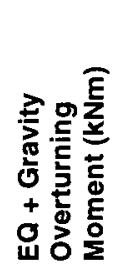 & 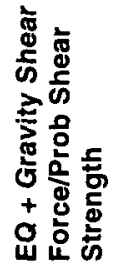 & 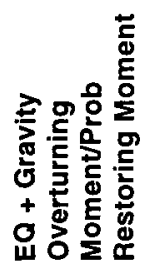 \\
\hline $\begin{array}{l}\text { Structural } \\
\text { wall, ground- } \\
\text { roof }\end{array}$ & 22500 & 7460 & 3100 & 18100 & 0.14 & 2.43 \\
\hline $\begin{array}{l}\text { Structural } \\
\text { wall, ground }\end{array}$ & 28400 & 10700 & 2850 & 11100 & 0.10 & 1.04 \\
\hline
\end{tabular}

Table 5-6-3 Summary of results of longitudinal walls for Ancient Order of Foresters building

\begin{tabular}{|c|c|c|c|c|c|c|}
\hline $\begin{array}{l}\text { Member } \\
\text { Type }\end{array}$ & 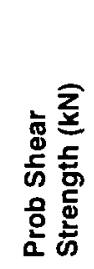 & 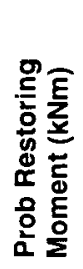 & 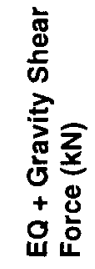 & 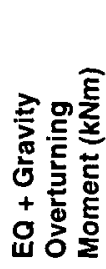 & 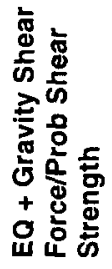 & 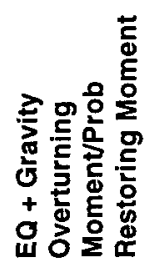 \\
\hline $\begin{array}{l}\text { Structural } \\
\text { wall, ground }\end{array}$ & 7580 & 557 & 2960 & 11600 & 0.39 & 20.83 \\
\hline
\end{tabular}

\section{Discussion}

Transverse: One structural wall in this direction should have rocked on its foundations. There was little structural damage recorded but the wall may have rocked without observation.

\section{Results Reliability Rating: B}

Longitudinal: The structural walls in this direction should all have rocked on their foundations. Again the walls may have rocked but without causing structural damage.

\section{Results Reliability Rating: B}




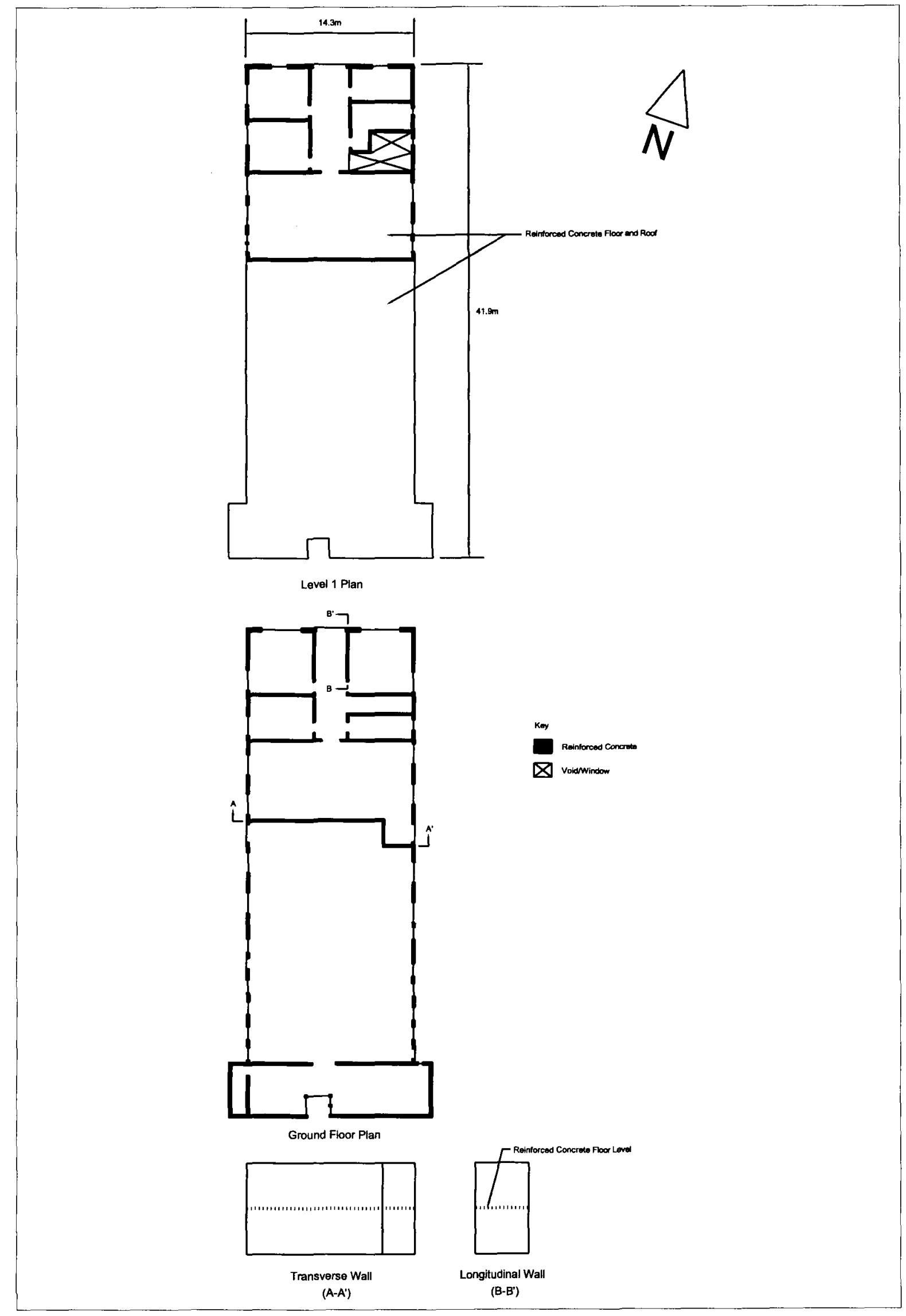

Ancient Order of Foresters 


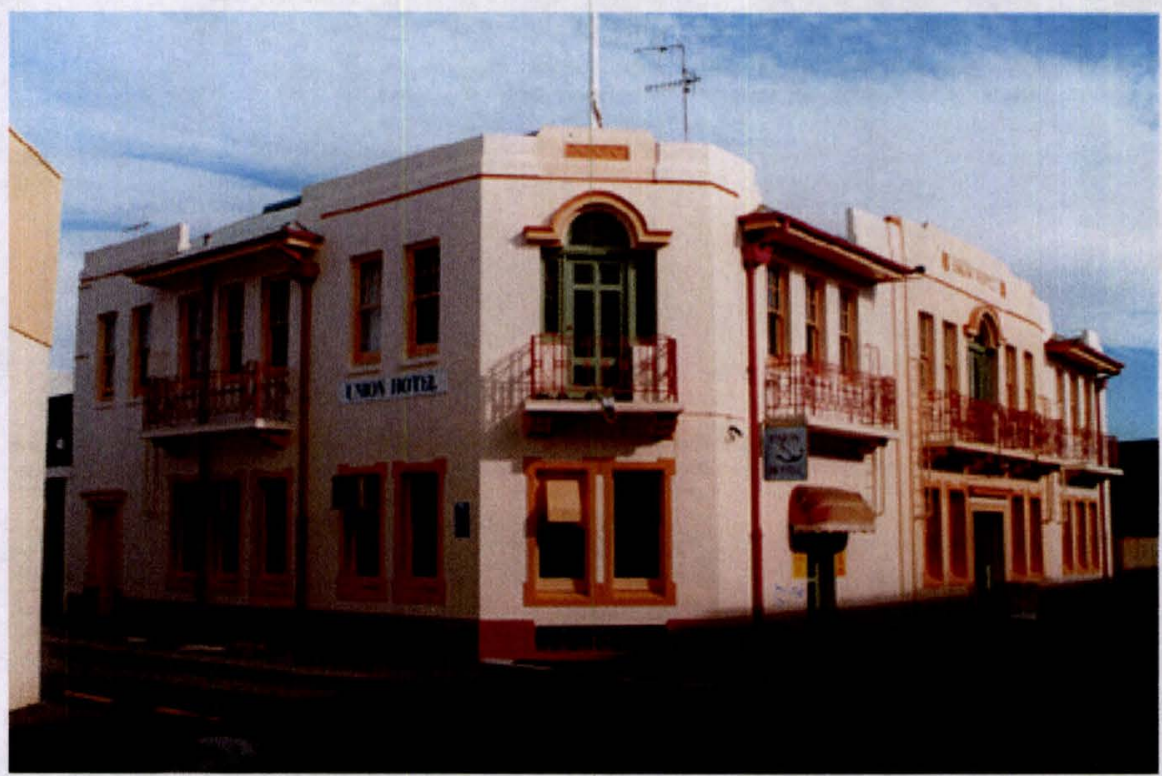

Building Name: Union Hotel

Address: 7 Waghorne Street, Port Ahuriri, Napier

Date of Construction: $\mathrm{c} 1930$

\section{Primary lateral load resisting structural systems:}

Transverse - Five reinforced concrete infill frames of varying lengths.

Longitudinal - Four reinforced concrete infill frames of varying lengths.

Construction: Reinforced concrete first floor and a lightweight timber framed roof with corrugated steel.

Recorded notes on damage: No structural damage.

\section{Assumptions made in modelling:}

- An adjoining unreinforced brick masonry structure, one storey in height with a lightweight timber framed roof, is not modelled, as the diaphragm cannot effectively transfer shear to the reinforced concrete moment resisting frames of the main building;

- Only moment resisting frames with infill panels that fill each bay completely are modelled as these will resist the majority of the seismic load; four in the transverse direction and five in the longitudinal direction;

- The structural action of the unreinforced masonry walls at first floor level is modelled as one horizontal force applied to the reinforced concrete infill walls at ground floor. 
$\underline{\text { Seismic Loads }}$

The variables for the seismic load calculation are summarised in the table below.

Table 5-7-1 Summary of Seismic Load Variables for Union Hotel building (Transverse and Longitudinal)

\begin{tabular}{|l|l|l|l|}
\hline $\boldsymbol{\mu}$ & $\mathbf{C}$ & $\mathbf{W}_{\mathbf{t}}(\mathbf{k N})$ & $\mathbf{V}(\mathbf{k N})$ \\
\hline 1 & 1.56 & 6808 & 10620 \\
\hline
\end{tabular}

$\underline{\text { Results }}$

Table 5-7-2 Summary of results of transverse infill walls for Union Hotel building

\begin{tabular}{|c|c|c|c|c|c|c|c|c|c|}
\hline \multirow[b]{2}{*}{ Member Type } & \multirow[b]{2}{*}{ 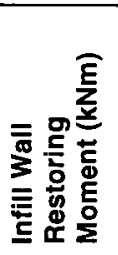 } & \multicolumn{4}{|c|}{ Strength of Infill Panels } & \multirow[b]{2}{*}{ 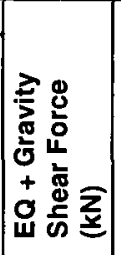 } & \multirow[b]{2}{*}{ 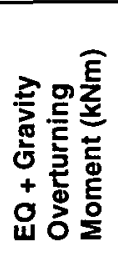 } & \multirow[b]{2}{*}{ 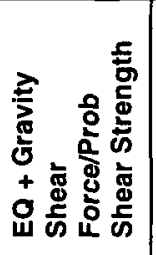 } & \multirow[b]{2}{*}{ 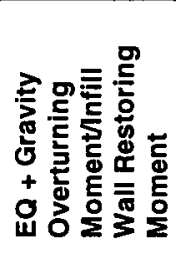 } \\
\hline & & 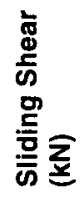 & 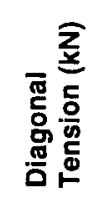 & 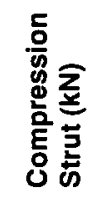 & 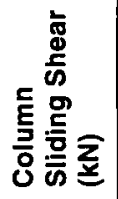 & & & & \\
\hline Infill w & 2620 & 2020 & 2580 & 13500 & 5370 & 4060 & 13400 & 2.01 & 5.11 \\
\hline Infill wall, ground & 1020 & 633 & 769 & 3090 & 2870 & 1740 & 5750 & 2.75 & 5.64 \\
\hline Infill wall, ground & 246 & 336 & 439 & 1600 & 1490 & 1250 & 4140 & 3.72 & 16.83 \\
\hline Infill wall, ground & 1840 & 1030 & 1450 & 4960 & 1670 & 1160 & 3820 & 1.13 & 2.08 \\
\hline
\end{tabular}

Table 5-7-3 Summary of results of longitudinal infill walls for Union Hotel building

\begin{tabular}{|c|c|c|c|c|c|c|c|c|c|}
\hline \multirow[b]{2}{*}{ Member Type } & \multirow[b]{2}{*}{ 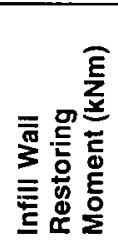 } & \multicolumn{4}{|c|}{ Strength of Infill Panels } & \multirow[b]{2}{*}{ 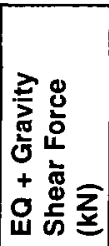 } & \multirow[b]{2}{*}{ 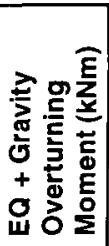 } & \multirow[b]{2}{*}{ 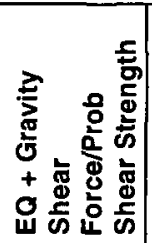 } & \multirow[b]{2}{*}{ 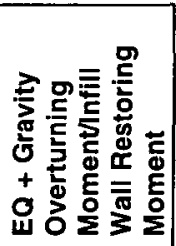 } \\
\hline & & 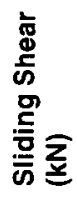 & 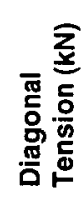 & 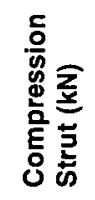 & 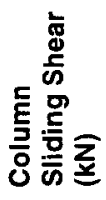 & & & & \\
\hline Infill wall, ground & 425 & 1050 & 1500 & 6700 & 2800 & 2990 & 9880 & 2.85 & 23.25 \\
\hline Infill wall, ground & 508 & 1080 & 1560 & 7100 & 4740 & 400 & 1320 & 0.37 & 2.60 \\
\hline Infill wall, ground & 506 & 648 & 936 & 3300 & 4210 & 347 & 1140 & 0.54 & 2.25 \\
\hline
\end{tabular}

\section{Discussion}

Transverse: All the infill walls should have rocked on their foundations and this may have prevented the expected shear failure by sliding shear through the infill panels. There was little or no structural damage to this building but the wall may have rocked on its foundations. The high ratios are due to the low floor weight, reducing the restoring moment.

\section{Results Reliability Rating: B}

Longitudinal: All infill walls should have rocked on their foundations. Again, the infill wall may have rocked without being observed to do so. The high ratios are due to the low floor weight supported by the wall, reducing the restoring moment.

Results Reliability Rating: B 


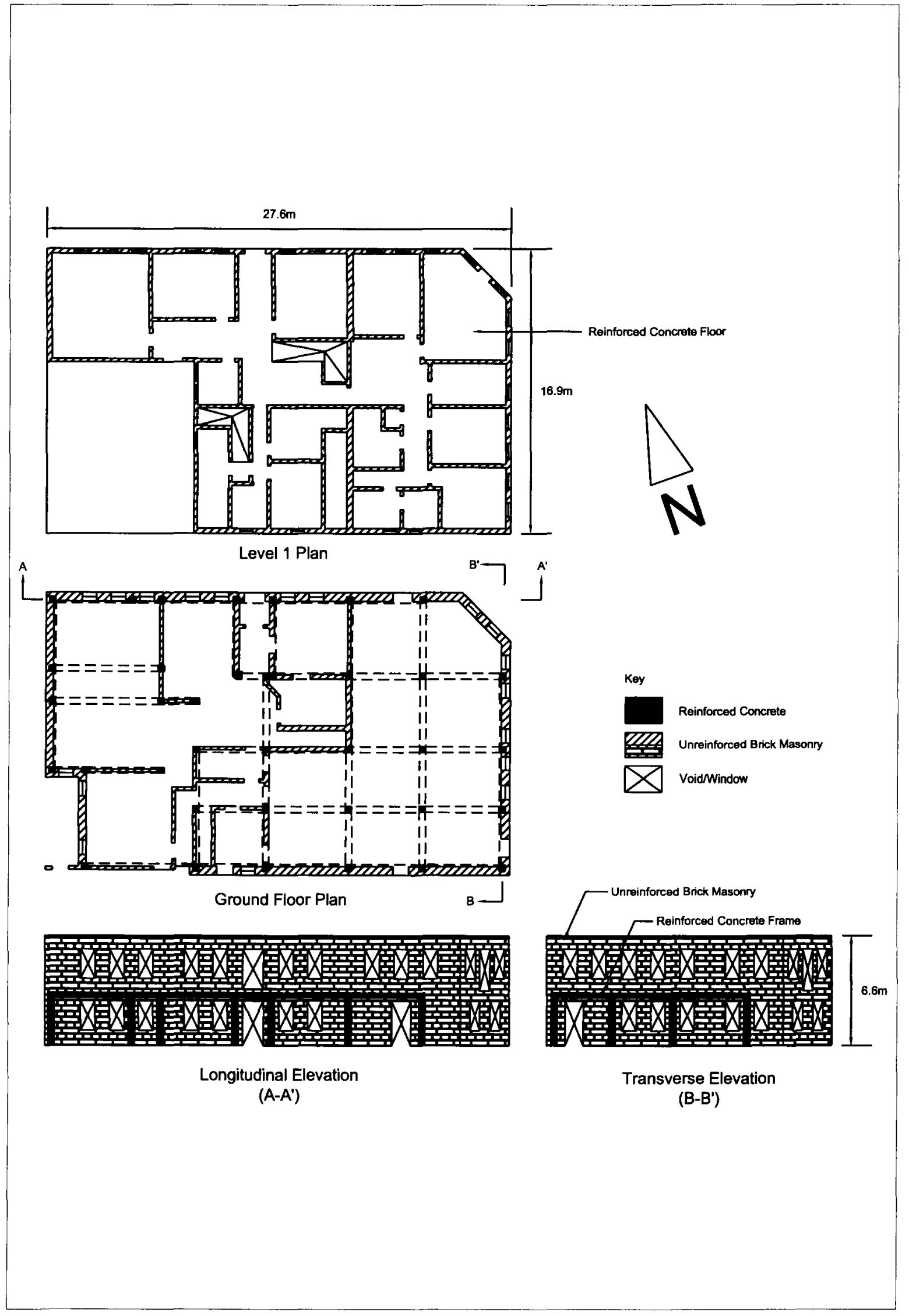

\section{Union Hotel}




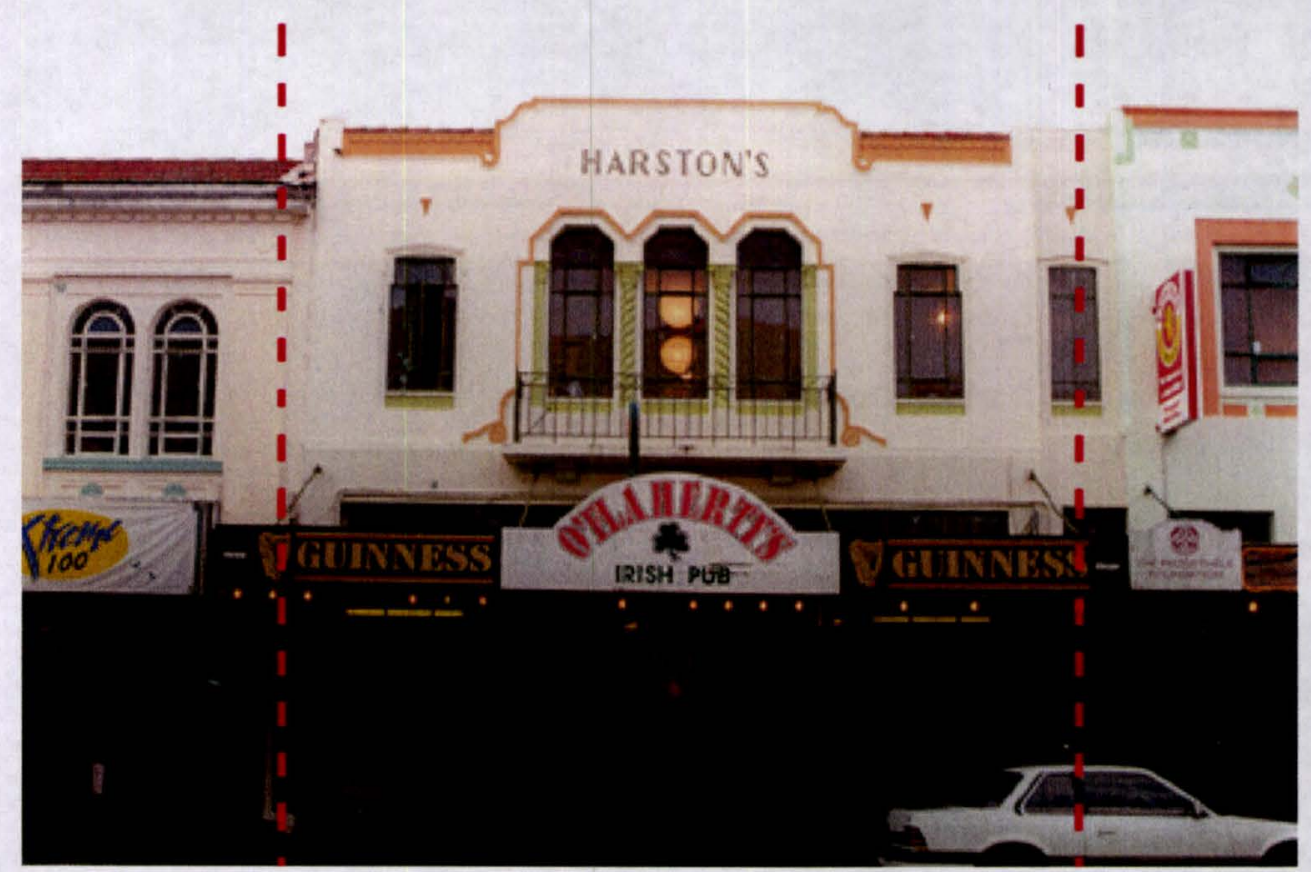

Building Name: Harston's Concert Hall

Address: 13-17 Hastings Street, Napier

Date of Construction: 1929

\section{Primary lateral load resisting structural systems:}

Transverse - Seven reinforced concrete, unreinforced brick infill, moment resisting frames at ground floor only.

Longitudinal - Two reinforced concrete moment resisting frames, one to roof level, the other at ground floor only.

Construction: Reinforced concrete floors. Lightweight timber frame roof with corrugated steel cladding. North wall is unreinforced brick masonry with reinforced concrete ring beams at each floor level.

Recorded notes on damage: No structural damage.

\section{Assumptions made in modelling:}

- Rear portion of building is not modelled as it is single storey and constructed of unreinforced brick masonry walls with a lightweight timber frame roof;

- The North wall, of URM, is assumed to resist 25 percent of the seismic load in the longitudinal direction. The two moment resisting frames resist the remainder;

- The transverse frames have brick masonry walls (on the North facade). The walls are modelled as brick pin-jointed columns. 


\section{Results}

\section{$\underline{\text { Seismic Loads }}$}

The variables for the seismic load calculation are summarised in the table below.

Table 5-8-1 Summary of Seismic Load Variables for Harston's Concert Hall building (Transverse and Longitudinal)

\begin{tabular}{|l|l|l|l|}
\hline $\boldsymbol{\mu}$ & $\mathbf{C}$ & $\mathbf{W}_{\mathbf{t}}(\mathbf{k N})$ & $\mathbf{V}(\mathbf{k N})$ \\
\hline 1 & 1.56 & 2951 & 4604 \\
\hline
\end{tabular}

\section{$\underline{\text { Results }}$}

Table 5-8-2 Summary of results of transverse frame for Harston's Concert Hall building

\begin{tabular}{|c|c|c|c|c|c|c|}
\hline Member Type & 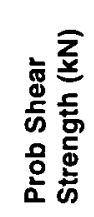 & 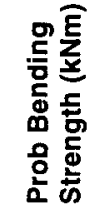 & 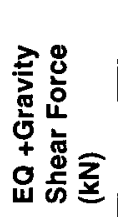 & 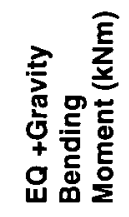 & 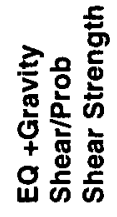 & 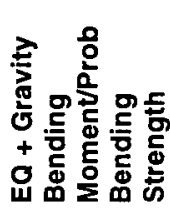 \\
\hline Column, ground & 164 & 147 & 458 & 1050 & 2.79 & 7.14 \\
\hline Beam, level 1 & 124 & 117 & 438 & 798 & 3.53 & 6.82 \\
\hline Column, level 1 & 169 & 147 & 264 & 705 & 1.56 & 4.80 \\
\hline Beam, roof & 124 & 117 & 44 & 375 & 0.35 & 3.21 \\
\hline
\end{tabular}

Table 5-8-3 Summary of results of longitudinal frame for Harston's Concert Hall building

\begin{tabular}{|c|c|c|c|c|c|c|c|c|c|}
\hline \multirow[b]{2}{*}{$\begin{array}{l}\text { Member } \\
\text { Type }\end{array}$} & \multirow[b]{2}{*}{ 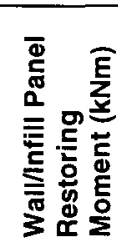 } & \multicolumn{4}{|c|}{ Strength of Infill Panels } & \multirow[b]{2}{*}{ 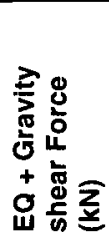 } & \multirow[b]{2}{*}{ 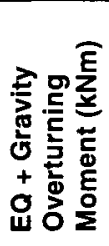 } & \multirow[b]{2}{*}{ 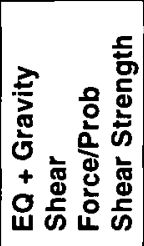 } & \multirow[b]{2}{*}{ 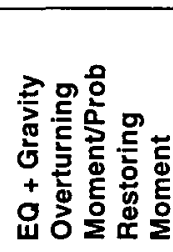 } \\
\hline & & 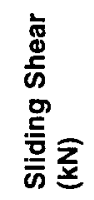 & 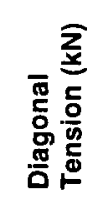 & 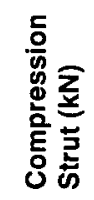 & 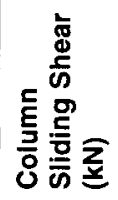 & & & & \\
\hline $\begin{array}{l}\text { Infill wall, } \\
\text { ground- } \\
\text { level } 1\end{array}$ & 11900 & 1464 & 1649 & 4951 & 2512 & 1030 & 15700 & 0.70 & 1.32 \\
\hline $\begin{array}{l}\text { Infill wall, } \\
\text { ground }\end{array}$ & 7788 & 1420 & 1590 & 5194 & 2409 & 1030 & 4440 & 0.73 & 0.57 \\
\hline
\end{tabular}

\section{Discussion}

Transverse: The columns at ground floor, the columns at level 1 and beams at roof level should all fail in bending first. There are no records of damage to verify these outcomes.

\section{Results Reliability Rating: C}

Longitudinal: The results indicate that the two-storey infill wall should have rocked on its foundations. Though there are no records of damage to verify this outcome, this may have occurred unobserved.

\section{Results Reliability Rating: C}




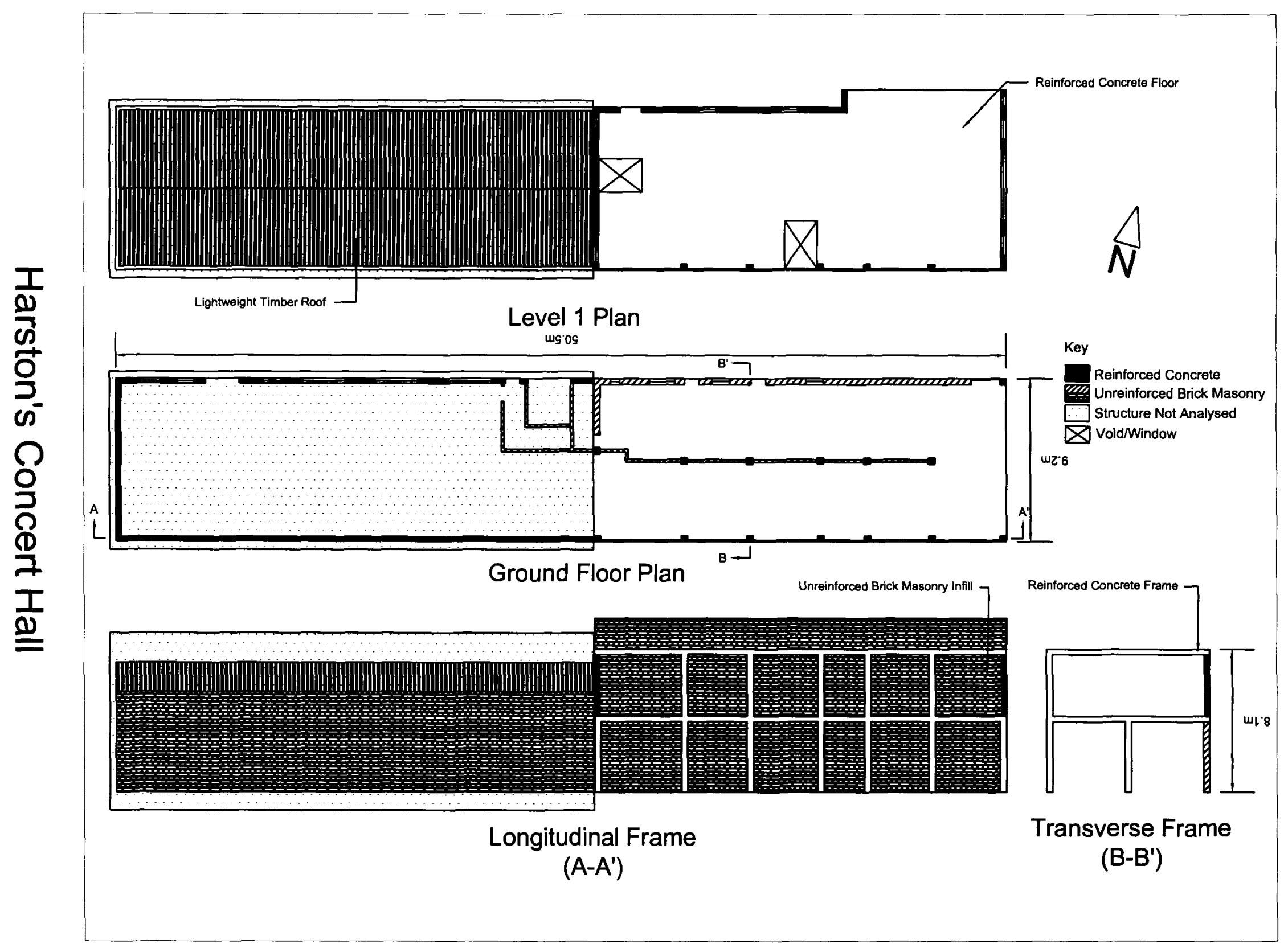




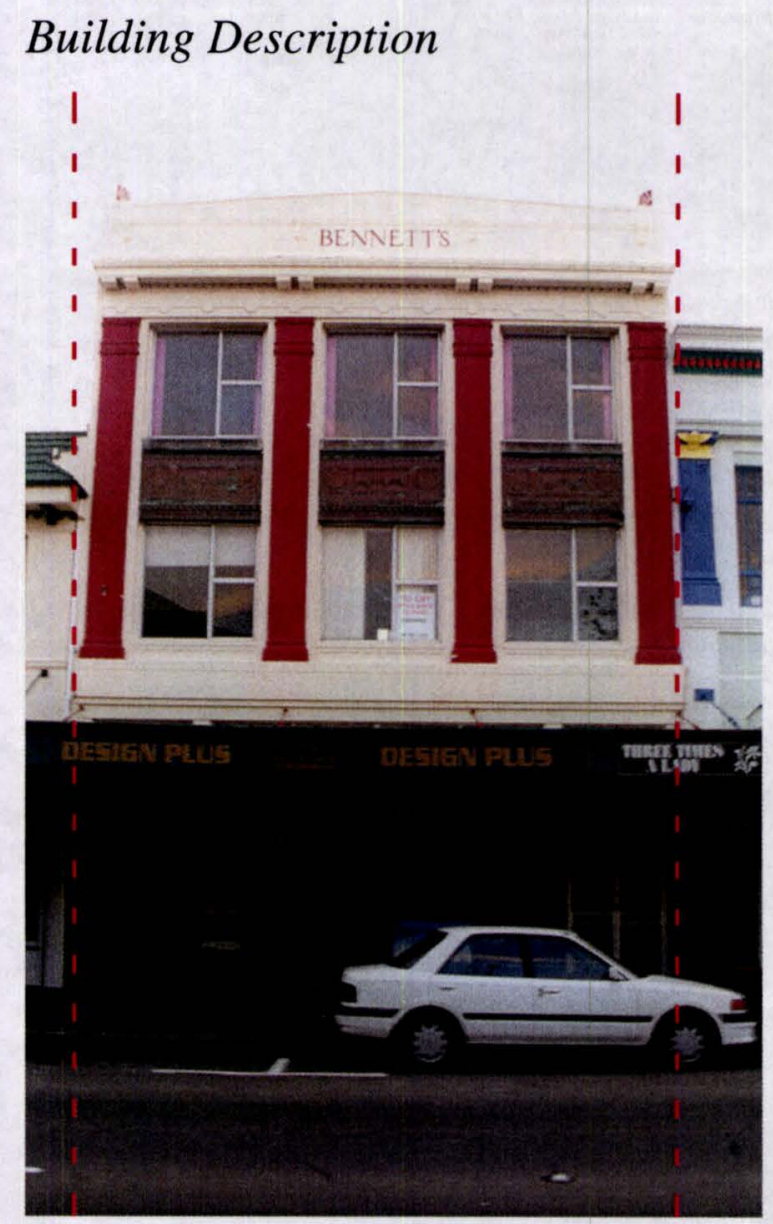

Building Name: Bennett Building

Address: 61-63 Hastings Street, Napier

Date of Construction: 1929

\section{Primary lateral load resisting structural systems:}

Transverse - Four reinforced concrete moment resisting frames.

Longitudinal - Two reinforced concrete structural walls on the boundary.

Construction: Lightweight timber floor and lightweight timber and corrugated steel roof. The building is three floors plus a basement.

Recorded notes on damage: Plaster lost from side-walls (Dowrick, 1998). Timber floor burnt out during fire (Bennett, Q., 1999, pers. comm.).

\section{Assumptions made in modelling:}

- The single penetration in one of the structural walls in the longitudinal direction is not included in the model as it does not influence the results significantly; 
- The basement is ignored. The perimeter walls and frames, the primary lateral load resisting structure, sit on perimeter walls adjacent to solid ground (with the exception of the west facade).

\section{Results}

\section{$\underline{\text { Seismic Loads }}$}

The variables for the seismic load calculation are summarised in the table below.

Table 5-9-1 Summary of Seismic Load Variables for Bennett building (Transverse and Longitudinal)

\begin{tabular}{|l|l|l|l|}
\hline $\boldsymbol{\mu}$ & $\mathbf{C}$ & $\mathbf{W}_{\mathbf{t}}(\mathbf{k N})$ & $\mathbf{V}(\mathbf{k N})$ \\
\hline $\mathbf{1}$ & 1.56 & 3198 & 4989 \\
\hline
\end{tabular}

\section{$\underline{\text { Results }}$}

Table 5-9-2 Summary of results of transverse frames for Bennett building

\begin{tabular}{|c|c|c|c|c|c|c|}
\hline Member Type & 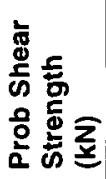 & 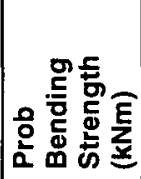 & 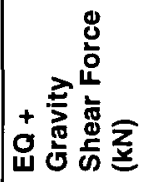 & 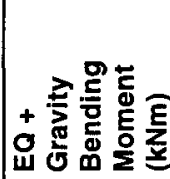 & 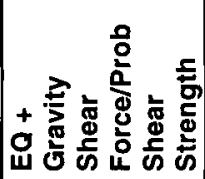 & 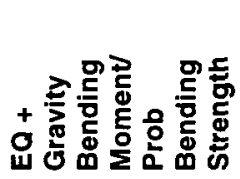 \\
\hline Column, ground & 223 & 67 & 540 & 755 & 2.42 & 11.27 \\
\hline Beam, level 1 & 329 & 595 & 616 & 710 & 1.87 & 1.19 \\
\hline Column, Level 1 & 257 & 349 & 736 & 531 & 2.86 & 1.52 \\
\hline Beam, Level 2 & 246 & 436 & 520 & 521 & 2.11 & 1.19 \\
\hline Column, Level 2 & 300 & 345 & 518 & 548 & 1.73 & 1.59 \\
\hline Beam, roof & 259 & 460 & 145 & 256 & 0.56 & 0.56 \\
\hline
\end{tabular}

Table 5-9-3 Summary of results of longitudinal walls for Bennett Building

\begin{tabular}{|c|c|c|c|c|c|c|}
\hline Member Type & 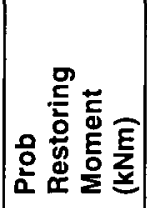 & 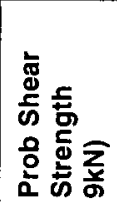 & 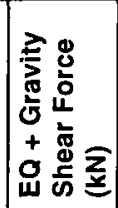 & 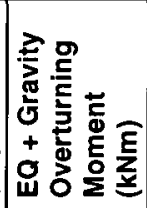 & 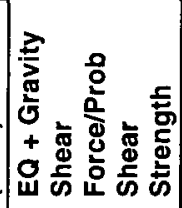 & 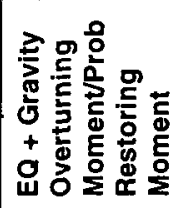 \\
\hline Structural wall, ground-roof & 18600 & 7200 & 2510 & 20100 & 0.35 & 1.08 \\
\hline
\end{tabular}

\section{$\underline{\text { Discussion }}$}

Transverse: Ground floor columns and beams and columns of intermediate floors should have failed through bending. There was little structural damage recorded for this building.

\section{Results Reliability Rating: B}

Longitudinal: The structural walls in this direction should not have failed in shear but should have rocked. There was little structural damage recorded for this building.

\section{Results Reliability Rating: B}




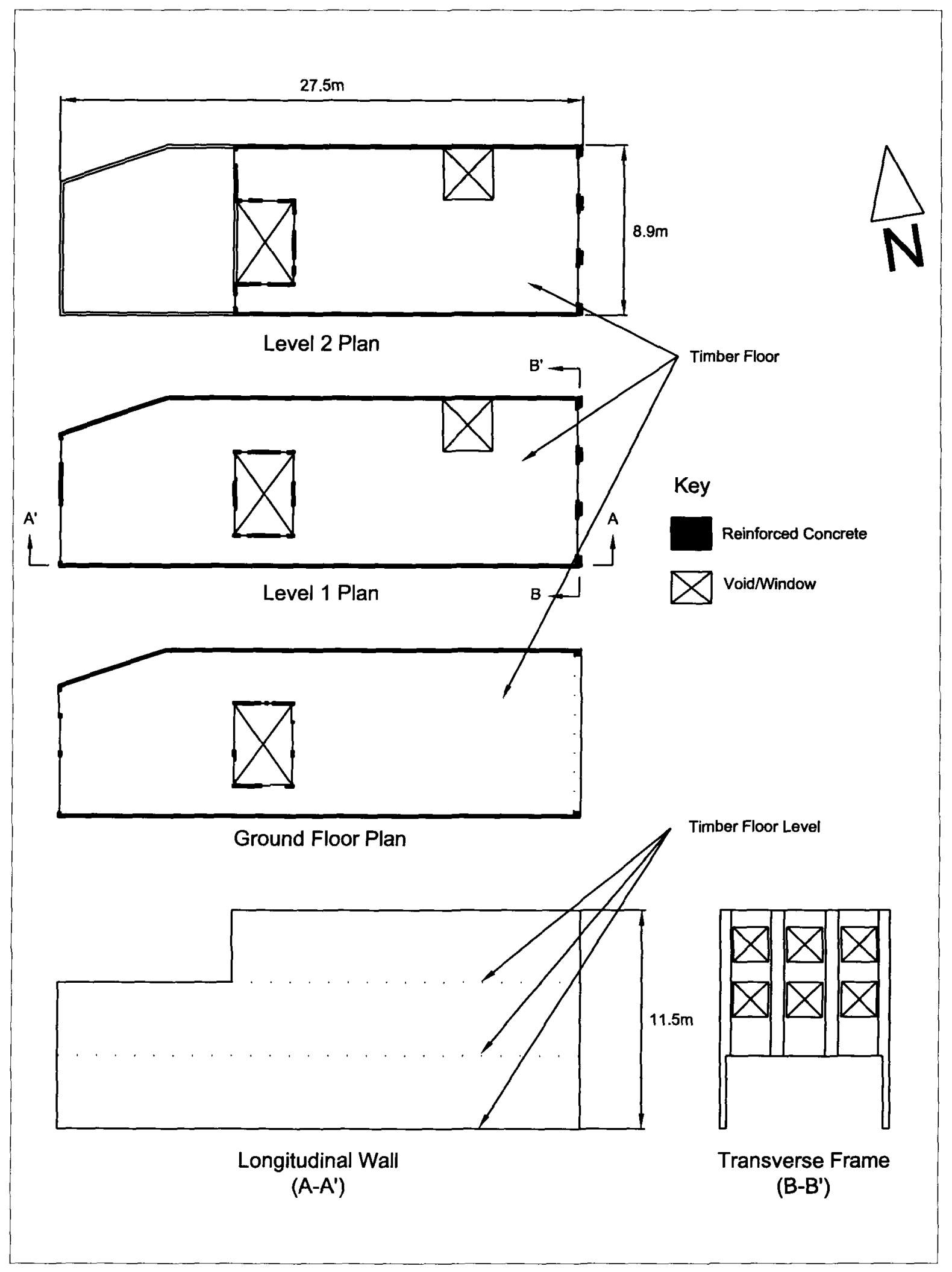

Bennett Building 


\section{Building Description}

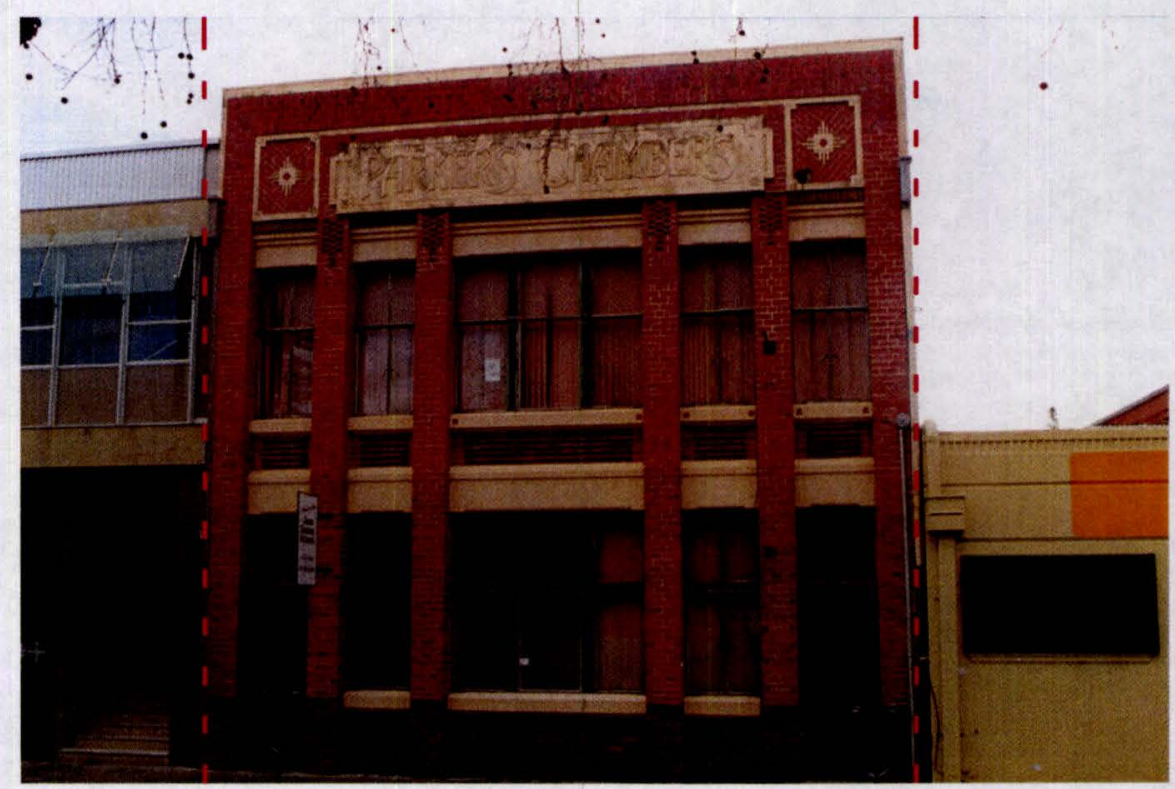

(Herschell Street facade)

Building Name: Parker Chambers

Address: 32 Hastings Street, Napier

Date of Construction: 1929

Primary lateral load resisting structural systems:

Transverse - One reinforced concrete structural wall.

Longitudinal - Two reinforced concrete frames with unreinforced brick masonry infill panels. Construction: Front half of building (Hastings Street end) has timber floors and the back half (Herschell Street end) has reinforced concrete floors. The roof is lightweight timber framed with corrugated steel.

Recorded notes on damage: Structure OK after fire except walls on the $4^{\text {th }}$ floor on Herschell St fell. (Dowrick, 1998); $4^{\text {th }}$ floor walls on Hastings Street facade fell off. Facade down too. (Alexander Turnbull photos \#29461/2, \#F316101/2)

\section{Assumptions made in modelling:}

- The reinforced concrete structural wall resists all the seismic loads in the transverse direction. The strength of the internal brick walls are neglected;

- The fourth floor, primarily two rooftop rooms, is constructed of unreinforced brick masonry and so is only added to the weight of the roof. 


\section{Results}

\section{$\underline{\text { Seismic Loads }}$}

The variables for the seismic load calculation are summarised in the table below.

Table 5-10-1 Summary of Seismic Load Variables for Parker Chambers building (Transverse and Longitudinal)

\begin{tabular}{|l|l|l|l|}
\hline $\boldsymbol{\mu}$ & $\mathbf{C}$ & $\mathbf{W}_{\mathbf{t}}(\mathbf{k N})$ & $\mathbf{V}(\mathbf{k N})$ \\
\hline 1 & 1.56 & 10900 & 17004 \\
\hline
\end{tabular}

\section{$\underline{\text { Results }}$}

Table 5-10-2 Summary of results of transverse wall for Parker Chambers building

\begin{tabular}{|c|c|c|c|c|c|c|}
\hline $\begin{array}{l}\text { Member } \\
\text { Type }\end{array}$ & 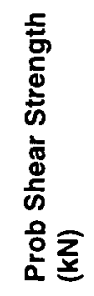 & 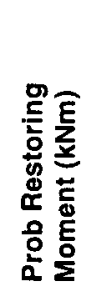 & 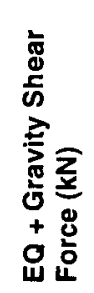 & 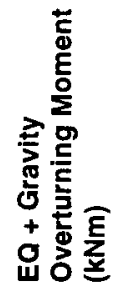 & 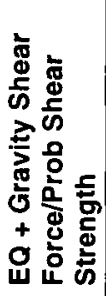 & 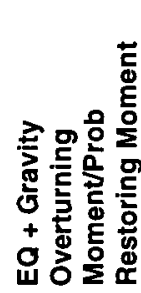 \\
\hline $\begin{array}{l}\text { Structural } \\
\text { wall, } \\
\text { ground- } \\
\text { roof }\end{array}$ & 5850 & 17000 & 16900 & 119000 & 2.89 & 7.00 \\
\hline
\end{tabular}

Table 5-10-3 Summary of results of longitudinal frames for Parker Chambers building

\begin{tabular}{|c|c|c|c|c|c|c|c|c|c|}
\hline \multirow[b]{2}{*}{$\begin{array}{l}\text { Member } \\
\text { Type }\end{array}$} & \multirow[b]{2}{*}{ 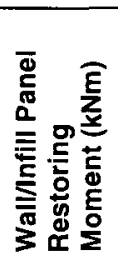 } & \multicolumn{4}{|c|}{ Strength of Infill Panels } & \multirow[b]{2}{*}{ 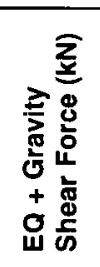 } & \multirow[b]{2}{*}{ 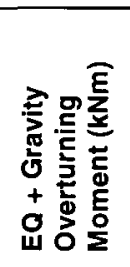 } & \multirow[b]{2}{*}{ 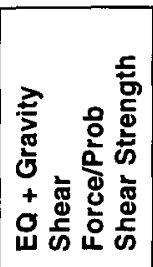 } & \multirow[b]{2}{*}{ 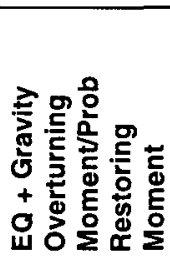 } \\
\hline & & 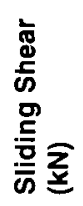 & 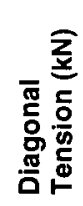 & 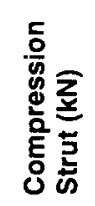 & 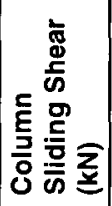 & & & & \\
\hline $\begin{array}{l}\text { Infill wall, } \\
\text { ground- } \\
\text { roof }\end{array}$ & 96400 & 4670 & 5730 & 20800 & 7970 & 10700 & 63600 & 2.29 & 0.66 \\
\hline
\end{tabular}

\section{Discussion}

Transverse: The structural wall should have rocked on its foundations. Though the damage records do not mention this occurring, it may have occurred without observation.

\section{Results Reliability Rating: C}

Longitudinal: The infill panels in the frames in his direction should have suffered sliding shear failure. The damage records do not mention their failure.

\section{Results Reliability Rating: C}




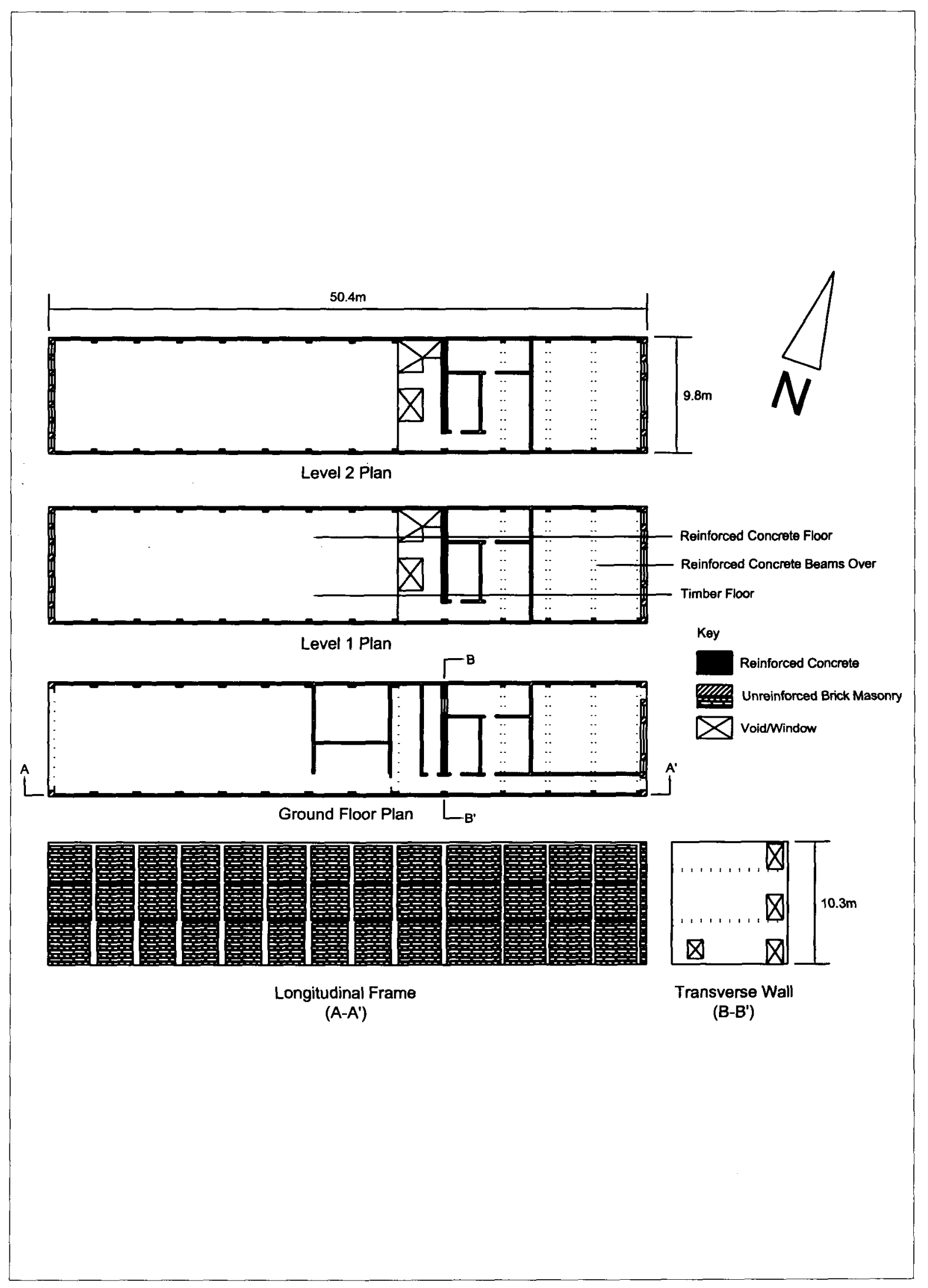

Parker Chambers 


\section{Building Description}

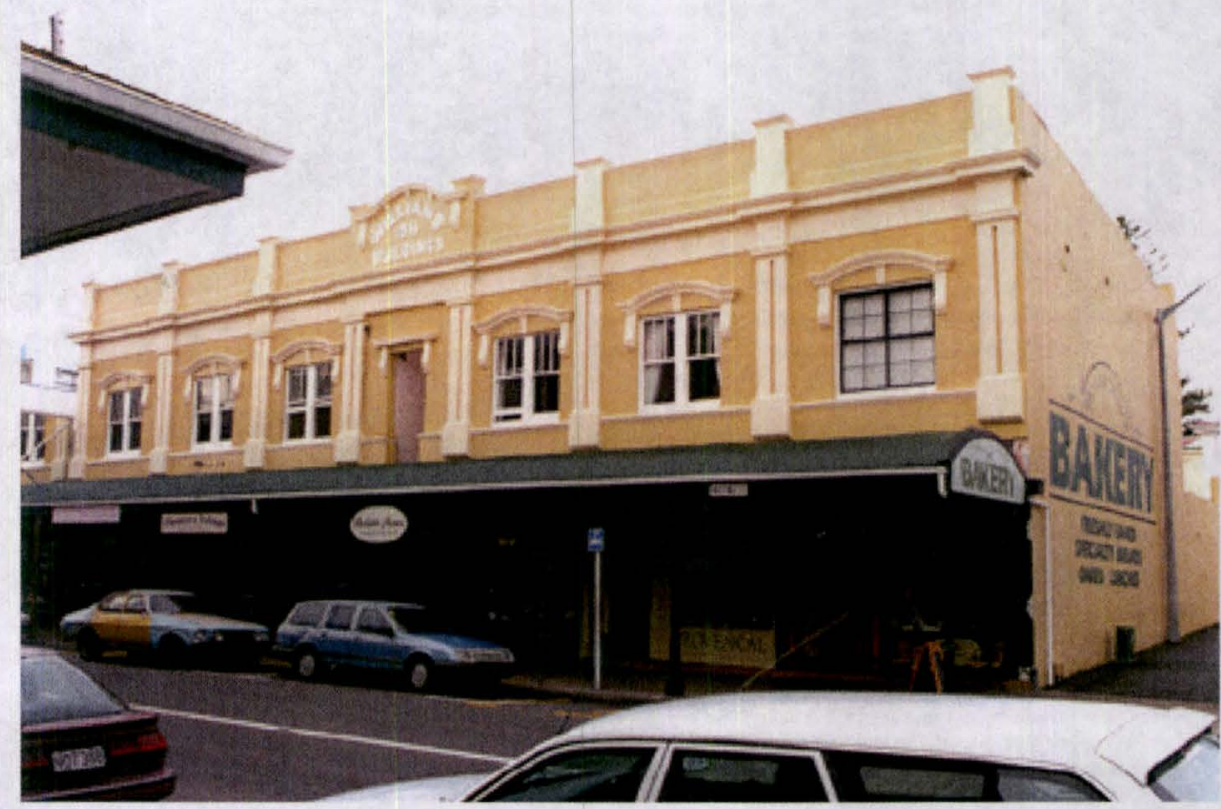

Building Name: Williams Buildings (I)

Address: 100-110 Hastings Street, Napier

Date of Construction: 1911

\section{Primary lateral load resisting structural systems:}

Transverse - Eight reinforced concrete structural walls.

Longitudinal - Two reinforced concrete moment resisting frames.

Construction: Timber intermediate floor and lightweight timber framed roof clad in corrugated steel. Reinforced concrete walls on all facades. Facade to street at ground floor is glazed.

Recorded notes on damage: "Slight" (Dowrick, 1998).

Assumptions made in modelling:

- The rear portion of the building is of reinforced concrete walls and lightweight timber framed roof. It is not modelled as the weak diaphragm cannot transfer the seismic loads;

- The two moment resisting frames on the street (West) are connected rigidly at roof level. The passageway that runs down the middle of the building separates them. The East (rear) facade is similar;

- The columns for the moment resisting frames on the street facade are assumed to be $1.33 \mathrm{~m}$ length of each structural wall in the perpendicular direction. 


\section{Results}

\section{Seismic Loads}

The variables for the seismic load calculation are summarised in the table below.

Table 5-11-1 Summary of Seismic Load Variables for Williams Buildings (I) building (Transverse and Longitudinal)

\begin{tabular}{|l|l|l|l|}
\hline $\boldsymbol{\mu}$ & $\mathbf{C}$ & $\mathbf{W}_{\mathbf{t}}(\mathbf{k N})$ & $\mathbf{V}(\mathbf{k N})$ \\
\hline 1 & 1.56 & 10900 & 17004 \\
\hline
\end{tabular}

\section{Results}

Table 5-11-2 Summary of results of transverse walls for Williams Buildings (I) building

\begin{tabular}{|c|c|c|c|c|c|c|}
\hline Member Type & 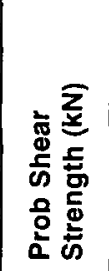 & 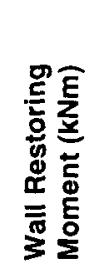 & 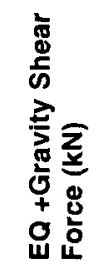 & 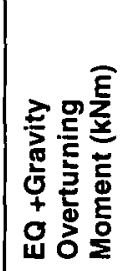 & 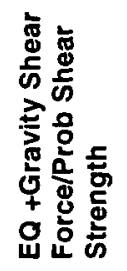 & 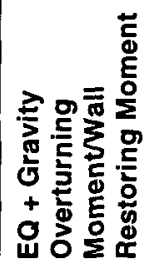 \\
\hline Structural wall, ground-level 1 & 6385 & 2662 & 2210 & 17600 & 0.35 & $\overline{6.61}$ \\
\hline
\end{tabular}

Table 5-11-3 Summary of results of longitudinal frame for Williams Buildings (I) building

\begin{tabular}{|c|c|c|c|c|c|c|}
\hline Member Type & 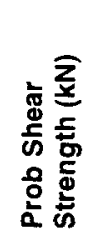 & 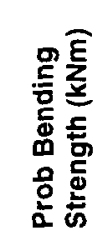 & 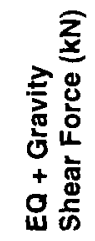 & 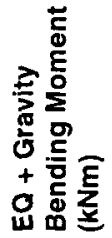 & 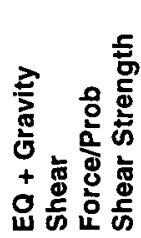 & 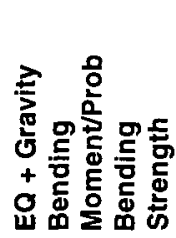 \\
\hline Column, ground & 130 & 471 & 1110 & 1960 & 8.54 & 4.16 \\
\hline Beam, level 1 & 340 & 348 & 855 & 798 & 2.51 & 2.29 \\
\hline Column, level 1 & 225 & 471 & 1110 & 1080 & 4.93 & 2.29 \\
\hline Beam, roof & 680 & 310 & 785 & 984 & 1.15 & 3.17 \\
\hline
\end{tabular}

\section{Discussion}

Transverse: The results indicate that the reinforced concrete walls may have rocked on their foundations. Though records suggest little structural damage, the walls may have rocked without observation.

\section{Results Reliability Rating: $\mathrm{C}$}

Longitudinal: The results suggest that the ground floor columns, the beams and columns at level 1 should have failed in shear. Again the records suggest there was little structural damage.

\section{Results Reliability Rating: C}




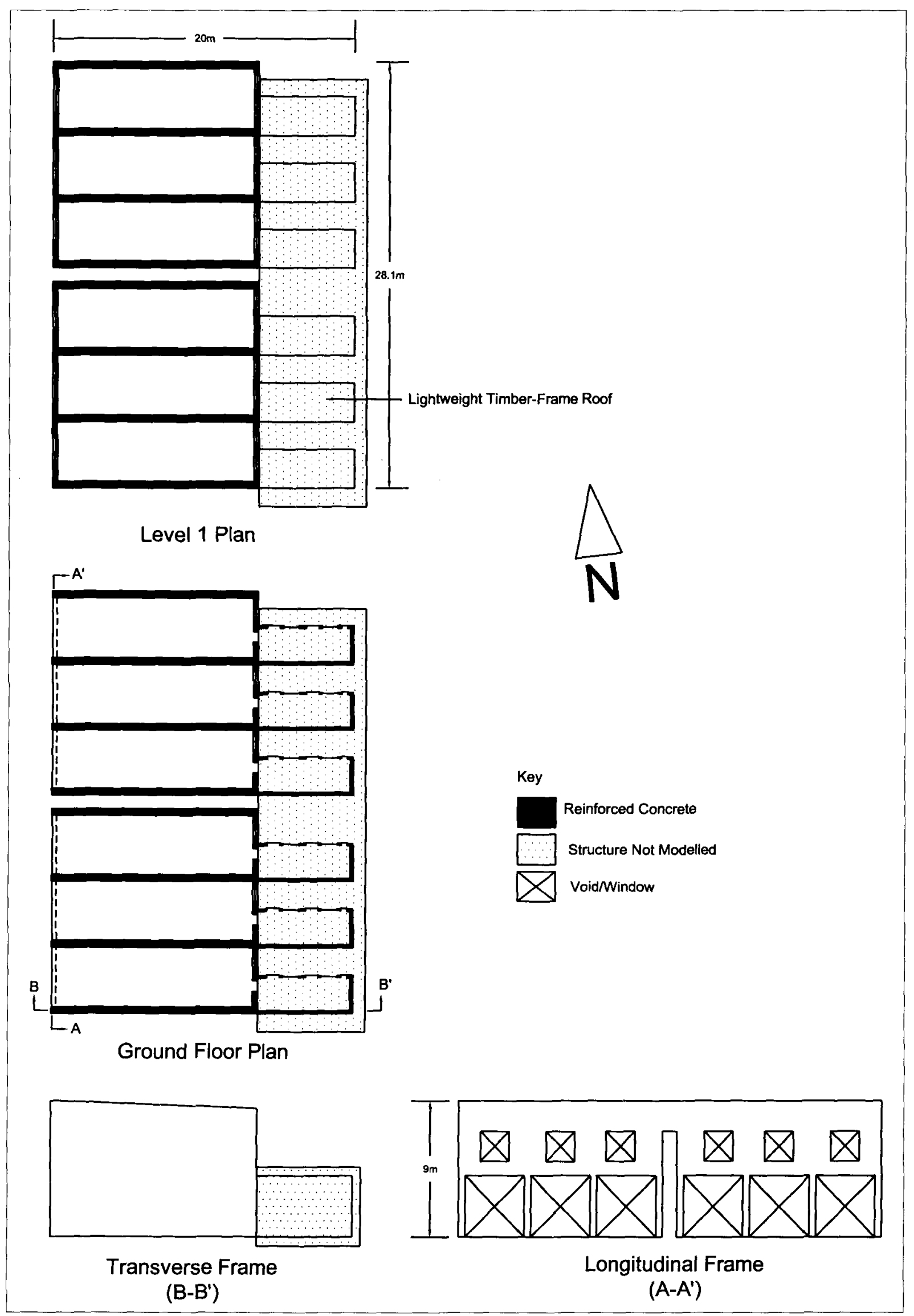

Williams Buildings (I) 


\section{Building Description}

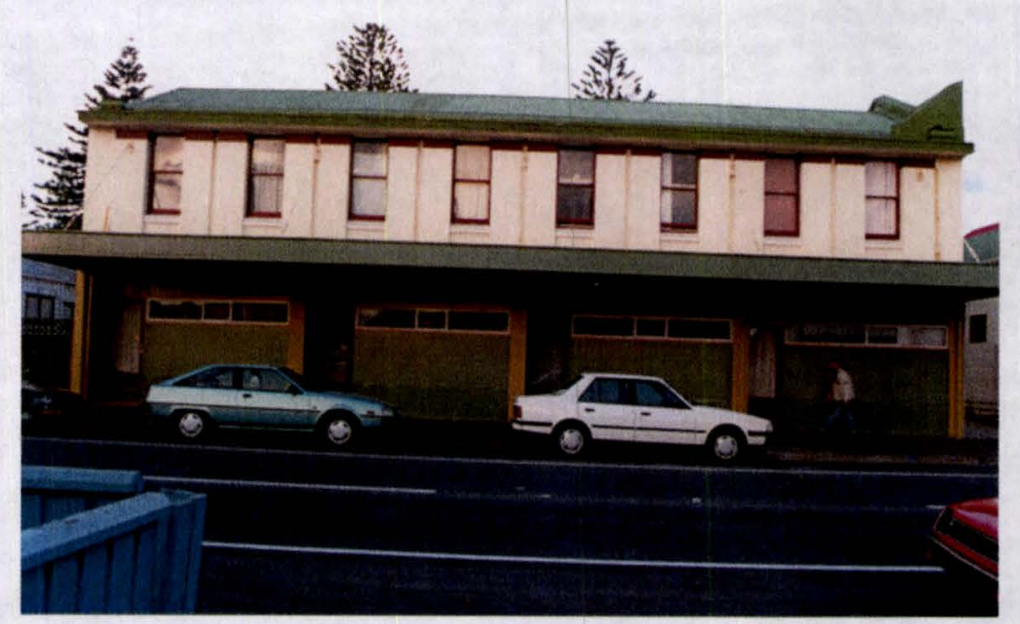

Building Name: Williams Buildings (II)

Address: 236-238 Hastings Street, Napier

Date of Construction: $\mathrm{c} 1928$

Primary lateral load resisting structural systems:

Transverse - Five reinforced concrete moment resisting frames with unreinforced brick masonry infill panels.

Longitudinal - Two reinforced concrete moment resisting frames with unreinforced brick masonry infill panels.

Construction: Light timber floor and timber framed corrugated steel roof.

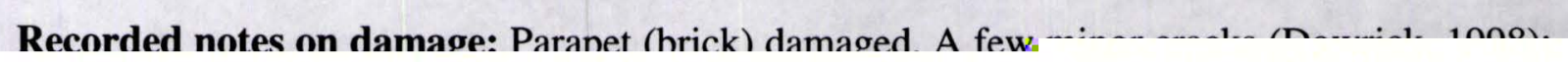




\section{Results}

\section{$\underline{\text { Seismic Loads }}$}

The variables for the seismic load calculation are summarised in the table below.

Table 5-12-1 Summary of Seismic Load Variables for Williams Buildings (II) building (Transverse and Longitudinal)

\begin{tabular}{|l|l|l|l|}
\hline $\boldsymbol{\mu}$ & $\mathbf{C}$ & $\mathbf{W}_{\mathbf{t}}(\mathbf{k N})$ & $\mathbf{V}(\mathbf{k N})$ \\
\hline 1 & 1.56 & 2773 & 4326 \\
\hline
\end{tabular}

\section{$\underline{\text { Results }}$}

Table 5-12-2 Summary of results of transverse frame for Williams Buildings (II) building

\begin{tabular}{|c|c|c|c|c|c|c|c|c|c|}
\hline \multirow[b]{2}{*}{$\begin{array}{l}\text { Member } \\
\text { Type }\end{array}$} & \multirow[b]{2}{*}{ 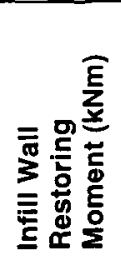 } & \multicolumn{4}{|c|}{ Strength of Infill Panels } & \multirow[b]{2}{*}{ 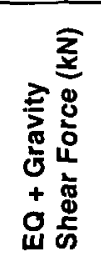 } & \multirow[b]{2}{*}{ 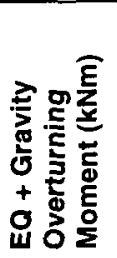 } & \multirow[b]{2}{*}{ 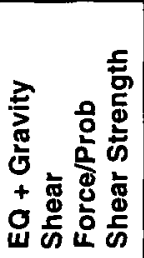 } & \multirow[b]{2}{*}{ 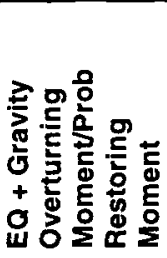 } \\
\hline & & 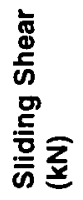 & 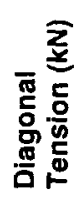 & 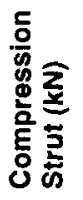 & 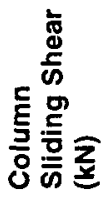 & & & & \\
\hline $\begin{array}{l}\text { Infill wall, } \\
\text { ground }\end{array}$ & 3787 & 778 & 1059 & 3819 & 1016 & $\overline{920}$ & 11100 & 1.18 & 2.93 \\
\hline
\end{tabular}

Table 5-12-3 Summary of results of longitudinal frame for Williams Buildings (II) building

\begin{tabular}{|c|c|c|c|c|c|c|}
\hline Member Type & 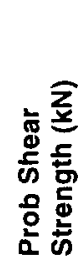 & 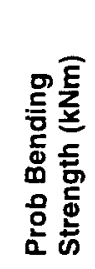 & 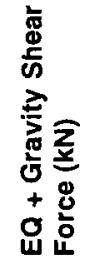 & 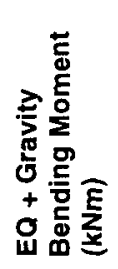 & 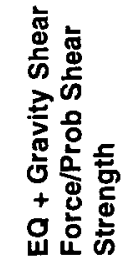 & 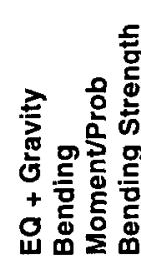 \\
\hline Column, ground & 165 & 127 & 503 & 832 & 3.05 & 6.55 \\
\hline Beam, level 1 & 119 & 125 & 474 & 620 & 3.98 & 4.96 \\
\hline Column, level 1 & 149 & 127 & 315 & 490 & 2.11 & 3.86 \\
\hline Beam, roof & 119 & 125 & 208 & 280 & 1.75 & 2.24 \\
\hline
\end{tabular}

\section{Discussion}

Transverse: The analysis results suggest the infill wall should have rocked on its foundations. The infill panels should have failed in sliding shear action. The structure apparently suffered little structural damage.

\section{Results Reliability Rating: C}

Longitudinal: All members in these frames should have suffered cracking due to yielding of reinforcement steel. The structure apparently suffered little structural damage.

\section{Results Reliability Rating: C}



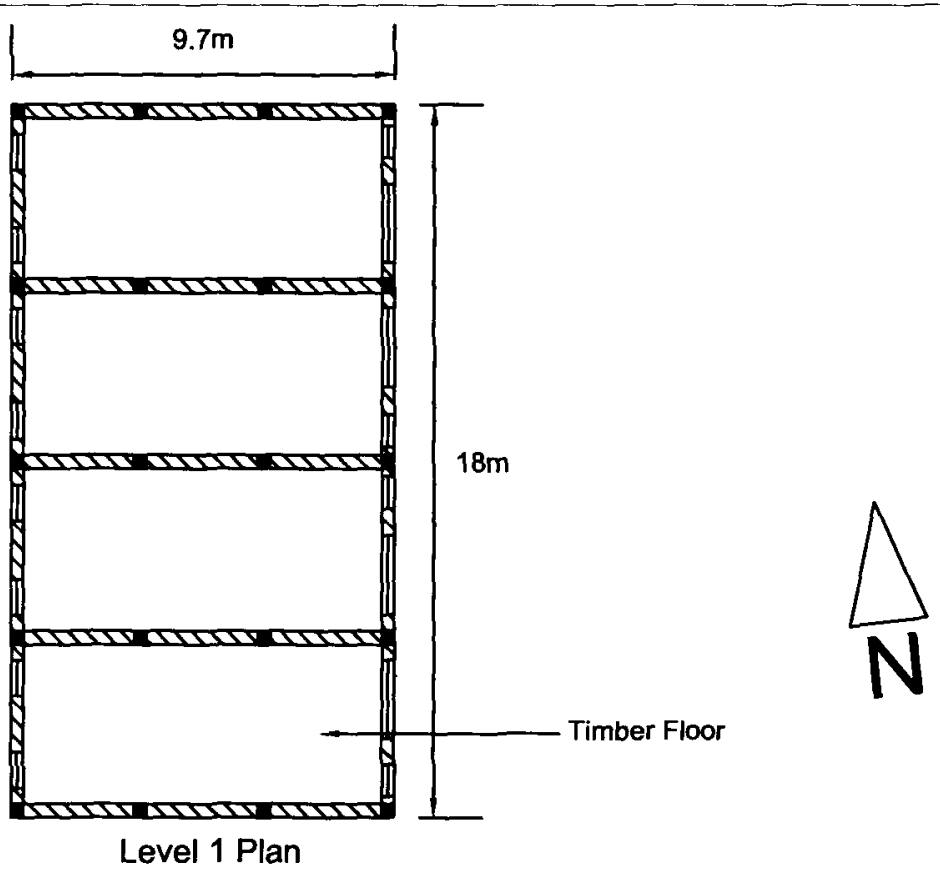

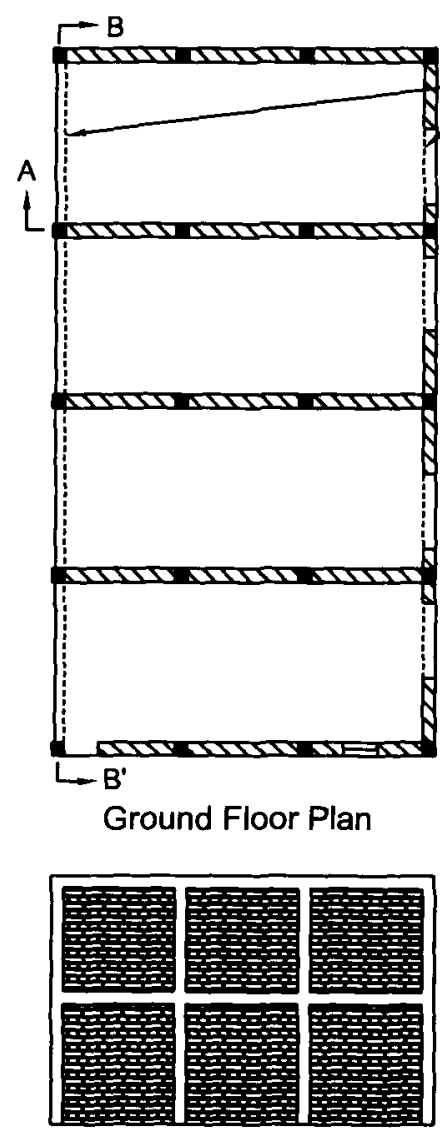

Transverse Frame (A-A')
Reinforced Concrete Beams Over

Key

Reinforced Concrete

272 Unreinforced Brick Masonry

$\searrow$ void/Window

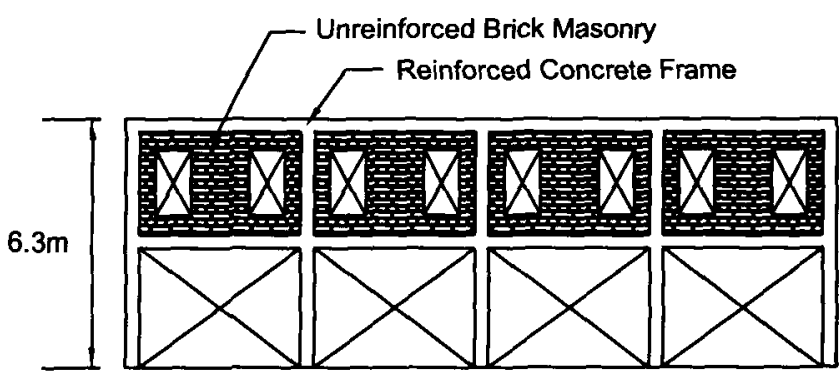

Longitudinal Frame (B-B') 


\section{Building Description}

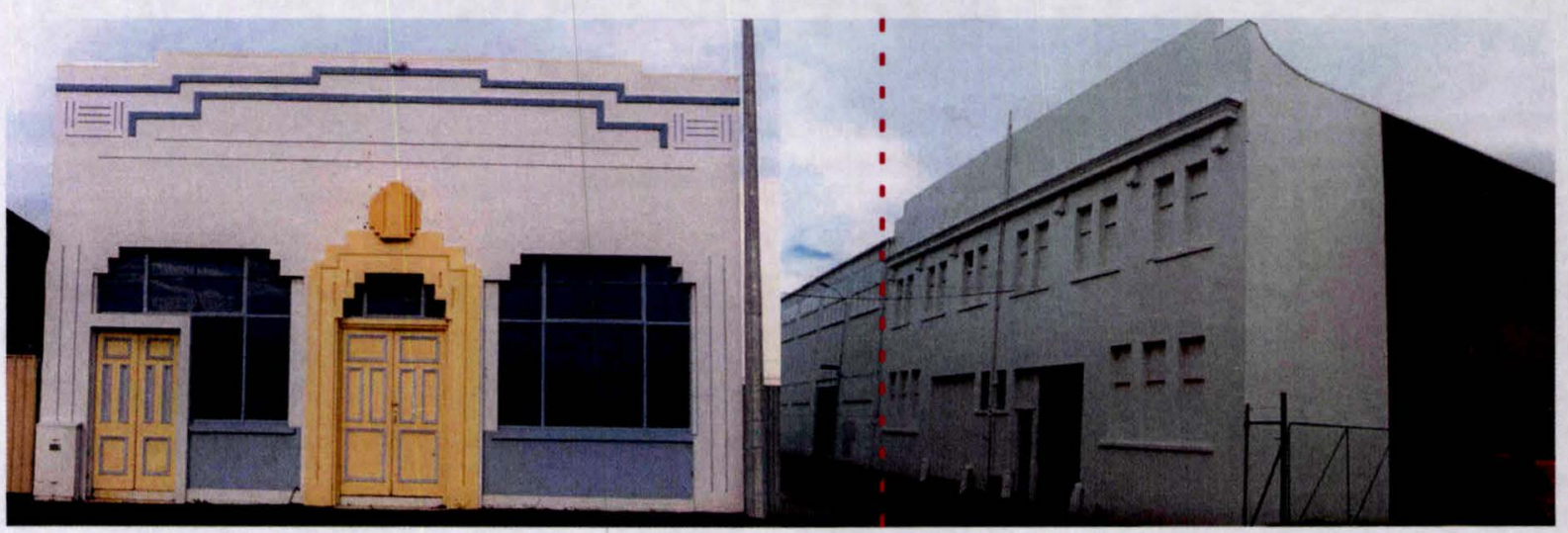

(Left) Bridge Street facade; (Right) Mahia Street facade

Building Name: Richardson \& Co.

Address: 21 Bridge Street, Port Ahuriri, Napier

Date of Construction: c1930

\section{Primary lateral load resisting structural systems:}

Transverse - One reinforced concrete structural wall and one reinforced concrete moment resisting frame.

Longitudinal - Two reinforced concrete structural walls.

Construction: Timber floor and lightweight timber with corrugated steel roof. Steel universal columns support the first floor. Steel universal beams and columns support the roof trusses.

Recorded notes on damage: 1-storey part is badly cracked, 2-storey part is slightly damaged; badly wrenched; Floor wrecked; Walls cracked (Dowrick, 1998). Diagonal crack from bottom left corner of window to doorway. Hairline cracks on other side of window. Crack on left-side wall from top of parapet down. (Alexander Turnbull Library photos \#P5, \#P10.)

\section{Assumptions made in modelling:}

- The foundations are assumed to be of similar proportions as for Gilberd \& Co. building;

- The lightweight timber diaphragms do not transfer seismic sufficiently between vertical the structural elements. Therefore, the seismic load is divided equally between the structural walls in the longitudinal direction and structural wall and moment resisting frame in the transverse direction;

- The single storey URM brick section of the building (Bridge Street facade) is not analysed. 


\section{Results}

Seismic Loads

The variables for the seismic load calculation are summarised in the table below.

Table 5-13-1 Summary of Seismic Load Variables for Richardson \& Co. building (Transverse and Longitudinal)

\begin{tabular}{|l|l|l|l|}
\hline$\mu$ & $\mathbf{C}$ & $\mathbf{W}_{\mathbf{t}}(\mathbf{k N})$ & $\mathbf{V}(\mathbf{k N})$ \\
\hline 1 & 1.14 & 7100 & 8094 \\
\hline
\end{tabular}

\section{$\underline{\text { Results }}$}

Table 5-13-2 Summary of results of transverse wall and frame for Richardson \& Co. building

\begin{tabular}{|c|c|c|c|c|c|c|c|c|c|}
\hline Member Type & 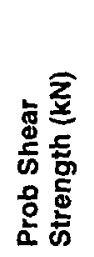 & 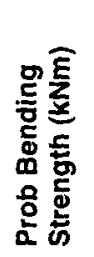 & 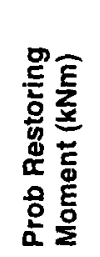 & 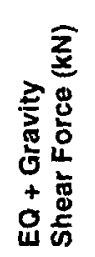 & 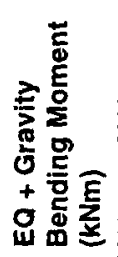 & 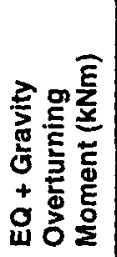 & 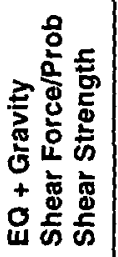 & 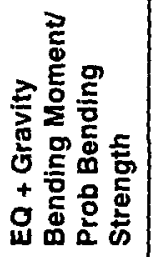 & 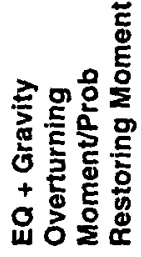 \\
\hline Structural wall, ground-roof & 5400 & & 11200 & 3900 & & 25400 & 0.72 & & 2.27 \\
\hline Column, ground & 699 & 741 & & 1450 & 2470 & & 2.07 & 3.33 & \\
\hline Beam, level 1 & 735 & 1020 & & 689 & 980 & & 0.94 & 0.96 & \\
\hline Column, level 1 & 483 & 563 & & 566 & 600 & & 1.17 & 1.07 & \\
\hline Beam, roof & 842 & 1180 & & 530 & 683 & & 0.63 & 0.58 & \\
\hline
\end{tabular}

Table 5-13-3 Summary of results of longitudinal walls for Richardson \& Co. building

\begin{tabular}{|c|c|c|c|c|c|c|}
\hline Member Type & 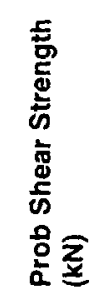 & 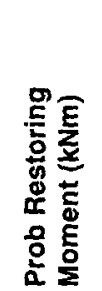 & 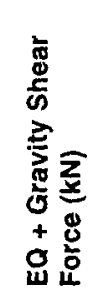 & 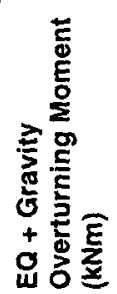 & 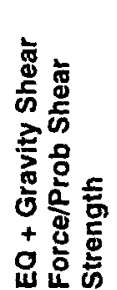 & 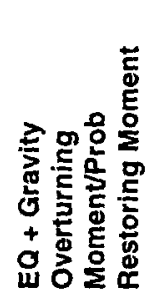 \\
\hline Structural wall, ground-roof & 7840 & 16900 & 3910 & 25400 & 0.50 & 1.50 \\
\hline
\end{tabular}

\section{Discussion}

Transverse: The structural wall in this direction should have rocked on its foundations. The damage records suggest this wall suffered no structural damage but the wall may have rocked without observation. Reinforcing in the columns at ground floor should have yielded.

\section{Results Reliability Rating: C}

Longitudinal: The structural walls in this direction should not have suffered any damage but should have rocked on its foundations.

\section{Results Reliability Rating: C}




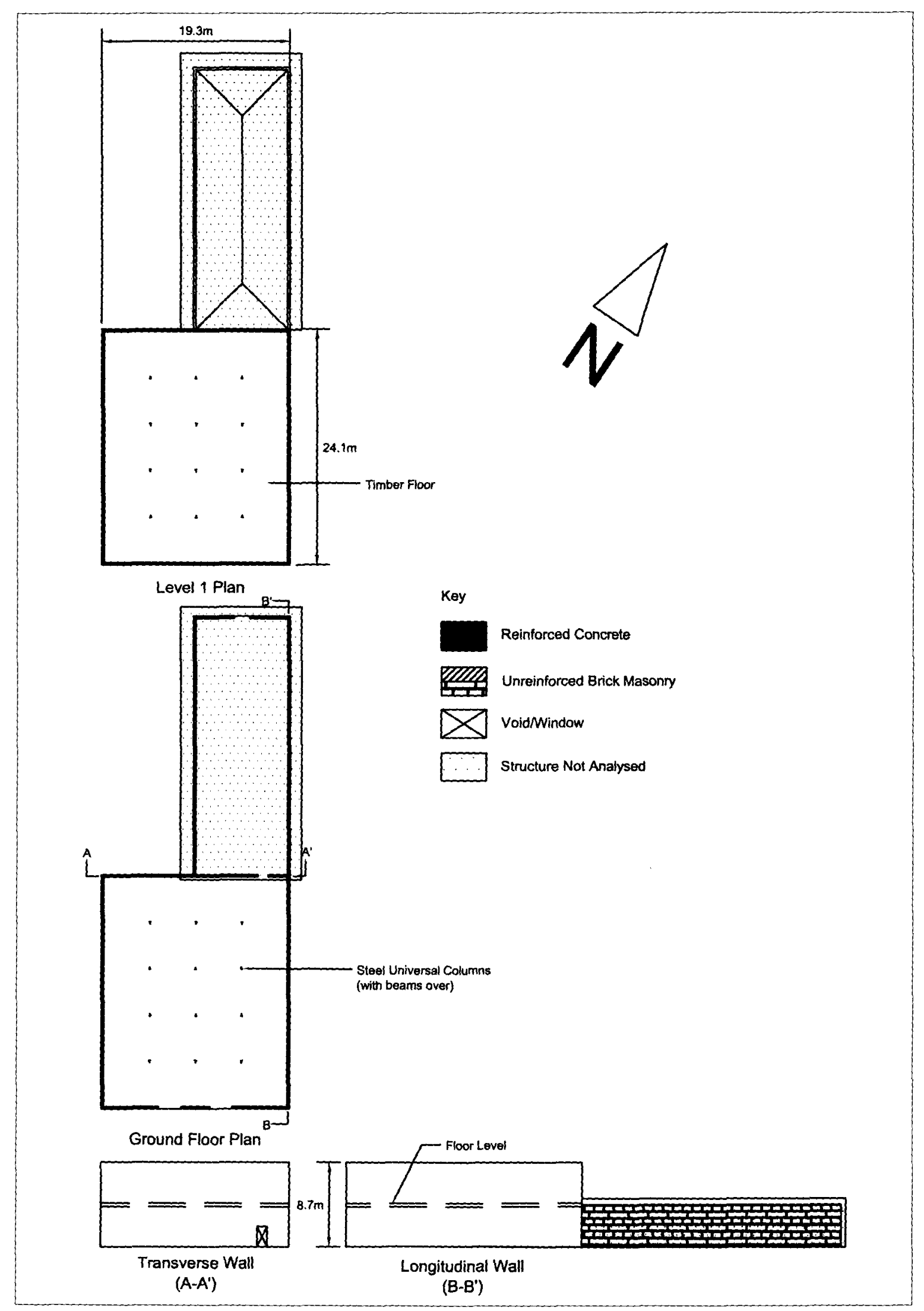

Richardson \& Co. Ltd 


\section{Building Description}

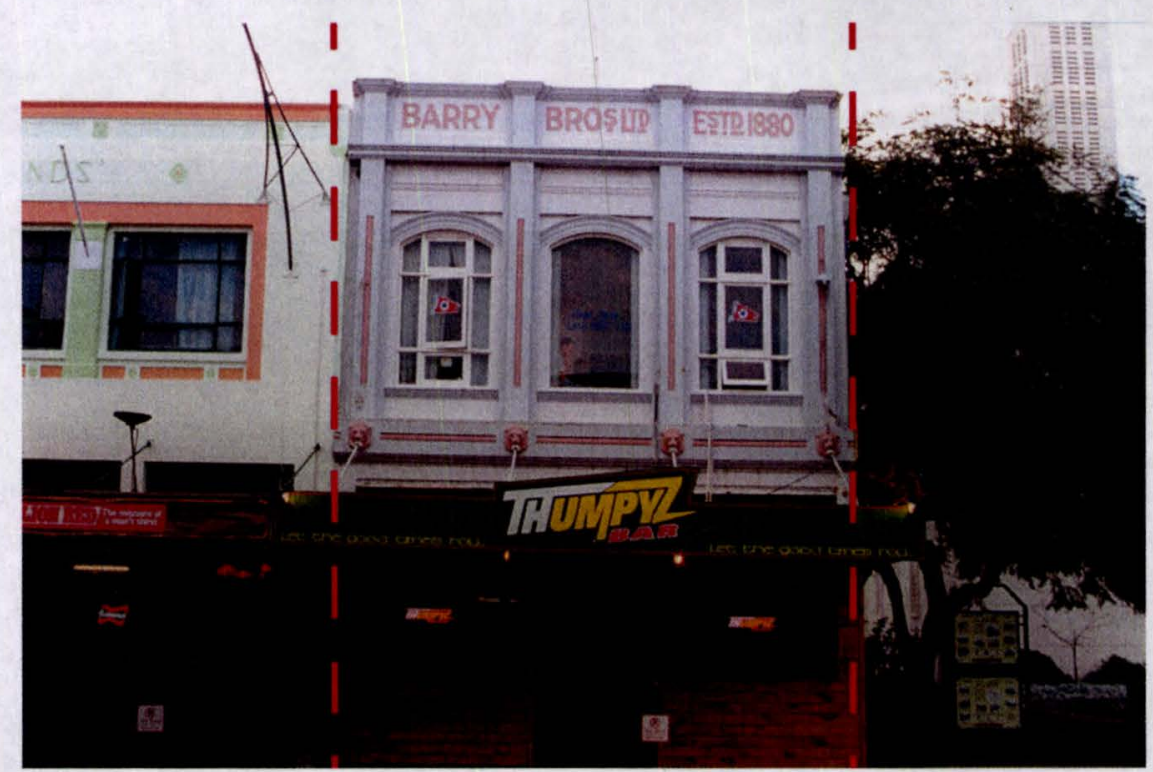

Building Name: Howe Bros.

Address: 7 Hastings Street, Napier

\section{Date of Construction: 1911}

\section{Primary lateral load resisting structural systems:}

Transverse - Eight reinforced concrete moment resisting frames to Level 1 only. Reinforced concrete columns at Level 1 are tied by reinforced concrete beams in longitudinal direction only.

Longitudinal - Two reinforced concrete moment resisting frames to roof level, with unreinforced brick masonry infill panels. The north frame has many penetrations in the infill panels.

Construction: Reinforced concrete first floor and a lightweight timber framed corrugated steel roof. Reinforced concrete stairs.

Recorded notes on damage: Tile roof and two large chimneys down, plaster and brickwork stripped off sidewalls. (Alexander Turnbull Library photo \#29461/2)

\section{Assumptions made in modelling:}

- Only the transverse frame with the highest gravity load is modelled. Each frame is assumed to resist an equal fraction of the total seismic force in this direction. The columns at level 1 are modelled and tied together by a pin-jointed timber member, representing the roof truss that spans between;

- The longitudinal frame with solid infill panels is assumed to resist $90 \%$ of the seismic load, with the heavily penetrated northern infill wall resisting the remainder as the former is significantly stiffer (due to the presence of infill panels). 


\section{Results}

\section{Seismic Loads}

The variables for the seismic load calculation are summarised in the table below.

Table 5-14-1 Summary of Seismic Load Variables for Howe Bros. building (Transverse and Longitudinal)

\begin{tabular}{|l|l|l|l|}
\hline $\boldsymbol{\mu}$ & $\mathbf{C}$ & $\mathbf{W}_{\mathbf{t}}(\mathbf{k N})$ & $\mathbf{V}(\mathbf{k N})$ \\
\hline 1 & 1.56 & 3839 & 5989 \\
\hline
\end{tabular}

\section{Results}

Table 5-14-2 Summary of results of transverse frames for Howe Bros. building

\begin{tabular}{|c|c|c|c|c|c|c|}
\hline $\begin{array}{l}\text { Member } \\
\text { Type }\end{array}$ & 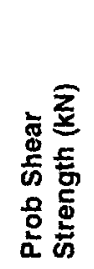 & 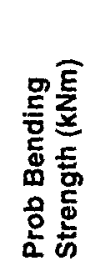 & 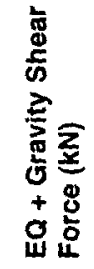 & 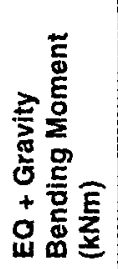 & 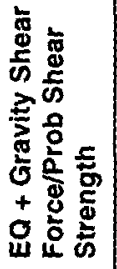 & 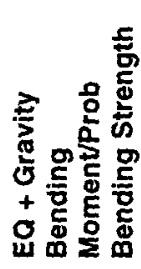 \\
\hline $\begin{array}{l}\text { Column, } \\
\text { ground }\end{array}$ & 228 & 205 & 407 & 1060 & 1.79 & 5.17 \\
\hline $\begin{array}{l}\text { Beam, } \\
\text { level } 1\end{array}$ & 154 & 176 & 455 & 1380 & 2.95 & 7.84 \\
\hline $\begin{array}{l}\text { Column, } \\
\text { level } 1\end{array}$ & 227 & 205 & 201 & 806 & 0.89 & 3.93 \\
\hline
\end{tabular}

Table 5-14-3 Summary of results of longitudinal infill wall for Howe Bros. building

\begin{tabular}{|c|c|c|c|c|c|c|c|c|c|}
\hline \multirow[b]{2}{*}{$\begin{array}{l}\text { Member } \\
\text { Type }\end{array}$} & \multirow[b]{2}{*}{ 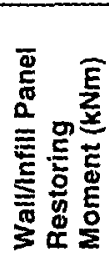 } & \multicolumn{4}{|c|}{ Strength of Infill Panels } & \multirow[b]{2}{*}{ 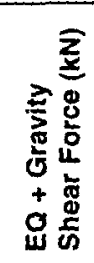 } & \multirow[b]{2}{*}{ 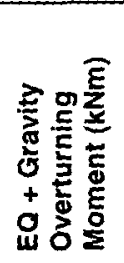 } & \multirow[b]{2}{*}{ 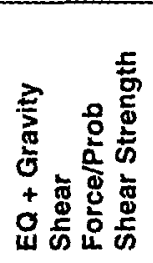 } & \multirow[b]{2}{*}{ 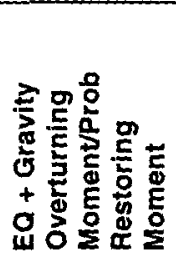 } \\
\hline & & 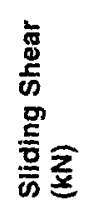 & 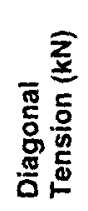 & 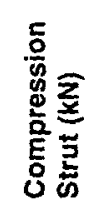 & 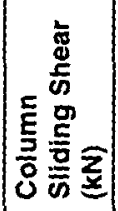 & & & & \\
\hline $\begin{array}{l}\text { Infill wall, } \\
\text { ground-roof }\end{array}$ & 18900 & 3350 & 3470 & 17400 & 4740 & 5490 & 32000 & 1.64 & 1.69 \\
\hline
\end{tabular}

\section{Discussion}

Transverse: All members of the frames in this direction should have experienced concrete cracking due to yielding of the reinforcing steel. The damage records do not mention this type of damage.

\section{Results Reliability Rating: C}

Longitudinal: The wall infill panels should have failed in sliding shear action and rocked on its foundations. No damage is noted.

\section{Results Reliability Rating: C}




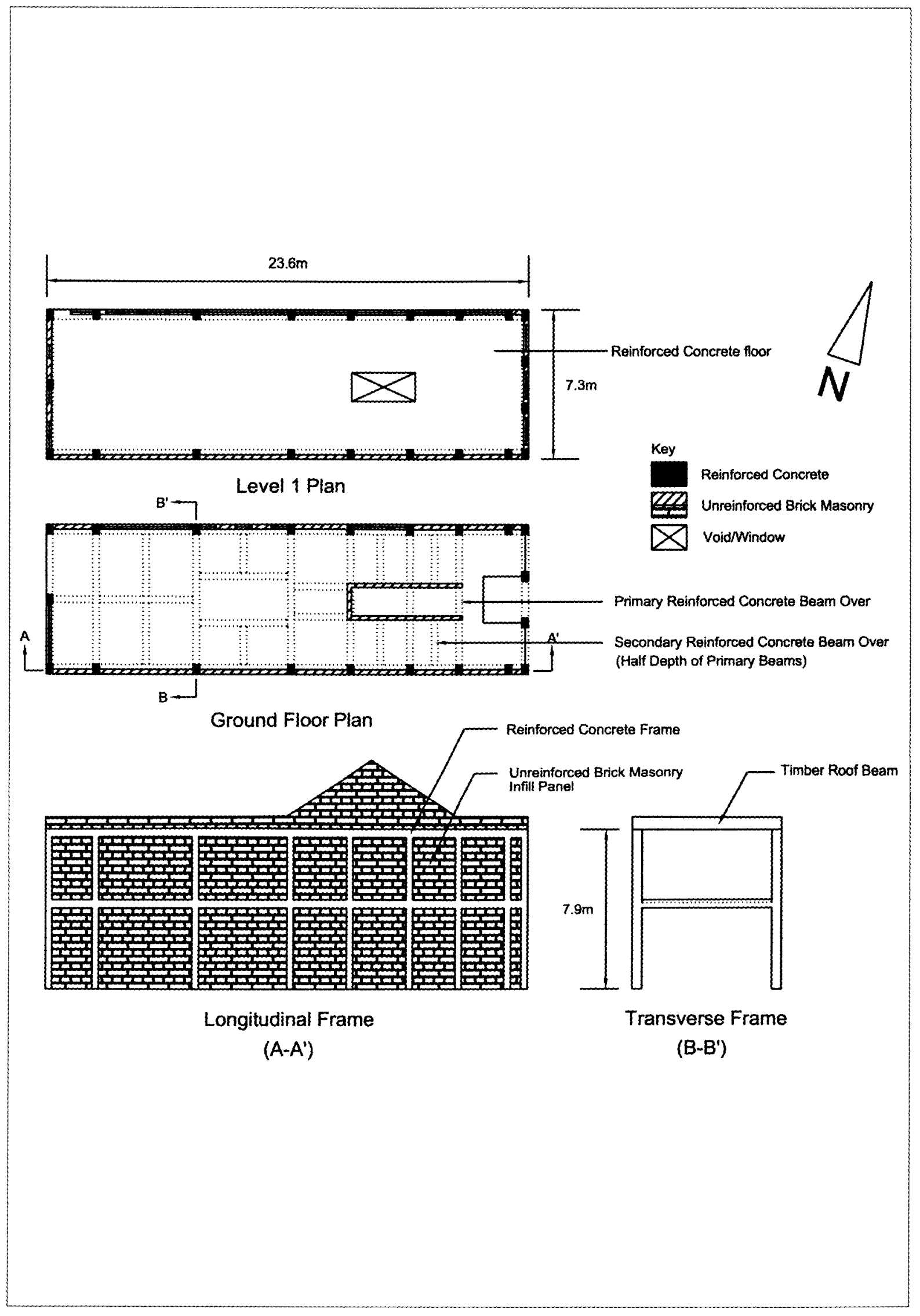

\section{Howe Bros}




\section{Building Description}

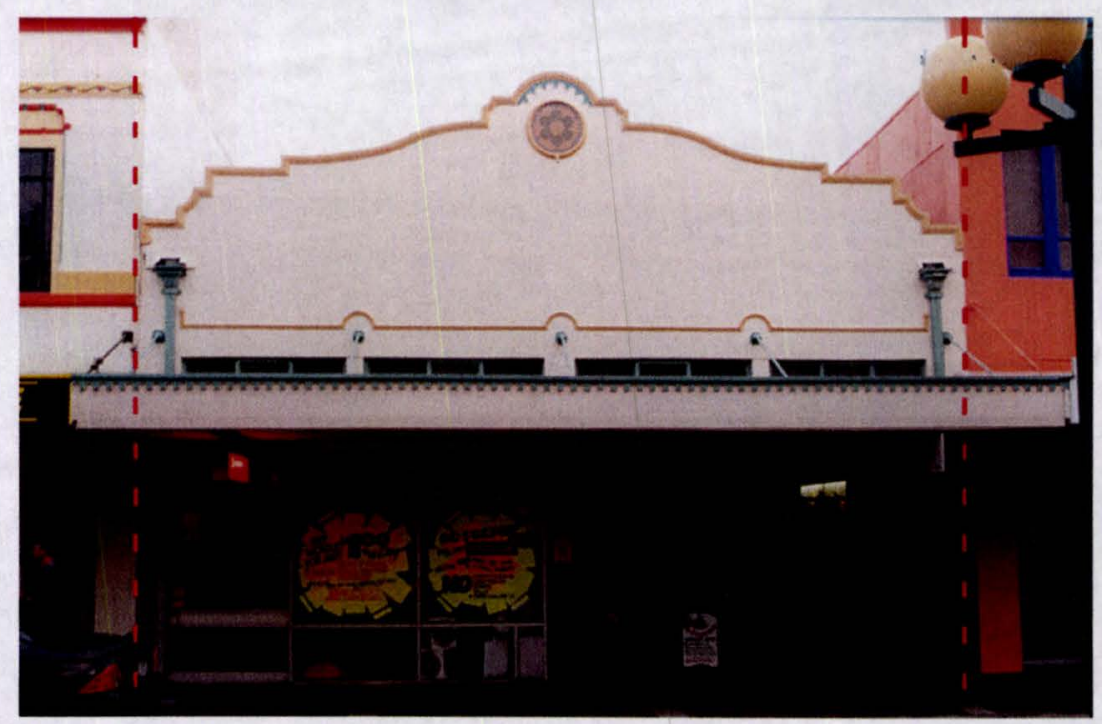

Building Name: West (JS) \& Co.

Address: 84 Emerson Street, Napier

Date of Construction: 1930

Primary lateral load resisting structural systems:

Transverse - Two reinforced concrete moment resisting frames.

Longitudinal - Two reinforced concrete structural walls with reinforced concrete pilasters.

Construction: Lightweight timber floor and lightweight timber framed with corrugated steel roof.

Recorded notes on damage: Timber floor burnt out. (Alexander Turnbull Library photo \#EP689) Sidewalls damaged at first floor. (Specifications for reconditioning, 1931)

\section{Assumptions made in modelling:}

- As the construction details of Level 1 are not known, the North facade is assumed to have the Bennett Building details. The building length is assumed to extend to the wall adjoining the light well that separated the building from the building adjoining the south facade;

- Construction details are taken from the specifications mentioned in the damage records and from the Bennett Building. 
Seismic Loads

The variables for the seismic load calculation are summarised in the table below.

Table 5-15-1 Summary of Seismic Load Variables for West \& Co. building (Transverse and Longitudinal)

\begin{tabular}{|l|l|l|l|}
\hline $\boldsymbol{\mu}$ & $\mathbf{C}$ & $\mathbf{W}_{\mathbf{t}}(\mathbf{k N})$ & $\mathbf{V}(\mathbf{k N})$ \\
\hline 1 & 1.56 & 2370 & 3697 \\
\hline
\end{tabular}

\section{Results}

Table 5-15-2 Summary of results of transverse frame for West \& Co. building

\begin{tabular}{|c|c|c|c|c|c|c|}
\hline $\begin{array}{l}\text { Member } \\
\text { Type }\end{array}$ & 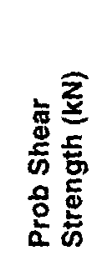 & 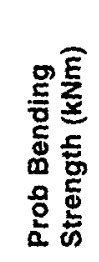 & 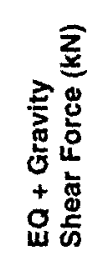 & 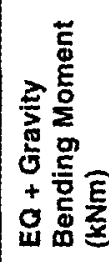 & 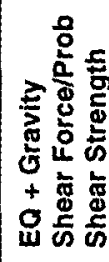 & 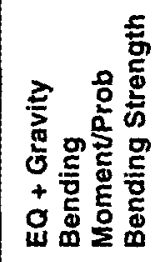 \\
\hline $\begin{array}{l}\text { Column, } \\
\text { ground }\end{array}$ & 187 & 127 & 610 & 1030 & 3.26 & 8.11 \\
\hline $\begin{array}{l}\text { Beam, } \\
\text { level } 1\end{array}$ & 407 & 487 & 682 & 1080 & 1.68 & 2.22 \\
\hline $\begin{array}{l}\text { Column, } \\
\text { level } 1\end{array}$ & 343 & 140 & 545 & 643 & 1.59 & 4.59 \\
\hline Beam, roof & 387 & 463 & 337 & 451 & 0.87 & 0.97 \\
\hline
\end{tabular}

Table 5-15-3 Summary of results of longitudinal wall for West \& Co. building

\begin{tabular}{|c|c|c|c|c|c|c|}
\hline $\begin{array}{l}\text { Member } \\
\text { Type }\end{array}$ & 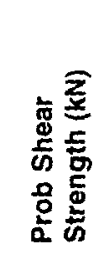 & 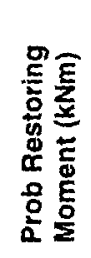 & 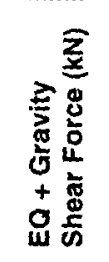 & 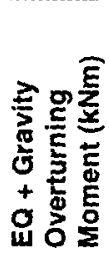 & 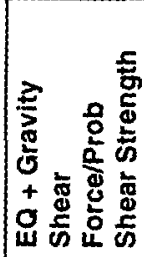 & 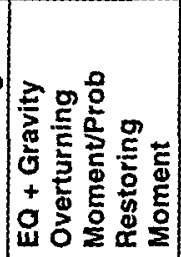 \\
\hline $\begin{array}{l}\text { Structural } \\
\text { wall, } \\
\text { ground-roof }\end{array}$ & 5600 & 11500 & 1850 & 10600 & 0.33 & 0.92 \\
\hline
\end{tabular}

\section{Discussion}

Transverse: The columns in this direction should have failed in bending and then shear. The beams at Level 1 should have failed in shear. Records do not mention this damage.

\section{Results Reliability Rating: C}

Longitudinal: The results indicate that the structural walls in this direction should not have failed in either shear or rocked on their foundations.

Results Reliability Rating: C 


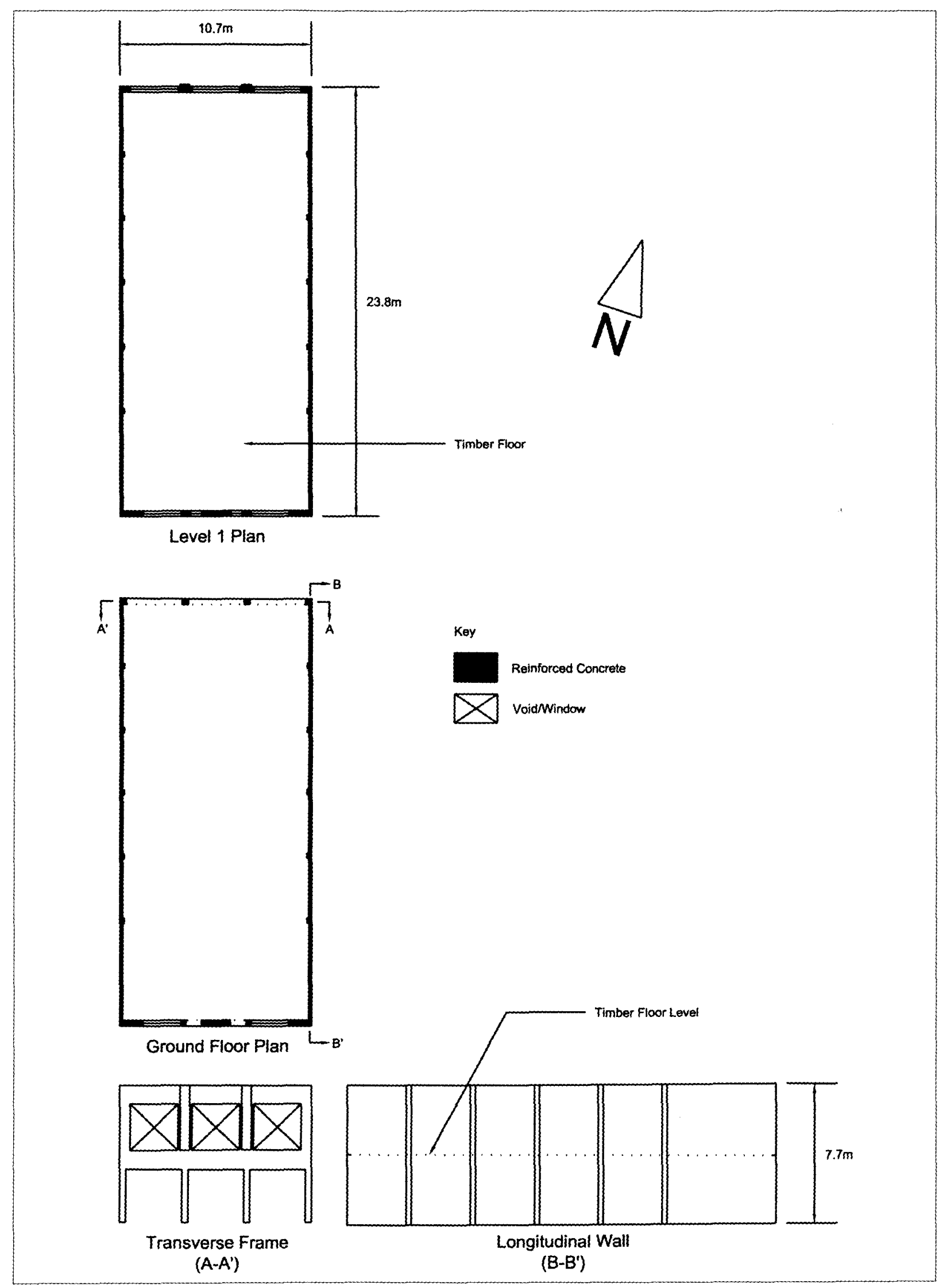

West (JS) \& Co. 


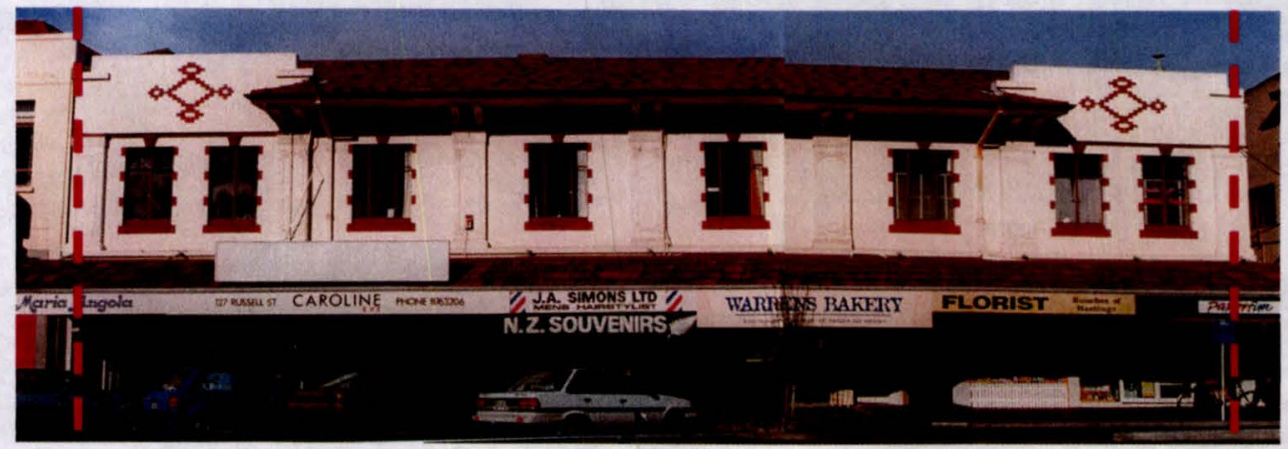

Building Name: Poppelwells

Address: 119-129 Russell Street North, Hastings

Date of Construction: c1930

\section{Primary lateral load resisting structural systems:}

Transverse - Reinforced concrete frames with unreinforced brick masonry infill panels at ground floor level. Unreinforced brick masonry walls at level 1.

Longitudinal - Open reinforced concrete frames at ground floor level. Unreinforced brick masonry walls at level 1 .

Construction: First floor is a reinforced concrete slab. The roof is of timber frame with heavy tile roof. Walls at first floor are of unreinforced brick masonry.

Recorded notes on damage: End gable fell out (Alexander Turnbull Library photo \#4805²/2). Assumptions made in modelling:

- The structural action of the unreinforced masonry walls at first floor level is modelled as one horizontal force applied to the reinforced concrete frame;

- Masonry infill panels in longitudinal frame at rear of building are assumed to have negligible rigidity as there are many penetrations;

- The skewness in the frame is negligible as this angle is not far from that of an orthogonal plan.

\section{Results}

\section{$\underline{\text { Seismic Loads }}$}

The variables for the seismic load calculation are summarised in the table below.

Table 5-16-1 Summary of Seismic Load Variables for Poppelwells building (Transverse and Longitudinal)

\begin{tabular}{|l|l|l|l|}
\hline $\boldsymbol{\mu}$ & $\mathbf{C}$ & $\mathbf{W}_{\mathbf{t}}(\mathbf{k N})$ & $\mathbf{V}(\mathbf{k N})$ \\
\hline 1 & 1.07 & 5726 & 6127 \\
\hline
\end{tabular}


$\underline{\text { Results }}$

Table 5-16-2 Summary of results of transverse infill wall for Poppelwells building

\begin{tabular}{|c|c|c|c|c|c|c|c|c|c|}
\hline \multirow[b]{2}{*}{$\begin{array}{l}\text { Member } \\
\text { Type }\end{array}$} & \multirow[b]{2}{*}{ 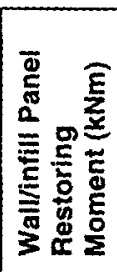 } & \multicolumn{4}{|c|}{ Strength of Infill Panels } & \multirow[b]{2}{*}{ 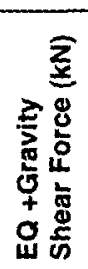 } & \multirow[b]{2}{*}{ 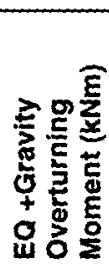 } & \multirow[b]{2}{*}{ 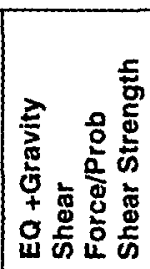 } & \multirow[b]{2}{*}{ 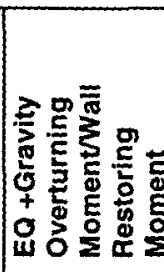 } \\
\hline & & 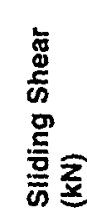 & 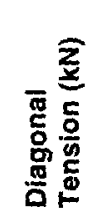 & 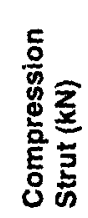 & 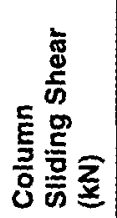 & & & & \\
\hline $\begin{array}{l}\text { Infill } \\
\text { wall, } \\
\text { ground }\end{array}$ & 1900 & 516 & 2163 & 633 & 2078 & 330 & 3410 & 0.64 & 1.79 \\
\hline
\end{tabular}

Table 5-16-3 Summary of results of longitudinal frame for Poppelwells building

\begin{tabular}{|c|c|c|c|c|c|c|}
\hline $\begin{array}{l}\text { Member } \\
\text { Type }\end{array}$ & 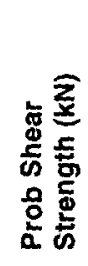 & 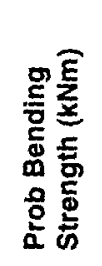 & 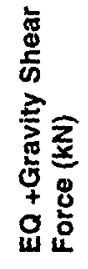 & 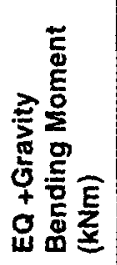 & 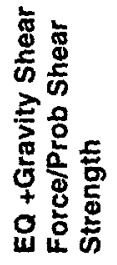 & 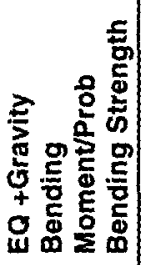 \\
\hline $\begin{array}{l}\text { Column, } \\
\text { ground }\end{array}$ & 112 & 122 & 101 & 175 & 0.90 & 1.43 \\
\hline $\begin{array}{l}\text { Beam, } \\
\text { level } 1\end{array}$ & 135 & 203 & 126 & 150 & 0.93 & 0.74 \\
\hline
\end{tabular}

\section{Discussion}

Transverse: As Table 2 shows, no failure modes were expected to develop in the infill panels. The earthquake bending moment on the wall exceeded the probable restoring moment. There is no recorded evidence of the wall rocking but it could have occurred without being observed.

\section{Results Reliability Rating: B}

Longitudinal: The columns in the longitudinal frame should have yielded according to the analysis but there is no record of columns cracking. Neither the shear forces nor the bending moments exceeded the respective capacities of the beams in these frames.

\section{Results Reliability Rating: B}




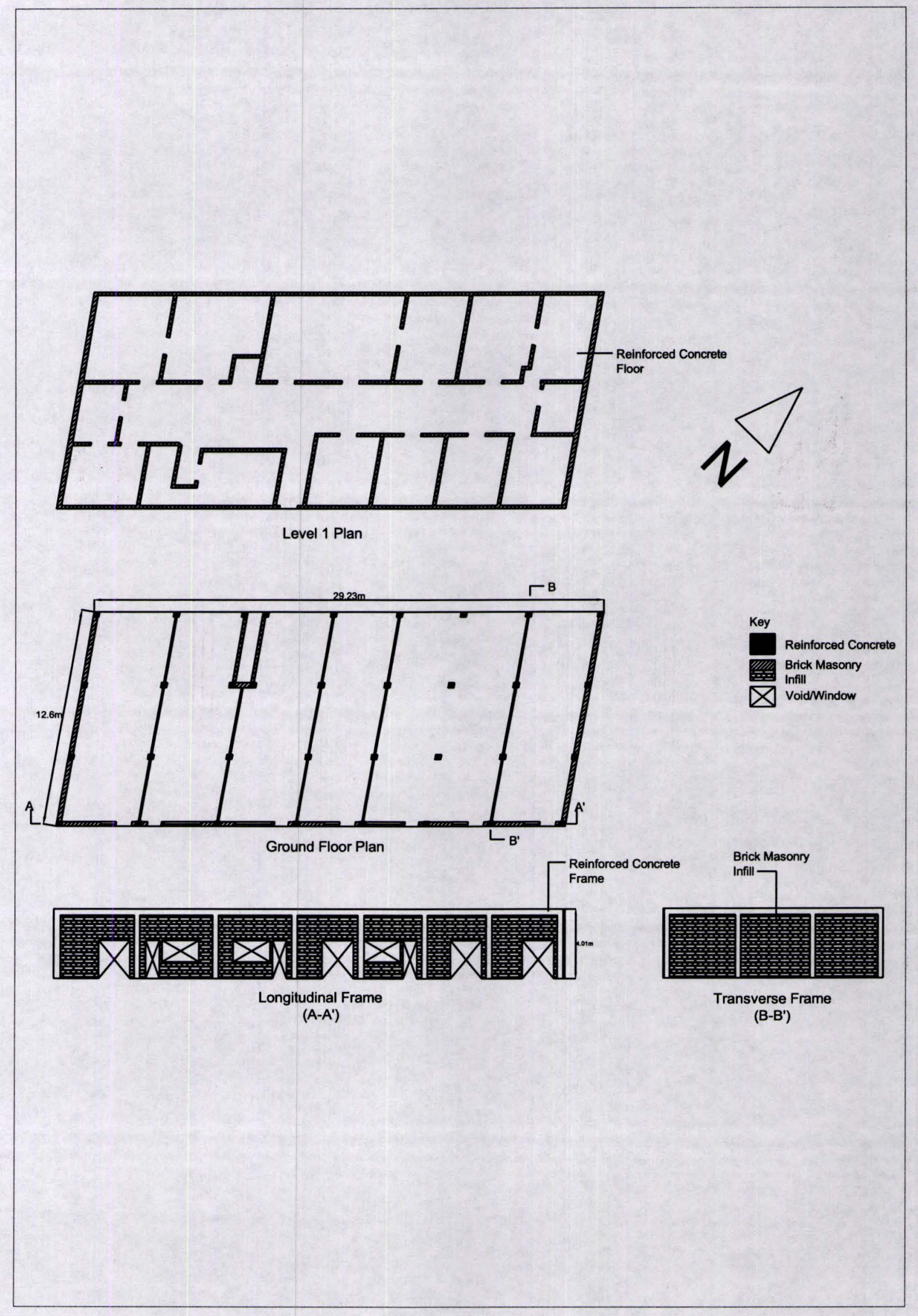

Poppelwells 


\section{Building Description}

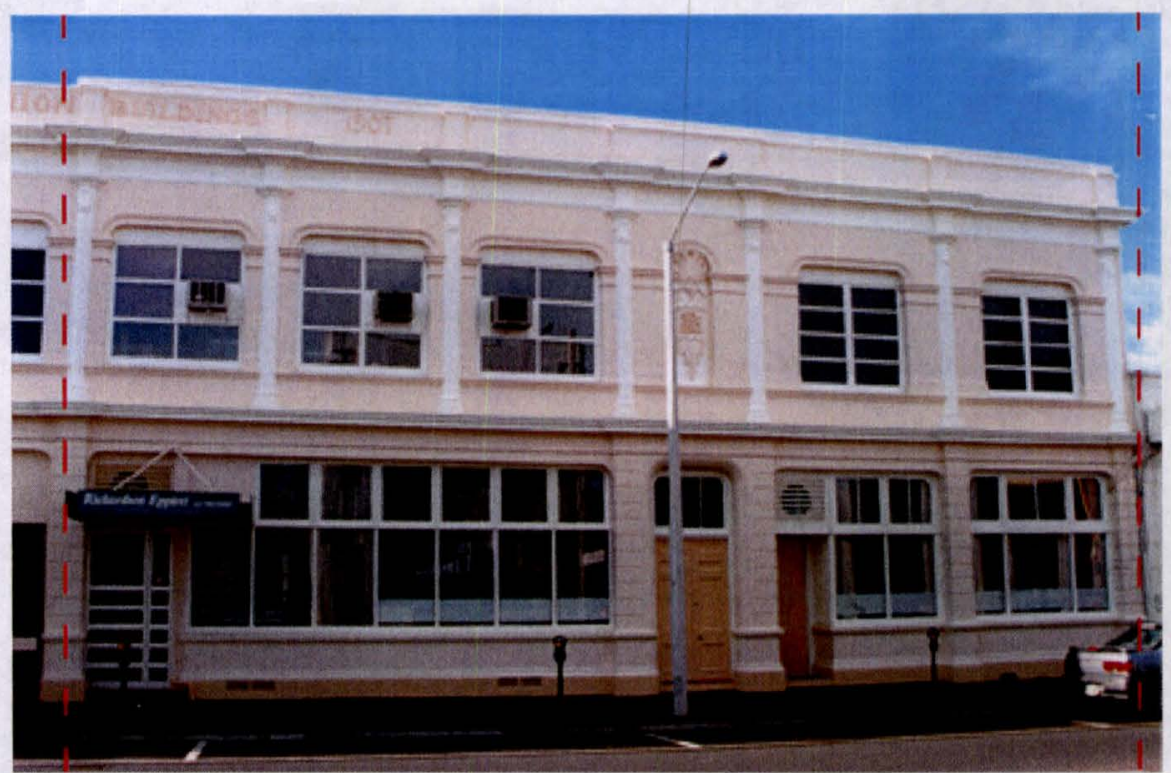

Building Name: Dominion Buildings

Address: 116-120 Queen Street East, Hastings

Date of Construction: 1907

\section{Primary lateral load resisting structural systems:}

Transverse - One reinforced concrete structural wall at ground floor and three reinforced concrete moment resisting frames (two storeyed).

Longitudinal - Five reinforced concrete structural walls, three full length of building, two 60 percent length of building.

Construction: Reinforced concrete first floor and roof. One-way moment resisting frames in transverse direction and structural walls in longitudinal direction support the roof.

Recorded notes on damage: No structural damage.

\section{Assumptions made in modelling:}

- Where the structural walls act as columns in the transverse frames they are assumed to be $2 \mathrm{~m}$ wide;

- An internal structural wall in the longitudinal direction is modelled as part of the primary lateral load resisting structure. The door in this wall, made of steel and of equal thickness as the wall, is assumed to be part of the wall. 
Results

Seismic Loads

The variables for the seismic load calculation are summarised in the table below.

Table 5-17-1 Summary of Seismic Load Variables for Dominion Buildings (Transverse and Longitudinal)

\begin{tabular}{|l|l|l|l|}
\hline $\boldsymbol{\mu}$ & $\mathbf{C}$ & $\mathbf{W}_{\mathbf{t}}(\mathbf{k N})$ & $\mathbf{V}(\mathbf{k N})$ \\
\hline 1 & 1.07 & 8401 & 8989 \\
\hline
\end{tabular}

$\underline{\text { Results }}$

Table 5-17-2 Summary of results of transverse wall for Dominion Buildings

\begin{tabular}{|c|c|c|c|c|c|c|}
\hline $\begin{array}{l}\text { Member } \\
\text { Type }\end{array}$ & 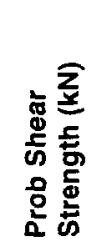 & 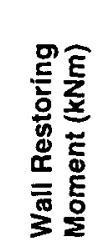 & 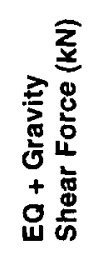 & 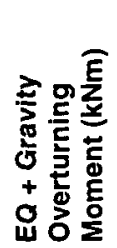 & 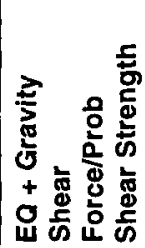 & 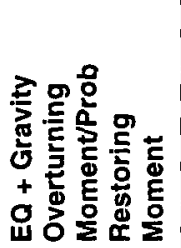 \\
\hline $\begin{array}{l}\text { Structural } \\
\text { wall, } \\
\text { ground }\end{array}$ & 1893 & 3700 & 8911 & 55100 & \begin{tabular}{|l|}
4.47 \\
\end{tabular} & 14.89 \\
\hline
\end{tabular}

Table 3 Summary of results of longitudinal frame for Dominion Buildings

\begin{tabular}{|c|c|c|c|c|c|c|}
\hline $\begin{array}{l}\text { Member } \\
\text { Type }\end{array}$ & 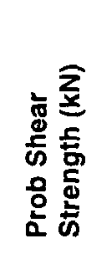 & 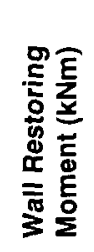 & 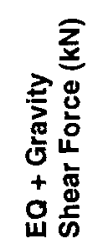 & 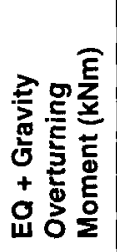 & 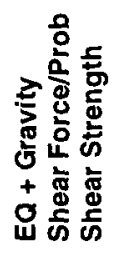 & 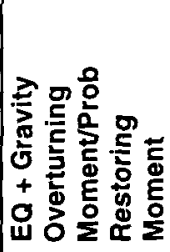 \\
\hline $\begin{array}{l}\text { Structural } \\
\text { wall, } \\
\text { ground- } \\
\text { roof }\end{array}$ & 7203 & 20500 & 2240 & 14600 & 0.31 & 0.71 \\
\hline
\end{tabular}

\section{Discussion}

Transverse: The structural wall in this direction, as the results suggest, should have rocked on its foundations. This building suffered little structural damage but the wall may have rocked without observation.

\section{Results Reliability Rating: B}

Longitudinal: The structural walls, according to the results, should not have suffered any damage due to shear or overturning. The building suffered little structural damage during the earthquake.

\section{Results Reliability Rating: B}




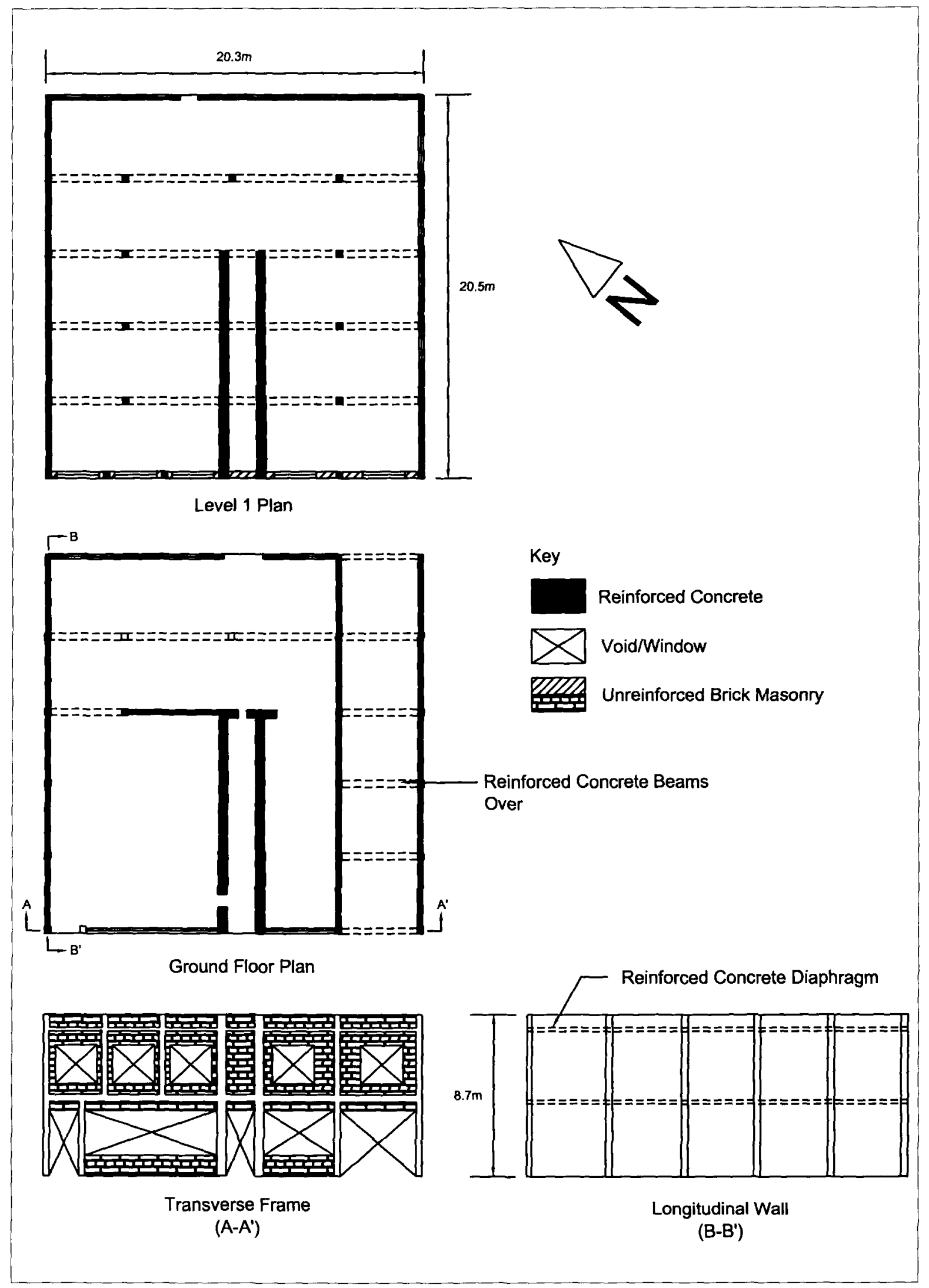

\section{Dominion Buildings}


Building Description

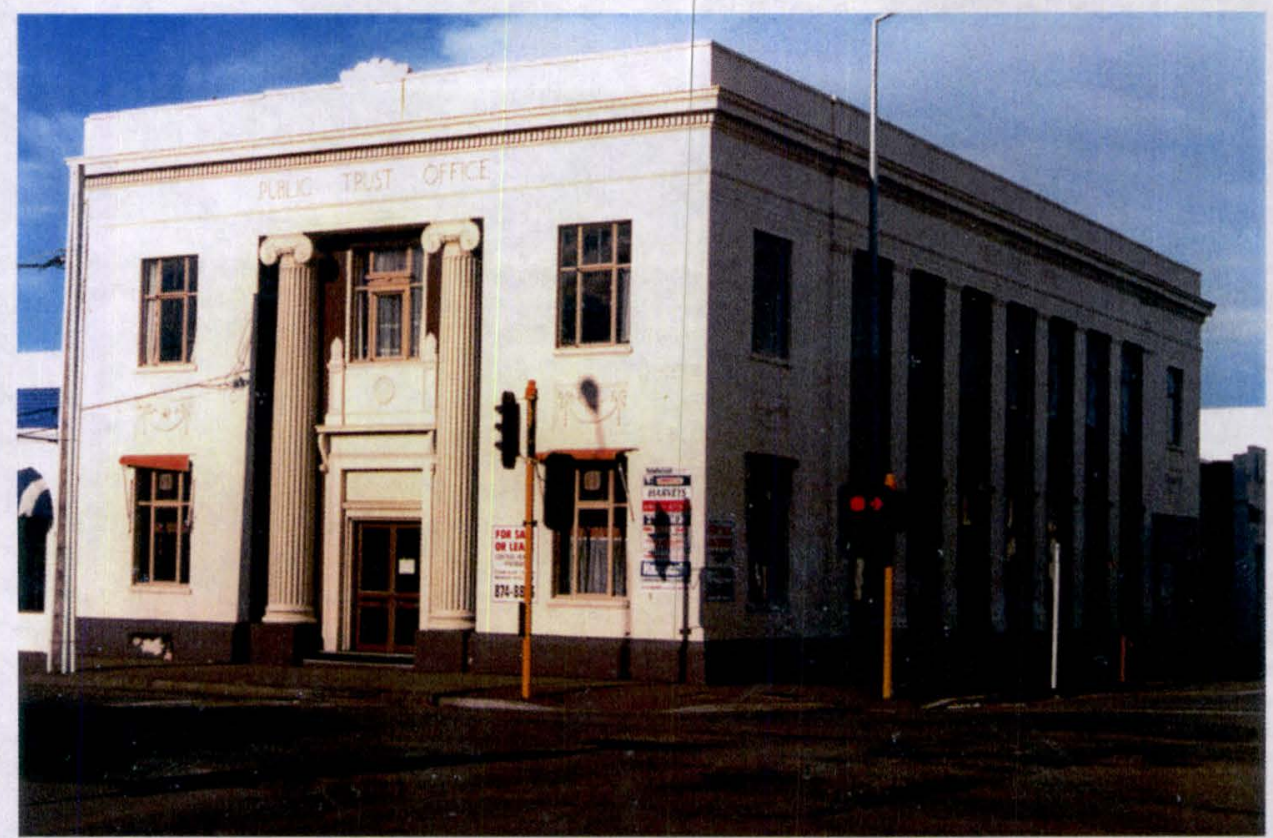

Building Name: Public Trust Office

Address: 201 Karamu Road North, Hastings

Date of Construction: 1925

Primary lateral load resisting structural systems:

Transverse-One internal reinforced concrete structural wall.

Longitudinal - An external reinforced concrete structural wall on the boundary.

Construction: Reinforced concrete floor and roof diaphragms with reinforced concrete beams in transverse direction only. Some internal walls of unreinforced brick masonry (not shown). Street facade in the longitudinal direction is a reinforced concrete moment resisting frame.

Recorded notes on damage: No structural damage.

Assumptions made in modelling:

- The structural walls in both directions resist most of the seismic load. Therefore the moment resisting frames are not analysed;

- The structural walls in the longitudinal direction are modelled as a complete wall. 


\section{Results}

\section{$\underline{\text { Seismic Loads }}$}

The variables for the seismic load calculation are summarised in the table below.

Table 5-18-1 Summary of Seismic Load Variables for Public Trust Office (Hastings) building (Transverse and Longitudinal)

\begin{tabular}{|l|l|l|l|}
\hline $\boldsymbol{\mu}$ & $\mathbf{C}$ & $\mathbf{W}_{\mathbf{t}}(\mathbf{k N})$ & $\mathbf{V}(\mathbf{k N})$ \\
\hline 1 & 1.07 & 6580 & 7041 \\
\hline
\end{tabular}

$\underline{\text { Results }}$

Table 5-18-2 Summary of results of transverse wall for Public Trust Office (Hastings) building

\begin{tabular}{|c|c|c|c|c|c|c|}
\hline $\begin{array}{l}\text { Member } \\
\text { Type }\end{array}$ & 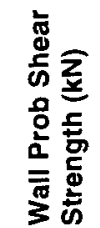 & 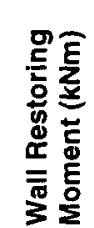 & 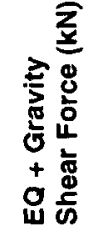 & 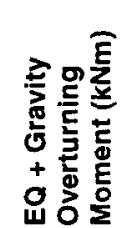 & 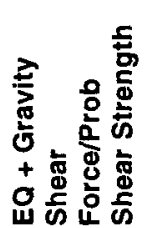 & 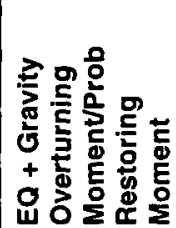 \\
\hline $\begin{array}{l}\text { Structural } \\
\text { wall, } \\
\text { ground- } \\
\text { roof }\end{array}$ & 3540 & 13200 & 7040 & 43000 & $1 . \overline{99}$ & 3.26 \\
\hline
\end{tabular}

Table 5-18-3 Summary of results of longitudinal walls for Public Trust Office (Hastings) building

\begin{tabular}{|c|c|c|c|c|c|c|}
\hline $\begin{array}{l}\text { Member } \\
\text { Type }\end{array}$ & 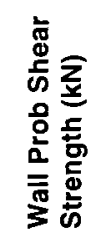 & 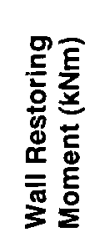 & 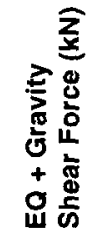 & 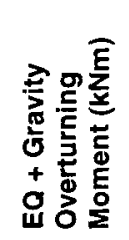 & 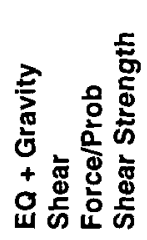 & 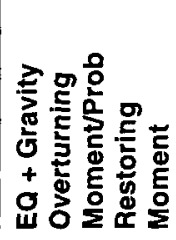 \\
\hline $\begin{array}{l}\text { Structural } \\
\text { wall, } \\
\text { ground- } \\
\text { roof }\end{array}$ & 9140 & 37800 & 7040 & 43000 & 0.77 & 1.14 \\
\hline
\end{tabular}

\section{Discussion}

Transverse: The structural wall in this direction should have rocked on its foundations and failed in shear. Though there was no damage observed to this building.

\section{Results Reliability Rating: B}

Longitudinal: The structural walls in this direction should not have failed in either shear or bending.

\section{Results Reliability Rating: B}




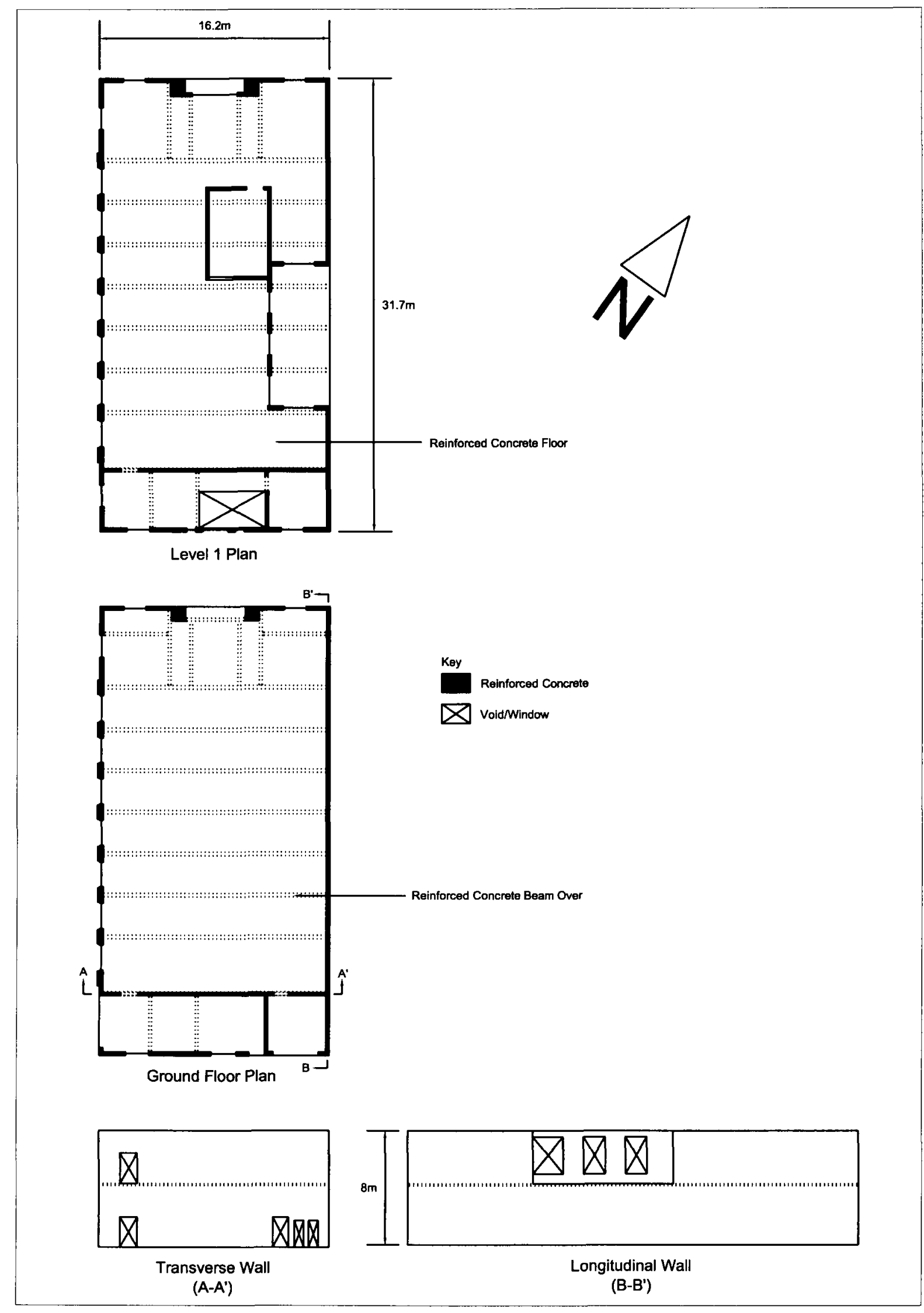

\section{Public Trust Office \\ (Hastings)}


Building Description

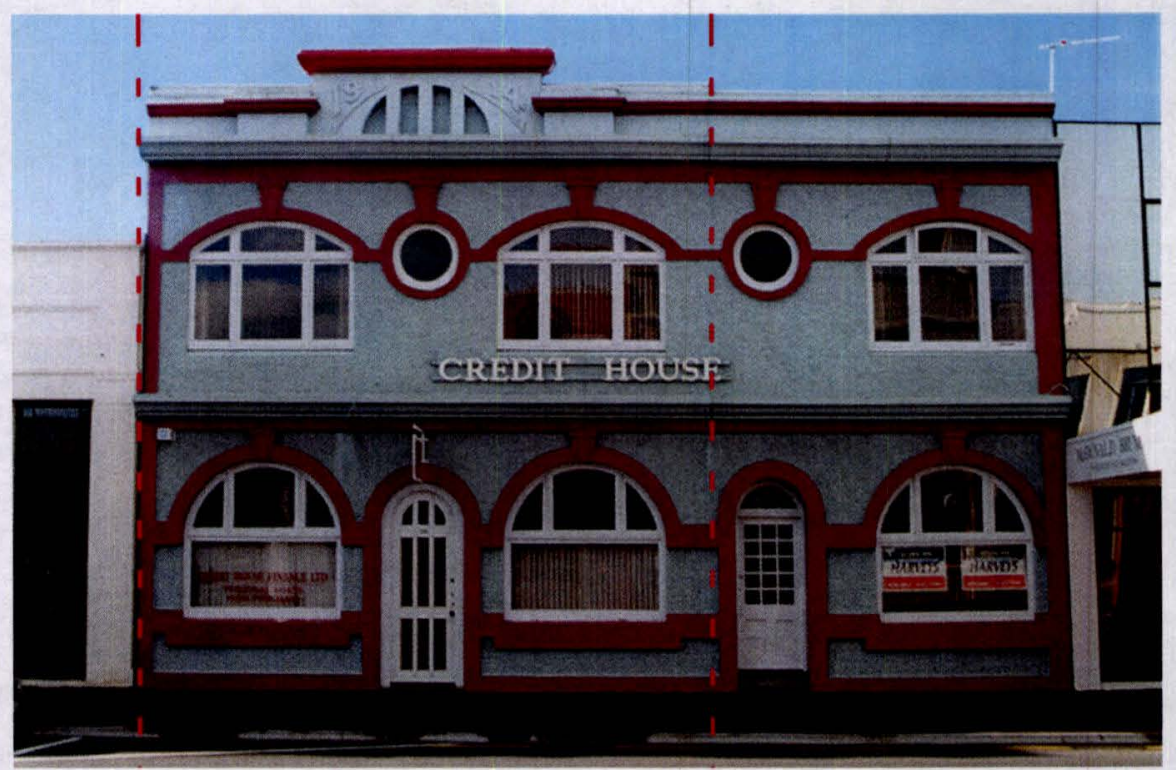

Building Name: Rainbow, Hobbs \& Nesbitt

Address: 126 Queen Street East, Hastings

Date of Construction: 1914

\section{Primary lateral load resisting structural systems:}

Transverse - Two reinforced concrete structural walls and two reinforced concrete moment resisting frames.

Longitudinal - Two full-length and one partial-length reinforced concrete structural walls, all full height of the building. Also two partial-length reinforced concrete structural walls at ground floor only.

Construction: Reinforced concrete floors and roof diaphragms.

Recorded notes on damage: No structural damage.

\section{Assumptions made in modelling:}

- Openings in walls are not included in the models.

Results

\section{$\underline{\text { Seismic Loads }}$}

The variables for the seismic load calculation are summarised in the table below.

Table 5-19-1 Summary of Seismic Load Variables for Rainbow, Hobbs \& Nesbitt building (Transverse and Longitudinal)

\begin{tabular}{|l|l|l|l|}
\hline $\boldsymbol{\mu}$ & $\mathbf{C}$ & $\mathbf{W}_{\mathbf{t}}(\mathbf{k N})$ & $\mathbf{V}(\mathbf{k N})$ \\
\hline 1 & 1.07 & 2320 & 2482 \\
\hline
\end{tabular}


Results

Table 5-19-2 Summary of results of transverse frames and walls for Rainbow, Hobbs \& Nesbitt building

\begin{tabular}{|c|c|c|c|c|c|c|c|c|c|}
\hline $\begin{array}{l}\text { Member } \\
\text { Type }\end{array}$ & 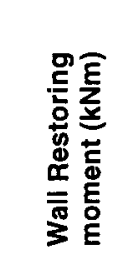 & 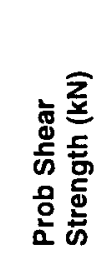 & 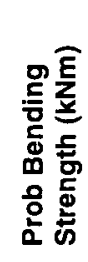 & 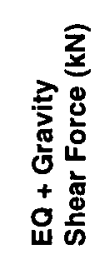 & 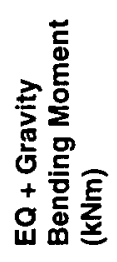 & 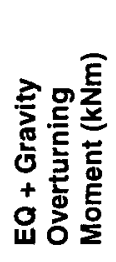 & 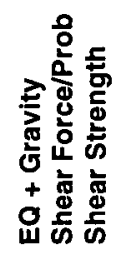 & 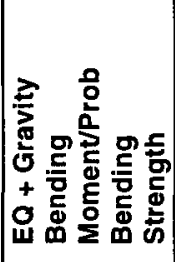 & 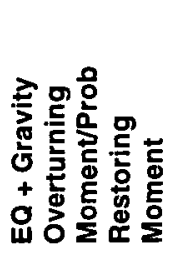 \\
\hline $\begin{array}{l}\text { Structural } \\
\text { wall, ground- } \\
\text { roof }\end{array}$ & 848 & 827 & & 709 & & 2960 & 0.86 & & 3.49 \\
\hline $\begin{array}{l}\text { Column, } \\
\text { ground }\end{array}$ & & 365 & 103 & 198 & 274 & & 0.54 & 2.66 & \\
\hline Beam, level 1 & & 443 & 105 & 486 & 332 & & 1.10 & 3.16 & \\
\hline $\begin{array}{l}\text { Column, } \\
\text { level } 1\end{array}$ & & 351 & 103 & 245 & 320 & & 0.70 & 3.11 & \\
\hline
\end{tabular}

Table 5-19-3 Summary of results of longitudinal walls for Rainbow, Hobbs \& Nesbitt building

\begin{tabular}{|c|c|c|c|c|c|c|}
\hline Member Type & 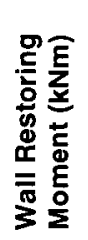 & 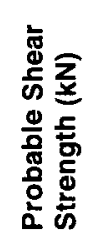 & 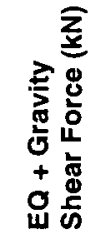 & 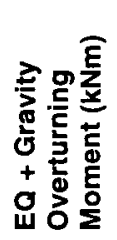 & 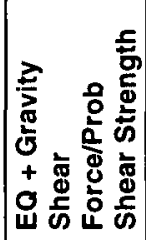 & 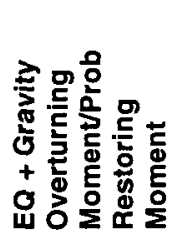 \\
\hline $\begin{array}{l}\text { Structural } \\
\text { wall, ground }\end{array}$ & 917 & 1630 & 249 & 843 & 0.15 & 0.92 \\
\hline $\begin{array}{l}\text { Structural } \\
\text { wall, ground- } \\
\text { roof }\end{array}$ & 6690 & 4180 & 1010 & 6000 & 0.24 & 0.90 \\
\hline $\begin{array}{l}\text { Structural } \\
\text { wall, ground- } \\
\text { roof }\end{array}$ & 6690 & 4180 & 1040 & 6240 & 0.25 & 0.93 \\
\hline
\end{tabular}

\section{Discussion}

Transverse: The structural walls in this direction should have rocked on their foundations.

The walls may have rocked without observation and without causing structural damage. The columns at ground floor and beams and columns at level 1 should have suffered some concrete cracking due to yielding of the reinforcing steel. None of the beams and columns failed in shear. There was little reported structural damage to this building.

\section{Results Reliability Rating: B}

Longitudinal: None of the structural walls in this direction should have suffered damage from either shear or overturning failure.

\section{Results Reliability Rating: B}




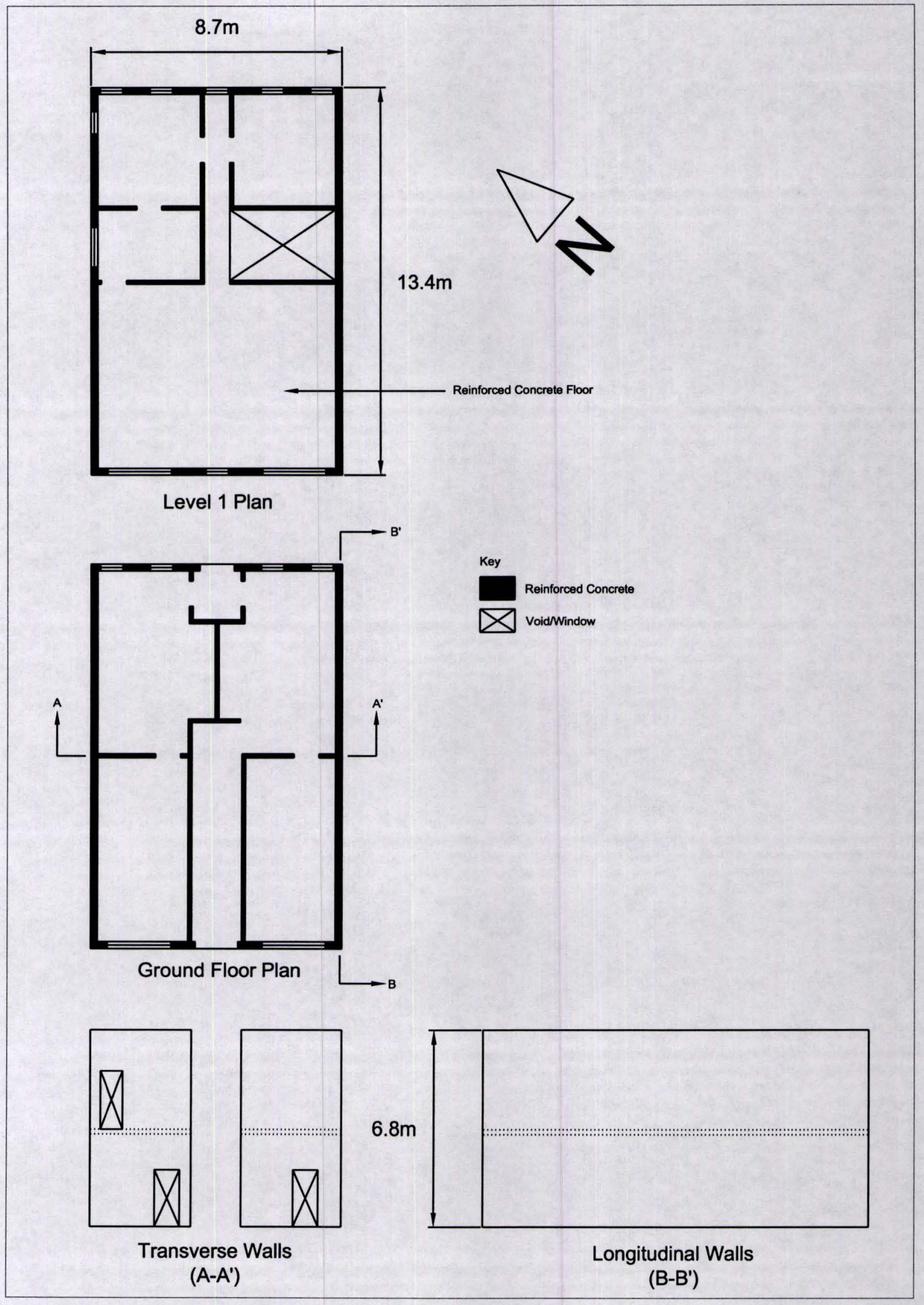

Rainbow, Hobbs \& Nesbitt 


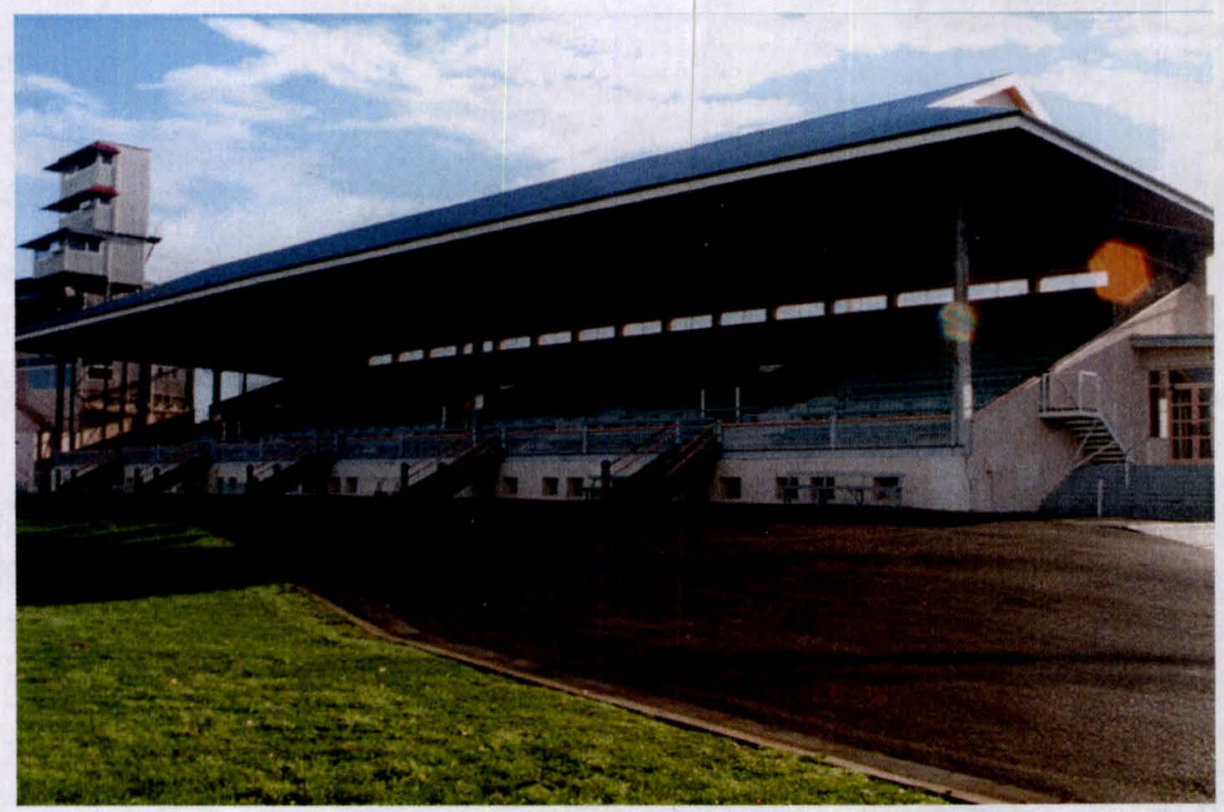

Building Name: Hawke's Bay Jockey Club Racecourse - Steward Stand

Address: 601 Market Street South, Hastings

Date of Construction: 1920

Primary lateral load resisting structural systems:

Transverse - Fifteen reinforced concrete columns.

Longitudinal - One reinforced concrete moment resisting frame with two bays of unreinforced brick masonry infill.

Construction: Lightweight timber floors, supported on Level 1 by timber beams and columns and supported on Level 2 by steel trusses. Lightweight timber frame and corrugated steel roof supported by steel trusses and steel columns. The structure is three storeys at the rear and a retaining wall approx $1.3 \mathrm{~m}$ above ground at the front.

Recorded notes on damage: Small localised cracking of brickwork Stub columns at front of grandstand sheared through. Sidewalls cracked also. Roof truss dislodged and sidewall below cracked and broken (Alexander Turnbull Library photos \#1545491/2, five others (not labelled)).

\section{Assumptions made in modelling:}

- Three-storey moment resisting frame resists all of the seismic force in the longitudinal direction;

- The sidewalls, made of unreinforced brick masonry, are modelled as diagonal struts between the retaining wall and the reinforced concrete columns (see Appendix B). 


\section{Results}

\section{$\underline{\text { Seismic Loads }}$}

The variables for the seismic load calculation are summarised in the table below.

Table 5-20-1 Summary of Seismic Load Variables for HB Jockey Club - Steward Stand building (Transverse and Longitudinal)

\begin{tabular}{|l|l|l|l|}
\hline $\boldsymbol{\mu}$ & $\mathbf{C}$ & $\mathbf{W}_{\mathbf{t}}(\mathbf{k N})$ & $\mathbf{V}(\mathbf{k N})$ \\
\hline 1 & 1.07 & 12381 & 18286 \\
\hline
\end{tabular}

$\underline{\text { Results }}$

Table 5-20-2 Summary of results of transverse frame for HB Jockey Club - Steward Stand building

\begin{tabular}{|c|c|c|c|c|c|c|c|c|c|c|}
\hline \multirow[b]{2}{*}{ Member Type } & \multirow[b]{2}{*}{ 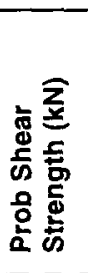 } & \multirow[b]{2}{*}{ 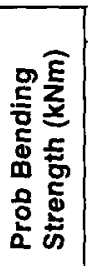 } & \multicolumn{4}{|c|}{ Strength of infill Panels } & \multirow[b]{2}{*}{ 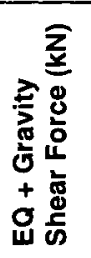 } & \multirow[b]{2}{*}{ 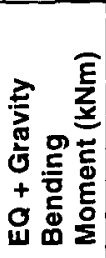 } & \multirow[b]{2}{*}{ 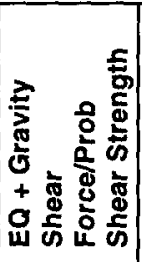 } & \multirow[b]{2}{*}{ 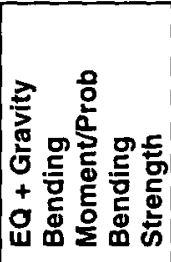 } \\
\hline & & & 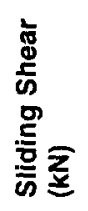 & 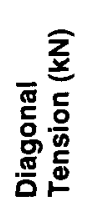 & 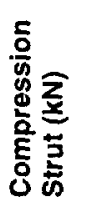 & 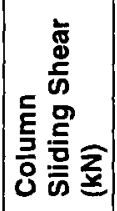 & & & & \\
\hline Infill panels, ground & & & 1710 & 2880 & 4440 & 1330 & 6620 & & 4.18 & \\
\hline Column, ground-roof & 293 & 209 & & & & & 2760 & 6890 & 9.42 & 32.97 \\
\hline
\end{tabular}

Table 5-20-3 Summary of results of longitudinal infill wall for HB Jockey Club - Steward Stand building

\begin{tabular}{|c|c|c|c|c|c|c|c|c|c|}
\hline \multirow[b]{2}{*}{ Member Type } & \multirow[b]{2}{*}{ 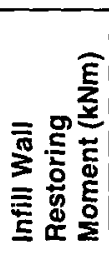 } & \multicolumn{4}{|c|}{ Strength of Infill Panels } & \multirow[b]{2}{*}{ 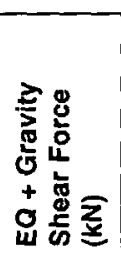 } & \multirow[b]{2}{*}{ 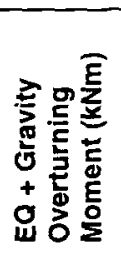 } & \multirow[b]{2}{*}{ 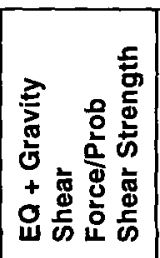 } & \multirow[b]{2}{*}{ 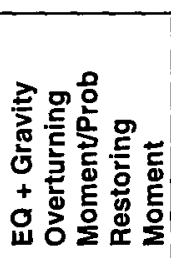 } \\
\hline & & 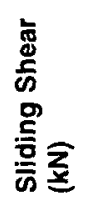 & 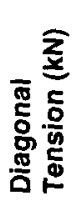 & 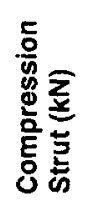 & 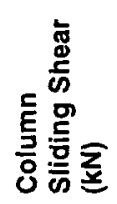 & & & & \\
\hline Infill wall, ground-roof & 5025 & 836 & 953 & 4510 & 11773 & 18286 & 153111 & 11.83 & 30.47 \\
\hline
\end{tabular}

\section{Discussion}

Transverse: The adjacent column-top of the infill frame should have failed in shear. The recorded damage shows the column that failed in shear was the stub-column at the front of the stand, not the two-storey column at the rear, as Table 5-20-2 suggests.

\section{Results Reliability Rating: C}

Longitudinal: Table 5-20-3 shows that the infill wall should have rocked before the infill panels should have failed in shear. The damage records do not show either of these to have occurred. The high overturning ratio is due to the slenderness ratio and seismic weight on the wall.

\section{Results Reliability Rating: C}




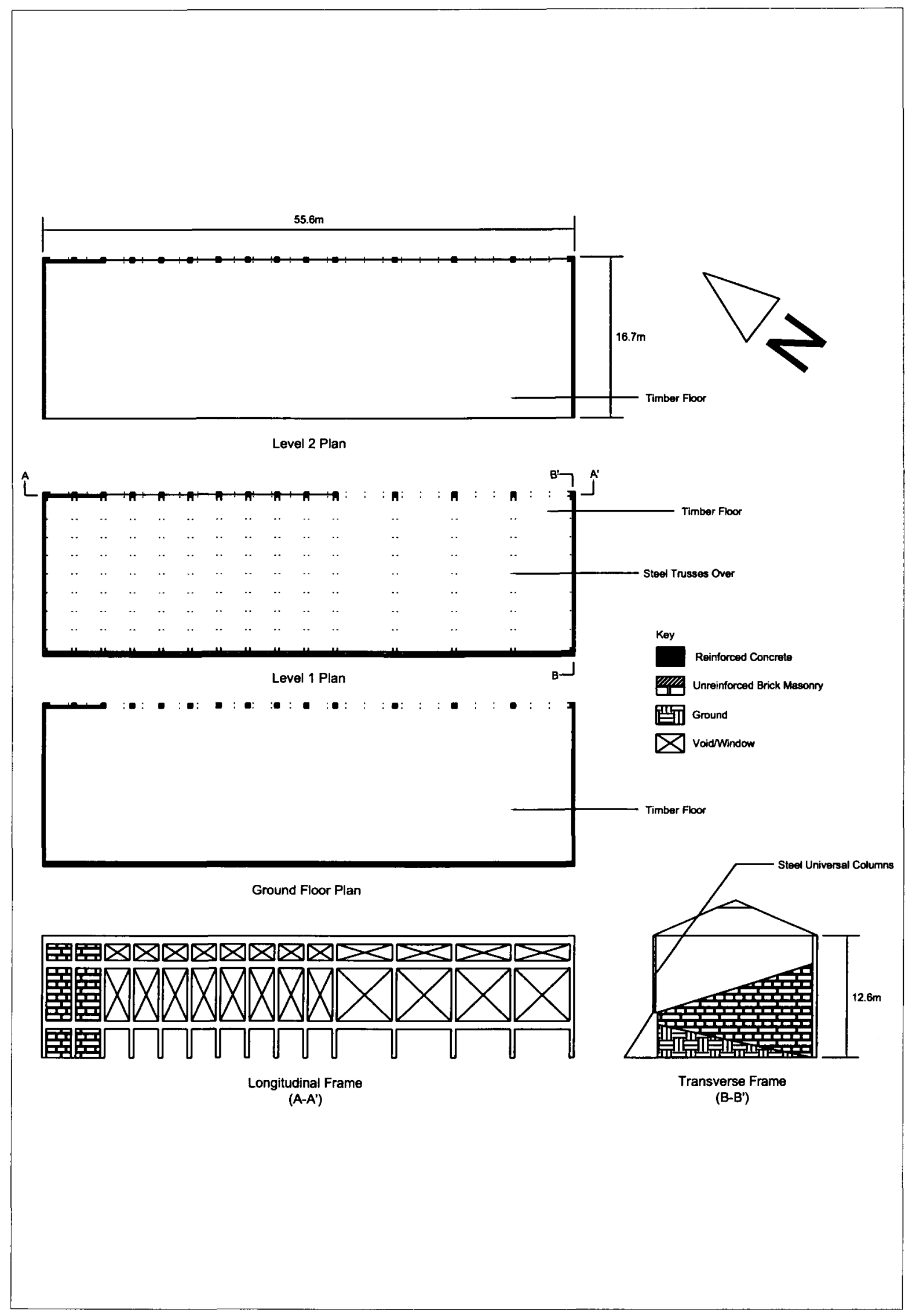

\section{Hawke's Bay Jockey Club Racecourse Steward Stand}




\section{Building Description}

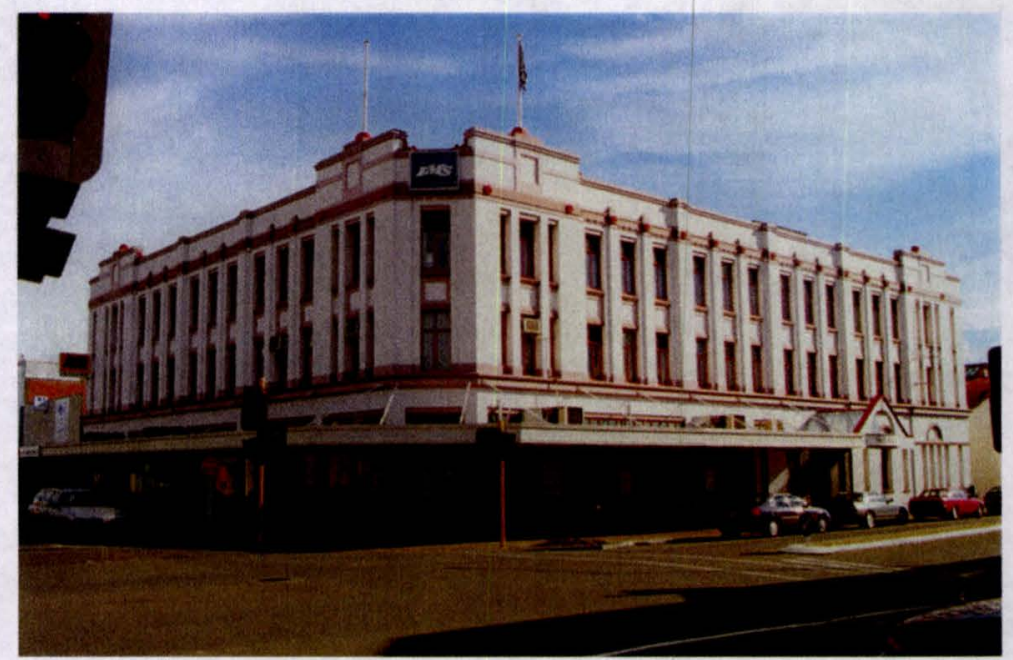

Building Name: Hawke's Bay Farmers Co-Operative

Address: 120-124 Market Street North, Hastings

Date of Construction: $\mathrm{c} 1931$

\section{Primary lateral load resisting structural systems:}

Transverse - Two reinforced concrete moment resisting frames with some unreinforced brick masonry infill panels.

Longitudinal - One reinforced concrete moment resisting frame with unreinforced brick masonry infill panels (West facade).

Construction: Reinforced concrete floors and roof. Highly penetrated unreinforced brick masonry infill panels to all bays except to West Facade. Internal structure is flat slab. Basement is one floor deep, similar construction.

Recorded notes on damage: Stone facings of shop fronts loosened, hair cracks in concrete (Dowrick, 1998).

\section{Assumptions made in modelling:}

- Penetrations to infill panels to West facade are ignored to simplify the model;

- Infill panels in the moment resisting frames on North, East and South facades are ignored, due to many penetrations, with the exception of the two largest panels at ground floor level on the North facade;

- The basement is ignored. The perimeter frames, the primary lateral load resisting structure, sit on perimeter walls adjacent to solid ground;

- Internal unreinforced brick masonry infill panels in transverse direction, that fill an entire bay, are modelled within a single transverse frame (North facade). 


\section{Results}

$\underline{\text { Seismic Loads }}$

The variables for the seismic load calculation are summarised in the table below.

Table 5-21-1 Summary of Seismic Load Variables for HB Farmers Co-Op building (Transverse and Longitudinal)

\begin{tabular}{|l|l|l|l|}
\hline $\boldsymbol{\mu}$ & $\mathbf{C}$ & $\mathbf{W}_{\mathbf{t}}(\mathbf{k N})$ & $\mathbf{V}(\mathbf{k N})$ \\
\hline 1 & 1.07 & 22300 & 23861 \\
\hline
\end{tabular}

\section{$\underline{\text { Results }}$}

Table 5-21-2 Summary of results of transverse frame for HB Farmers Co-Op building

\begin{tabular}{|c|c|c|c|c|c|c|c|c|c|c|}
\hline \multirow[b]{2}{*}{ Member Type } & \multirow[b]{2}{*}{ 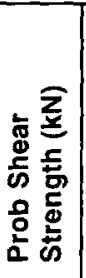 } & \multirow[b]{2}{*}{ 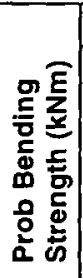 } & \multicolumn{4}{|c|}{ Strength of Infill Panels } & \multirow[b]{2}{*}{ 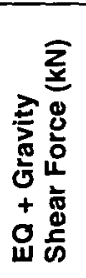 } & \multirow[b]{2}{*}{ 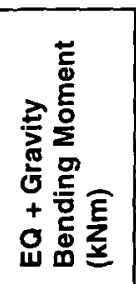 } & \multirow[b]{2}{*}{ 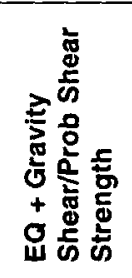 } & \multirow{2}{*}{ 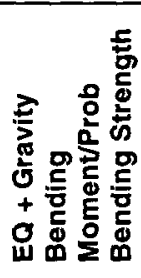 } \\
\hline & & & 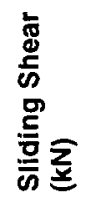 & 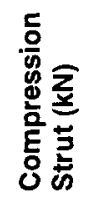 & 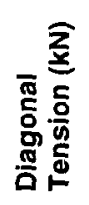 & 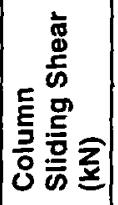 & & & & \\
\hline Infill panel, ground & & & 1037 & 1472 & 5266 & 6703 & 5740 & & 5.54 & \\
\hline Column, ground & 215 & 190 & & & & & 466 & 749 & 2.17 & 3.94 \\
\hline Beam, level 1 & 315 & 362 & & & & & 569 & 789 & 1.81 & 2.18 \\
\hline Column, level 1 & 215 & 190 & & & & & 2 & 33 & 0.01 & 0.17 \\
\hline Beam, level 2 & 315 & 362 & & & & & 473 & 602 & 1.50 & 1.66 \\
\hline Column, level 2 & 215 & 190 & & & & & 402 & 511 & 1.87 & 2.69 \\
\hline Beam, roof & 315 & 362 & & & & & 448 & 625 & $1 . \overline{42}$ & 1.73 \\
\hline
\end{tabular}

Table 5-21-3 Summary of results of longitudinal infill frame for HB Farmers Co-Op building

\begin{tabular}{|c|c|c|c|c|c|c|c|c|c|}
\hline \multirow[b]{2}{*}{ Member Type } & \multirow[b]{2}{*}{ 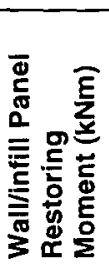 } & \multicolumn{4}{|c|}{ Strength of Infill Panels } & \multirow[b]{2}{*}{ 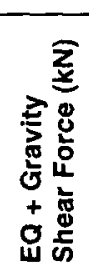 } & \multirow[b]{2}{*}{ 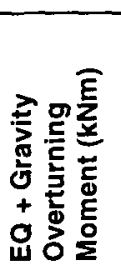 } & \multirow[b]{2}{*}{ 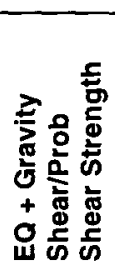 } & \multirow[b]{2}{*}{ 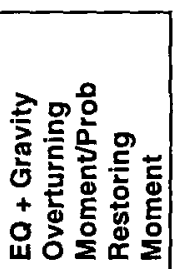 } \\
\hline & & 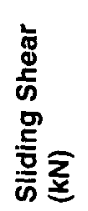 & 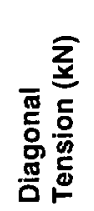 & 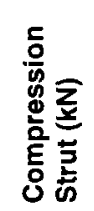 & 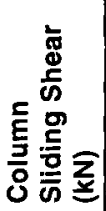 & & & & \\
\hline Infill wall, ground-level 2 & 281000 & 7586 & 10853 & 21061 & 8647 & 4194 & 146000 & 0.55 & 0.52 \\
\hline
\end{tabular}

$\underline{\text { Discussion }}$

Transverse: The infill panels at ground floor should have failed in shear. Some of the columns should have suffered some damage due to bending. The evidence of "hair-cracks in concrete" could support these findings.

\section{Results Reliability Rating: B}

Longitudinal: The results suggest that sliding shear of the infill panels should have occurred.

There was no damage of this type to this building reported.

\section{Results Reliability Rating: B}




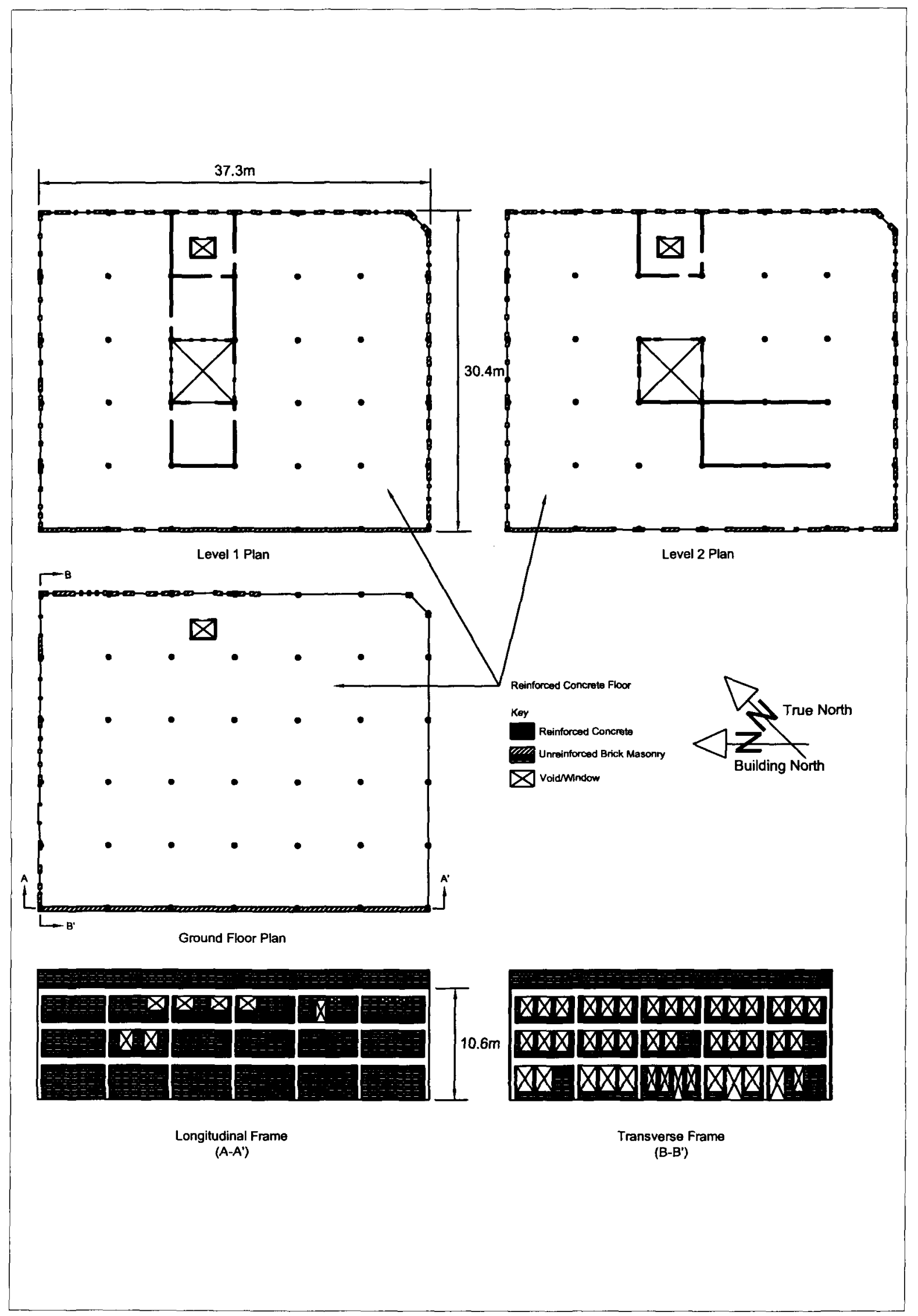

Hawke's Bay Farmers Co-Operative 


\section{Building Description}

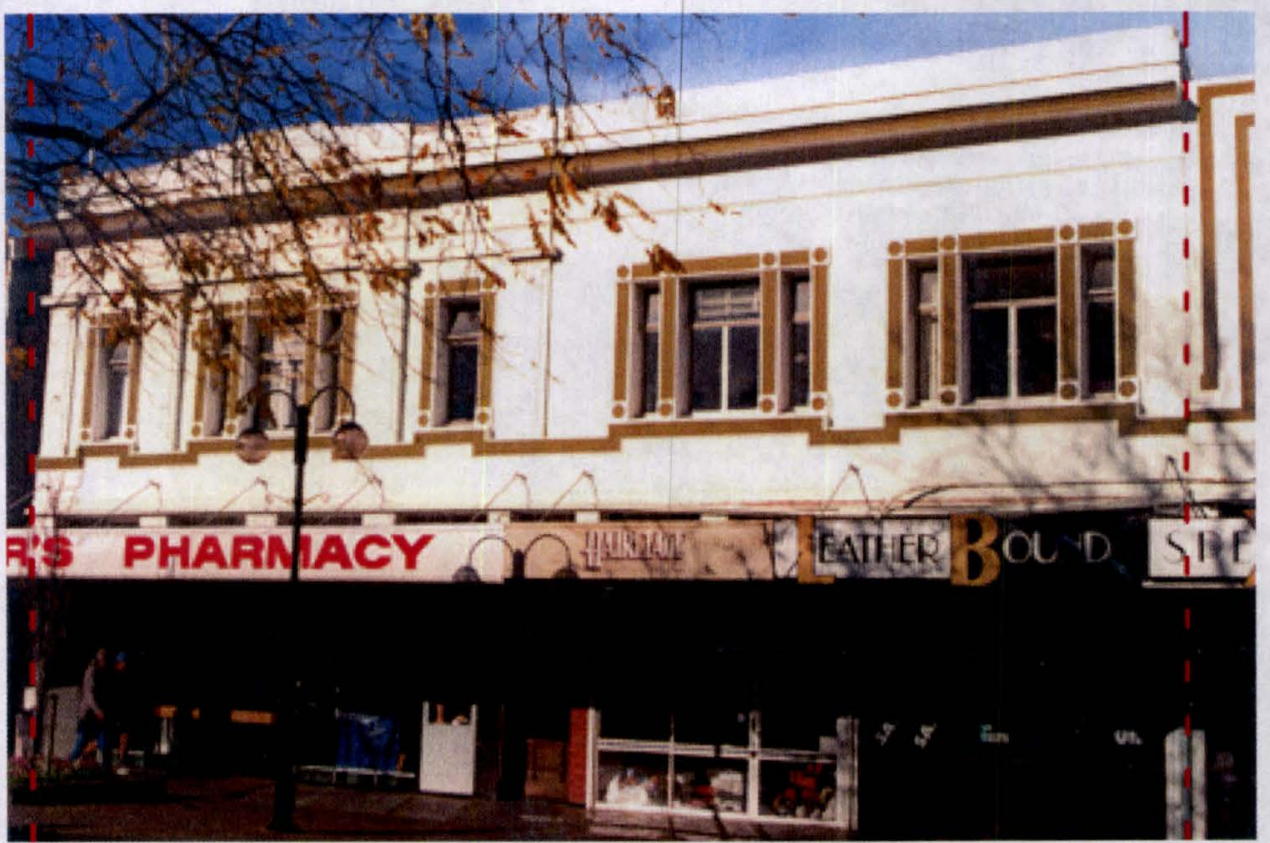

Building Name: Webber's Buildings

Address: 117 Russell Street North, Hastings

Date of Construction: 1927

\section{Primary lateral load resisting structural systems:}

Transverse - Three reinforced concrete moment resisting frames with unreinforced brick masonry infill panels, some of which have penetrations of various sizes.

Longitudinal - Four reinforced concrete moment resisting frames with unreinforced brick masonry infill panels, some of which have penetrations of various sizes. One frame only goes to Level 1; others are full height.

Construction: Reinforced concrete floor and a lightweight timber framed corrugated steel roof. Reinforced concrete stairs to Level 1.

Recorded notes on damage: No structural damage.

\section{Assumptions made in modelling:}

- The skewness in the frame is negligible as this angle is not far from that of an orthogonal plan. 


\section{Results}

\section{$\underline{\text { Seismic Loads }}$}

The variables for the seismic load calculation are summarised in the table below.

Table 5-22-1 Summary of Seismic Load Variables for Webber's Building (Transverse and Longitudinal)

\begin{tabular}{|l|l|l|l|}
\hline $\boldsymbol{\mu}$ & $\mathbf{C}$ & $\mathbf{W}_{\mathbf{t}}(\mathbf{k N})$ & $\mathbf{V}(\mathbf{k N})$ \\
\hline 1 & 1.07 & 3849 & 4118 \\
\hline
\end{tabular}

\section{$\underline{\text { Results }}$}

Table 5-22-2 Summary of results of transverse infill walls for Webber's Building

\begin{tabular}{|c|c|c|c|c|c|c|c|c|c|}
\hline \multirow[b]{2}{*}{$\begin{array}{l}\text { Member } \\
\text { Type }\end{array}$} & \multirow[b]{2}{*}{ 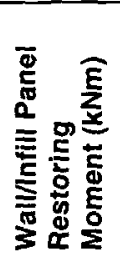 } & \multicolumn{4}{|c|}{ Strength of Infill Panels } & \multirow[b]{2}{*}{ 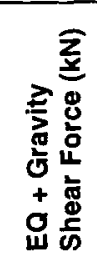 } & \multirow[b]{2}{*}{ 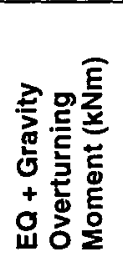 } & \multirow[b]{2}{*}{ 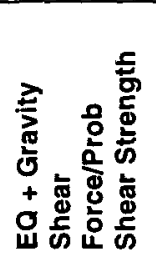 } & \multirow[b]{2}{*}{ 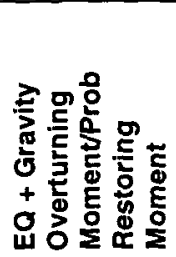 } \\
\hline & & 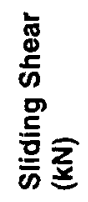 & 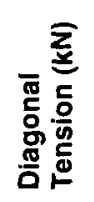 & 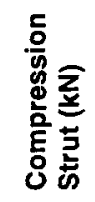 & 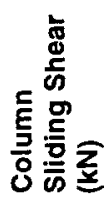 & & & & \\
\hline $\begin{array}{l}\text { Infill wall, } \\
\text { ground-roof }\end{array}$ & 2370 & 2130 & 1700 & 11600 & 2240 & 1590 & 15200 & 0.94 & 6.41 \\
\hline $\begin{array}{l}\text { Infill wall, } \\
\text { ground-roof }\end{array}$ & 1090 & 793 & 1130 & 3660 & 559 & 1700 & 12100 & 3.04 & 11.10 \\
\hline
\end{tabular}

Table 5-22-3 Summary of results of longitudinal infill wall for Webber's Building

\begin{tabular}{|c|c|c|c|c|c|c|c|c|c|}
\hline \multirow[b]{2}{*}{$\begin{array}{l}\text { Member } \\
\text { Type }\end{array}$} & \multirow[b]{2}{*}{ 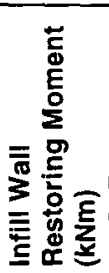 } & \multicolumn{4}{|c|}{ Strength of Infill Panels } & \multirow[b]{2}{*}{ 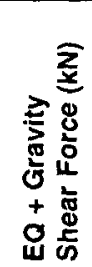 } & \multirow[b]{2}{*}{ 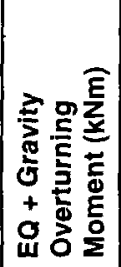 } & \multirow[b]{2}{*}{ 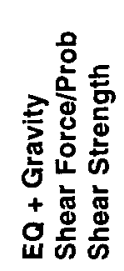 } & \multirow[b]{2}{*}{ 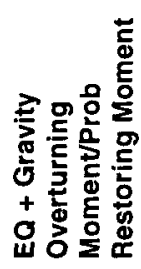 } \\
\hline & & 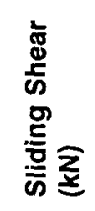 & 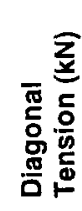 & 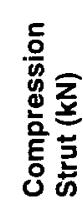 & 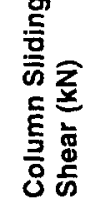 & & & & \\
\hline $\begin{array}{l}\text { Infill wall, } \\
\text { ground }\end{array}$ & 2500 & 1270 & 1650 & 6620 & 942 & 4120 & 8510 & 4.37 & 3.40 \\
\hline
\end{tabular}

\section{Discussion}

Transverse: The results indicate that the infill walls should have rocked on their foundations. There was apparently little structural damage.

\section{Results Reliability Rating: C}

Longitudinal: The infill panels should have failed through sliding shear failure of the adjacent column-top before the infill wall may have rocked. This may have occurred without observation, as the damage records do not mention this.

\section{Results Reliability Rating: C}




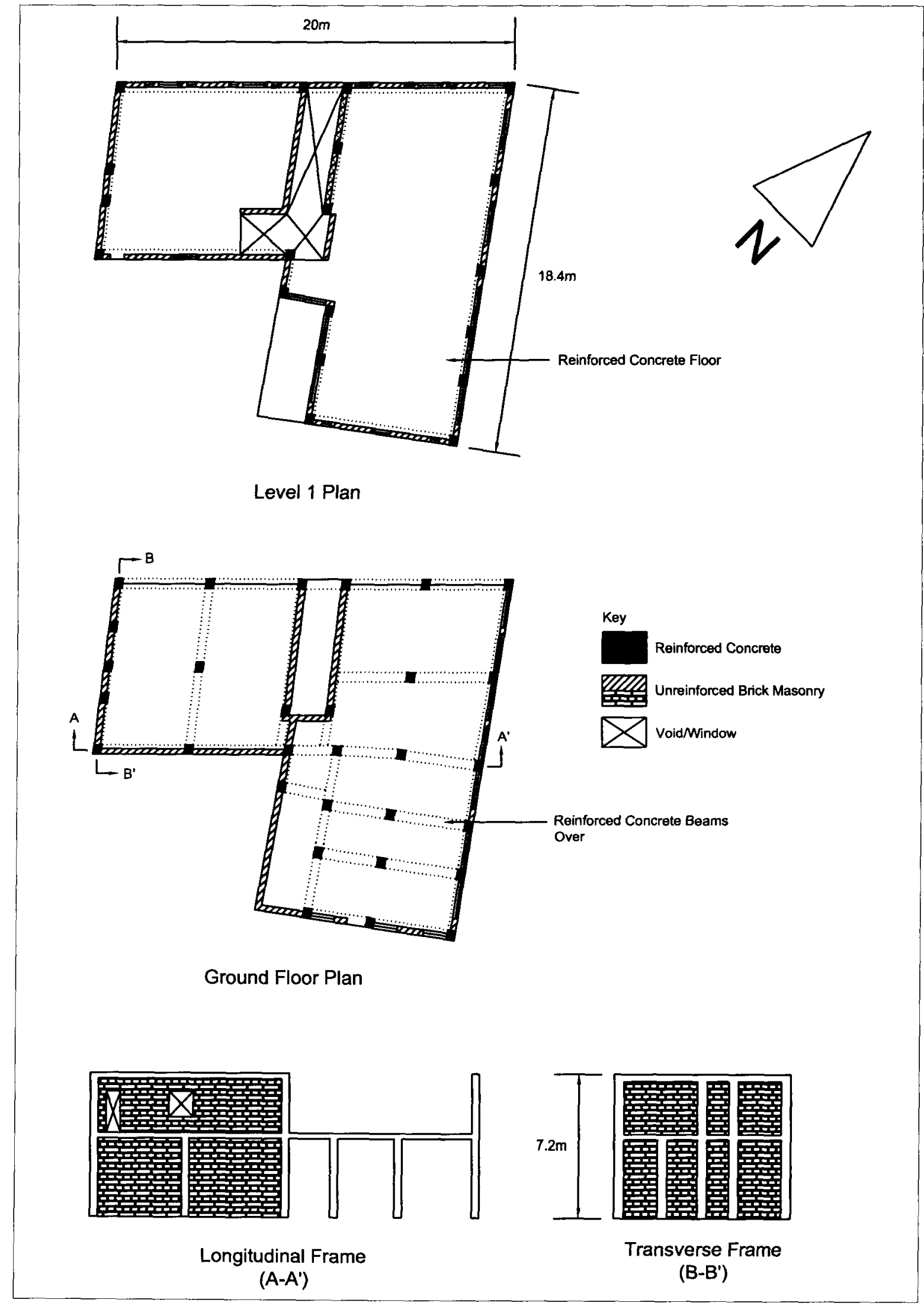

Webber's Buildings 


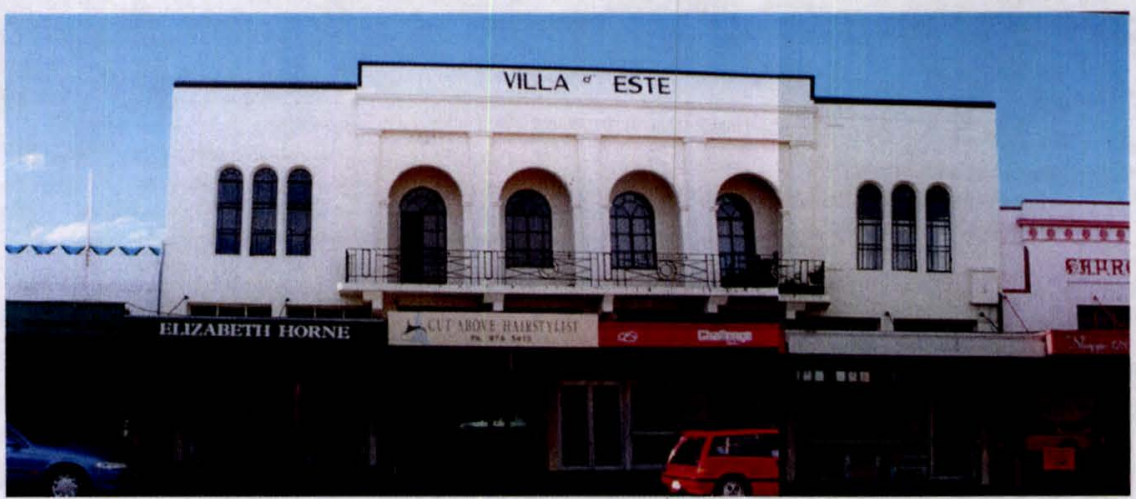

Building Name: Villa d'Este

Address: 331-333 Heretaunga Street, Hastings

Date of Construction: 1929

\section{Primary lateral load resisting structural systems:}

Transverse - Open reinforced concrete frames at ground floor level. Level 1 has unreinforced brick masonry walls.

Longitudinal - Reinforced concrete frames with unreinforced brick masonry infill panels at ground floor level. Level 1 has unreinforced brick masonry walls.

Construction: First floor is a reinforced concrete slab. The roof is of timber frame with lightweight corrugated steel roof. Walls at first floor are of unreinforced brick masonry.

Recorded notes on damage: Badly cracked; Original facade from level 1 to roof fell, awning fell (Dowrick, 1998).

\section{Assumptions made in modelling:}

- The structural action of the unreinforced masonry walls at level 1 is modelled as one horizontal force to the reinforced concrete frame;

- Masonry infill panels in longitudinal frame at rear of building are assumed to have negligible rigidity as there are many penetrations (including clear-storey windows) so are excluded;

- The single storey portion at the rear of the building, of unreinforced masonry with a lightweight timber frame roof, is excluded from the analysis because it is relatively flexible and therefore not capable of transferring horizontal shear to the unreinforced masonry walls. 


\section{Results}

$\underline{\text { Seismic Loads }}$

The variables for the seismic load calculation are summarised in the table below.

Table 5-23-1 Summary of Seismic Load Variables for Villa d'Este building (Transverse and Longitudinal)

\begin{tabular}{|l|l|l|l|}
\hline $\boldsymbol{\mu}$ & $\mathbf{C}$ & $\mathbf{W}_{\mathbf{t}}(\mathbf{k N})$ & $\mathbf{V}(\mathbf{k N})$ \\
\hline 1 & 1.07 & 7907 & 8460 \\
\hline
\end{tabular}

\section{$\underline{\text { Results }}$}

Table 5-23-2 Summary of results of transverse frame for Villa d'Este building

\begin{tabular}{|c|c|c|c|c|c|c|}
\hline $\begin{array}{l}\text { Member } \\
\text { Type }\end{array}$ & 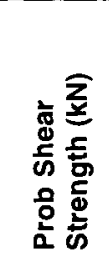 & 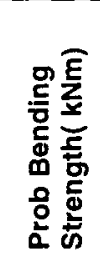 & 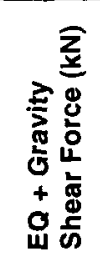 & 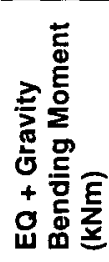 & 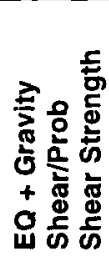 & 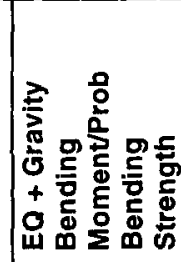 \\
\hline olur & $\overline{181}$ & 174 & 170 & 346 & 0.94 & 1.99 \\
\hline $\begin{array}{l}\text { Beam, } \\
\text { evel } 1\end{array}$ & 176 & 155 & 99 & 4 & 0.56 & 1.06 \\
\hline
\end{tabular}

Table 5-23-3 Summary of results of longitudinal wall for Villa d'Este building

\begin{tabular}{|c|c|c|c|c|c|c|c|c|c|}
\hline \multirow[b]{2}{*}{$\begin{array}{l}\text { Member } \\
\text { Type }\end{array}$} & \multirow[b]{2}{*}{ 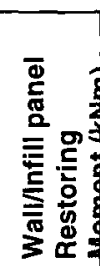 } & \multicolumn{4}{|c|}{ Strength of Infill Panels } & \multirow[b]{2}{*}{ 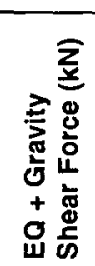 } & \multirow[b]{2}{*}{ 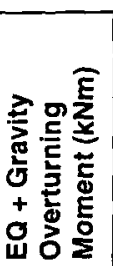 } & \multirow[b]{2}{*}{ 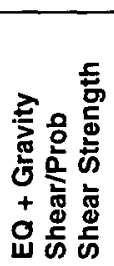 } & \multirow[b]{2}{*}{ 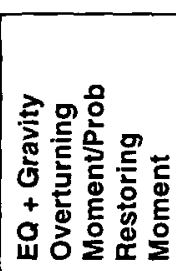 } \\
\hline & & 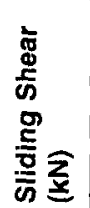 & 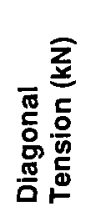 & 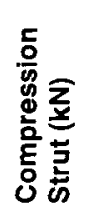 & 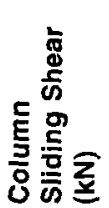 & & & & \\
\hline & 7095 & 930 & 1086 & 5394 & 2895 & 1870 & 820 & 2.01 & 1.16 \\
\hline
\end{tabular}

\section{Discussion}

Transverse: The results indicate the ground floor columns should have cracked due to yielding of reinforcing steel. Beams at Level 1 should have failed in bending. Though the "facade from level 1 to roof fell", there was little structural damage in this direction.

\section{Results Reliability Rating: C}

Longitudinal: The results suggest that sliding shear failure should have occurred in the infill panels. Recorded evidence of damage, "badly cracked", may refer to infill panels. The infill wall should have rocked though there are no recorded observations of this occurring.

\section{Results Reliability Rating: C}




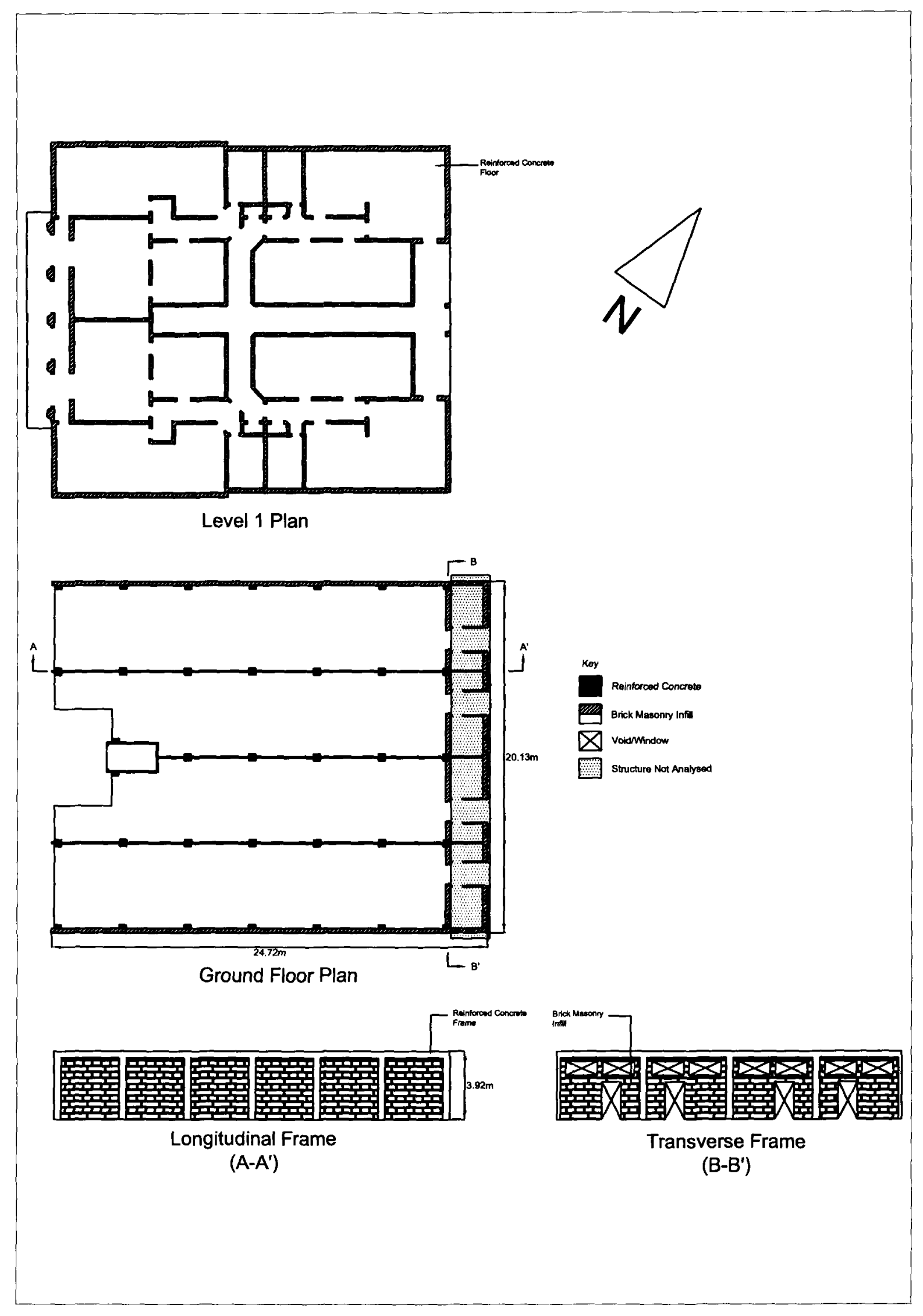




\section{Analysis of Results}

\section{Introduction}

This chapter examines and discusses the outcomes of the analyses in Chapter 5. Various structural systems are examined separately and results are compared to the "Code Load"10. The results are used in an attempt to determine why current theory expects the buildings in this study to fail seismically when damage records show that very little structural damage occurred.

\section{Structural Walls and Infill Walls}

\section{Overturning of Walls}

Figure 7 shows the cumulative frequency of the overturning to restoring moment ratios of all structural and infill walls using the estimated probable seismic load experienced during the Hawke's Bay earthquake. It clearly shows that just over 85 percent of all walls should have overturned or at least rocked. However, there are no records of damage related to rocking or overturning of walls.

Figure 8 displays the ratios when the Code Load is applied. Even though there is a reduction in the number of ratios greater than 1 , about 80 percent of all walls would still fail to meet code overturning requirements for seismic performance.

10 The Code Load referred to here is the seismic load determined using the New Zealand Loadings Standard, NZS4203: 1992. 


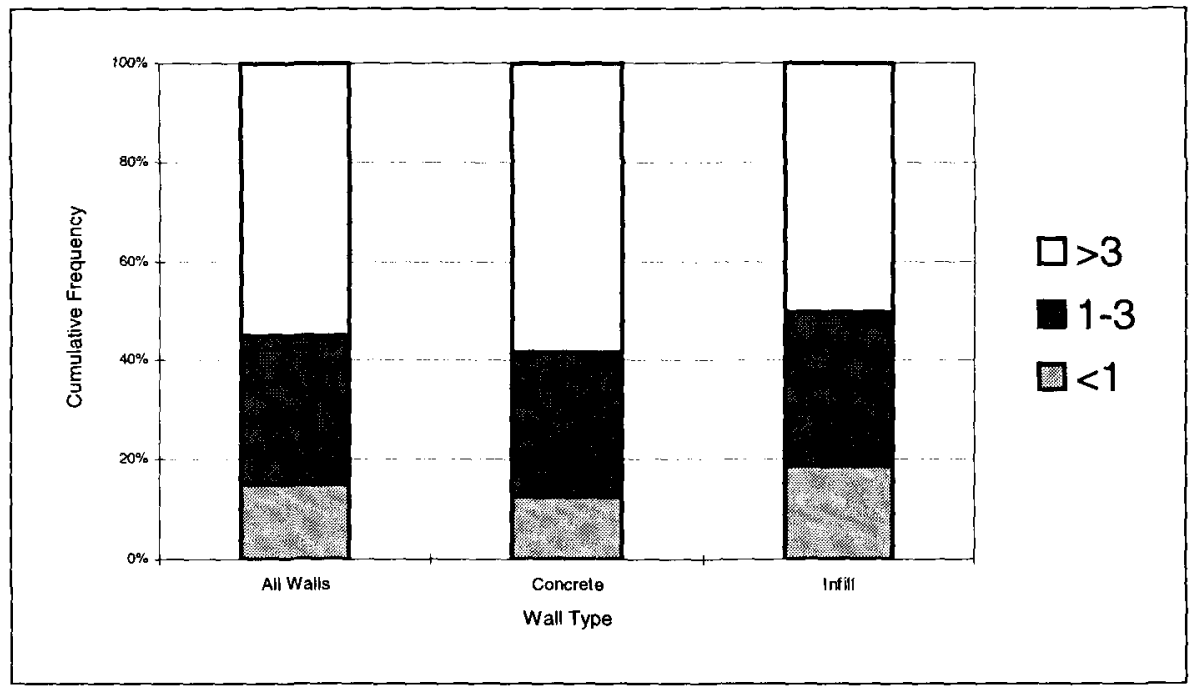

Figure 7 Cumulative Frequency Chart for Ratios of Overturning to Restoring Moment of Walls, for the Estimated Seismic Load

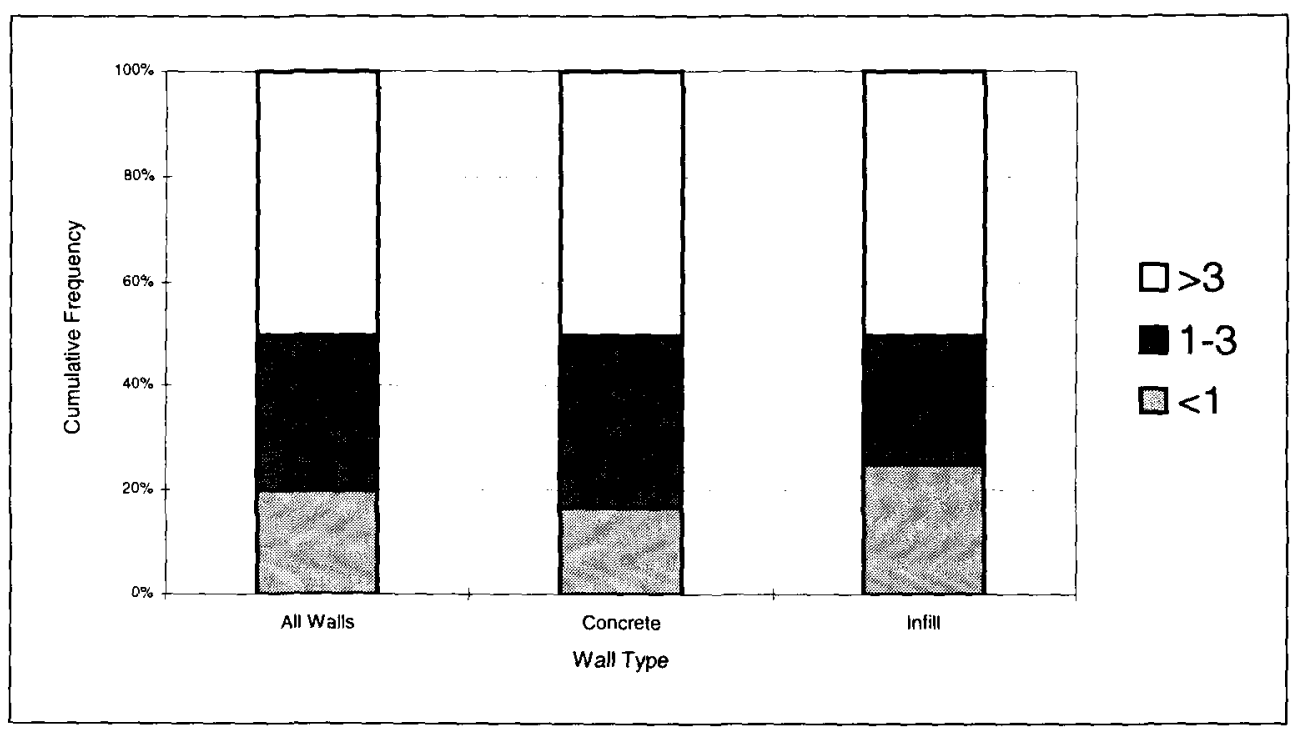

Figure 8 Cumulative Frequency Chart for Ratios of Overturning to Restoring Moment of Walls, for the Code Load

\section{Discussion}

The ratios used are for all walls regardless of RRR rating. The calculations used to determine overturning and restoring moments are reasonably independent of the criteria for RRR ratings. The calculated overturning ratios of walls for all buildings in this study indicate that most of the walls, either reinforced concrete structural walls or unreinforced brick masonry infill frame walls, should have overturned or at least rocked on their foundations. Though there were no observations of overturning or rocking occurring, nonetheless rocking could 
have occurred without causing significant structural damage. A lack of reported damage attributed to rocking suggests this is not an issue that requires detailed assessment.

Other studies of earthquake damage to similar walls (FEMA, 1997) indicate that overturning or rocking of walls may be acceptable: "Check that the calculated resistance (restoring moment) is greater than 0.75 times the base moment of the shear wall." That is, an overturning moment to restoring moment ratio of 1.33 or less is acceptable. The Green Book does not make mention of the restoring moment of walls, instead it concentrates on flexural capacity. Perhaps the Green Book acknowledges that rocking can be an acceptable postelastic mechanism, but it should explain and elaborate this issue.

The influence of several assumptions may affect the results. These assumptions have been necessary to simplify the analysis and narrow the research scope. Many of these assumptions are also common practice among structural design engineers. They are discussed below:

- It is assumed that the seismic force is based on a structural ductility factor of $\mu=1$. That is, all structures are assumed to have responded elastically, and at a short natural period of vibration, less than or equal to 0.42 seconds for Ground Class B and less than or equal to 0.6 seconds for Ground Class C. (Ground Class A is not discussed because there are no buildings located on it.) Some buildings may have responded with some ductility. In these cases the structural ductility factor, $\mu$, may be 1.25 or even 2 .

- In this study, with the exception of those buildings where URM walls are significant in number and configuration (Harston's Concert Hall, Methodist Church Hall), URM partition walls have been ignored in the distribution of seismic load. However, in some instances URM partition walls may have resisted a significant proportion of the seismic load, thus distorting the outcomes and decreasing the apparent restoring moment of a wall, and overestimating the ratios of overturning moment to restoring moment.

- Another major assumption is neglect of the influence of adjacent buildings (close enough to induce hammering), or adjoining buildings. The wall(s) of a building might have overturned in some instances if adjacent or adjoining buildings were not present. As most of the buildings in this study are located within the commercial centres of Hastings and Napier, many did have neighbouring buildings with which they either shared a common wall or were very close to the adjacent wall.

- The actual soil class could also influence the outcomes. As discussed in the Methodology, the soil conditions in Napier and Hastings are assumed to resemble the three soil 
classifications used in NZS4203: 1992. The soil conditions have been determined previously (Dowrick et al, 1995) and it is assumed that all buildings in Hastings are on a similar soil class. Variations in assumptions about soil classes within Hastings and within each Ground Class region in Napier would alter the results.

- Some buildings have infill walls at ground floor level and only URM partition walls on the upper floors. URM partition walls are accounted for in the seismic weight calculations but their seismic resistance has not been calculated. The Green Book does not mention how to analyse such structures.

- The effects of radiation damping are not addressed in this study. As Dowrick (1987) discusses, radiation damping of concrete footings is the energy loss from the structure through radiation of waves away from the footing. It is a purely geometrical effect. Radiation damping for concrete structures with large concrete foundation areas may result in a reduction in response by up to as much as 50 percent. Radiation damping, not allowed for in this study or in the Green Book, effectively reduces seismic response values of wall overturning moment, for stiff buildings on flexible soils, i.e., Ground Class C.

\section{Shear Strength of Walls}

Figure 9 and Figure 10 summarise the applied shear force to calculated shear strength ratios for structural and infill walls for buildings with an RRR rating of A or B. Values for seismic load and Code Load are presented separately.

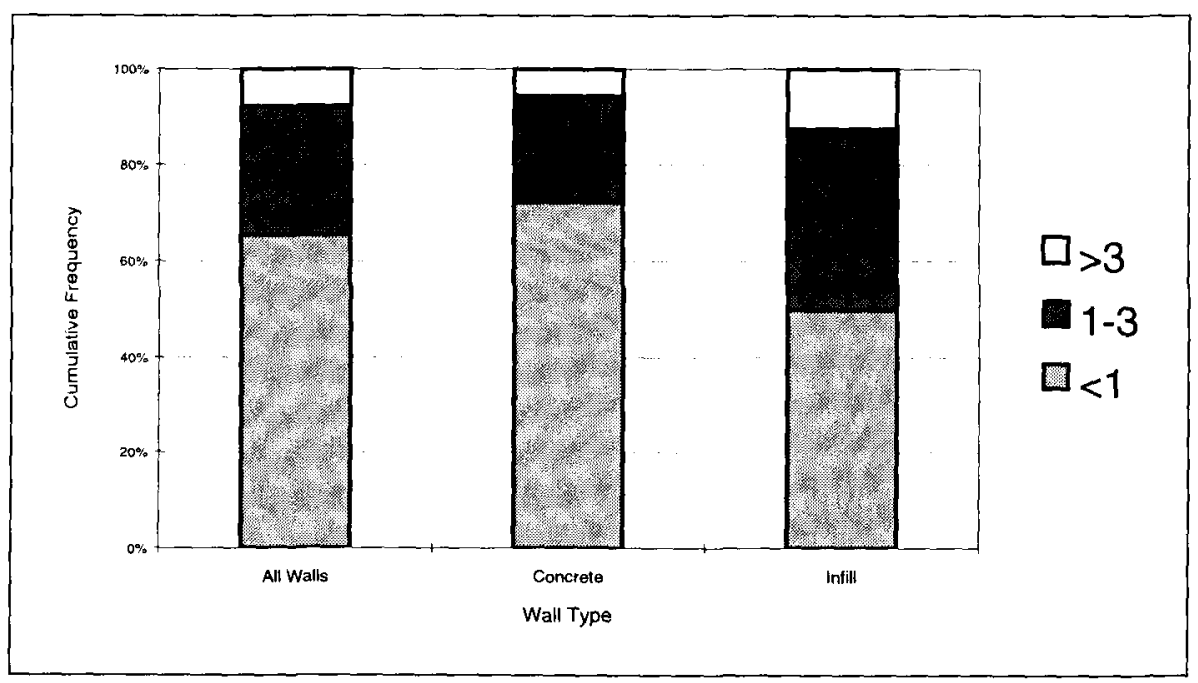

Figure 9 Cumulative Frequency Chart for Ratios of Applied Shear Force to Calculated Shear Strength of Walls, for the Estimated Seismic Load 


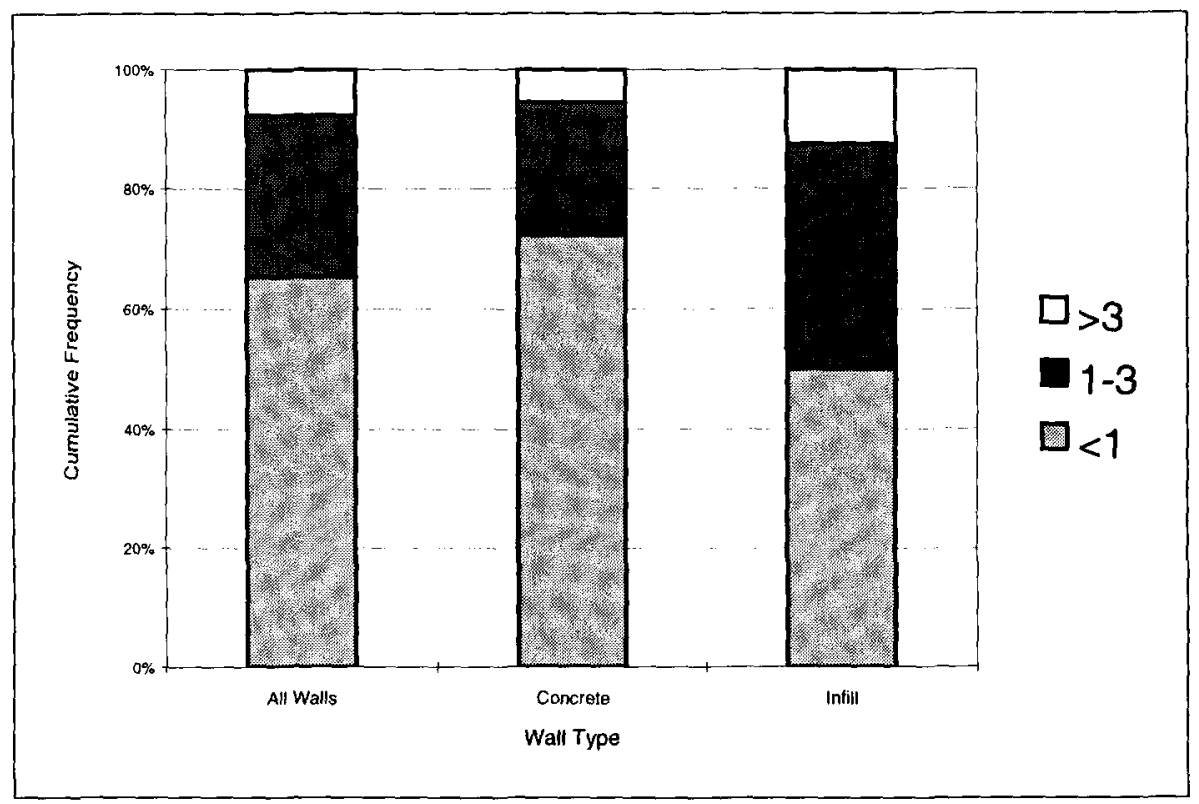

Figure 10 Cumulative Frequency Chart for Ratios of Applied Shear Force to Calculated Shear Strength of Walls, for the Code Load

\section{Discussion}

Figure 9 and Figure 10 suggest the following:

- No shear failure could be expected to occur in approximately 65 percent of these walls due to their sufficient shear strength.

- Where shear failure is expected to have occurred (in approximately 35 percent of walls), i.e. where a ratio of greater than unity is calculated, there was none reported.

- When the Code Load is applied to all walls, the number of ratios less than 1 does not change. Of all walled buildings, 70 percent are on Ground Class B and have a seismic load for the 1931 Hawke's Bay earthquake about 1.5 times that of the Code design earthquake load. Many walls of these buildings have a shear force to shear strength ratio much less than unity for the Code Load. When the ratios for the actual earthquake load are considered, these ratios are still less than unity.

Where ratios are greater than unity, theoretically walls should have failed in shear. The fact they did not fail, as the damage records show, can be attributed to several factors:

- The calculation of the seismic force has some uncertainties, as discussed for Overturning of Walls.

- Minor structural members, especially unreinforced masonry partition walls would reduce the actual forces in walls, reducing the ratio of shear force to shear strength. 
- Assumptions made about the reinforcing details and foundation details of walls introduce some uncertainties into the results. In many cases, construction details were unavailable and details from other buildings of the same construction period were used.

- The structural action of the wall could also impact on the results. Many of the walls that should have failed in shear may have rocked on their foundations first, reducing shear demand. This is explored in greater detail in the following section.

\section{Rocking of Walls as a Mechanism to Prevent Shear Failure}

Figure 11 shows overturning moment ratios divided by shear ratios. For all buildings, regardless of structural type, the overturning moment ratio is greater than the shear ratio. This suggests that where shear failure is expected to have occurred, but did not, it may have been prevented by rocking of walls. The damage records support this view as only two buildings experienced wall shear failure.

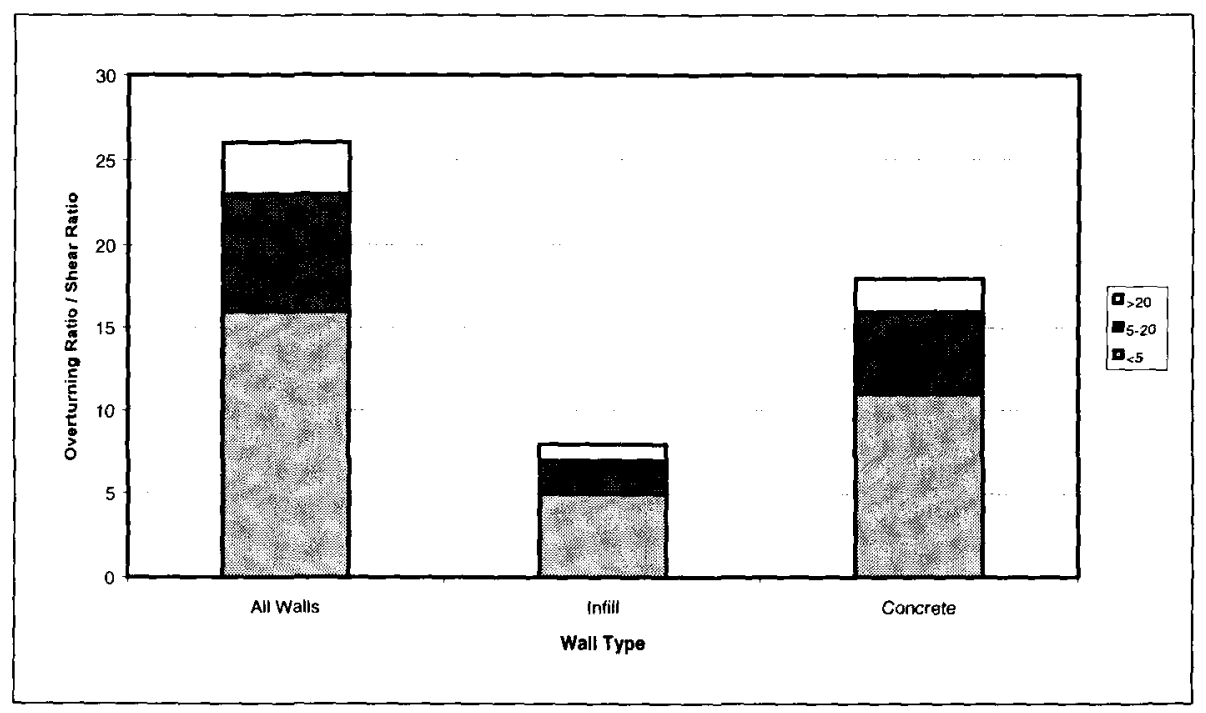

Figure 11 Overturning Ratios / Shear Ratios for Walls, for the Estimated Seismic Load

\section{Infill Panel Shear Strength}

Infill panels exhibit three possible failure modes: sliding shear failure of the infill panel(s), diagonal tension/compression strut failure of the infill panel(s) or sliding shear failure of the adjacent column-top(s). 


\section{Discussion}

Figure 9 and Figure 10 suggest the following:

- Approximately 50 percent of infill frames should have failed in shear but damage records suggest only about 25 percent should have failed in the 1931 Hawke's Bay earthquake.

- When the Code Load is applied as the lateral load to walls, the number of infill walls expected to have sufficient strength, i.e., have a shear force to strength ratio equal to or less than unity does not change. This is primarily due to many of the ratios being much less than unity, so when a higher seismic load is experienced, they are still less than unity.

The results discussed above are influenced by several assumptions:

- Rocking of walls may have preceded, and thus prevented, shear failure of infill panel of infill walls;

- Interaction of infill panels with the adjoining columns may have reduced shear stress on infill panels. There is no separation of panel and columns;

- URM partition walls, as discussed for Overturning of Walls and Shear Strength of Walls, are not accounted for and may lead to slightly higher ratios in some instances;

- Neighbouring buildings, as discussed for Overturning of Walls and Shear Strength of Walls, are not accounted for and may also affect the results.

Results also show that for all infill walls with an RRR rating of $A$ or $B^{11}$, where failure should have occurred, five walls should have failed in sliding shear of the infill panel and three should have failed in diagonal tension (see Table 6-1). Sliding shear of the adjacent column top is not critical and perhaps the Green Book is not correct in not considering this failure mode. However, a lack of data (only eight walls are used) makes this finding an indicator for further research at best.

Table 6-1 Frequency of failure modes for URM infill panel(s)

\begin{tabular}{|l|l|l|}
\hline \multicolumn{1}{|c|}{ Failure Mode } & $\begin{array}{l}\text { No. that should } \\
\text { have failed }\end{array}$ & $\begin{array}{c}\text { Total No. of walls } \\
\text { susceptible to a } \\
\text { given failure mode* }\end{array}$ \\
\hline Sliding shear of infill panel(s) & 3 & 5 \\
\hline Diagonal tension/Compression strut & 1 & 3 \\
\hline Sliding shear of adjacent column-top & 0 & 0 \\
\hline
\end{tabular}

* If seismic loading is sufficient to induce failure, these figures represent the number of infill panel(s) that would fail for each failure mode.

11 Infill walls with an RRR rating of $\mathrm{C}$ are not used, as the results are not reliable. 


\section{Moment Resisting Frames}

\section{Shear and Bending Strength}

Figure 12 and Figure 13 summarise ratios of actual shear force to probable shear strength, and actual bending moment to probable bending strength for columns at ground floor level and beams at Level 1 in open moment resisting frames in buildings with a Results Reliability Rating (RRR) rating of $\mathrm{A}$ or $\mathrm{B}$.

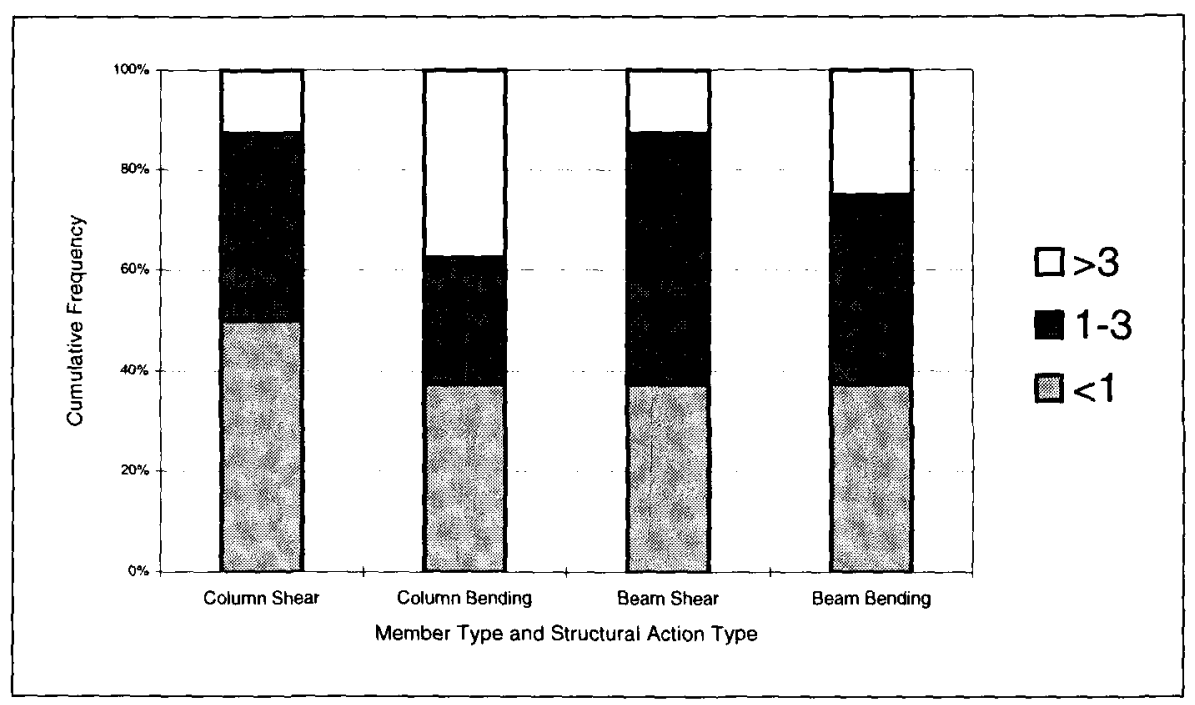

Figure 12 Cumulative frequency chart for Ratios of Applied Shear Force to Calculated Shear Strength and Applied Bending Moment to Calculated Bending Strength of Moment Resisting Frames, for the Estimated Seismic Load

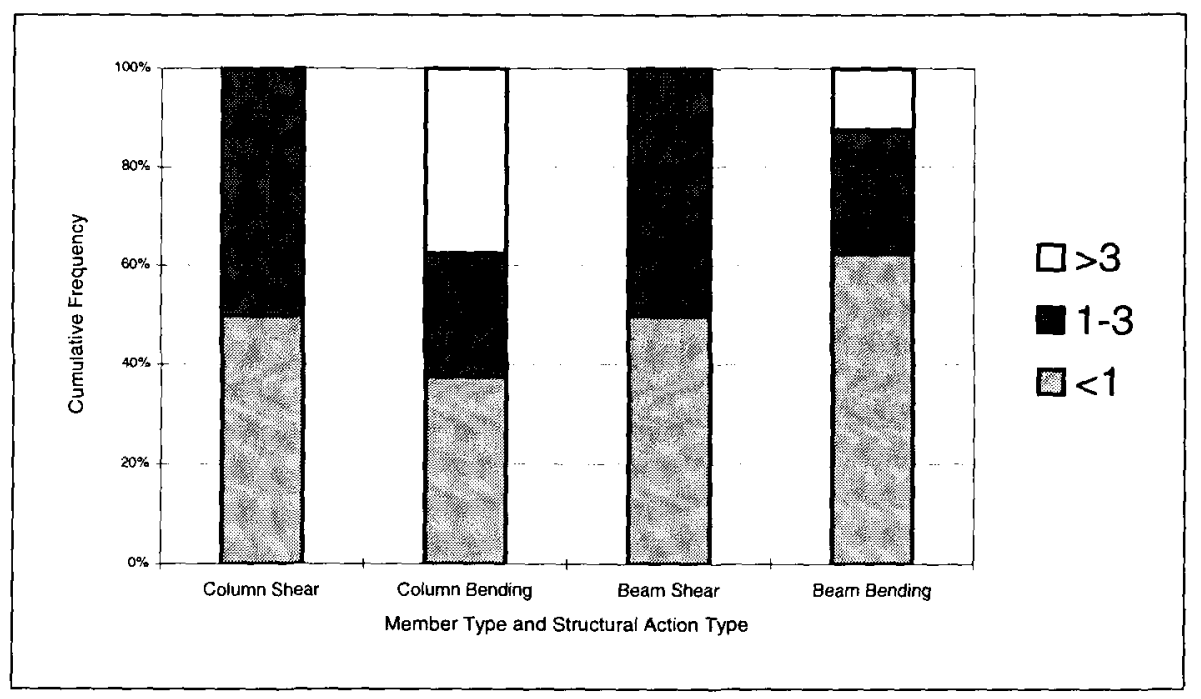

Figure 13 Cumulative frequency chart for Ratios of Applied Shear Force to Calculated Shear Strength and Applied Bending Moment to Calculated Bending Strength of Moment Resisting Frames, for the Code Load 


\section{Discussion}

The ratios presented in Figure 12 and Figure 13 suggest the following:

- Approximately 50 percent of columns were calculated as having their shear strength exceeded, but damage records show no shear failure of any ground floor columns.

- Approximately 63 percent of columns do not satisfy code requirements for bending. No columns were reported failing in this way, even though the Code Load is less than the estimated probable seismic load.

- The beam shear and bending ratios suggest approximately 60 percent should have failed. There are few damage records that suggest failure of beams in either shear or bending.

The results for moment resisting frames are influenced by several uncertainties:

- Moment resisting frames, in some cases, resist seismic load as part of a hybrid system. The other part of the hybrid system is generally URM partition walls. As discussed for structural and infill walls, the Green Book does not take the influence of these URM walls into account and so frame performance is likely to be better than calculations indicate. Some frames have infill panels that are highly penetrated. This study excludes them, and hence the ratios for some frames should be lower.

- The influence of neighbouring buildings, as discussed for structural and infill walls, has not been taken into account. Doing so complicates the analysis beyond the scope of this study. Where buildings with moment resisting frames adjoin another building(s) or are close enough to be influenced by hammering, the ratios of these frames could vary depending on the resistance offered by neighbouring buildings. The Green Book does not take this into account. This influence is of particular importance to frames in the transverse direction as most street facades are moment resisting frames.

- Reinforcing details of most frames studied have been derived from other buildings of the same construction period. It is possible that some reinforcing details assumed for these frames are not correct. Ratios for such frames will vary accordingly.

- The assumption of fixed column-bases will tend to increase the column shear ratios and reduce column and beam bending ratios.

- Other uncertainties as previously discussed for structural and infill walls, will also influence the results. 


\section{Approximate Assessment Procedure}

Phase 5 of the Methodology describes an attempted simplified building assessment method based on the vertical reinforced concrete structure calculated as a percentage of the gross ground floor area. In order to determine the minimum structure required, data from damaged buildings is needed. Since there are only two buildings in this study that suffered significant structural damage, the minimum percentage of structure cannot be accurately determined for all structural types.

All the buildings in this study survived the 1931 Hawke's Bay earthquake and most did not suffer structural damage. Figure 14 is based on the structural footprints for the three structural systems analysed in this study. Footprint areas of reinforced concrete members only, expressed as a percentage of gross ground floor area, are calculated for each orthogonal direction separately.

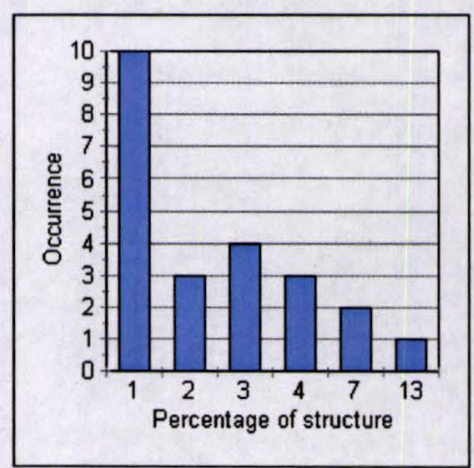

Walls

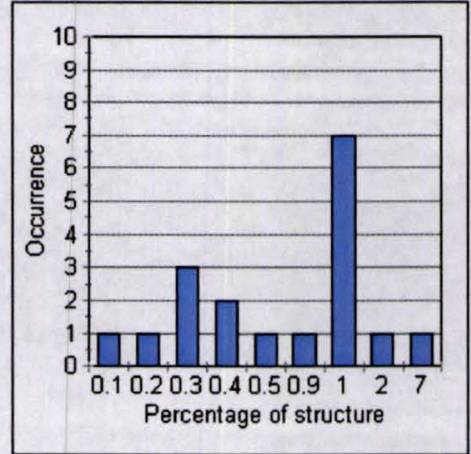

Infill Frames

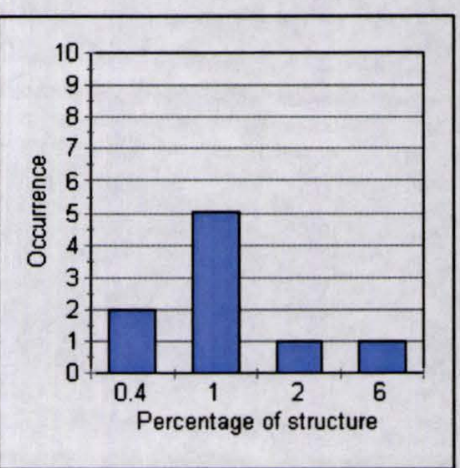

Open Frames

Figure 14 Occurrences of Different Structural Footprints for Infill Frames, Open Frames and Walls

Based on Figure 14, Table 6-2 presents the minimum structural footprints for each orthogonal direction, of undamaged reinforced concrete buildings that survived an earthquake with a load between 1.07 and 1.56 of the Code Load. 
Table 6-2 Minimum Structural Footprints and Fraction of Code Load resisted by Structural Systems for given Ground Classes for undamaged buildings.

\begin{tabular}{|l|c|c|c|}
\hline \multicolumn{1}{|c|}{ Structural System } & $\begin{array}{c}\text { Ground } \\
\text { Class }\end{array}$ & $\begin{array}{c}\text { Structural } \\
\text { Footprint (\%) }\end{array}$ & $\begin{array}{c}\text { Fraction of Code Load } \\
\text { resisted by system }\end{array}$ \\
\hline Reinforced Concrete & Napier, B & 1 & 1.56 \\
Wall & Napier, C & 1 & 1.14 \\
& Hastings, C & 1 & 1.07 \\
\hline \multirow{3}{*}{ Infill Frame Wall } & Napier, B & $0.3(1)$ & 1.56 \\
& Napier, C & $0.3(1)$ & 1.14 \\
& Hastings, C & $0.3(1)$ & 1.07 \\
\hline \multirow{2}{*}{ Open Moment } & Napier, B & 0.4 & 1.56 \\
Resisting Frame & Napier, C & 0.4 & 1.14 \\
& Hastings, C & 0.4 & 1.07 \\
\hline
\end{tabular}

The results in Table 6-2 suggest the following:

- Open moment resisting frames with a structural footprint of at least 0.4 percent in each orthogonal direction, and on a site similar to Ground Class B, are expected not to fail during an earthquake equal to or less than one and a half times as much as the Code design earthquake load. Buildings on a site similar to Ground Class $\mathrm{C}$ should not suffer damage in an earthquake equal to or less than 1.14 times the Code Load.

- For infill frame structures a minimum structural reinforced concrete footprint of 0.3 percent is required to resist an earthquake equal to or less than one and a half times the Code Load. This figure is derived using the reinforced concrete structural footprint only. The minimum structural footprint for infill frames that include brick infill panels is 1 percent for all Ground Classes (as indicated by the bracketed figures in Table 6-2).

- Reinforced concrete walled structures require a structural footprint of at least 1 percent to resist an earthquake equal to or less than one and a half times the Code Load. Glogau (1980) states that a minimum structural footprint should be $0.3 \mathrm{n}$ percent, where $\mathrm{n}$ is the number of stories above the level being considered (but not less than 2), which equates to 0.6 and 0.9 percent for two and three-storied structures. Comparing these figures with the minimum structural footprints for the walled structures in this study shows that a structural footprint of 1 percent may be slightly conservative. 


\section{Conclusions and Recommendations}

\section{Introduction}

This chapter summarises the findings presented in the previous chapter. Each structural system is summarised individually and a global commentary on the Green Book and recommendations concerning further research follow.

\section{Damage to Buildings}

Of all reinforced concrete buildings in this study while 28 percent suffered damage to brickwork as a result of the 1931 Hawke's Bay earthquake only 12 percent suffered damage to reinforced concrete structure. The results of this study show that significant numbers of structures should have failed under the earthquake load calculated according to the Green Book approach. Many buildings fail to meet current code requirements for seismic performance, yet almost all survived an earthquake that, for Ground Class B, was likely to have been about 1.5 times the design earthquake.

The above finding suggests current Building Code requirements for reinforced concrete 'Earthquake Risk Buildings' may be too stringent on seismic performance. Perhaps there can be a relaxation of Code or Green Book requirements for buildings with similar construction details and on similar sites. This can potentially save many building owners unnecessary expenditure on upgrading and strengthening.

\section{Reinforced Concrete Structural Walls}

For most structural walls analysed in this study the main points to note are:

- The calculations implied that most walls should have rocked on their foundations but there was no evidence of this happening. This may be due to the following:

- Effect of neighbouring buildings;

- Presence of minor structural members such as URM partition walls;

- Effects of radiation damping.

These effects are not discussed in the Green Book. 
- Some walls should have failed through a lack of shear strength but did not. This could be due to rocking walls reducing seismic load thus reducing induced shear, or due to certain uncertainties such as:

- A greater influence of URM partition walls on the seismic response than this study allows for, not accounted for in the Green Book;

- Assumptions made about reinforcing details.

\section{URM Infill Frame Walls}

The main findings for this structural type are:

- The calculations implied that many infill walls should have rocked on their foundations but there is no recorded evidence of damage that can be attributed to overturning effects. The explanations are already discussed for Reinforced Concrete Structural Walls.

- The calculations implied that most infill panels should have failed through sliding shear but did not. This may be due to rocking of the wall occurring first and hence lessening the seismic response and shear force to be resisted. There are no cases where the column-top adjacent to the infill panel should have failed in sliding shear or was reported as having failed.

\section{Moment Resisting Frames}

The analysis of results for this structural system are summarised below:

- Columns and beams, at ground floor and Level 1 respectively, were estimated to have failed in bending and shear in many cases but did not;

- The influence of hybrid systems (moment resisting frames with minor URM infill partition walls), not taken into account in this study, may have reduced the seismic actions on moment resisting frames;

- The assumption of $\mu=1$, i.e. all buildings are assumed to respond elastically, does affect the results, as seismic load is very sensitive to the value of $\mu$. This has been discussed for Overturning of Walls.

\section{Approximate Assessment Procedure}

The assessment method described in Phase 5 of the Methodology cannot be completed, as most of the buildings used in this study did not suffer significant structural damage. Therefore the minimum vertical structure required to avoid future structural damage for 
reinforced concrete structural walled and open framed structures cannot be determined.

Since most of the buildings in this study were not damaged, the lowest common value of structural footprint (area of structure/gross ground floor area) below may be considered adequate to resist full Code Loads:

\author{
Structural System Area of footprint in each orthogonal direction (\%) \\ Structural Wall $\quad 1$ \\ Infill Frame $\quad 0.3 / 1^{*}$ \\ Open Frame $\quad 0.4$ \\ * 0.3 percent applies to reinforced concrete structure only; 1 percent applies to structure including unreinforced \\ brick masonry infill panels.
}

These values can be used to assess other buildings of similar construction on similar soil sites, i.e., any building that has at least the minimum structural footprint area in each direction on soil classes similar to one of the three used in this study should not suffer serious structural damage during an earthquake equal to or less than approximately one and a half times the design Code Load.

\title{
Recommendations
}

The Green Book is now four years old and still a draft document albeit under continual review (Brunsdon, 1999). The findings from this research, if implemented, are expected to improve the Rapid Assessment Procedure of the Green Book.

Further research into the relationship between the rocking and shear strength of reinforced concrete structural walls and URM infill frame walls is required to determine how much wall rocking lessens the shear stress on that wall. This will enable strengthening requirements for walled buildings to be refined.

Further research is required to determine the minimum structural footprint capable of resisting seismic loads at the Code Load level. This will entail collection of data of damaged buildings from other earthquakes and subsequent integration of it with the data from this study. 


\section{Appendix A}

\section{Response Spectra of Ground Classes A, B, and C}

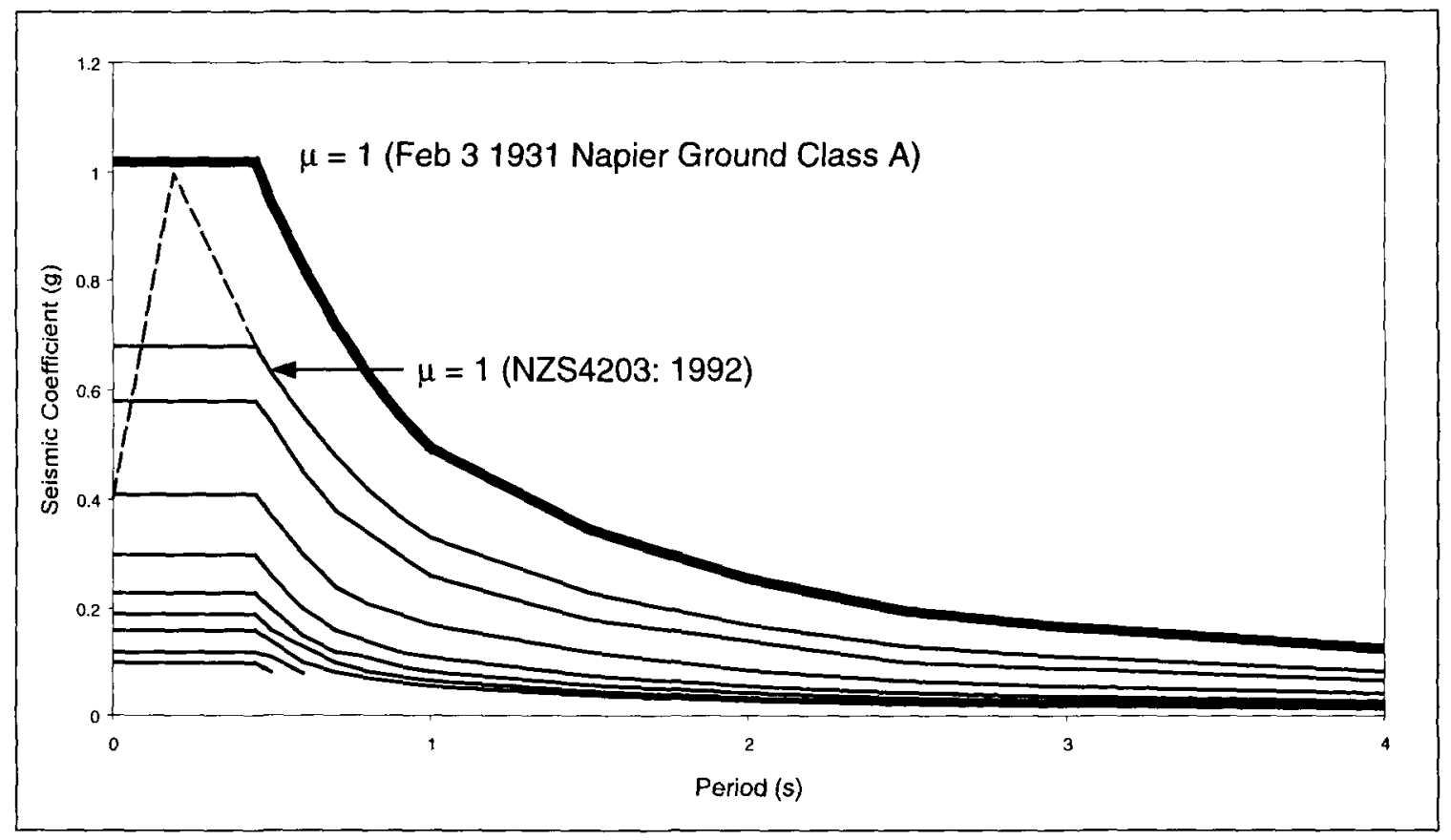

Figure 15 Response Spectrum of February 31931 Earthquake, Napier, Ground Class A (after McVerry et al, 2000)

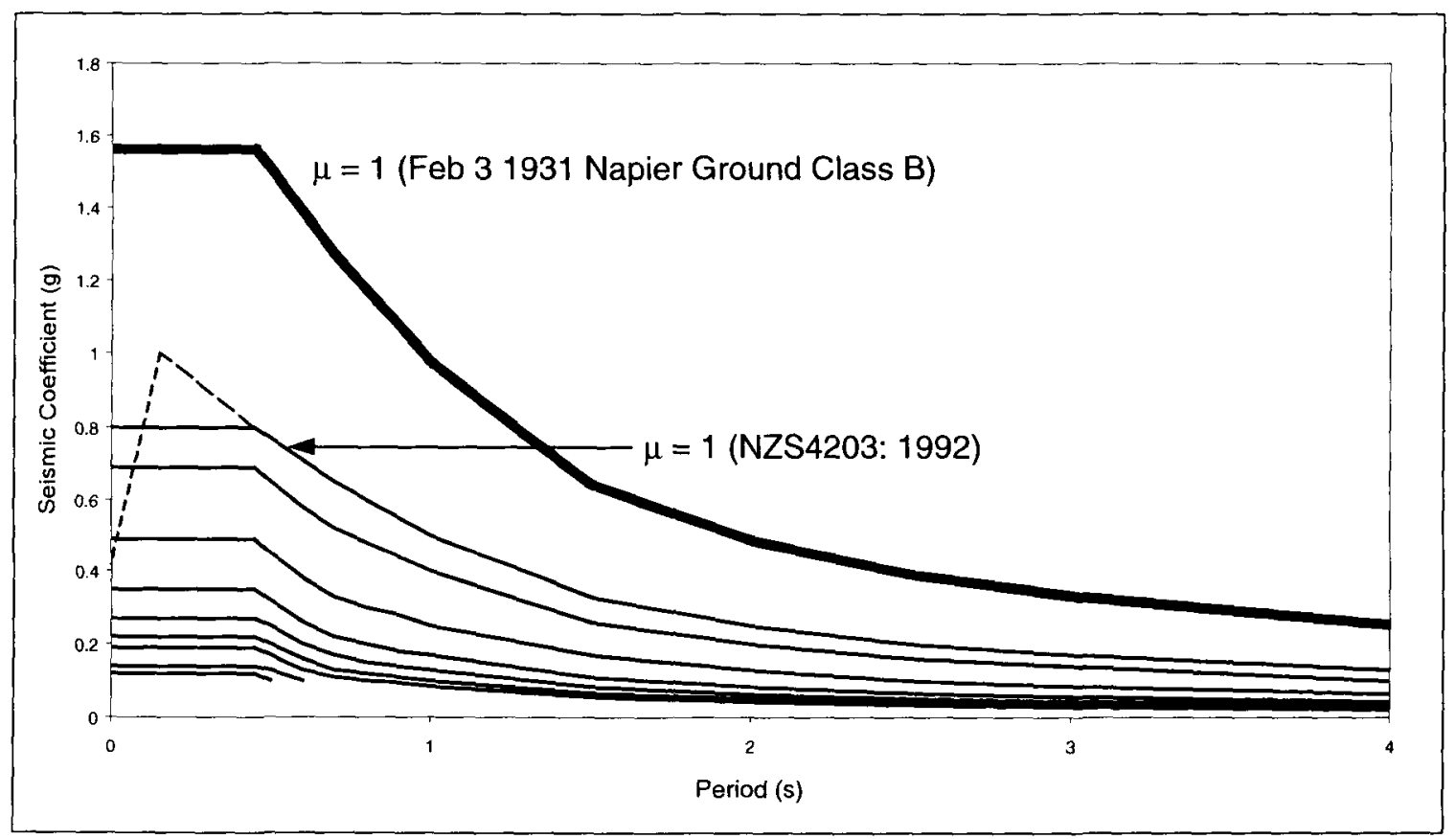

Figure 16 Response Spectrum of February 31931 Earthquake, Napier, Ground Class B (after McVerry et al, 2000) 


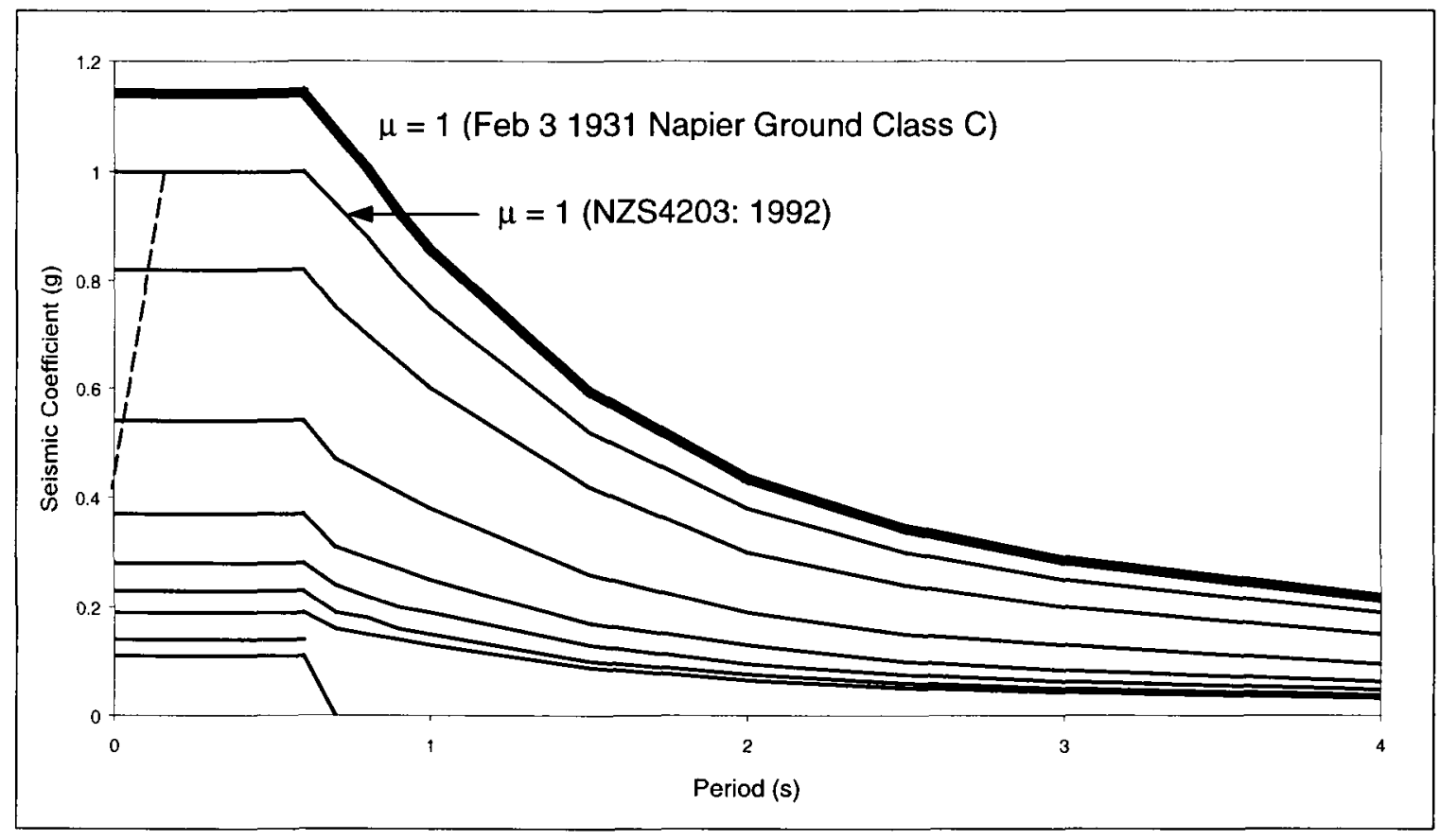

Figure 17 Response Spectrum of February 31931 Earthquake, Napier, Ground Class C (after McVerry et al, 2000)

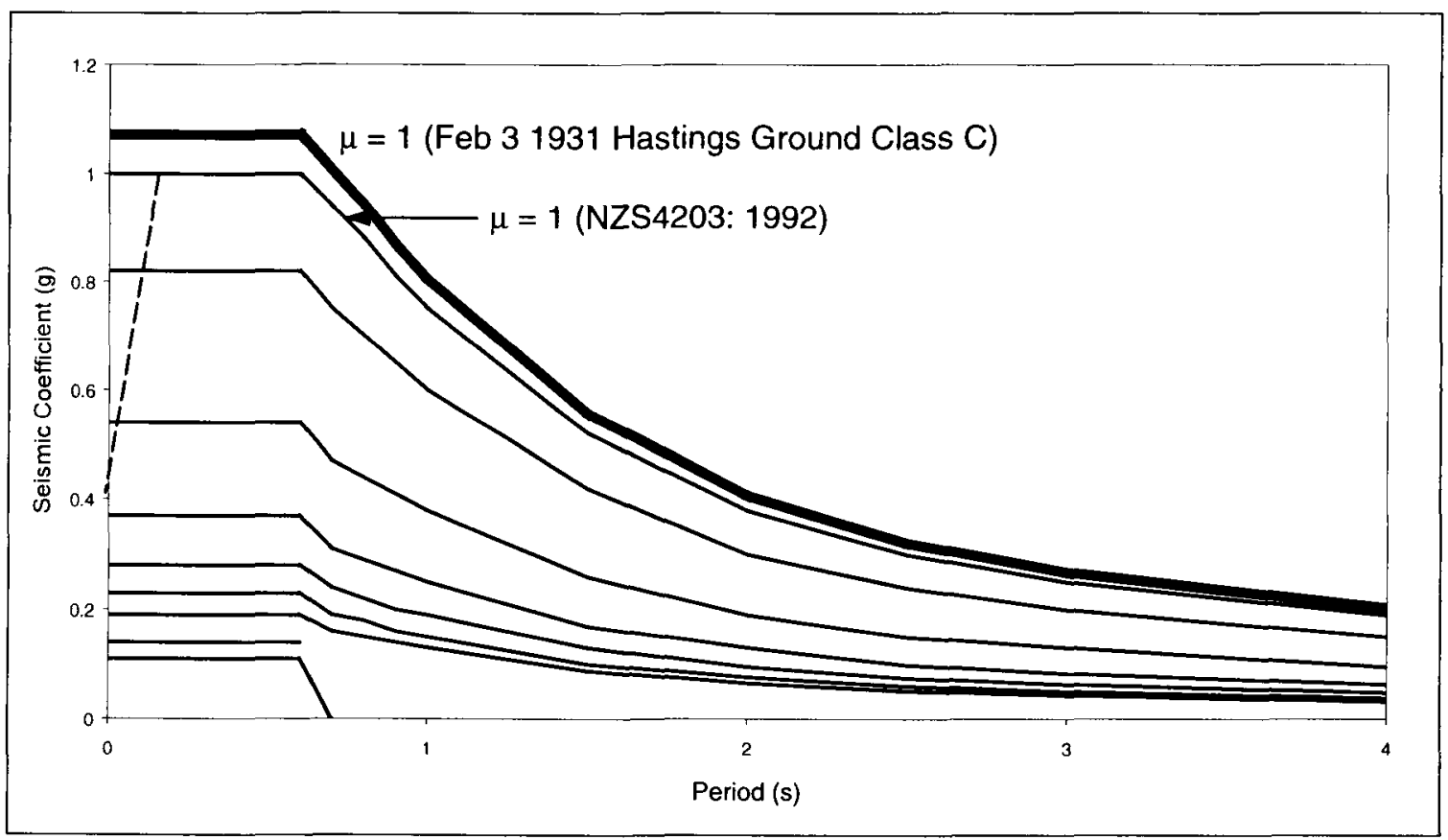

Figure 18 Response Spectrum of February 31931 Earthquake, Hastings, Ground Class C (after McVerry et al, 2000) 
NAPIER

Methodist Church Hall

Gilberd \& Co

Hawke's Bay County Council

Public Trust Office (N)

Murdoch J H, Bakery

Dalgety \& Co

Ancient Order of Foresters

Ringland Bros.

Union Hotel

Harston's Concert Hall

Bennett Building

Parker Chambers

Williams Buildings (I)

Williams Buildings (II)

Richardson \& Co. Ltd.

Howe Bros.

West (JS) \& Co

HASTINGS

Poppelwells

Dominion Buildings

Public Trust Office (H)

Rainbow, Hobbs \& Nesbitt

H.B. Jockey Club's Racecourse

Hawke's Bay Farmer's Co-Op

Webber's Buildings

Villa d'Este

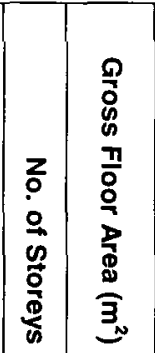

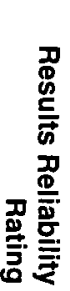
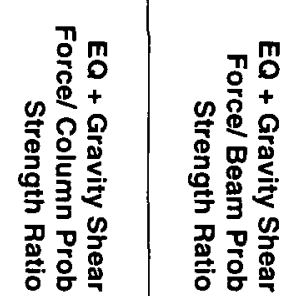

\begin{tabular}{|c|c|c|c|c|c|c|c|c|c|c|c|c|c|c|c|c|c|}
\hline 2 & 276 & A & B & 1.31 & 0.76 & 0.34 & 0.43 & 0.92 & 0.34 & 0.44 & 0.32 & 0.96 & 0.28 & 20.44 & 4.98 & 1 & 2 \\
\hline
\end{tabular}

\begin{tabular}{|c|c|c|c|c|c|c|c|c|c|c|c|c|c|c|c|c|c|}
\hline $2+B$ & 277 & B & B & N/A & N/A & N/A & N/A & N/A & N/A & N/A & N/A & 2.58 & 0.70 & 24.00 & 3.18 & 1 & 5 \\
\hline
\end{tabular}

\begin{tabular}{|c|c|c|c|c|c|c|c|c|c|c|c|c|c|c|c|c|c|}
2 & 502 & B & B & N/A & N/A & N/A & N/A & N/A & N/A & N/A & N/A & 1.90 & 1.66 & 4.41 & 2.88 & 1 & 1 \\
\hline
\end{tabular}

(1)

\begin{tabular}{|c|c|c|c|c|c|c|c|c|c|c|c|c|c|c|c|c|c|}
2 & 456 & B & B & 1.66 & N/A & 2.70 & N/A & 5.52 & N/A & 2.75 & N/A & N/A & 0.71 & N/A & 2.55 & 1 & 1 \\
\hline
\end{tabular}

\begin{tabular}{|c|c|c|c|c|c|c|c|c|c|c|c|c|c|c|c|c|c|c|}
\hline 2 & 599 & B & B & N/A & N/A & N/A & N/A & N/A & N/A & N/A & N/A & 0.14 & 0.39 & 2.43 & 20.83 & 4 & 4 \\
\hline
\end{tabular}

\begin{tabular}{|c|c|c|c|c|c|c|c|c|c|c|c|c|c|c|c|c|c|}
2 & 183 & $B$ & $B$ & 0.26 & N/A & 1.15 & N/A & 0.85 & N/A & 1.20 & N/A & 2.97 & 0.69 & 23.24 & 3.23 & 0.3 & 2 \\
\hline
\end{tabular}

\begin{tabular}{|c|c|c|c|c|c|c|c|c|c|c|c|c|c|c|c|c|c|c|}
2 & 453 & B & B & N/A & N/A & N/A & N/A & N/A & N/A & N/A & N/A & 2.01 & 2.85 & 5.11 & 23.25 & 0.4 & 0.3 \\
\hline
\end{tabular}

\begin{tabular}{|c|c|c|c|c|c|c|c|c|c|c|c|c|c|c|c|c|c|c|}
\hline 2 & 464 & B & B & 2.79 & N/A & 3.53 & N/A & 9.41 & N/A & 7.14 & N/A & N/A & 0.70 & N/A & 1.32 & 0.4 & 0.4 \\
\hline
\end{tabular}

\begin{tabular}{|c|c|c|c|c|c|c|c|c|c|c|c|c|c|c|c|c|c|}
\hline $3+B$ & 265 & $B$ & $B$ & 3.42 & N/A & 1.87 & N/A & 11.27 & N/A & 1.19 & N/A & N/A & 0.35 & N/A & 1.08 & 1 & 3 \\
\hline
\end{tabular}

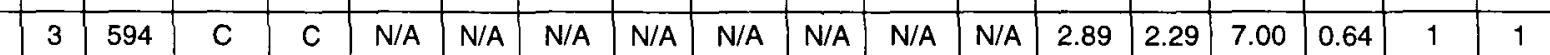

\begin{tabular}{|c|c|c|c|c|c|c|c|c|c|c|c|c|c|c|c|c|c|}
2 & 386 & C & C & N/A & 8.54 & N/A & 2.51 & N/A & 4.16 & N/A & 2.29 & 0.35 & N/A & 6.61 & N/A & 12 & 4 \\
\hline
\end{tabular}

\begin{tabular}{|c|c|c|c|c|c|c|c|c|c|c|c|c|c|c|c|c|c|}
2 & 195 & C & C & N/A & 3.05 & N/A & 3.98 & N/A & 6.55 & N/A & 4.96 & 1.18 & N/A & 2.93 & N/A & 1 & 1 \\
\hline
\end{tabular} \begin{tabular}{|c|c|c|c|c|c|c|c|c|c|c|c|c|c|c|c|c|c|}
2 & 465 & $\mathrm{C}$ & $\mathrm{C}$ & 2.07 & $\mathrm{~N} / \mathrm{A}$ & 0.94 & $\mathrm{~N} / \mathrm{A}$ & 3.33 & $\mathrm{~N} / \mathrm{A}$ & 0.96 & $\mathrm{~N} / \mathrm{A}$ & 0.72 & 0.50 & 2.27 & 1.50 & 1 & 3 \\
\hline
\end{tabular}

\begin{tabular}{|c|c|c|c|c|c|c|c|c|c|c|c|c|c|c|c|c|c|}
2 & 172 & C & C & 1.79 & N/A & 2.95 & N/A & 5.17 & N/A & 7.84 & N/A & N/A & 1.64 & N/A & 1.69 & 2 & 1 \\
\hline
\end{tabular}
\begin{tabular}{|c|c|c|c|c|c|c|c|c|c|c|c|c|c|c|c|c|c|}
\hline 2 & 257 & C & C & 3.26 & N/A & 1.68 & N/A & 8.11 & N/A & 2.22 & N/A & N/A & 0.33 & N/A & 0.92 & 1 & 3 \\
\hline
\end{tabular} (1)

\begin{tabular}{|c|c|c|c|c|c|c|c|c|c|c|c|c|c|c|c|c|c|}
\hline 2 & 368 & B & B & N/A & 0.90 & N/A & 0.93 & N/A & 1.43 & N/A & 0.74 & 0.64 & N/A & 1.79 & N/A & 1 & 1 \\
\hline
\end{tabular}

\begin{tabular}{|l|l|l|l|l|l|l|l|l|l|l|l|l|l|l|l|l|l|}
\hline 2 & 416 & B & B & N/A & N/A & N/A & N/A & N/A & N/A & N/A & N/A & 4.47 & 0.31 & 14.89 & 0.71 & 7 & 2 \\
\hline
\end{tabular}

\begin{tabular}{|l|l|l|l|l|l|l|l|l|l|l|l|l|l|l|l|l|l|}
2 & 514 & B & B & N/A & N/A & N/A & N/A & N/A & N/A & N/A & N/A & 1.99 & 0.77 & 3.26 & 1.14 & 1 & 2 \\
\hline
\end{tabular}

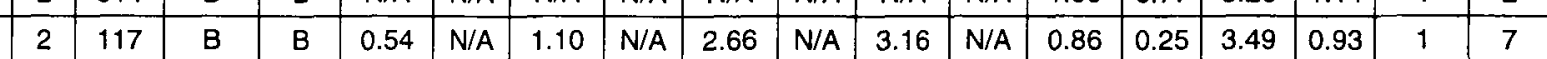

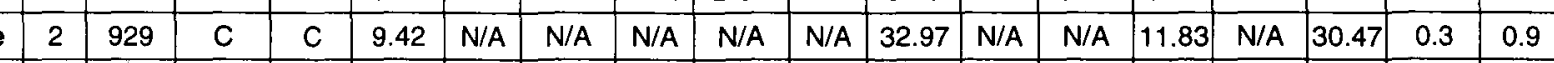

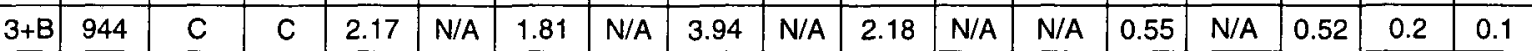

\begin{tabular}{|l|l|l|l|l|l|l|l|l|l|l|l|l|l|l|l|l|l|}
\hline & 234 & C & C & N/A & N/A & N/A & N/A & N/A & N/A & N/A & N/A & 0.94 & 4.37 & 6.41 & 3.40 & 1 & 0.5 \\
\hline
\end{tabular}




\section{Appendix C}

\section{Summary Table of Damage and Vertical Reinforced Concrete Structure}

\begin{tabular}{|c|c|c|c|}
\hline \multirow[b]{2}{*}{ NAPIER } & \multicolumn{2}{|c|}{$\begin{array}{c}\% \text { Reinforced Concrete } \\
\text { of Gross Floor Area }\end{array}$} & \multirow[b]{2}{*}{ Records of damage } \\
\hline & Trans & Long & \\
\hline Methodist Church Hall & 1 & 0.4 & End walls (brick) unsafe. \\
\hline Gilberd \& Co & 1 & 2 & No structural damage. \\
\hline Hawke's Bay County Council & 1 & 1 & 2 parapets down. \\
\hline Public Trust Office (N) & 1 & 1 & $\begin{array}{l}\text { Badly cracked and unsafe. Large shear cracks in structural walls. } \\
\text { Roof beams damaged. }\end{array}$ \\
\hline Murdoch J H, Bakery & 3 & 4 & Floor and wall cracked. \\
\hline Dalgety \& Co & 1 & 1 & No structural damage. \\
\hline Ancient Order of Foresters & 4 & 4 & No structural damage. \\
\hline Ringland Bros. & 0.3 & 2 & Brick badly cracked. \\
\hline Union Hotel & 0.4 & 0.3 & No structural damage. \\
\hline Harston's Concert Hall & 0.4 & 0.4 & No structural damage. \\
\hline Bennett Building & 1 & 3 & No structural damage. \\
\hline Parker Chambers & 1 & 7 & Brick walls on $4^{\text {th }}$ floor fell. \\
\hline Williams Buildings (I) & 13 & 6 & Slight. \\
\hline Williams Buildings (II) & 1 & 1 & End gable fell out. \\
\hline Richardson \& Co. Ltd. & 1 & 3 & Slightly damaged. \\
\hline Howe Bros. & 2 & 1 & Tile roof and 2 large chimneys down. Brickwork off sidewalls. \\
\hline West (JS) \& Co & 1 & 3 & Sidewalls damaged at $1^{\text {st }}$ floor. \\
\hline \multicolumn{4}{|l|}{ HASTINGS } \\
\hline Poppelwells & 1 & 1 & End gable fell out. \\
\hline Dominion Buildings & 7 & 2 & No structural damage. \\
\hline Public Trust Office (H) & 1 & 2 & No structural damage. \\
\hline Rainbow, Hobbs \& Nesbitt & 1 & 7 & No structural damage. \\
\hline H.B. Jockey Club's Racecourse & 0.3 & 0.9 & $\begin{array}{l}\text { Stub columns at front sheared through. Sidewalls (brick) cracked. } \\
\text { Roof trusses dislodged. }\end{array}$ \\
\hline Hawke's Bay Farmer's Co-Op & 0.2 & 0.1 & Hair cracks in concrete on façade (structural damage). \\
\hline Webber's Buildings & 1 & 0.5 & No structural damage. \\
\hline Villa d'Este & 1 & 1 & Front facade (brick) fell out. Badly cracked. \\
\hline
\end{tabular}




\section{Bibliography}

Atimtany, E. \& Tuna, M.E., 1998, Erzincan Earthquake and After: Lessons Learned, Summary from Earthquake World Wide Conference.

Boyd, M.B., 1984, City of the Plains - A History of Hastings, Victoria University Press (for the Hastings City Council), pp.257-282.

Brodie, A, \& Harris, A.G., 1933, Damage To Buildings, The N.Z. Journal of Science and Technology.

Bruno, S., Decanini, L.D., Mollaili, F., 2000, Seismic Performance of Pre-Code Reinforced Concrete Buildings, Proceedings of the $12^{\text {th }}$ World Conference on Earthquake Engineering (2131), New Zealand Society for Earthquake Engineering, New Zealand.

Brunsdon, D., 1999, Study Group on Earthquake Risk Buildings 1998 Report, Proceedings of NZSEE Technical Conference, New Zealand Society for Earthquake Engineering, pp.100102.

Combescure, D., \& Pegon, P., 2000, Application of the Local to Global Approach to the Study of Infilled Frame Structures under Seismic Loading, Proceedings of the $12^{\text {th }}$ World Conference on Earthquake Engineering (0505), New Zealand Society for Earthquake Engineering, New Zealand.

Consolidated Report on Parametric Study, 1997, New Zealand National Society for Earthquake Engineering, Wellington, New Zealand (unpublished).

Dowrick, D.J., 1995-1998, personal notes on damage in Napier and Hastings in 1931 Hawkes Bay Earthquake (unpublished).

Dowrick, D.J., 1998 (a), Damage and Intensities in the Magnitude 7.81931 Hawke's Bay, New Zealand, Earthquake, Bulletin of the New Zealand National Society for Earthquake Engineering, pp.139-163, Vol.31, No.3. 
Dowrick, D.J., 1998 (b), Earthquake Risk for Property and People in New Zealand, Proceedings of the New Zealand National Society for Earthquake Engineering Technical Conference, pp.43-50.

Dowrick, D.J., Rhoades, D.A., Babor, J., Beetham, R.D., 1995, Damage Ratios for Houses and Microzoning Effects in Napier in the Magnitude 7.8 Hawke's Bay, New Zealand Earthquake of 1931, Bulletin of the New Zealand National Society for Earthquake Engineering, pp.134-145, Vol.28, No.2.

Dowrick, D.J., \& Sritharan, S., 1993, Attenuation of Peak Ground Accelerations in Some Recent New Zealand Earthquakes, Bulletin of the New Zealand National Society for Earthquake Engineering, pp.3-13, Vol.26, No.1.

Dowrick, D.J., \& Smith, E.C.G., 1990, Surface Wave Magnitudes of Some New Zealand Earthquakes 1901-1988, Bulletin of the New Zealand National Society for Earthquake Engineering, pp.198-210, Vol.23, No.3.

Dowrick, D. J., 1987, Earthquake Resistant Design for Engineers and Architects, Wiley, New York.

Fardis, M.N., 2000, Design Provisions for Masonry-Infilled RC Frames, Proceedings of the $12^{\text {th }}$ World Conference on Earthquake Engineering (2553), New Zealand Society for Earthquake Engineering, New Zealand.

FEMA-NEHRP Guidelines for the Seismic Rehabilitation of Buildings, 1997, Federal Emergency Management Authority, Publications 273/274.

Glogau, O.A., 1980, Section G: Low Rise Reinforced Concrete Buildings of Limited Ductility, Bulletin of the New Zealand National Society for Earthquake Engineering, pp.182193, Vol.13, No.2.

Hawke's Bay "Before" and "After" - The Great Earthquake of 1931, An Historical Record, 1931, The Daily Telegraph Co. Ltd., New Zealand. 
Jain, S.K., \& Murty, C.V.P., 2000, Beneficial Influence of Masonry Infill Walls on Seismic Performance of RC Frame Buildings, Proceedings of the $12^{\text {th }}$ World Conference on Earthquake Engineering (1790), New Zealand Society for Earthquake Engineering, New Zealand.

Kappos, A.J., \& Ellul, F., 2000, Seismic Design and Performance Assessment of Masonry Infilled R/C Frames, Proceedings of the $12^{\text {th }}$ World Conference on Earthquake Engineering (0989), New Zealand Society for Earthquake Engineering, New Zealand.

Lafuente, M., Molina, A., Genatios, C., 2000, Seismic-Resistant Behavior of Minor Reinforced Concrete Frames with Masonry Infill Walls, Proceedings of the $12^{\text {th }}$ World Conference on Earthquake Engineering (0974), New Zealand Society for Earthquake Engineering, New Zealand.

McVerry, G.H., Zhao, J.X., Abrahamson, N.A., Somerville, P.G., 2000, Crustal and subduction zone attenuation relations for New Zealand earthquakes, Proceedings of the $12^{\text {th }}$ World Conference on Earthquake Engineering (1834), New Zealand Society for Earthquake Engineering, New Zealand.

Mitchell, A.S., 1931, The Effects of Earthquakes on Buildings and Structures, NZIA Journal, pp.111-117.

NZS4203: 1992 Vol.1, Code of Practice for General Structural Design and Design Loadings for Buildings, Standards New Zealand, Wellington, New Zealand.

NZS4230: 1990, Code of practice for the design of masonry structures, Standards New Zealand, Wellington, New Zealand

Park, R., 1981, Review of Code Developments for Earthquake Resistant Design of Concrete Structures in New Zealand, Bulletin of the New Zealand National Society for Earthquake Engineering, pp.177-208, Vol.14, No.4.

Sahlin, S., 1971, Structural Masonry, Prentice-Hall, United Kingdom. 
Sritharan, S., \& Dowrick, D.J., 1995, Response of Low-Rise Buildings to Moderate Ground Shaking, Particularly the May 1990 Weber Earthquake, Bulletin of the New Zealand National Society for Earthquake Engineering, pp.205-221, Vol.27, No.3.

Stirling, M., McVerry, G., Berryman, K., McGinty, P., Villamor, P., Van Dissen, R., Dowrick, D., Cousins, J., 2000, Probabilistic seismic hazard assessment of New Zealand, Client Report 1999/53, prepared for Earthquake Commission Research Foundation, Institute of Geological and Nuclear Sciences Ltd, Lower Hutt, New Zealand.

The Assessment and Improvement of the Structural Performance of Earthquake Risk Buildings (Draft for General Release), 1996, New Zealand National Society for Earthquake Engineering, Wellington, New Zealand, (unpublished).

\section{Other Resources}

Alexander Turnbull Library: Photos 29461/2, 48051/2, 48481/2, 1545591/2, C21788, EP689, F316101/2, G171941/4, G483381/2, N1, N37, N47, N58, P5, P10 (plus five others with no reference).

Street maps of Napier (1916), Hastings (1925) and Port Ahuriri (1924), The Council of The Fire Underwriters' Associations of New Zealand, New Zealand (Source: Dowrick, 1998).

Stones Non-Domestic Street Directory, 1930, New Zealand (Source: Dowrick, 1998).

Wellington City Council Archives. 